$$
\begin{gathered}
\text { UNIVERSIDADE DE SÃO PAULO } \\
\text { MUSEU DE ARQUEOLOGIA E ETNOLOGIA } \\
\text { PROGRAMA DE PÓS-GRADUAÇÃO EM ARQUEOLOGIA }
\end{gathered}
$$

ELAINE CRISTINA CARVALHO DA SILVA

Formações Sociais e Organização Territorial no NO Peninsular: a integração no mundo romano durante o Alto Império

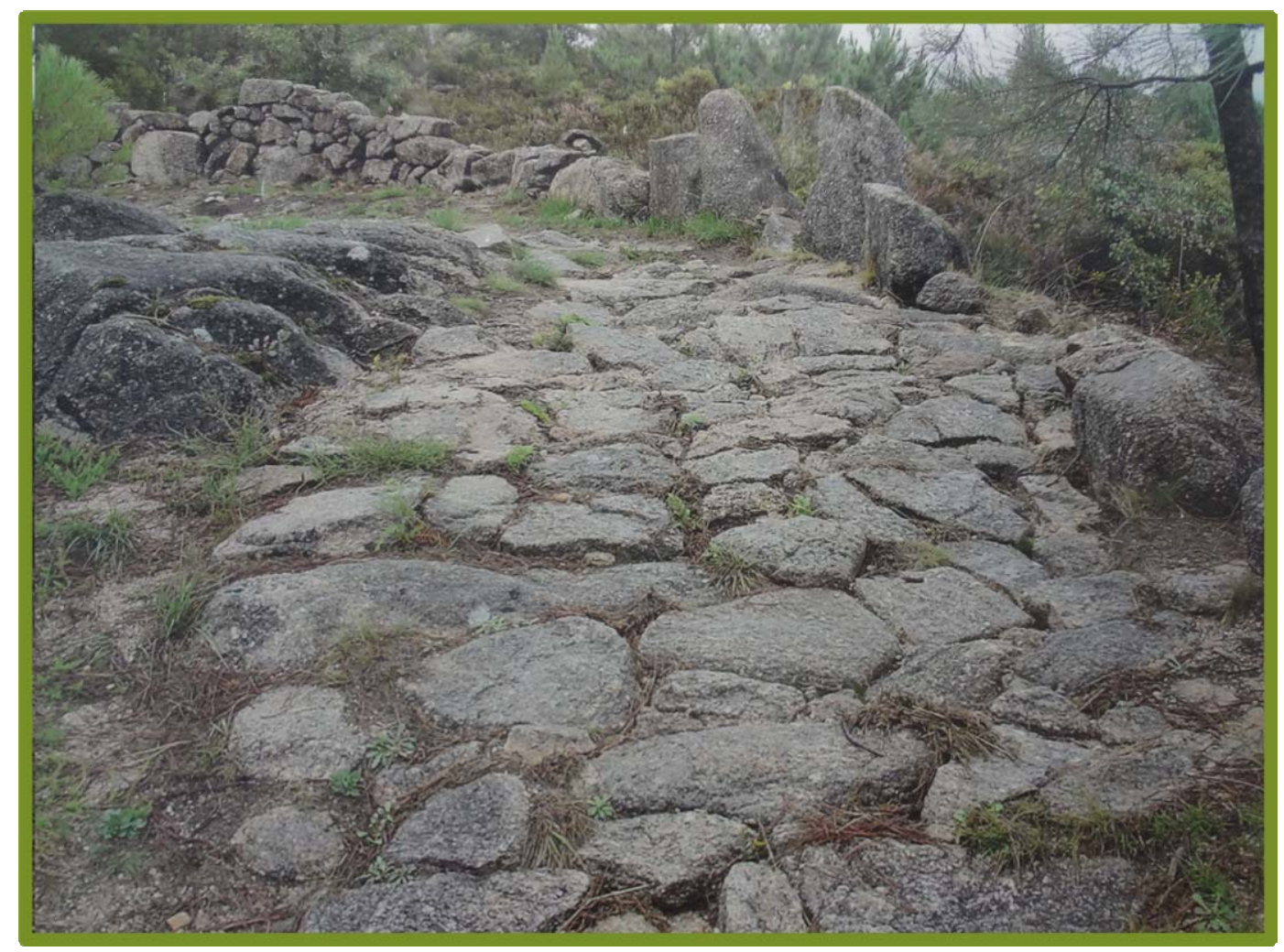

Via Nova (Geira)

São Paulo 


\title{
Formações Sociais e Organização Territorial no NO Peninsular: a integração no mundo romano durante o Alto Império
}

\author{
TESE APRESENTADA AO PROGRAMA DE PÓS- \\ GRADUAÇÃO EM ARQUEOLOGIA DO MUSEU DE \\ ARQUEOLOGIA E ETNOLOGIA DA UNIVERSIDADE DE \\ SÃO PAULO PARA OBTENÇÃO DO TÍTULO DE DOUTORA \\ EM ARQUEOLOGIA
}

DEZEMBRO DE 2016

Área de Concentração: Arqueologia

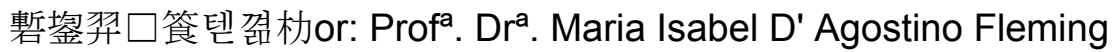

Linha de Pesquisa: 02 - Espaço, Sociedade e Processos de Formação do Registro Arqueológico

Versão revisada

A versão original encontra-se na Biblioteca do MAE/USP

São Paulo

2016 
À memória de minha mãe,

Maria José Carvalho da Silva 


\section{RESUMO}

\section{Formações Sociais e Organização Territorial no NO Peninsular: a integração no mundo romano durante o Alto Império}

No presente trabalho, optou-se por adotar preceitos teóricos e metodológicos fundamentados nos princípios da interdisciplinaridade, a fim de melhor compreender os processos que resultaram na construção da Paisagem em estudo, a partir da lógica da rede viária romana do Noroeste Peninsular, pois são grandes eixos com uma influência persistente na morfologia histórica.

Reconhecendo, assim, que sua incorporação na análise arqueológica pressupõe sua abordagem como um sistema complexo e dinâmico no qual diferentes fatores naturais, culturais, materiais, econômicos, ideológicos e políticos - interagem e evoluem conjuntamente. Daí a opção pela perspectiva metodológica denominada Arqueologia da Paisagem vinculada ao ferramental Geotecnológico.

É nesse sentido que aplicamos uma metodologia de estudo utilizando o ferramental geotecnológico interagindo com outras fontes disponíveis, tais como: fontes textuais, itinerários, epigrafia, miliários, pontes, dados ambientais e arqueológicos. As geotecnologias permitem integrar o conhecimento geográfico com o conhecimento arqueológico e historiográfico. Esses aspectos viabilizam uma análise mais integrada das redes viárias antigas, em particular dos itinerários que ligavam as três capitais conventuais do Noroeste Peninsular Romano fundadas por Augusto: Bracara Augusta, Lucus Augusti e Asturica Augusta.

A partir da análise de cálculos de rotas ótimas foi possível observar que a lógica de mobilidade da rede viária romana, iniciada com a reorganização administrativa implementada por Augusto, priorizava ligações entre núcleos urbanos localizados em pontos estratégicos de controle do território e de tráfego de mercadorias. Dessa forma, as vias, além de estabelecerem ligações, a escalas variadas, entre os principais aglomerados populacionais, também garantiam a defesa e afirmação do poder de Roma sobre os territórios conquistados.

Palavras-chave: Noroeste Peninsular, rede viária, Paisagem, Itinerário de Antonino, rotas ótimas. 


\section{SUMMARY}

\section{Social Formations and Territorial Organization in the Peninsular NW: integration in the Roman world during the High Empire}

In the present work, it was decided to adopt theoretical and methodological precepts based on the principles of interdisciplinarity, in order to better understand the processes that resulted in the construction of the Landscape under study, based on the logic of the Roman road network of the North-West Peninsular, axes with a persistent influence on historical morphology.

Therefore, it is important to note that this is a complex and dynamic system in which different factors - natural, cultural, material, economic, ideological and political interact and evolve together. Hence the option for the methodological perspective called Landscape Archeology linked to the Geotechnological tooling.

It is in this sense that we apply a methodology of study using the geotechnical tooling interacting with other available sources, such as: textual sources, itineraries, epigraphy, miliaries, bridges, environmental and archaeological data. Geotechnologies allow the integration of geographic knowledge with archaeological and historiographic knowledge. These aspects make possible a more integrated analysis of the old road networks, in particular the itineraries that linked the three conventual capitals of the Roman Northwest founded by Augustus: Bracara Augusta, Lucus Augusti and Asturica Augusta.

From the analysis of optimum route calculations, it was possible to observe that the mobility logic of the Roman road network, initiated with the administrative reorganization implemented by Augustus, prioritized links between urban nuclei located at strategic points of territory control and traffic of goods. In this way, the routes, other establishing connections, at different scales, between the main population groups, also guaranteed, the defense and affirmation of the power of Rome over the conquered territories.

Key words: Peninsular Northwest, road network, Landscape, Antonino's Itinerary, Optimal Pathways/Optimal Routes. 
Primeiramente, gostaria de expressar minha gratidão à $\operatorname{Prof}^{a} \operatorname{Dr}^{a}$ Maria Isabel D'Agostino Fleming, que generosamente aceitou ser minha orientadora e, paciente e incansavelmente, ajudou a elaborar e concluir esta tese, apesar de todos os percalços e dificuldades pelos quais passamos ao longo desses anos. Mabel, esta pesquisa não seria possível sem o seu apoio e carinho. Devo-lhe muito mais do que a confiança depositada em mim. Muito obrigada!

Sou extremamente grata pelas sugestões e materiais disponibilizados pela Profa. Dra. Helena Paula Abreu de Carvalho, da Unidade de Arqueologia da Universidade do Minho, que gentilmente me acolheu em Braga e nas escavações em Vieira do Minho. Sua ajuda foi fundamental para colocar em perspectiva as informações e, principalmente, as dúvidas encontradas no estudo do Noroeste Peninsular.

Agradeço, também, o Prof. Dr. Francisco Azevedo Mendes, Eurico Loureiro e Carla Xavier (CITCEM, Universidade do Minho), pelo material gentilmente disponibilizado.

Agradeço à minha Banca de Qualificação, formada pelas Profas. Dras. Helena Paula Abreu de Carvalho (UAUM) e Maria Cristina Kormikiari Passos (MAE-USP), pela leitura criteriosa e conselhos recebidos na Qualificação.

Com relação à elaboração das plantas, agradeço à equipe de Geoprocessamento da JGP Consultoria e Participações Ltda: Tadeu Gasparetto, Edson Alves Filho, José Celso Paiva, e Marcos Peixoto. Sobretudo, imprescindível, foi a colaboração de Ricardo Ignácio Fogaroli. Muito obrigada Ricardo, pela paciência e apoio nos momentos mais tensos.

Em Cascais, agradeço pelo abrigo ofertado pelos amigos Andréa e Joaquim Moreira, e Camila e Maycon Souza.

Pelo apoio, revisões, suporte nas horas de angústia, agradeço à incansável amiga Irmina Doneux Santos.

Aos colegas do Laboratório de Arqueologia Romana Provincial - LARP/USP, agradeço a oportunidade e apoio pela viagem à Portugal, em 2012, para levantamento de dados de campo e material bibliográfico. Em especial, Irmininha, minha companheira de pesquisas em Portugal.

Provavelmente, deixarei de citar pessoas que me ajudaram durante esses anos, mas não posso deixar de agradecer aos colegas que trabalham na Biblioteca do MAE, pois sempre atenderam com gentileza e presteza às minhas solicitações. $E$ também ao pessoal da Seção Acadêmica, que estava lá quando precisei.

À minha família, agradeço a paciência e os cuidados de meu pai, José Roberto da Silva, sobretudo nos momentos finais.

Ao meu lado está, desde sempre, Teicianne Miranda de Freitas. Nada teria sido possível sem o seu apoio e companheirismo. 
Por fim, sou grata à CAPES, que financiou a pesquisa com uma bolsa de doutorado; e à FAPESP, pela ajuda financeira para o levantamento de campo em Portugal para o Banco de Dados do Laboratório de Arqueologia Romana Provincial LARP/USP. E ao Programa de Mobilidade Internacional do Banco Santander (julho e agosto de 2013).

Se deixei de mencionar alguém, peço que me desculpem pelo esquecimento, apenas momentâneo; a gratidão, entretanto, será eterna. 


\section{Sumário}

INTRODUÇÃO

CAPÍTULO 1. PRESSUPOSTOS TEÓRICO-METODOLÓGICOS E PONTOS DE

PARTIDA

1.1. Enquadramento Teórico - Espaço, Território e Paisagem ................................. 13

1.2. Enquadramento Teórico - Distintos enfoques, uma mesma Arqueologia ............ 26

1.3. Enquadramento Metodológico - As Geotecnologias na interpretação da paisagem arqueológica

1.4. Atual situação dos estudos sobre a "Romanização" do Noroeste Peninsular uma aproximação pós-colonialista.

CAPÍTULO 2. CONTEXTUALIZAÇÃO HISTÓRICA - A CONQUISTA .............................. 53

CAPÍTULO 3. ORGANIZAÇÃO ADMINISTRATIVA E TERRITORIAL ............................ 89

3.1. O Noroeste Pré-romano: Síntese Interpretativa.......................................... 89

3.2 A Consolidação do Poder Romano no Noroeste ........................................... 103

3.3 A Política Urbana de Augusto ................................................................ 111

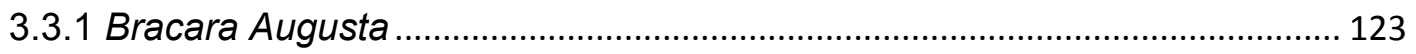

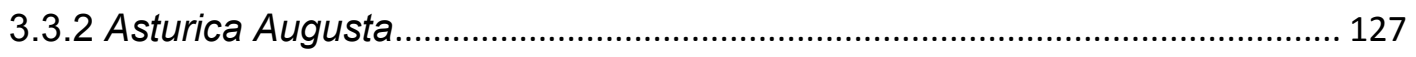

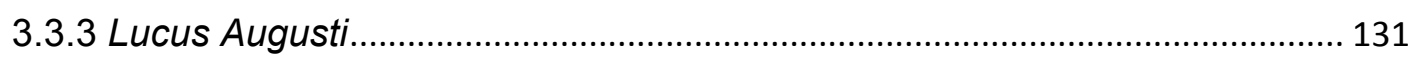

CAPÍTULO 4. A LÓGICA DA REDE VIÁRIA ROMANA NO NOROESTE ..................... 141

4.1 A Rede Viária do Noroeste Peninsular .................................................... 141

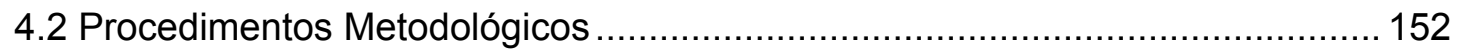

4.2.1 Descrição do projeto SIG: Cálculo de caminhos ótimos ................................ 155

4.3 Resultados das modelações dos caminhos ótimos ....................................... 160

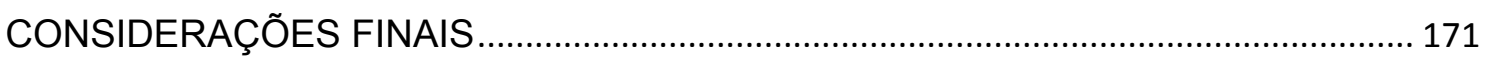

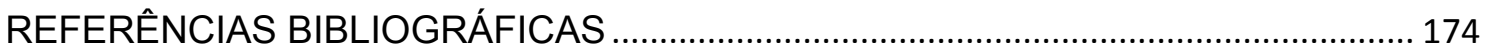

Anexo 1 - Modelo Digital do Terreno: Vias XVII, XVIII e XIX do Itinerário de Antonino

Anexo 2 - Modelo Digital do Terreno: Cálculo de caminho ótimo das Vias XVII, XVIII e $\mathrm{XIX}$ 
Sempre chegamos ao sítio aonde nos esperam.

(O Livro dos Itinerários).

José Saramago,

"A viagem do elefante", 2008.

Carpe diem, viator. 


\section{INTRODUÇÃO}

A presente tese de doutorado, desenvolvida no Programa de Pós-Graduação em Arqueologia do Museu de Arqueologia e Etnologia da Universidade de São Paulo, tem como objetivo principal apresentar a conquista e organização territorial romanas do Noroeste da Península lbérica a partir das pré-existências regionais, tão particulares em se tratando da região em estudo. Para tal, adotamos preceitos teóricos e métodológicos fundamentados nos princípios da interdisciplinaridade para compreender os processos que resultaram na construção da Paisagem em estudo, a partir do estudo da lógica da construção dos traçados das vias romanas conhecidas no NO Penínsular.

O ponto de partida lógico são as três capitais conventuais do NO romano, Bracara Augusta, Lucus Augusti e Asturica Augusta, de fundações da época do imperador Augusto.

Foram utilizadas, na pesquisa de campo, as ferramentas próprias das Geotecnologias (ou tecnologias espaciais), que tornaram possível perceber que as vias romanas XVII, XVIII e XIX, descritas no Itinerário de Antonino, foram estabelecidas a partir dos eixos de circulação pré-existentes que, por sua vez, foram determinados pelos condicionantes geomorfológicos e topográficos.

Os elementos de registro arqueológico utilizados na construção do modelo de análise espacial foram os miliários romanos conhecidos, as pontes romanas e os vestígios de calçadas (ou seja, o que permaneceu do registro em solo das vias), os topônimos relacionados a esses caminhos, e os vestígios arqueológicos e históricos que pudessem fazer referência a lugares de habitação de época romana relacionados às vias, especificamente os mansios, estações viárias de suporte aos viajantes.

No Capítulo 1, "Pressupostos Teórico-Metodológicos e Pontos de Partida", apresentamos as questões relacionadas aos estudos da Arqueologia da Paisagem. Foram utilizados preceitos teóricos e metodológicos fundamentados nos princípios da interdisciplinaridade - principalmente na interação da Geografia, Ecologia, História e Arqueologia - a fim de melhor compreender os processos que resultaram na construção da Paisagem do Noroeste Peninsular Romano, a partir de suas três capitais políticas: Bracara Augusta, Lucus Augusti e Asturica Augusta.

$\mathrm{Na}$ análise arqueológica, um sistema complexo e dinâmico no qual diferentes fatores - naturais, culturais, materiais, econômicos, ideológicos e políticos - interagem e evoluem conjuntamente, a opção pela perspectiva metodológica denominada Arqueologia da Paisagem, vinculada ao ferramental Geotecnológico, é imprescindível para o estudo aqui desenvolvido.

As geotecnologias permitem integrar o conhecimento geográfico com o conhecimento arqueológico e historiográfico. Além do mais, a disponibilidade de cartografia em formato digital avançou de forma surpreendente nos últimos anos, principalmente em território espanhol. Todos esses aspectos viabilizaram uma análise integrada das redes viárias antigas, em particular dos itinerários que ligavam o Noroeste Peninsular Romano, pois são grandes eixos com uma influência persistente na morfologia histórica e comprovam a capacidade romana de transformação da paisagem, tanto rural quanto urbana. 
Objetivou-se nessa pesquisa, portanto, estudar a lógica da criação de uma rede viária de comunicação que uniu os núcleos urbanos romanos entre si e/ou com lugares de interesse estratégico ou econômico para a administração romana, como, por exemplo, as aglomerações secundárias que estavam localizadas em nós viários e proporcionou uma efetiva integração da região.

O Capítulo 2, "Contextualização Histórica", apresenta uma compilação da conquista romana do NO Peninsular utilizando, como fonte, os textos históricos e os registros arqueológicos relacionados à paisagem. A contextualização buscou apresentar a questão da conquista vinculada aos condicionantes geomorfológicos e topográficos.

O Capítulo 3, "Organização Administrativa e Territorial", apresenta uma síntese do mundo pré-romano do NO Peninsular, o qual era caracterizado pela paisagem fortificada, os chamados castros. Em seguida, tratamos de como se deu a consolidação do poder romano na região a partir das fontes disponíveis (históricas e, principalmente, arqueológicas e epigráficas). Nesse ponto, valoriza-se o papel de Augusto no processo de reorganização administrativa e territorial do Noroeste Peninsular.

Será dentro dessa perspectiva que Augusto empreenderá uma política de integração do Noroeste ao império romano, que terá como consequência a profunda modificação das estruturas existentes. E uma de suas ações foi implantar redes viárias, que articulariam todo o território, garantindo, dessa forma, uma articulação territorial que proporcionou o funcionamento eficaz desse sistema. As vias de comunicação, quase sempre, constituem pontos de passagem obrigatórios, espaços de confluência e cruzamento de vias.

Mas uma das principais ações de Augusto foi efetuar a subdivisão do império em províncias o que implica em outros níveis hierárquicos de organização, entre os quais se destacam os Conventus luridici e as Civitates.

Por fim, no Capítulo 4, "A Lógica da Rede Viária Romana no Noroeste", através de uma análise de escala espacial, que parte de elementos básicos na organização do território do Noroeste Peninsular, e com o recurso do ferramental SIG, realizamos uma análise de como o poder romano articulou o território, estabelecendo diferentes vias de comunicação que uniram os principais núcleos romanos entre si: ou com locais de interesse estratégico ou econômico para a administração imperial. O ponto de partida da articulação romana da rede viária foram as três capitais conventuais do NO romano fundadas por Augusto, as atuais cidades de Braga (Portugal), Lugo e Astorga (Espanha).

O objetivo desse trabalho foi demonstrar, a partir do estudo das relações entre redes de caminhos, povoamento e território, uma abordagem experimental através da utilização de ferramentas geotecnológicas na pesquisa arqueológica, o qual propomos um exemplo metodológico de aplicação de diferentes variáveis para o cálculo de rotas ótimas para o território do Noroeste Peninsular.

O que Roma fornece são traçados mais amplos e encaixados em um curso mais racional, pavimentos mais acessíveis, pontes e outros meios para superar as canais fluviais e estações viárias ou locais de descanso (mansiones), estrategicamente localizadas, para permitir o descanso nos percursos de longa distância. 
Por fim, a "Conclusão" trata da aplicação do modelo de "caminhos de deslocamento ótimos" (ou "rotas ótimas") através da utilização do ferramental geotecnológico, buscando compreender a lógica de mobilidade da rede viária romana, se as vias foram estabelecidas para unir, de forma mais prática e direta possível, as três capitais conventuais.

Os resultados obtidos demonstraram que os romanos levaram em conta a lógica de caminhos ótimos de mobilidade ou deslocamento entre os diversos nós viários, entretanto não o fizeram somente tendo em conta a ligação entre as capitais conventuais, mas sim com os núcleos urbanos "secundários", relacionados a lugares estratégicos para os deslocamentos, os nós viários, onde as mansiones (estações viárias que funcionavam como estalagens) estavam situadas. Ou seja, para o controle territorial relacionado ao tráfego de mercadorias e pessoas e os deslocamentos dos exércitos. 


\section{CAPÍTULO 1. PRESSUPOSTOS TEÓRICO-METODOLÓGICOS E PONTOS DE PARTIDA}

\subsection{Enquadramento Teórico - Espaço, Território e Paisagem}

Cada fenômeno estudado pelos arqueólogos ocorre em uma dimensão espaçotemporal. Mas, como ciência social que é, "a Arqueologia almeja ultrapassar certas abordagens funcionalistas e a simples busca pelo onde e quando determinados grupos desenvolveram suas diversas atividades" (SILVA, 2006: 16). Para isso, tornamse necessários, além da utilização de informação espacial, também diversos estudos e escalas de aplicação para que a Arqueologia possa se aproximar dos sujeitos e interpretar o sentido dos vestígios analisados em um complexo contexto num determinado espaço e tempo. Basta pensar, por exemplo, no estudo do povoamento de certa região e nos diversos critérios ambientais, econômicos, políticos e culturais que condicionaram essa ocupação.

Nesses estudos, a Arqueologia sempre se valeu não só de suas próprias metodologias como, também, de numerosas contribuições de outros campos científicos tradicionalmente voltados às análises espaciais, como a Geografia, a Geologia e a Ecologia. Mas, o que geralmente se percebe dessa aproximação da Arqueologia com outras disciplinas é a introdução de conceitos e novas propostas metodológicas que parecem ter sido apropriados superficialmente sem ter havido debates epistemológicos mais frequentes.

No presente trabalho, optou-se por adotar preceitos teóricos e metodológicos fundamentados nos princípios da interdisciplinaridade, a fim de melhor compreender os processos que resultaram na construção da Paisagem em estudo, o Noroeste Peninsular Romano, a partir de suas três capitais políticas: Bracara Augusta, Lucus Augusti e Asturica Augusta. Reconhecendo, assim, que sua incorporação na análise arqueológica pressupõe sua abordagem como um sistema complexo e dinâmico no qual diferentes fatores - naturais, culturais, materiais, econômicos, ideológicos e políticos - interagem e evoluem conjuntamente. Daí a opção pela perspectiva metodológica denominada Arqueologia da Paisagem vinculada ao ferramental Geotecnológico.

De acordo com Milton Santos (1999: 62),

[...] os mesmos objetos podem dialogar com as mais diversas disciplinas [...]. A questão que se coloca é, pois, sobretudo, uma questão de método, isto é, da construção de um sistema intelectual que permita, analiticamente, abordar uma realidade, a partir de um ponto de vista.

O interesse pela relação entre espaço e sociedade faz parte tanto da Geografia quanto da Arqueologia e, por conseguinte, a utilização de conceitos e categorias geográficas de análise espacial, como espaço, paisagem, território, região e lugar, são 
exemplos de áreas de estudo privilegiadas pelos geógrafos e arqueólogos em suas práxis.

A Geografia se expressou, e ainda se expressa, ancorada nesse conjunto de conceitos e categorias ${ }^{1}$ que, muitas vezes, são considerados como equivalentes, a exemplo do uso da categoria de espaço geográfico como equivalente ao conceito de paisagem, entre outros. Percebe-se, entretanto, que essas concepções expressam níveis de abstração diferenciados e, por consequência, possibilidades operacionais também diferenciadas.

O desenvolvimento dessa pesquisa corrobora o que Gomes (2002: 292) diz:

[...] podemos conceber que os objetos de investigação são construídos pelo tipo de questões a eles endereçadas, sendo estas questões que os conformam, os limitam, os criam, e não o inverso, como, por vezes, tendemos a imaginar.

Portanto, vale ressaltar que a intenção aqui não é estabelecer uma definição última para os conceitos e categorias geográficas de análise espacial. Todavia, para categorizar o espaço tem-se que trabalhar conceitos. O importante, entretanto, é que se tenha uma noção mínima do que seja cada um desses conceitos e categorias geográficas de análise espacial, de forma que não sejam utilizados indevidamente. Para tanto, optou-se por selecionar algumas definições que melhor se adaptam à presente pesquisa.

\section{Sobre o Espaço...}

Muitas perspectivas de análise têm sido propostas para compreender as transformações do espaço geográfico. O debate sobre ele é antigo e tomou vários caminhos de acordo com o pensamento da época, ou seja, relacionado ao contexto no qual estavam inseridos aqueles que "faziam" a Geografia.

Por muito tempo se tentou definir o que era esse espaço, mas pensado enquanto um objeto. E seu estudo, de uma maneira mais científica, se inicia associado à Matemática, através das percepções puras da Geometria: ponto, reta e plano.

Todas as ideologias de uma época pertencem a uma mesma mentalidade e o próprio conhecimento da sociedade é uma interpretação. No campo científico, essas ideologias se expressam em métodos diferentes. Assim, em meados do século XX começa a surgir certa desmaterialização do espaço e este começa a ser trabalhado não mais como algo empírico, mas como uma forma de se ver a realidade.

Douglas Santos, em sua obra A reinvenção do Espaço (2002), diz:

Se é possível considerar-se que tanto para a física quanto para a geografia a noção de espaço ultrapassa os limites da identificação do objeto e colocase como uma espécie de identidade epistêmica, é fato, também, que tanto

\footnotetext{
${ }^{1}$ Não é o objetivo nessa pesquisa aprofundar-se em uma discussão ontológica sobre conceitos e categorias geográficas de análise espacial. Entretanto, considero interessante apresentar uma visão objetiva sobre o assunto proferida em março de 2012 em uma das aulas da disciplina de pós-graduação da FFLCH/USP, "Formação Territorial e Teoria em Geografia Humana", ministrada pelo Professor Dr. Antonio Carlos Robert Moraes (Prof. Tonico): "Para se definir Categoria é preciso um livro; para se definir Conceito é preciso uma página ou duas; e para se definir Noção...nem paro para discutir, tomo como subtendida".
} 
uma quanto outra [...] está, no entanto, mais preocupada em descrevê-lo que, propriamente, em conceituá-lo. (SANTOS, 2002: 17).

Percebe-se que a Geografia trabalha com "algo", ou seja, o espaço como centro de interesse - que outros campos disciplinares também trabalham, mas de uma forma específica - e essa nova abordagem se dá a partir de determinadas posturas metodológicas. Então, pode-se dizer que o que define as várias ciências é a abordagem utilizada.

Portanto, a partir desse momento, a Geografia cessa de tentar buscar esse objeto e passa a definir claramente uma abordagem, rompendo, assim, com a ideia de um ente material, específico. Aquilo que era até então algo externo ao sujeito passa a ser visto a partir de uma realidade múltipla. Assim, há o surgimento de um ecletismo "consciente" de diversos enfoques metodológicos, levando a um maior diálogo entre eles. Quanto maior o número de enfoques sobre um mesmo assunto, melhor ele poderá ser trabalhado.

Douglas Santos (2002: 23), em sua reflexão sobre a construção de discursos sobre o espaço, continua:

O que pensamos de espaço jamais poderá ser compreendido sem que se reflita sobre o próprio movimento que cria, recria, nega e, pela superação, redefine a espacialidade dos próprios homens. Espaço e tempo [...] são, na verdade, redimensionados na medida em que as sociedades se redimensionam.

O espaço, enquanto categoria, é tão abundante de significados que se torna complicado querer expressá-lo. Entretanto, a perspectiva abordada no livro de Éric Dardel, intitulado O Homem e a Terra² (2011 [1952], exemplifica o tipo de indagação que vai além das análises propostas em relação ao objeto e ao caráter científico da Geografia, através do ponto de vista da fenomenologia ${ }^{3}$. É de Dardel o conceito geograficidade, que expressa a essência da relação Homem-Terra: "do ser-e-estar-nomundo".

Segundo aponta Jean-Marc Besse (2011: 120), o conceito de geograficidade de Dardel foi formulado a partir da noção de historicidade, que "implica na consciência que o ser humano tem de sua situação irremediavelmente temporal. [...] Essa compreensão histórica do mundo vai outorgar a presença ao Existir".

Portanto, ser-e-estar-no-mundo expressa uma relação concreta entre o homem e a Terra que resulta em formas concretas de viver. Observa-se, assim, que a sociedade tem uma espacialidade.

\footnotetext{
2 "L' Homme et la Terre", considerada a obra fundadora de uma geografia fenomenológica, foi publicada em Paris em 1952 na coleção "Nouvelle Encyclopedie Philosophique", dirigida por E. Bréhier. A versão brasileira foi publicada em 2011 pela Editora Perspectiva, com tradução de Werther Holzer (UFF).

3 Segundo a definição de Robert Audi (adaptada, 1999: 665), a Fenomenologia é uma escola filosófica cujo propósito principal é o estudo dos fenômenos da experiência humana subjetiva com base em uma rejeição de qualquer consideração da realidade objetiva. Os fenômenos estudados são, principalmente, aqueles relacionados aos atos de consciência, cognitivos e de percepção, embora também aqueles de avaliação e apreciação estética.
} 
Essa reflexão feita por Dardel vai ao encontro da abordagem aplicada pelo grupo de pesquisa galego "Arqueología del Paisaje y Paisajes Culturales", do Instituto de Ciencias del Patrimonio, do Consejo Superior de Investigaciones Científicas (Incipit, $\mathrm{CSIC})^{4}$.

Segundo o investigador do Incipit, o arqueólogo Felipe Criado-Boado (2013: 03),

[...] Ser-en-el-mundo es estar-en-el-mundo. Pero se puede estar de múltiples formas, tanto como formas de ser hay distintas.

Ahora bien, lo que conduce del hábito del ser al hábitat o morada del estar es la forma de concebir o pensar el espacio: la transformación del hábito en hábitat se basa en y se edifica sobre una cierta concepción del espacio. Ese impacto del espacio pensado se materializa por igual en el hábitat comprendido como entorno o como casa, como paisaje o como arquitectura.

Logo na introdução de O Homem e a Terra (2011 [1952]: 2), Dardel apresenta uma oposição entre espaço geométrico e espaço geográfico:

O espaço geométrico é homogêneo, uniforme, neutro. Planície ou montanha, oceano ou selva equatorial, o espaço geográfico é feito de espaços diferenciados. O relevo, o céu, a flora, a mão do homem dá a cada lugar uma singularidade em seu aspecto. O espaço geográfico é único; ele tem nome próprio: Paris, Champagne, Saara, Mediterrâneo.

A geometria opera sobre um espaço abstrato, vazio de todo conteúdo, disponível para todas as combinações. O espaço geográfico tem um horizonte, uma modelagem, cor, densidade. Ele é sólido, líquido ou aéreo, largo ou estreito: ele limita e resiste.

Na primeira parte de O Homem e a Terra, Dardel apresenta cada um dos espaços diferenciados do espaço geográfico, quais sejam: espaço aquático, espaço telúrico, espaço aéreo, espaço construído. De acordo com Jean-Marc Besse (2006: 87), "o que Dardel visa, pela análise destes diferentes espaços que são no fundo dimensões de sentidos, é ilustrar a tese fundamental segundo a qual o espaço geográfico é, antes de qualquer outra designação, um espaço material".

$\mathrm{Na}$ análise do espaço construído, Dardel diz que (2011 [1952]: 7-8):

Por toda parte o espaço geográfico é talhado na matéria ou diluído em uma substância móvel ou invisível. [...] O espaço "puro" do geógrafo não é o espaço abstrato do geômetra: é o azul do céu, fronteira entre o invisível; é o vazio do deserto, espaço para a morte; é o espaço glacial da banquisa, o espaço tórrido do Turquestão, o espaço lúgubre da landa sob a tempestade. Há ainda algo aqui, uma extensão a atravessar ou a evitar, a areia que fustiga, as fornalhas naturais, o vento que uiva. Uma resistência ou um ataque da Terra. Mesmo o silêncio ou a desolação, é também uma realidade do espaço geográfico, uma realidade que oprime, uma realidade que exclui.

\footnotetext{
4 Antigo Laboratorio de Patrimonio (LaPa) da Universidade de Santiago de Compostela, Espanha (http://www.incipit.csic.es/es/Default.aspx).
} 
Dessa forma, na perspectiva de Dardel, "o espaço geográfico é, de início, um espaço concreto, espaço praticado, vivido e percebido, um espaço da vida" (BESSE, 2006: 87).

Criado-Boado (2013: 04), em sua reflexão sobre o espaço expressa:

Pero, ¿qué es el espacio? Tenemos que ser capaces de diferenciar la realidad de su concepto. Fisicamente existe algo que es el espacio; pero esa existencia es comprehendida y ordenada de formas dispares por las diferentes culturas.

En cualquiera de ellas sin embargo el espacio lo crea la mirada, lo aprehende la visión, lo dimensiona el movimiento, lo piensa la razón. Si el ser social piensa el espacio, éste se hace forma y la forma es visible, entonces todo lo visible es racional y simbólico. Este es uno de los principios que nos permiten en la práctica estudiar el espacio y sus objetivaciones, desde el paisaje a la cultura material. Para ver tenemos que, sucesiva pero instantáneamente, mirar-saber-pensar. De este modo, el paisaje (la arquitectura o, incluso, la cultura material) involucra modos de saber, de mirar, de ver, de pensar. También modos de andar y transitar. Una vez pensado, el espacio se percibe, construye y comprehende al ver $y$ al andar.

Las formas que el espacio adopta, el mismo patrón de variación diacrónico de aquellas, son el resultado de una doble tensión espacial. Por una parte entre el círculo y el cuadrado, entre las líneas curvas y axiales, entre la esfera y el cubo. Y por otra entre la línea horizontal y la vertical, entre la extensión en el plano y la conquista del aire.

A partir da correlação com esse último parágrafo, é interessante apresentar outro autor que aborda o estudo do espaço geográfico: Roger Brunet. Em sua obra Le Déchiffrement du Monde: théorie et pratique de la géographie (2001), Brunet apresenta propostas de estruturação conceitual e metodológica para a Geografia, nas quais se inclui o mapa. Por conseguinte, uma de suas principais proposições é a coremática, ou modelização gráfica.

A coremática tem como propósito analisar os resultados da interação entre os diferentes atores na produção do espaço geográfico. Esses sistemas geográficos que resultam dessa interação produzem figuras geográficas, que "são expressão de estruturas elementares pelas quais passa o domínio do espaço" (BRUNET, 2001: 195 apud GIRARD, 2008: 72-73). Essas informações geográficas definem o conjunto de entidades geográficas e são aferidas geométrica e topologicamente ${ }^{5}$.

Essas figuras geográficas são denominadas por Brunet de coremas (chorème), do grego Khóra ${ }^{6}$, termo que designa espaço. As coremas são distinguidas por algumas figuras chave, representadas a partir de quatro elementos de base: ponto, linha, área e rede. As coremas, portanto, representam as estruturas do espaço dos homens. A

\footnotetext{
${ }^{5} \mathrm{~A}$ topologia define a relação existente entre os objetos no espaço.

${ }^{6}$ Segundo definição apresentada no glossário do Laboratório de Estudos sobre a Cidade Antiga - Labeca,

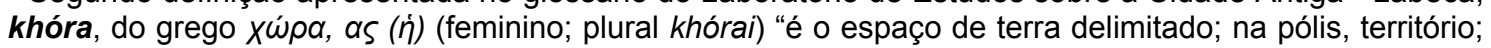
o campo em oposição à área urbana, local onde eram realizadas atividades produtivas; abrigava, por exemplo, fazendolas, santuários extra-urbanos". Disponível em: http://labeca.mae.usp.br/pt-br/glossary/
} 
Figura 1.1.a, abaixo, apresenta os 28 modelos que representam as coremas de Brunet.

Figura 1.1.a

Coremas propostas por Brunet

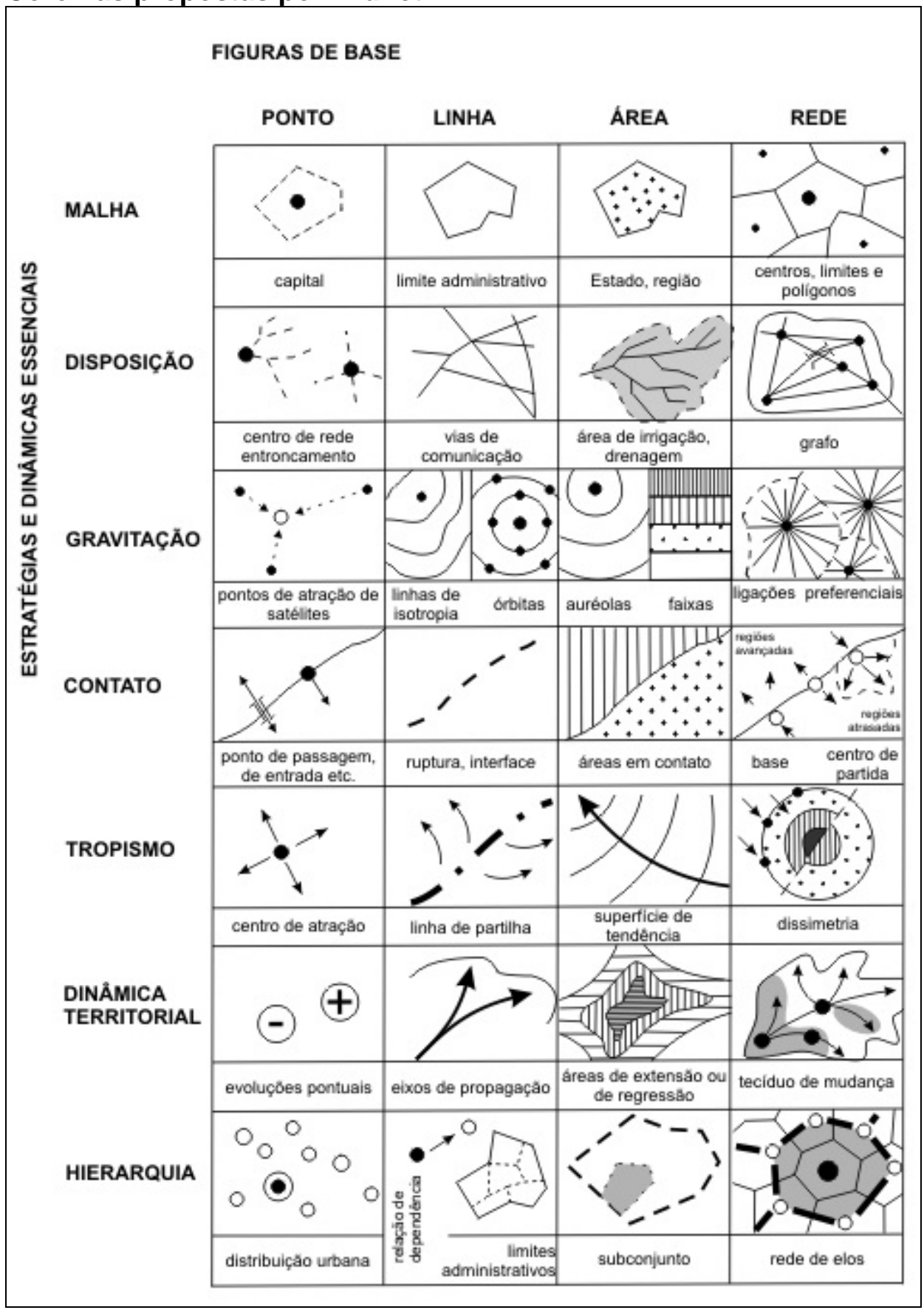

Fonte: Adaptado e traduzido de Brunet (2001) por Girardi (2008).

Para Brunet (2001: 15 apud GIRARD, 2008: 34), "o espaço geográfico não é nem o espaço abstrato, homogêneo, isotrópico, contínuo e infinito das teorias econômicas, nem o espaço físico (dito natural)". Este deve ser visto "como produto, atravessado por campos de forças, constitutivamente anisotrópico e mesmo fundamentalmente dessimétrico". 
Ainda para Brunet (2001: 20 apud GIRARD, 2008: 34), o conceito de produção do espaço não deve ser confundido com o conceito de produção no sentido econômico, mas deve ser entendido em um sentido amplo, filosófico: "a humanidade produz sentido, pensamento, obras e eventos da mesma forma que bens e mercadorias. Produz também espaço".

Em sua análise, Brunet apresenta os cinco domínios nos quais as sociedades atuam no espaço: habitação (abrigar, alojar), apropriação (possuir), exploração (produzir), trocas (comunicar) e organização (gerir). É a partir desses domínios que a sociedade produz o espaço (GIRARD, 2008: 34). A relação sociedade-espaço se traduz em um universo de relações sociais onde vários processos estão presentes. Dessa forma, é na produção do espaço, ou seja, na interação entre os diversos atores que agem no espaço, que as figuras geográficas de Brunet são criadas.

\section{Sobre o Território...}

O espaço geográfico tem que ser analisado em conjunto com outros conceitos (ou categorias analíticas) para uma melhor compreensão dos processos que resultaram na construção da Paisagem em estudo.

De acordo com Girardi (2008: 35), "é essencial compreender os conceitos de espaço geográfico e território como indissociáveis, pois o território é formado a partir do espaço".

A sociedade também deve ser entendida em sua multidimensionalidade à medida que se procura uni-la em três dimensões essenciais: política, econômica e cultural. Não se explica a formação territorial sem analisar a espacialidade de cada uma dessas dimensões já que existe uma circularidade no território enquanto materialidade. Esta cria representações do espaço que o transformam em espaço produzido, ou seja, formas que são vividas e utilizadas. Assim, nos estudos de análise espacial busca-se a espacialidade de cada uma dessas três dimensões observando as seguintes relações: Espaço-Valor; Espaço-Poder e Espaço-Consciência.

Ao se unir essas três dimensões básicas (econômica, política e cultural) com a História (localizar no Tempo) e a Geografia (localizar no Espaço), com o objetivo de se estudar a formação de algo, tem-se a Formação Territorial. Assim, pode-se dizer que o ato de se apropriar um espaço leva à criação do território.

Não se pode, portanto, explicar a Formação Territorial sem passar pelas três dimensões citadas acima. Assim, o Território é o único (espacialmente) que não dá para ser definido sem a sociedade. Não se pode, portanto, falar em território natural haja vista que é a relação humana que o qualifica. Dessa forma, para haver o território é preciso existir uma relação sociedade/espaço. O território, portanto, é a apropriação que alguém faz desse espaço.

Na abordagem utilizada pelos arquitetos José Ramón Menéndez de Luarca e Arturo Soria y Puig (2000: 16-17), o território deve ser visto como uma construção ou artefato, levando também em consideração o agente, a escala e o tempo:

[...] entre as muitas abordagens possíveis e necessárias ao território, merece também um lugar aquela que o considera como uma construção ou 
artefacto, com uma história e uma linguagem que o constituem no seu conjunto como um objecto cultural.

\section{$[\ldots]$}

Se bem que se deva considerar o território como uma construção, não é menos certo que esta construção tem características únicas que a distinguem das demais. Em particular, o projectista, a escala do projecto e o tempo que demora a realizar-se.

Para Jean Gottmann (1975: 31), como geógrafo, é indispensável definir o território como:

[...] uma porção do espaço geográfico, ou seja, espaço concreto e acessível às atividades humanas. Como tal, o espaço geográfico é contínuo, porém repartido, limitado, ainda que em expansão, diversificado e organizado. $\mathrm{O}$ território é fruto de repartição e de organização. Tal como todas as unidades do espaço geográfico, ele deve ser, em teoria, limitado, embora seu formato possa ser modificado por expansão, encolhimento ou subdivisão.

O geógrafo Claude Raffestin, em sua obra intitulada Por uma Geografia do Poder (1993), faz uma importante abordagem teórico-metodológica acerca das concepções de Território, Territorialidade e relações de poder. Segundo Raffestin (1993: 143), Espaço e Território não são termos equivalentes:

É essencial compreender bem que o espaço é anterior ao território. O território se forma a partir do espaço, é o resultado de uma ação conduzida por um ator sintagmático (ator que realiza um programa) em qualquer nível. Ao se apropriar de um espaço, concreta ou abstratamente (por exemplo, pela representação), o ator "territorializa" o espaço.

Segundo a abordagem de Raffestin, o espaço é a matéria-prima natural que tem um produto que é resultado da ação social, o território, no qual se estabelecem relações de poder (RAFFESTIN, 1993: 144):

O espaço é, portanto, anterior, preexistente a qualquer ação. O espaço é, de certa forma, "dado" como se fosse uma matéria-prima. Preexiste a qualquer ação. "Local" de possibilidades, é a realidade material preexistente a qualquer conhecimento e a qualquer prática dos quais será o objeto a partir do momento em que um ator manifeste a intenção de dele se apoderar. Evidentemente, o território se apoia no espaço, mas não é o espaço. É uma produção, a partir do espaço. Ora, a produção, por causa de todas as relações que envolve, se inscreve num campo de poder.

O território pode ser caracterizado, portanto, como o locus do exercício de poder de uma formação política. A questão central para a compreensão do território, segundo Candiotto (2004: 81), "é quem domina ou influencia e como domina ou influencia esse espaço".

A partir do conceito de território, surgem outros conceitos derivados como Territorialidade e as diversas especificidades de Territórios. Raffestin (1993) entende o 
território como formado por diferentes territorialidades, uso e apropriação do espaço, pelos diferentes agentes. Esse autor define a territorialidade como estratégia utilizada na delimitação e afirmação do controle em uma dada área geográfica, ou seja, de modo a estabelecer, manter e reforçar esse poder (1993: 162):

[...] territorialidade pode ser definida como um conjunto de relações que se originam num sistema tridimensional sociedade-espaço-tempo em vias de atingir a maior autonomia possível, compatível com os recursos do sistema. [...] A territorialidade se manifesta em todas as escalas espaciais e sociais; ela é consubstancial a todas as relações e seria possível dizer que, de certa forma, é a "face vivida" e a "face agida" do poder.

O geógrafo Rogério Haesbaert da Costa (HAESBAERT, 1995) tem discutido a dinâmica "Territorialização/Desterritorialização/Reterritorialização" a partir das perspectivas cultural, política e econômica que envolvem a caracterização do território.

Haesbaert (1995: 168) entende o Território como "um espaço sobre o qual se exerce um domínio político, e como tal, um controle do acesso"; e afirma que existe diferença entre o domínio (político) e a apropriação do espaço (simbólico-cultural). Para esse autor, o território é relacional, ligado ao movimento e às conexões e engloba as dimensões biológica/natural, política (das relações de poder), culturalsimbólica e econômica. Para Haesbaert (2004: 280), "[...] territorializar-se significa também [...] construir e/ou controlar fluxos/redes e criar referenciais simbólicos num espaço em movimento, no e pelo movimento".

A abordagem de Haesbaert sobre a multiterritorialidade abre várias possibilidades de reflexão em relação ao território e às práticas territoriais que o compõem. Descreve o conceito de desterritorialização e discorre sobre território e multiterritorialidade como alternativas para a compreensão da complexidade das relações espaciais. Para o autor, os agentes sociais agem constantemente na construção, destruição e reconstrução de territórios, no que ele denomina de "des-reterritorialização" (HAESBAERT, 2004).

Haesbaert (2004: 286-87) também aborda o conceito de território-rede, o qual concebe o território com características dinâmicas e de mobilidade. Essa mobilidade das dimensões sociais no território implicaria, também, em uma capacidade de adaptação. A abordagem de Haesbaert tenta superar a dicotomia entre território (rigidez, territorialização) e rede (fluidez, des-territorialização). Dessa forma, pensa a rede não apenas enquanto uma forma euclidiana ("conjunto de linhas e pontos") que compõe o espaço, mas como o componente territorial indispensável que enfatiza essa dimensão temporal-móvel ("conexão e 'profundidade") do território:

[...] "um conjunto de linhas e pontos", mas como um componente territorial indispensável que enfatiza a dimensão temporal-móvel do território e que, conjugada com a "superfície" territorial, ressalta seu dinamismo, seu movimento, suas perspectivas de conexão e "profundidade", relativizando a condição estática e dicotômica (em relação ao tempo) que muitos concedem ao território enquanto território-zona num sentido mais tradicional. 
Milton Santos (1999a: 19) propõe a ideia de território usado para tratar das alterações contínuas do território ao longo do tempo. Essa abordagem se adequa à noção de um território em mudança, de um território em processo de adaptação. Para esse autor (SANTOS, 1999b: 8), é o território que constitui o traço de união entre o passado e o futuro: "O território usado é o chão mais a identidade". O território representa o "locus do acontecer da sociedade".

Para Marcos Aurélio Saquet (2004: 81), também geógrafo, o conceito de território, além de relacionado à ideia de poder, também está associado a uma temporalidade:

[...] o território é produzido espaço-temporalmente pelas relações de poder engendradas por um determinado grupo social. Dessa forma, pode ser temporário ou permanente e se efetiva em diferentes escalas.

Logo, essa construção do território corresponde a uma materialidade terrestre, que se adapta a cada época. Portanto, trata-se de um espaço produzido, composto de formas e componentes, criados pela sociedade para responder a uma época, a certas formas de organização produtivas. Conclui-se que o território é construção histórica dotado de uma herança espacial (conjunto de formas criadas) que define o "valor" desse espaço em cada momento.

Essa multitemporalidade está relacionada a uma multiescalaridade, haja vista que "os elementos basilares do território, ou seja, as redes de circulação e comunicação, as relações de poder, as contradições e a identidade, interligam-se, fundem-se umas nas outras numa trama relacional (multitemporal e multiescalar ${ }^{7}$ ) indissociável" (SAQUET, 2007: 158).

Esse autor também trata da diversidade de elementos que compõem o território, no qual existe "uma pluralidade de sujeitos, em relação recíproca, contraditória e de unidade entre si, no e com o lugar e com outros lugares e pessoas; identidades" (SAQUET, 2007: 158). Essa pluralidade de sujeitos pressupõe coexistências e resulta no uso dinâmico do território. Esse uso gera valores de diversas naturezas: culturais, econômicas, sociais, políticas, ideológicas etc.

As comunidades humanas possuem uma estrutura socioeconômica diversificada e o espaço onde habitam também o é possui, e mostram, assim, um território heterogêneo, complexo, condicionado por fatores físicos e culturais. Dessa forma, o território deve ser visto como resultado da ação humana sobre a paisagem, que, por sua vez, consiste em um produto sociocultural criado pela objetivação no espaço físico da ação social, tal como preconiza a Arqueologia da Paisagem (CRIADO-BOADO, 1993).

\section{Sobre a Paisagem...}

Assim como as concepções de Espaço e Território, a definição de Paisagem também está presente nos estudos geográficos. De início, a paisagem aparece, especificamente na pintura e na literatura, como um conceito que contém

\footnotetext{
${ }^{7}$ Ou seja, esses elementos basilares do território são definidos em cada momento em diferentes escalas, do local ao global.
} 
frequentemente significados de caráter estético e artístico. Contudo, sua interpretação se desenvolveu ao longo do tempo nas diversas abordagens, desde Alexander Von Humboldt até as utilizações mais recentes ${ }^{8}$.

O estudo da paisagem foi uma prática habitual nas escolas geográficas tradicionais, em especial na alemã, como percepção de um objeto próprio e como método de investigação, seguindo a linha conceitual e metodológica naturalista, iniciada com Alexander von Humboldt.

Mas foi com Siegfried Passarge que os estudos da paisagem tiveram grande impulso e se tornaram centrais na investigação geográfica. Em 1913, Passarge desenvolveu o termo Geografia da Paisagem (Landschaftgeographie) e, a partir disso, propôs em várias obras o conceito Ciência da Paisagem (Landschaftkunde) (SCHIER, 2003: 83); assim como estabeleceu, pela primeira vez, a diferenciação terminológica entre paisagem natural (Naturlandschaft) e paisagem cultural (Kulturlandschaft).

Sobre a dicotomia "Paisagem Natural" e "Paisagem Cultural", Antonio Gómez Ortiz \& Mari Cruz Melón Arias (2001) dizem:

[...] una porción de la superficie terrestre definida, primordialmente, por sus formas externas, y en la que el hombre viene actuando con más o menos intensidad. Incluso, y con el deseo de perfilar más este concepto se acuñan los términos "paisaje natural" y "paisaje humanizado", según predominen los elementos biofísicos o antrópicos.

O desenvolvimento do estudo da paisagem, no âmbito da Geografia, levou a um aprimoramento na definição do conceito, principalmente, a partir das discussões da dicotomia entre paisagem natural e paisagem cultural, apesar do predomínio da primeira como elemento ideográfico e descritivo.

Com o aparecimento de novas posturas metodológicas e o aprimoramento do conhecimento ecológico e geográfico, surgem propostas para analisar as características do meio natural, como a chamada Ecologia da Paisagem.

O termo Ecologia da Paisagem (Landschaftsökology) foi introduzido pelo biogeógrafo alemão Carl Troll, em 1939. Esse pesquisador, tomando emprestado da Ecologia as leis, os conceitos, as taxonomias corológicas, assim como as relações entre os diferentes componentes do sistema, chegou à conclusão de que:

[...] toda biocenose ${ }^{9}$ está vinculada a condições ambientais bem características que dão origem a um tipo de paisagem [...]; toda biocenose bem característica e marcante é um sistema ecológico onde clima, solo, água, plantas e animais são funcionalmente interligados (TROLL, 1939 apud TROPPMAIR, 2000).

\footnotetext{
8 "As obras 'Cosmos' de Alexander von Humboldt, 'Geografia comparada' de Carl Ritter e 'Antropogeografia' de Friedrich Ratzel são alguns dos exemplos clássicos em que se utilizou o conceito da paisagem como método e transcrição de dados sobre áreas distintas do planeta" (SCHIER, 2003: 82).

${ }^{9}$ Biocenose ou comunidade biótica, é um conceito cunhado pelo zoólogo Karl August Möbius, em 1877, que representa a comunidade que vive em uma dada área geográfica influenciada por fatores físicos. Sobre esse assunto consultar: RICKLEFS, R. E. (2003).
} 
Carl Troll também considerava que "as paisagens culturais e os aspectos sócioeconômicos também deveriam ser considerados" (CHRISTOFOLETTI, 1999: 39). De acordo com Bertrand (2007: 37),

[...] este método representa um progresso decisivo sobre os estudos fragmentados dos geógrafos e dos biogeógrafos, porque ele reagrupa todos os elementos da paisagem, e o lugar reservado ao fenômeno antrópico é bem importante nele.

O reconhecimento da ação humana na transformação da paisagem, influenciando decisivamente na formação de sua estrutura e funcionamento, também está presente na obra de Carl Sauer. Em sua obra Morfologia da Paisagem, publicada em 1925, "tratou a paisagem numa perspectiva morfológica, tanto em aspectos naturais como em aspectos humanos. Para ele, a paisagem cultural representa, consequentemente, uma materialização de pensamentos e ações humanas, mas nunca sai do seu caráter físico-material." (SCHIER, 2003: 83). As inspirações de Sauer são em grande parte provenientes de seu contato com a Geografia Alemã e das obras de Schlüter e Passarge (GOMES, 1996). Foram as proposições contidas em Morfologia da Paisagem que fundamentaram a Geografia Cultural norte-americana, centrada na denominada Escola de Berkeley.

Corrêa \& Rosendahl (1998: 9) indicam que, para Sauer, a paisagem geográfica, vista como um conjunto de formas naturais e culturais associadas em uma dada área, é analisada morfologicamente, percebendo-se a integração das formas entre si e o caráter orgânico ou quase orgânico delas. E o tempo é uma variável fundamental. A paisagem cultural ou geográfica resulta da ação, ao longo do tempo, da cultura sobre a paisagem natural.

Para Criado-Boado \& Barreiro (2016: 15),

A insistencia na noción de paisaxe cultural (e a persistencia no seu uso a nível de discurso), mais que na de paisaxe, ten moito que ver coa intención de superar dous prexuízos habituais respecto á paisaxe: que é algo natural (isto é, confunde a paisaxe co ambiente) ou que é algo estético ou artístico (isto é, confunde a paisaxe coa representación da paisaxe).

Essa paisagem, denominada de cultural ou humanizada, pode então ser entendida como resultante da interação entre os seres humanos e a natureza, ou seja, como o exercício de uma função própria dos seres humanos que evolui de acordo com as forças de cada época no estabelecimento de relações entre ambos (ANDRESEN, 1992). Assim, a paisagem como fenômeno cultural é dinâmica e transforma-se com o passar do tempo e, portanto, pode ser interpretada como um palimpsesto devido à sua construção ocorrer constantemente.

Milton Santos, em seu livro A Natureza do Espaço (2002: 107), define a paisagem como sendo transtemporal, pois congrega objetos passados e presentes em uma construção transversal. Já o espaço é sempre o presente, uma construção horizontal, uma situação única. O seu caráter de palimpsesto revela um passado já morto que permite rever as etapas do passado numa perspectiva de conjunto. "A 
paisagem é história congelada, mas participa da história viva. São suas formas que realizam, no espaço, as funções sociais".

Essa construção e reconstrução da paisagem de acordo com a necessidade humana de interagir com o meio pode ser evidenciada por numerosos exemplos do passado, os quais constatam que o processo de humanização da paisagem não é produto apenas do mundo pós-revolução industrial, mas faz parte do próprio processo histórico. Dessa forma, podemos concluir que a paisagem é uma herança desse processo histórico. O espaço vai se configurar devido aos grupos humanos estabelecidos ali que vão cunhar sua paisagem cultural.

Em uma perspectiva histórica, é evidente que o legado ambiental que temos hoje é produto das relações de populações passadas com o meio. Entretanto, partir do pressuposto de que a paisagem é o resultado da intervenção humana sobre o meio pode servir como ensaio, mas não proporciona uma definição suficiente desse conceito (SASTRE PRATS, 1999: 3).

Os espaços historicamente ocupados apresentam símbolos culturais que se refletem não apenas nos objetos ou estruturas materiais, mas também na própria organização da paisagem. Assim, podemos colocar como ponto de partida que toda paisagem é, necessariamente, uma realidade cultural, e é isto que lhe dá sentido como objeto de investigação histórica (OREJAS, 1995-96: 63). A paisagem é a fusão da natureza com a cultura; ou melhor, é o resultado da coevolução das duas em conjunto com a maneira como os seres humanospercebem essa interdependência (CRIADO-BOADO; BARREIRO, 2016: 15).

Nas novas definições conceituais, a paisagem passa a ser matéria de interesse e investigação de diversas áreas do conhecimento, além da própria Geografia Cultural. Como visto, a paisagem é um conceito polissêmico, e é possível estudá-la a partir de vários pontos de vista, entre eles o da Arqueologia. Nessa perspectiva, "paisagem" deve ser entendida como um conceito transdisciplinar e multidisciplinar (CRIADOBOADO; BARREIRO, 2016: 13). Segundo Philippe Leveau (2006: 10):

Le paysage est donc ce que l'on peut appeler un concept "puits» plutôt que "source». Placé à l'aboutissement de dynamiques spatiales et chronologiques et de facteurs d'origine naturelle ou anthropique, il justifie une extrême diversité d'approches. Le paysage est tout à la fois le paysage très minéral des géographes physiciens, celui que masque le couvert végétal étudié par les écologues, et, bien entendu, celui auquel les hommes donnent une forme en y insérant le réseau des chemins et des routes qui relient entre elles leurs habitations et assurent la desserte des champs. Un paysage s'analyse en de multiples composantes qui justifient la place des disciplines qui concourent à cette opération. II peut être vu de plusieurs points et apparaître di Äérent selon le choix e Äectué. Cette malléabilité du concept de paysage entre pour une large part dans son succès chez les archéologues.

A partir dessa maleabilidade do conceito de paisagem, pode-se concluir que ela (a paisagem) é o produto de uma interligação dinâmica e flexível entre seus componentes formadores: os elementos físico-naturais, sociais e culturais, implicando em um sistema integrador. 
Dardel (2011: 31-32), a partir do ponto de vista da fenomenologia, apresenta a paisagem como o elo de ligação entre o ser humano e a terra, "base de seu ser social".

[A paisagem] coloca em questão a totalidade do ser humano, suas ligações existenciais com a terra, ou, se preferirmos, sua geograficidade original: a Terra como lugar, base e meio de sua realização.

Uma das linhas argumentativas empregadas na presente pesquisa leva em consideração que a paisagem é a fusão do natural e do cultural. Dessa forma, e de acordo com a reflexão de Criado-Boado \& Barreiro (2016: 15), a paisagem:

[...] A paisaxe é algo mais ca natureza ou cultura, é a fusión de ambas e é, de feito, o resultado da coevolución de ambas conxuntada coa forma em como os seres humanos percibimos esa interdependencia e o seu resultado.

\subsection{Enquadramento Teórico - Distintos enfoques, uma mesma Arqueologia}

Entre as décadas de 70 e 90 do século XX, a Arqueologia passou por uma fase de esclarecimento metodológico de seus objetivos. Além da utilização justaposta de conceitos geográficos de análise espacial (espaço, território, paisagem, região e lugar) nos estudos arqueológicos, também surgiram algumas terminologias arqueológicas para denominar distintos enfoques direcionados a esse tipo de estudo: Arqueologia Espacial, Arqueologia do Território e Arqueologia da Paisagem.

Para Wendy Ashmore (1999),

[...] the range of archaeological pursuits that focus on study of the spatial aspects of the archaeological record. These pursuits certainly do not constitute a separable "field," but, rather, a set of perspectives on studying ancient societies and cultures, emphasizing position, arrangement, and orientation, and examined at a range of scales: from individual buildings or monuments, caches, and burials, to settlements, landscapes, and regions. Architecture and the built environment, generally, are only a part of the whole, and discussion of them here highlights their two-dimensional aspects or plan view.

Esse parcelamento terminológico leva criar a aparência de "diversas Arqueologias", que Ruiz Zapatero \& Burillo Mozota (1988: 45) chamam de "falsas Arqueologias":

[...] el peligro de crear la apariencia de encontrarnos ante diversas Arqueologías - "falsas Arqueologías" -, cada una con su entidad propia, aislada, que cumple en su desarrollo un fin completo, nada sería epistemológicamente más peligroso. Y así como esas "falsas Arqueologías" no son más que aproximaciones específicas a aspectos concretos del registro arqueológico, el estudio del Territorio también debe enfocarse, 
simplemente, como uno de los temas a investigar dentro de una concepción globalizadora de la Arqueología.

$\mathrm{Na}$ perspectiva Arqueológica, a análise e compreensão dos padrões de distribuição dos sítios arqueológicos, a organização interna dos povoados antigos, a influência da paisagem na vida do homem, as formas de apropriação e transformação da natureza pelas sociedades pretéritas foram desde sempre áreas de grande interesse. Exemplos disso foram as publicações das obras Locational Analysis in Human Geography (HAGGETT, 1965) e Models of Geography (CHORLEY \& HAGGETT, 1967), provenientes da Escola de Geografia Locacional de Cambridge, que influenciaram a escola inglesa da Nova Arqueologia, liderada por David L. Clarke.

Os primeiros estudos sistemáticos relacionados à análise espacial dos sítios arqueológicos foram inicialmente introduzidos por Gordon Willey (1953) nos estudos do Vale do Rio Viru, no Peru10, a partir da perspectiva de uma Arqueologia Regional. Willey, influenciado pela Ecologia Cultural de Julian Steward, propôs o conceito de "Padrões de Assentamento" como sendo "a maneira como o homem se dispõe sobre a paisagem onde vive" (WILLEY,1953: 1 apud PARSONS, 1972: 129):

The term 'settlement patterns' is defined here as the way in which man disposed himself over the landscape on which he lived. It refers to dwellings, to their arrangement, and to the nature and disposition on the others buildings pertaining to community life. These settlements reflect the natural environment, the level of technology on which the builders operated, and various institutions of social interaction and control which the culture maintained. Because settlement patterns are, to a large extent, directly shaped by widely held cultural needs, they offer a strategic starting point for the functional interpretation of archaeological cultures.

Esse termo proposto por Willey procura associar as variáveis ambientais, culturais e tecnológicas. Posteriormente, esse conceito foi trabalhado por Winters (1968) que o denominou "Sistemas de Assentamentos", dando ênfase às relações funcionais entre os sítios arqueológicos. Também conhecido como "Arqueologia dos Assentamentos", esse conceito foi retomado e redefinido por Eric Higgs (1970) ao tratar de seu Site Catchment Analysis, no qual a influência da Ecologia Cultural é evidente.

Os estudos realizados por Higgs \& Vita-Finzi (1970) estão relacionados aos modelos de análise de captação de recursos, no sentido de possibilitar a determinação das variáveis ambientais em um dado território ideal de exploração no qual as populações tenderiam a minimizar os esforços na obtenção desses recursos. VitaFinzi \& Higgs (1970: 5) assim o definem: "the study of relationship between technology and those natural resources lying within economic range of individual sites".

Nesses estudos, "território" corresponderia à área geralmente explorada a partir de um assentamento (HIGGS \& VITA-FINZI, 1972: 30). Entretanto, posteriormente, o qualificaram como "Território de Exploração" (BAYLEY \& DAVIDSON, 1983).

\footnotetext{
${ }^{10}$ A obra de Willey, intitulada Prehistoric Settlement Pattern in the Virú Valley, Peru (1953), foi resultado de um estudo arqueológico e antropológico realizados por antropólogos americanos e peruanos em um pequeno vale costeiro do Peru, em 1946 (TRIGGER, 2004: 272).
} 
Butzer (1989: 203) também define o registro arqueológico a partir de um enfoque ambiental quando diz que ele é

[...] parte de un ecosistema humano en el que las comunidades del pasado se interrelacionaban espacial, económica y socialmente con la trama medioambiental donde estaban integrados adaptativamente.

Dessa forma, o foco de estudo passa a ser a análise espacial dos sítios arqueológicos, ou seja, sua espacialidade na paisagem relacionada às formas de interação dos assentamentos humanos com o entorno e os padrões de articulação entre eles. Para Araújo (2001: 89), o padrão de distribuição de sítios é "a descrição das relações espaciais que os vestígios arqueológicos apresentam entre si e com a paisagem".

Esse tipo de abordagem, também conhecida como Arqueologia Espacial, foi divulgada por arqueólogos ingleses - em especial por Hodder \& Orton, 1976; Clarke, 1977 - nas décadas de 70/80 do século XX. Desenvolveu-se, principalmente em escala regional, baseada nas teorias espaciais da Nova Geografia, da Ecologia Cultural e na Geografia Econômica Alemã ${ }^{11}$.

A denominada Nova Arqueologia atuou principalmente em dois pontos: a prospecção intensiva como uma técnica arqueológica fundamental para o estudo do território, e na incorporação aos estudos arqueológicos de ferramentas de interpretação espacial provenientes da Geografia (ARIÑO GIL, GURT \& PALET, 2004: 14).

De um modo geral, a análise espacial arqueológica seria o conjunto de técnicas cujos resultados são dependentes da localização dos objetos analisados (GOODCHILD, 1996: 241). De uma maneira mais detalhada, David Clarke, autor de Spatial Archaeology (1977), define a Arqueologia Espacial logo no início de sua obra:

Spatial archeology might be defined as - the retrieval of information from archaeological spatial relationships and the study of the spatial consequences of former hominid activity patterns within and between features and structures and their articulation within sites, site systems and their environments: the study of the flow and integration of activities within and between structures, sites and resources spaces from the micro to the semi-micro and macro scales of aggregation. (CLARKE, 1977: 9).

Clarke, ao trabalhar a noção de territorialidade, propõe a possibilidade de obtenção e acumulação de informações através de três níveis (ou escalas) de análise: micro, semi-micro e macro. O nível micro diz respeito ao interior do sítio, ou seja, dentro das estruturas (abrigos, casas, cemitérios, templos etc.); o nível semi-micro se refere ao conjunto das estruturas do sítio, ou seja, o sítio em si e suas relações com o entorno; e o nível macro diz respeito às relações do sítio em escala regional, com as paisagens, com sítios numa região, locais de captação de recursos, locais de atividades etc.

11 As principais teorias espaciais da geografia econômica, denominadas de Teoria Clássica da Localização, podem ser exemplificadas a partir do "Modelo de Localização das atividades agrícolas" de Johann Heinrich Von Thünen (1826), do "Modelo da Localização industrial" de Alfred Weber (1909), da "Teoria dos Lugares de Centrais" de Walter Christaller (1933) e da "Teoria do Equilíbrio Espacial" de August Lösch (1940). 
Essas três escalas, ou níveis de análises espaciais, são arbitrárias, haja vista que na realidade as relações espaciais formam um fluido contínuo e constante. $E$, naturalmente, elas operam dentro de escalas e magnitudes cartográficas muito diferentes (GARCÍA SANJUÁN, 2005: 201-203). A Tabela 1.2.a, abaixo, apresenta uma síntese das escalas espaço-temporais de representação e análise espacial.

Tabela 1.2.a

Escalas Espaço-Temporais de Representação e Análise Espacial

\begin{tabular}{|c|c|c|c|c|c|}
\hline $\begin{array}{c}\text { Escala } \\
\text { Arqueológica }\end{array}$ & $\begin{array}{l}\text { Extensão } \\
\text { Espacial }\end{array}$ & $\begin{array}{c}\text { Escala } \\
\text { Cartográfica }\end{array}$ & Exemplo & $\begin{array}{c}\text { Ordem } \\
\text { Biológica }\end{array}$ & $\begin{array}{c}\text { Ordem } \\
\text { Humana }\end{array}$ \\
\hline $\begin{array}{l}\text { Super-macro } \\
\text { - Teoria Super- } \\
\text { Macro }\end{array}$ & $\begin{array}{l}\geq 10^{7} \mathrm{~km}^{2} \\
10^{6} \mathrm{~km}^{2}\end{array}$ & $\begin{array}{l}<1: 10.000 .000 \\
\\
1: 5.000 .000 \\
1: 1.000 .000 \\
\end{array}$ & $\begin{array}{l}\text { Plataformas } \\
\text { continentais, Velho } \\
\text { Mundo, Oceanos } \\
\text { Domínio herciniano, } \\
\text { Península Ibérica }\end{array}$ & $\begin{array}{l}\text { Zona } \\
1.000 .000- \\
100.000 \text { anos } \\
\\
\text { Domínio } \\
1.000 .000- \\
1000.000 \text { anos }\end{array}$ & $\begin{array}{l}\text { Zona } \\
\text { Domínio } \\
\text { País }\end{array}$ \\
\hline $\begin{array}{l}\text { Macro } \\
\text { - Teoria do Lugar } \\
\text { Central } \\
\text { - Modelo X-TENT } \\
\text { - Análise de } \\
\text { Polígonos de } \\
\text { Thiessen } \\
\text { - Coeficiente do } \\
\text { Vizinho Mais } \\
\text { Próximo }\end{array}$ & $\begin{array}{l}10^{5} \mathrm{~km}^{2} \\
10^{4} \mathrm{~km}^{2} \\
10^{3} \mathrm{~km}^{2}\end{array}$ & $\begin{array}{l}1: 500.000 \\
1: 200.000 \\
1: 200.000 \\
1: 100.000\end{array}$ & $\begin{array}{l}\text { Meseta central } \\
\text { espanhola, } \\
\text { Andaluzia } \\
\text { Vale do } \\
\text { Guadalquivir, Serra } \\
\text { Morena ocidental } \\
\text { Jerez de los } \\
\text { Caballeros, } \\
\text { Carmona }\end{array}$ & $\begin{array}{l}\text { Geosistema } \\
10.000-1.000 \\
\text { anos }\end{array}$ & $\begin{array}{l}\text { Região } \\
\text { Província } \\
\text { Parque natural } \\
\text { Comarca } \\
\text { Comarca } \\
\text { Município }\end{array}$ \\
\hline $\begin{array}{l}\text { Macro/Semi-micro } \\
\text { - Análise de } \\
\text { Captação de } \\
\text { Recursos (Site } \\
\text { Catchment } \\
\text { Analysis) } \\
\end{array}$ & $10^{2} \mathrm{~km}^{2}$ & $\begin{array}{l}1: 20.000 \\
1: 10.000\end{array}$ & $\begin{array}{l}\text { Seção de um vale, } \\
\text { cidade, lago }\end{array}$ & $\begin{array}{l}\text { Geofacies } \\
1.000-100 \\
\text { anos }\end{array}$ & $\begin{array}{l}\text { Município } \\
\text { Setor }\end{array}$ \\
\hline Semi-micro & $10 \mathrm{~km}^{2}$ & $\begin{array}{l}1: 5.000 \\
1: 2.000 \\
1: 2.000 \\
1: 1.000 \\
\end{array}$ & $\begin{array}{l}\text { Um declive, } \\
\text { depósito aluvial, um } \\
\text { assentamento pré- } \\
\text { histórico e seu } \\
\text { ambiente } \\
\text { Um declive, um } \\
\text { assentamento pré- } \\
\text { histórico }\end{array}$ & $\begin{array}{l}\text { Geotopo } \\
100 \text { anos } \\
\text { Biotopo } \\
1-10 \text { anos }\end{array}$ & $\begin{array}{l}\text { Cidade } \\
\text { Habitat } \\
\text { Bairro } \\
\text { Habitat }\end{array}$ \\
\hline Micro & $\leq 1$ ha & $\begin{array}{l}1: 1.000 \\
1: 100\end{array}$ & $\begin{array}{l}\text { Uma tumba, uma } \\
\text { casa, uma } \\
\text { propriedade, um } \\
\text { lote de terreno }\end{array}$ & $\begin{array}{l}\text { Biotopo } \\
1-10 \text { anos }\end{array}$ & $\begin{array}{l}\text { Propriedade } \\
\text { Casa } \\
\text { Quinta }\end{array}$ \\
\hline
\end{tabular}

Fonte: Tabela adaptada de Joly (1979: 46-47). 
Os trabalhos de D. Clarke deram uma nova dimensão à análise espacial em Arqueologia. As divisões do espaço arqueológico (micro, semi-micro e macro) se mantêm ainda vigentes e foram ampliadas com uma nova escala: super-macro. Essa escala surgiu da aplicação das teorias de Immanuel Wallerstein sobre o SistemaMundo (WALLERSTEIN, 1975, 1980; WOOLF, 1998: 44-58).

Clarke (1977) também definiu sete elementos fundamentais da Arqueologia Espacial: matéria-prima; artefatos; estruturas construídas (de qualquer tipo); partes de estruturas construídas; vias de comunicação; locais de matérias-primas; humanos.

Para Clarke, as integrações e os fluxos são vistos, principalmente, do ponto de vista econômico (com ênfase no nível macro) e podem ser reconhecidos através da análise locacional e de teorias espaciais provenientes da economia, arquitetura, física, antropologia e processos estocásticos ${ }^{12}$.

O ponto atrativo da abordagem da Arqueologia Espacial é seu potencial para o entendimento de padrões de comportamento econômico humano como sendo espacialmente organizados. Outra vantagem dessa abordagem é sua natureza formal e sua linguagem que permite uma série de análises quantitativas e computacionais de modelos preditivos de ocupação do espaço.

Uma base importante para essas análises é o conceito implícito sobre o comportamento racional humano nos processos de tomada de decisão. O comportamento humano é considerado a tender continuamente para o aumento da eficiência, ou seja, uma racionalidade voltada para o mínimo dispêndio de energia, tendo como princípio a otimização dos recursos. Assim, todas as estruturas espaciais são os produtos de decisões humanas não-aleatórias e são espelhadas em regularidades repetidas. São essas regularidades o principal objeto de estudo da Arqueologia Espacial.

Dessa forma, os modelos de análise locacional, além dos instrumentos estatísticos e matemáticos, são utilizados para interpretar o caráter não aleatório da distribuição espacial dos vestígios materiais. Entretanto, Leonardo García Sanjuán (2005: 209) observa algumas críticas metodológicas relacionadas aos modelos de análise de captação de recursos derivados dos seguintes aspectos:

i) de la utilización mecánica de datos contemporáneos (actuales) sobre potencialidad agraria y uso del suelo sin el adecuado soporte de evidencias de carácter paleoambiental (Butzer, 1989: 209);

ii) de la reducción del modelo a la mera descripción de las características del medio físico en torno a un asentamiento o serie de ellos (Roper, 1979: 132); $y$

iii) de la utilización sistemática, y no argumentada teóricamente, de círculos concéntricos de un rayo fijo para delimitar el área de captación.

Outro ponto importante a ser considerado é que a utilização desses modelos de análise locacional, muito difundidos nos estudos pré-históricos, é de aplicação inviável sob as mesmas premissas, para o estudo de períodos históricos como, por exemplo, o

\footnotetext{
12 Processos com origem em variáveis aleatórias; é relacionado a teoria das probabilidades.
} 
do mundo romano. Segundo Cerrillo Martín de Cáceres \& Fernández Corrales (1980: 159), os conceitos teóricos do Site Catchment Analysis não são válidos para a época romana devido à existência de um elemento "autoperpetuador":

[...] el concepto jurídico de propiedad, cuya aplicación sobre la tierra se traduce en 'fundus' y en una clara y concisa delimitación de los campos de creación de bienes y recursos mediante una técnica planificada.

Para aplicar esse modelo de análise locacional, que procura reconstruir os padrões de exploração dos recursos em um dado território, em estudos do mundo antigo é necessário, previamente, fazer uma série de retificações nas propostas feitas originalmente por Higgs \& Vita-Finzi (1970: 1-37) e Jarman, Vita-Finzi \& Higgs (1972: 61-66). Isso se deve pelas características próprias do mundo antigo, que o individualizam em relação aos estudos pré-históricos. Entre elas se destacam a estabilidade demográfica, política, social e econômica (CERRILLO MARTíN DE CÁCERES \& FERNÁNDEZ CORRALES, 1980: 159), além de outra ordem de mentalidades. Fatores esses que permitem e geram novas formas de ocupação e articulação no território que, apesar de "herdeira" de períodos anteriores, possui múltiplos traços originais.

Os demais modelos teóricos de análise locacional, para escala macro, apresentam uma diversidade de aplicações, como, por exemplo, a estimativa de áreas de influência e controle dos assentamentos no território, assim como limites e fronteiras entre comunidades. Alguns desses principais modelos para análise da territorialidade são: Teoria do Lugar Central ${ }^{13}$, Análise de Polígonos de Thiessen/Diagramas de Voronoi ${ }^{14}$, Modelo X-TENT ${ }^{15}$, Coeficiente de Gravidade ${ }^{16}$, Coeficiente do Ponto de Equilíbrio Espaço-População ${ }^{17}$, Coeficiente do Vizinho Mais Próximo $^{18}$, Modelo de Regressão Linear ${ }^{19}$ e Análise da Preponderância Topográfica ${ }^{20}$.

\footnotetext{
${ }^{13}$ Essa teoria, foi desenvolvida por Lösch (1940) e Christaller (1933), ficando, em conjunto, conhecida como "Teoria do Lugar Central" (TLC). A TLC é um dos modelos de análise de territorialidade teórica. Basicamente, trata-se de um modelo de geografia humana de análise da distribuição de populações e suas áreas de influência e atração. Dessa forma, visa explicar a hierarquização do território através de alguns fatores como tamanho, densidade e proximidade dos núcleos populacionais (GARCÍA SANJUÁN, 2005: 209-212).

${ }_{14}$ A denominação "Polígonos de Thiessen" foi uma homenagem ao meteorologista estadunidense Alfred H. Thiessen. Trata-se de uma construção geométrica que permite construir uma partição do plano euclidiano para estabelecer áreas teóricas de influência e/ou serviços dentro de uma área de assentamentos. Também foi estudado pelo matemático russo Georgy Voronoi, daí o nome alternativo de "Diagramas de Voronoi"; e, também, pelo matemático alemão Gustav Lejeune Dirichlet, de onde toma o nome de "Distribuição de Dirichlet" (GARCÍA SANJUÁN, 2005: 212-215).

15 O "Modelo X-TENT" está baseado no princípio rank-size: um nível mais político, maior tamanho do assentamento e maior território controlado (GARCÍA SANJUÁN, 2005: 215-216).

16 O "Coeficiente de Gravidade" se refere à noção de que a interação entre dois assentamentos é diretamente proporcional ao número de pessoas que vivem neles e inversamente proporcional à distância entre ambos (GARCÍA SANJUÁN, 2005: 216-217).

17 O "Coeficiente do Ponto de Equilíbrio Espaço-População" é uma alternativa ao estudo da territorialidade teórica com base no tamanho dos assentamentos. O ponto de equilíbrio entre dois assentamentos define o lugar onde se situa o limite entre ambos e sua localização estaria em função do tamanho de cada assentamento (GARCÍA SANJUÁN, 2005: 216).

18 O "Coeficiente do Vizinho Mais Próximo" deriva da Ecologia (CLARK \& EVANS, 1954) e oferece uma medida do grau de agrupamento com dispersão de uma distribuição de pontos (assentamentos). Aplica-se, portanto, aos estudos de densidade de assentamentos (GARCÍA SANJUÁN, 2005: 217-218).

19 O "Modelo de Regressão Linear" visa estabelecer a extensão da distribuição dos artefatos a partir de determinados centros produtores (GARCÍA SANJUÁN, 2005: 219).

20 A "Análise da Preponderância Topográfica" sugere a localização geográfica como um fator importante na escolha do local, tanto dos assentamentos (controle e domínio visual do território), quanto dos monumentos e sítios de importância simbólica (lugares especialmente visíveis) (GARCíA SANJUÁN, 2005: 219).
} 
Entretanto, Susan Kent, em seu trabalho Method and Theory for Activity Area Research (1987), chama a atenção sobre a necessidade de ter cautela com o uso indiscriminado de modelos estatísticos, que tentam trazer respostas complexas e sofisticadas, mas, na maioria das vezes, irreais para os estudos espaciais.

Enrique Luís Domínguez Berenjeno (2001: 109-122), em seu artigo intitulado “Arqueología y Territorio: de la 'interpretación arqueológica' al 'dato histórico", faz críticas às aplicações de modelos espaciais realizadas pela denominada Escola de Jaén, como é conhecido um grupo de investigação formado no Colégio Universitário de Jaén ${ }^{21}$ (atual Universidad de Jaén) ligado ao enfoque da "Arqueologia Espacial", que surgiu na Espanha na década de 1980. Apesar da diversidade e heterogeneidade de tendências presentes na Escola de Jaén, as críticas de Domínguez Berenjeno (2001: 115) destacam, principalmente, a excessiva dependência de técnicas procedentes da Geografia locacional, de forma acrítica, e a homogeneidade teórica em torno a uma proposta "materialista". Nas palavras de Domínguez Berenjeno (2001: 115):

[...] aguda incoherencia entre el planteamiento "teórico" y su aplicación práctica. Lo cual se ve agravado porque, en última instancia, la aplicación de dichas técnicas no conduce a ningún resultado, pues las conclusiones se extraen finalmente del análisis de los condicionantes geográficos y de la aplicación de un modelo predeterminado de formación económico-social.

Essas críticas se devem, na maior parte das vezes, à aplicação simplista e/ou abusiva desses modelos. Domínguez Berenjeno (2001: 111) destaca a importância da explicitação da metodologia de trabalho utilizada. Na mesma direção, Susan Kent (1987: 51) enfatiza a necessidade de relacionar as estratégias de amostragem e os objetivos da pesquisa na interpretação e compreensão do registro arqueológico "to stimulate archaeologists to develop methods and theories/models appropriate to their activity area descriptions and interpretations".

Como esses modelos e teorias foram concebidos como ferramentas para o reconhecimento do território (VITA-FINZI, 1978: 29), essas afirmações acima devem ser observadas quando de sua aplicação já que constituem boas ferramentas de análise espacial, haja vista que a análise numérica/estatística de correspondência entre a paisagem cultural e a estrutura socioeconômica oferece interessantes possibilidades para se entender os componentes da atividade humana mais relevantes na explicação do espaço territorial e da função da paisagem.

Os estudos orientados para os padrões de intervisibilidade e campos visuais também têm desempenhado um papel particularmente importante nas análises espaciais em Arqueologia (GARCÍA SANJUÁN, 2005: 222). Nesse sentido, a visibilidade é entendida no sentido empírico da acessibilidade sensorial de características antrópicas e naturais da paisagem, sob determinadas condições de distância, topografia e ambiente atmosférico. E não no sentido do registro de visibilidade da superfície para fins de área de prospecção (AGUILÓ et al., 1993: 544-546). Entre

21 O Colégio Universitário de Jaén será tratado a seguir quando tratarmos da nomenclatura Arqueologia Territorial. 
esses modelos de análise, destacam-se dois: "Cálculo de Visibilidade"22 e "Cálculo de Rotas Ótimas ou Ideais"23.

Para a aplicação desses modelos e teorias de análise espacial, as chamadas Geotecnologias, em especial os Sistemas de Informação Geográfica (SIG), constituem um ferramental geotecnológico fundamental ${ }^{24}$. Para João Fonte (2015: 46),

[...] a actual relevância das tecnologias geoespaciais em arqueologia, especialmente dos SIG's, pode-se explicar pela natureza espácio-temporal inerente ao registro arqueológico, bem como pela tradicional importância do mapeamento a diferentes escalas em arqueologia, desde uma escala micro, intra-sítio, até uma escala macro, de âmbito regional.

Dessa forma, recentemente, diversos autores (FÁBREGA-ÁLVAREZ, 2006; WHITLEY \& BURNS, 2008; LLOBERA et al., 2011) têm dado atenção às amplas possibilidades que as geotecnologias podem oferecer para a interpretação arqueológica na aplicação de análises de mobilidade e acessibilidade. Essas aplicações vão além da construção de rotas e estendem-se a análises mais amplas relacionadas à utilização e percepção da paisagem.

O uso desse ferramental geotecnológico será abordado, de maneira específica, no tópico 1.3 desta pesquisa referente ao enquadramento metodológico.

A "Arqueologia Espacial" que se desenvolveu nos anos 1980, na Espanha, resultou em novas propostas metodológicas e postulados teóricos relacionados aos conceitos de "Arqueologia do Território" e/ou "Arqueologia da Paisagem". Para Ruiz Molinos \& Risquez (1998: 22):

La complejidad de los conceptos empleados hace necesario establecer una profunda reflexión que defina la validez de aquellos que como territorio o paisaje han desplazado el aséptico término espacial, o en todo caso valorar si su definición responde a conceptos realmente opuestos en términos teóricos o solo a percepciones distintas de un mismo discurso que en definitiva trata de construir una unidad de análisis superior al objeto arqueológico tradicional. En suma una teoría de la arqueología capaz de adecuar su tratamiento de investigación a los nuevos tempos.

A nomenclatura Arqueologia do Território, ou Arqueologia Territorial, é utilizada particularmente em âmbito espanhol ${ }^{25}$ e surgiu das aplicações de modelos geográficos

22 O "Cálculo de Visibilidade" pode ser aplicado na avaliação do domínio visual, como um instrumento de controle e gestão do território; e, também, em dados importantes na análise de sociedades com necessidades defensivas (GARCÍA SANJUÁN, 2005: 222-229). Para estudos mais aprofundados, ver: WHEATLEY, D (1995: 171-85); WHEATLEY \& GILLINGS (2000: 1-27) e LLOBERA (2003: 25-48).

23 O "Cálculo de Rotas Ótimas ou Ideais" está relacionado às aplicações em áreas de aproximação hipoteticamente ocupadas; na definição de eixos viários naturais; e no estabelecimento de regularidades entre diferentes depósitos em função da proximidade/afastamento dos caminhos. Sobre essa aplicação ver: LLOBERA (2000: 65-84); HARRIS (2000: 116-123); VAN LEUSEN (2002: 1-20); LÓPEZ ROMERO (2005); LLOBERA, FÁBREGA-ÁLVAREZ \& PARCERO-OUBIÑA (2011: 843-851) e OLAYA (2016).

24 Assunto que será visto de forma mais aprofundada no próximo tópico: "1.3. Enquadramento Metodológico - As Geotecnologias na interpretação da paisagem arqueológica".

${ }^{25}$ Estudos relacionado ao tema Arqueologia do Território podem ser encontrados nos trabalhos de: RUIZ ZAPATERO \& BURILLO MOZOTA (1988: 45-64); NOCETE (1994); RUIZ, MOLINOS \& RISQUEZ (1998: 2132); CASTRO (1999); GUTIÉRREZ SOLER \& BELLÓN RUIZ (2001: 37-58); GARCÍA SANJUÁN (2005); ZEDEÑO (2008: 210-217); e MARTÍNEZ PADILLA (2010: 11-24). 
nas pesquisas arqueológicas desenvolvidas pelo antigo Colegio Universitario de Jaén. A Universidad de Jaén e o Grupo de Investigación del Patrimonio Arqueológico de Jaén (GIPAJ) têm uma longa trajetória arqueológica dedicada ao debate sobre territorialidade, como pode ser observado nos volumes da série "Arqueología Espacial"26.

Para Ruiz Zapatero \& Burillo Mozota (1988: 46), a Arqueologia Territorial corresponde à Arqueologia Regional, ou Análise Regional em Arqueologia (JOHNSON, 1977). Entretanto, para o arqueólogo Francisco Nocete Calvo (NOCETE, 1990: 81), "não existe uma Arqueologia do Território, mas uma Arqueologia para explicar a Formação Social". Ou seja, a análise do território não é um objetivo em si mesmo, mas um caminho ao estudo das realidades sociais que determinam a formação desse território.

O que se percebe nesses debates é que há uma convergência de tendências diversas que tem gerado uma dinâmica de trabalho muito produtiva (apesar de apresentar certa confusão conceitual em alguns estudos). E isso pode ser observado nos trabalhos de arqueólogos que "faziam", desde os anos 80, uma Arqueologia Espacial e que, atualmente, praticam uma Arqueologia da Paisagem. O caso mais significativo desse esforço teórico talvez seja o da investigadora do Consejo Superior de Investigaciones Científicas - CSIC, Almudena Orejas Saco del Valle (OREJAS, 1995, 1995-1996, 1998, 2002, 2008), que fez da temática paisagem o eixo central de seus trabalhos.

Portanto, já nos finais dos anos 80 , principalmente no âmbito da Arqueologia da Península Ibérica, houve uma alteração em relação à concepção do registro arqueológico. Este deixa de estar centrado apenas no sítio arqueológico e passa a ser visto em uma escala mais ampla, na qual o espaço, o território e a paisagem serão os objetos a partir dos quais se transforma o próprio registro arqueológico (FONTE, 2009/10: 97).

Assim, nos últimos anos (década de 1990 em diante), desenvolveu-se, nos estudos arqueológicos, o conceito do registro arqueológico como "paisagem" (OREJAS, 1995). Essa abordagem, desenvolvida no Grupo de Investigación en Arqueología del Paisaje da Universidade de Santiago de Compostela ${ }^{27}$, além de levar a uma renovação das abordagens teórico-metodológicas, fornece, também, um ponto de partida importante aos estudos arqueológicos e históricos direcionados à análise das relações de exploração e dependência, em torno das quais se articulam as formações sociais.

A Arqueologia da Paisagem surge, assim, como uma abordagem com vocação multidisciplinar e integradora. Segundo Criado-Boado (2013: 02):

La historia trata del tiempo. La geografía del espacio. La arqueología de las formas. La Arqueología del Paisaje trata de las formas del espacio en el tiempo. Es un programa de investigación de vocación multidisciplinar e integradora, que se ocupa de temas que están a caballo de diferentes disciplinas. Posee vocación de compromiso con el presente. Produce un

\footnotetext{
26 O periódico Arqueología Espacial surgiu a partir das discussões ocorridas durante o Colóquio sobre distribuición y relaciones entre los asentamientos, que foi celebrado em Teruel, em 1984.

${ }^{27}$ Atual grupo de pesquisa "Arqueología del Paisaje y Paisajes Culturales" do Incipit/CSIC.
} 
conocimiento con proyección práctica o utilitaria, que puede contribuir a una mejor comprensión y ordenación del territorio.

Para González Villaescusa (2006: 75), "[es] más acertado considerar a ambas corrientes como disciplinas que confluyen en un momento determinado, como consecuencia de los objetos comunes que tienen como referente". A Arqueologia da Paisagem pode assim ser considerada uma abordagem mais aprofundada que a Arqueologia Espacial, ou, também, um resultado das tendências teóricas da chamada Arqueologia Pós-Processual. Para João Fonte (2015: 43):

A Arqueologia da Paisagem não pretende apenas considerar o registro arqueológico a uma escala espacial mais ampla, nem sequer a adesão a um paradigma teórico específico, implicando antes a existência de um conceito explícito e básico de Paisagem.

A noção de paisagem associada ao contexto arqueológico e definida através dos processos de percepção e apreensão se mostra como alternativa às análises desenvolvidas na Ecologia Cultural que, como visto, são baseadas fundamentalmente na noção de adaptação cultural e nos modelos da geografia quantitativa.

A Arqueologia Pós-Processual, movimento iniciado em meados dos anos 1980, engloba várias abordagens (Arqueologia Contextual, Estrutural, Cognitiva, Marxista, Fenomenológica). Segundo Shanks \& Tilley (1989: 8-9), a Arqueologia Pós-Processual não propõe uma nova maneira de fazer Arqueologia, mas desenvolve uma filosofia crítica desta, contestando a possibilidade de um conhecimento objetivo do passado. Questões associadas ao significado, simbolismo e subjetividade do comportamento humano e da cultura material romperam com as análises mais tradicionais até então utilizados pela Arqueologia e a Geografia.

Essas novas perspectivas observam que a paisagem não é constituída por um mero cenário onde se desenvolvem as relações humanas, mas que ela é, sim, constituída por significados e pelas ações sociais dos indivíduos que nela habitam. A Paisagem, como objeto de estudo, pode ser definida como a materialização das práticas sociais em termos espaciais ao longo do tempo (PARCERO-OUBIÑA et al., 2014). Assim, o espaço é um meio para a prática, sendo socialmente produzido, tendo como produto a paisagem.

Um exemplo disso é a monumentalização dessas práticas sociais alterando a configuração espacial a partir de mudanças estruturais na paisagem: formas arquitetônicas monumentais estão relacionadas ao controle de recursos, a diferentes formas de hierarquização social, presença de organização e complexidade. Portanto, a monumentalidade pode ser compreendida como uma expressão de gupos sociais específicos, ou seja, uma forma de reprodução social que introduz na paisagem descontinuidades artificiais (CRIADO-BOADO; MANAÑA-BORRAZÁS \& GIANOTTI, 2016: 114). Para Wendy Ashmore (2004: 262), "The 'afterlife of monuments' is not simply the physical formation of ruins, but integral to understanding landscape as social history". Tornando-se expressão de gupos sociais específicos

A paisagem arqueológica é vista como um conjunto de elementos dotados de significação, essencialmente dinâmicos dentro da experiência cognitiva humana, ou 
seja, um conjunto de elementos que atuam como signos, símbolos e mensagens interrelacionadas com a sociedade e com o indivíduo da época. Os significados, dessa forma, são compreendidos subjetivamente pelo pesquisador, como aquilo a que os indivíduos atribuem seus próprios atos, mediante consciência e compreensão (LAYTON \& UCKO 1999: 11 apud GARCÍA SANJUÁN, 2005: 245).

De acordo com Almudena Orejas (1995-96: 62):

La Arqueología del paisaje no es sólo mirar más allá del yacimiento o del texto literario, supone integrar, interpretar y comprender en un doble sentido: la lectura (o las lecturas) que nosotros hacemos hoy de un paisaje del pasado y la (o las) que de él hicieron las comunidades que lo construyeron.

A percepção da paisagem é um ato subjetivo, sujeito a interpretações e significados que podem variar de observador para observador. Há, portanto, uma aproximação entre a Arqueologia e a Geografia Cultural nessa abordagem que relaciona o espaço, a paisagem e a consciência. Se a Arqueologia da Paisagem é "uma resposta desde a Arqueologia ao problema do espaço", como afirma João Fonte (2015: 43), a questão a ser colocada aqui é: como se dão essas formas de consciência a respeito do espaço?

A paisagem é um produto sociocultural criado pela objetivação - sobre o meio e em termos espaciais - da ação humana tanto de caráter material como imaginário (CRIADO-BOADO, 1993a, 1999). Verificam-se, portanto, duas vertentes principais resultantes dessa relação sociedade/espaço: uma mais subjetiva do espaço, destacando a percepção, a sensibilidade, a vivência desse espaço; e outra mais objetiva do espaço, destacando o uso do solo, as atividades de produção, da distribuição de serviços, a representação desse espaço.

Em nossa concepção, essas duas vertentes não se opõem, mas se complementam. Deve-se, assim, procurar entender as inter-relações entre as comunidades humanas e o ambiente, que é onde a análise do uso do espaço assume importância fundamental. Ao invés de se estudar o espaço, deve-se priorizar a relação sociedade/espaço, pois é a sociedade que age, que se apropria e valoriza esse espaço. O espaço, portanto, é uma projeção dessa sociedade.

Segundo Moraes (1986: 43):

$\mathrm{Na}$ medida em que se aceita que os homens agem movidos por sua consciência [...], a questão da subjetividade emerge com importância na explicação do movimento das sociedades. A produção da História, poderse-ia dizer, passa pelas formas pelas quais os homens se veem no mundo, pelos seus valores suas crenças e concepções. O fluir da História se manifesta enquanto cotidianidade para seus agentes concretos. Por isso o fator subjetividade não pode ser desprezado.

A sociedade possui uma espacialidade, produto da apreensão de sua própria dimensão espacial, que se observa quando se buscam as relações existentes na sociedade, ou seja, as relações entre a sociedade e seu espaço.

Ainda segundo Moraes (2005: 15): 
O espaço produzido é um resultado da ação humana sobre a superfície terrestre que expressa, a cada momento, as relações sociais que the deram origem. Nesse sentido, a paisagem manifesta a historicidade do desenvolvimento humano, associando objetos fixados ao solo e geneticamente datados. Tais objetos exprimem a espacialidade de organizações sóciopolíticas específicas e se articulam sempre numa funcionalidade do presente.

A paisagem é, então, percebida como um produto material, cultural e histórico de um dado grupo sobre a qual existe uma rede de interações e todo um universo de elementos que são transmitidos de geração a geração. Ou seja, ela vai se configurar devido aos grupos estabelecidos ali. Essas interações não apenas envolvem a troca de bens materiais, mas também de informações, que compreendem ideias, símbolos, invenções, aspirações e valores (RENFREW \& BAHN, 2009: 191).

Dessa forma, são importantes tanto a definição de padrões no uso do espaço, quanto as inter-relações com a cultura material e a própria cultura, entendendo que os processos que influenciam o comportamento podem ser inferidos a partir do registro arqueológico (KENT, 1987: 2).

Em uma linha de pesquisa que tende mais à fenomenologia, Knapp \& Ashmore (1999: 10) propuseram três modelos de paisagem: constructed, conceptualized e ideational, considerando a paisagem como "[...] the arena in which and through which memory, identity, social order and transformation are constructed, played out, reinvented, and changed".

Devemos, então, ressaltar a paisagem como cenário ativo, implicado na dimensão socioambiental decorrente das manifestações e práticas humanas em profunda interação com seu entorno. Essa interação define as diversas formas de relação transformadoras do território. A partir dessas transformações efetuadas pelas intervenções antrópicas na paisagem, podemos interpretar a dimensão humana como apropriação criativa e real - nos territórios os quais os grupos modificaram e/ou adaptaram de acordo com suas necessidades.

Portanto, essa paisagem, percebida e compreendida pelo grupo que a ocupou, "possui características que são resultados de construções sociais a partir das relações dos fatores naturais/humanos e individuais/compartilhados, sendo identificadas dentro de evidências arqueologicamente perceptíveis" (SIMÕES, 2014: 28). Assim, a paisagem analisada pelo arqueólogo não é somente o ecossistema, mas um lugar pleno de assinaturas antrópicas que se sucedem no tempo. A paisagem deve ser observada como uma realidade dinâmica em transformação. De acordo com Gutiérrez Soler \& Bellón Ruiz (2001: 37-38), nos estudos arqueológicos, principalmente ligados à análise espacial:

[...] se ha marcado desde el comienzo la necesidad de avanzar en el conocimiento metodológico de nuevas técnicas dedicadas a la interpretación histórica y a la reconstrucción del paisaje como uno de sus principales objetivos.

Messias Passos (2006: 67-79) observa que analisar a paisagem do ponto de vista histórico é de fundamental importância, uma vez que, ao se analisar a paisagem 
não há como negar o nível de intervenção antrópica, marcas da história revelada nos usos e costumes, interesses e tradições.

Pode até ser que a "Paisagem" sofra um "efeito de moda", como afirma González Villaescusa (2006: 75): "El fetiche de los [años] sesenta 'economía', el de los setenta 'cultural', el de los ochenta 'mentalidad', ha sido sustituido por el fetiche 'ecología' o 'paisaje". O importante é que através desses distintos enfoques pode-se observar um esforço teórico na construção de um campo de saber científico por parte daqueles que fazem a Arqueologia, tanto faz a denominação que a ela seja dada: Arqueologia Espacial ou Arqueologia da Paisagem. O esforço nessa "teorização do método" (BARCELÓ, 1992) se mostrou extremamente necessário para o seu desenvolvimento.

Para concluir essa explanação teórica, fechamos com a definição dada por Palet Martínez (2005: 53), que assim define os estudos sobre o território e a renovação de métodos e técnicas da Arqueologia da Paisagem:

Des de la perspectiva d'aquests estudis, el paisatge forma un espai humanitzat, modelat per les societats al llarg del temps. Constitueix un espai viscuit i canviant, un element "cultural" producte $i$ expressió de les societats que l'han configurat. Les "formes" del paisatge estan carregades de significat històric i conserven les empremtes de l' impacte humà al llarg del temps.

De forma sintética, da junção das três dimensões essenciais - política, econômica e cultural - localizadas no tempo (História) e no Espaço (Geografia), surge o Território. Uma impressão do poder no espaço, territorializado e monumentalizado na paisagem pelo sujeito territorial (o Império Romano, idealizado e levado adiante pela sociedade), que é movido pela intencionalidade. Neste sentido, espaço, território e paisagem são fundamentais para a análise da "Romanização" na Península Ibérica, área rica em recursos naturais e humanos, motores dessa territorialização. Por conseguinte, a proposta do presente trabalho busca, por meio de metodologias e resultados que tentam demonstrar o elo de ligação entre o território investigado e a paisagem imaginada, o produto sociocultural. Como afirma Alfredo González Ruibal (2006: 19), (...) el objetivo de esta arqueología, como de las últimas tendencias postprocesuales, es repoblar un paisaje que los relatos arqueológicos han dejado vacío de gente.

\subsection{Enquadramento Metodológico - As Geotecnologias na interpretação da paisagem arqueológica}

Como apontado no início do capítulo, no presente trabalho optou-se por adotar preceitos teóricos e metodológicos fundamentados nos princípios da interdisciplinaridade a fim de melhor compreender os processos que resultaram na construção da Paisagem em estudo, o Noroeste Peninsular Romano, a partir do território de suas 
três capitais políticas: Bracara Augusta, Lucus Augusti e Asturica Augusta, de fundações da época do imperador Augusto.

De acordo com a linha de pensamento de Maurizio Forte (2002: 17):

Riteniamo che possa risultare di grande interesse [...] il confrontarsi con le applicazioni interdisciplinari [...]. Le esperienze interdisciplinari insegnano che solo attraverso analisi comparative è possibile ottenere significativi progressi scientifici e tecnologici e, comunque, per lo meno, un buon esito dei processi comunicativi.

O principal objetivo é demonstrar que o estudo da transição do mundo préromano ao romano e os dois primeiros séculos da presença romana no Noroeste Peninsular oferecem um panorama ideal para ser abordado pela denominada Arqueologia da Paisagem. As transformações que ali aconteceram não devem simplesmente ser observadas em termos de surgimento de novos estatutos, fundação de cidades ou mudanças onomásticas; mas, sobretudo, nas alterações nas relações entre as diversas comunidades, no interior destas, nas formas de ocupação, estruturação e contemplação de seu espaço, nas intervenções no território e nas formas antrópicas visíveis na paisagem.

De acordo com Forte (2002: 119):

La percezione del paesaggio archeologico è interpretabile attraverso una mappa mentale, ovvero attraverso un' alfabetizzazione digitale dell' insieme. Gli elementi connettivi, simbolici, naturali, social e antropici del territorio costruiscono la visione del paesaggio e il nostro orizzonte cognitivo.

Em geral, as informações provenientes de diversas áreas da pesquisa arqueológica podem ser utilizadas na Arqueologia da Paisagem. Segundo Chapman (2006: 12), "the combination of methods has often supplied the key to providing a wide range of clues, identifying the complex palimpsest of past activity that characterizes our landscape today".

Além do mais, abordagens como as utilizadas pela Arqueologia da Paisagem intervêm menos nos registros arqueológicos, mostrando que é possível reconstituir a maneira como populações pretéritas organizaram seus espaços com um mínimo de intervenção nos indícios por elas deixados, por intermédio das ferramentas de tecnologia geoespacial. Para Llobera (2011: 193), sua utilização deve ser entendida "as a way to extend archaeology in new directions and to recognize that the digital representation and treatment of archaeological information can generate new forms of doing archaeology". Maurizio Forte (2002: 17) também destaca que, pelo seu caráter interdisciplinar, "archeologia e beni culturali costituiscono forse il migliore territorio possibile di sperimentazione tecnologica, data la particolare complessità e multidimensionalità dei dati di afferenza". E complementa (2002: 23):

Per le informazioni che si trova a gestire, il GIS archeologico costituisce probabilmente il migliore contesto di sperimentazione rispetto ad altri ambiti applicative, soprattutto per due ordini di motivi: la multidimensionalità dei dati e la diacronia delle informazioni. 
Aqui optou-se por utilizar o termo "Geotecnologias" ao nos referirmos ao conjunto de tecnologias de informação geoespacial. Mas o que se observa é que, nas tentativas de sua definição, alguns conceitos são, geralmente, confundidos ou considerados similares, como, por exemplo, o uso dos termos "Geoprocessamento" e "Sistemas de Informações Geográficas" (SIG). Para Xavier da Silva (2009: 43), "existem sombreamentos ${ }^{28}$ entre esses ramos do saber, porém suas finalidades principais diferem".

Em diversas obras de Arqueologia, inclusive, se sobressai o uso do termo SIG (Sistemas de Informações Geográficas) nos títulos (como, por exemplo, em: ALLEN; GREEN \& ZUBROW, 1990; KVAMME, 1992; LOCK \& STANČIČ, 1995; CULLEN; KVAMME; JOHNSON; PETRIE, 1995; GILLINGS; MATTINGLY \& VAN DALEN, 1999; FORTE, 2002; WHEATLEY \& GILLINGS, 2002; CONOLLY \& LAKE, 2006). Mas o que se percebe nesses estudos é que eles correspondem, de fato, ao conjunto das Geotecnologias. Para Maurizio Forte (2002: 13), uma definição adequada do que ele chama de "SIG Cultural" ou "SIG Arqueológico" seria:

[...] un sistema e un modello spaziale di archiviazione ed elaborazione di dati, eventi ed attività spaziali, finalizzato all' interpretazione del paesaggio storico e archeologico, dal sito al território, dal costruito all' insediato, dalla microscala alla macroscala; [...].

Assim, o estudo da paisagem e do entorno dos sítios arqueológicos vem se firmando cada vez mais através do uso das chamadas geotecnologias e são muitas as vantagens de sua aplicação. A principal é a possibilidade de armazenamento, análise e representação de dados espaciais (PARKER, 1988: 1547), sendo um ferramental que consegue analisar espacialmente a informação e integrá-la com os conteúdos alfanuméricos (SALGADO, 2005: 2).

As geotecnologias, portanto, são o conjunto de ferramentas para coleta, processamento, análise e disponibilização de informação com referência geográfica; e compreende uma vasta gama de aplicações e de instrumentos utilizados para a manipulação e operação de dados que possuem interesse espacial, como, por exemplo: Cartografia Digital; Estação Total; GPS (Sistemas de Posicionamento Global); Scanner Laser; SIG (Sistemas de Informação Geográfica); Desenho CAD; Sensoriamento Remoto; LiDAR (Light Detection and Ranging) (SILVA, 2009: 40).

De acordo com Manuela Martins \& Paulo Bernardes (2000: 12), a adoção de novas tecnologias na Arqueologia - para ajudar a investigação, a gestão e a representação do passado - é uma consequência natural que resulta da necessidade de gerir enormes quantidades de dados arqueológicos e, também, da evolução rápida das novas tecnologias, cada vez mais adaptáveis ao processamento de informação arqueológica. Segundo José Luiz de Morais e Henrique Mourão (2005: 362):

a qualidade de Georreferenciar procedimentos, cenários ou sistemas regionais de povoamento lhe confere [ao SIG] um estatuto ímpar: a competência para tratar assuntos relacionados com o design da Arqueologia em sua dimensão de planejamento, gestão e manejo do patrimônio arqueológico.

\footnotetext{
${ }^{28}$ Sombreamentos no sentido de equivalências.
} 
É oportuno, nesse momento, elencar alguns exemplos de aplicação de geotecnologias em programas de investigação arqueológica. Em diversas pesquisas, e de maneira eclética, têm sido efetuados estudos de análise geoespacial em Arqueologia. As primeiras aplicações significativas apareceram nos anos 80 do século $X X$, com um grande incremento nos anos 90, principalmente direcionadas para a computação gráfica e para análises estatísticas. Uma de suas principais utilizações tem sido, desde então, as aplicações de modelos preditivos (SEBASTIAN \& JUDGE, 1988: 1-18; VAN LEUSEN, 1993: 105-124), que podem ser definidos como "partial representations of a theory and are formulated in a manner which enables the archaeologists to test the theory by means of empirical data" (VOORIPS, 1986: 251). Dessa forma, os modelos preditivos servem para testar hipóteses e experimentar teorias científicas nas diversas etapas da pesquisa (WARREN, 1990: 90-111). Esse tipo de abordagem prevê análises espaciais dos assentamentos através da elaboração de correlações estatísticas de componentes ambientais, tais como: pendência do terreno, elevação, solo, distância da água, relevo etc.

Podemos, também, destacar diversas conferências sobre o tema como a $C A A^{29}$ (Computer Applications and Quantitative Methods in Archaeology), com as publicações periódicas do Computing and Archaeology Newsletter, editadas pela Universidade de Oxford, onde se pode encontrar informação abundante sobre a maioria dos trabalhos realizados nesse âmbito. Outra publicação, com objetivos mais gerais, é a Archeologia e Calcolatori, editada em Roma pelo Instituto per l'Archeologia Etrusco-Italica del Consiglio Nazionale delle Ricerche e pelo Dipartamento di Archeologia e Storia delle Arti dell' Università degli Studi di Siena.

$\mathrm{Na}$ Espanha têm-se realizado diversos projetos, tanto de investigação como de gestão patrimonial, que podem ser inseridos nessa temática. É importante fazer referência aos volumes 9-10 da revista Arqueología Espacial, dedicados à Arqueología del Paisaje, tema do "Vo Colóquio Internacional de Arqueologia Espacial", realizado pela Escola de Jaén em Teruel, em 1998. Em 1999, a Universidad Autónoma de Madrid publicou uma importante coletânea de artigos sob o título Los S.I.G. y el análisis espacial en Arqueología (BAENA; BLASCO \& QUESADA, 1999). Também não se pode deixar de mencionar os importantes trabalhos realizados pela equipe de Felipe Criado-Boado (1999, 2016), como os de Pastor Fábrega-Álvarez $(2006,2011)$ e João Fonte $(2011,2015)$, membros do Instituto de Ciencias do Patrimonio ${ }^{30}$, com sede em Santiago de Compostela, que tem contribuído muito para a divulgação da abordagem da Arqueologia da Paisagem e da aplicação de tecnologias geoespaciais para Arqueologia e Patrimônio. E, por fim, a pesquisa de Ignasi Grau Mira (2006), do Grupo de Investigação "Arqueología y Patrimonio Histórico", da Universidade de Alicante.

A incorporação das geotecnologias à Arqueologia adquiriu grande evidência com a publicação dessas pesquisas, que rapidamente se tornaram obras de referência básica. Elas fornecem uma gama considerável de casos de estudos e discussões teóricas juntamente com uma panorâmica do desenvolvimento das geotecnologias em Arqueologia.

${ }^{29}$ Que publicou o primeiro paper sobre SIG em 1986.

$30 \mathrm{O}$ Instituto de Ciencias do Patrimonio (Incipit), anteriormente conhecido com as denominações "Laboratorio de Patrimonio" (LaPa) e, também, "Laboratorio de Arqueoloxía da Paisaxe" (Lar), no Instituto de Estudos Galegos P. Sarmiento, do CSIC. 
Sem dúvida essas ferramentas geotecnológicas têm uma enorme potencialidade na documentação, estudo e gestão das paisagens culturais antigas. Todavia, devemos ter em mente que são ferramentas potencialmente úteis das quais podemos nos utilizar para atingir alguns objetivos, mas os seus resultados podem e devem ser verificados com outras formas de análises e interpretações. Esse ferramental geotecnológico serve, portanto, para o investigador atingir os objetivos propostos em sua metodologia de pesquisa e não um fim em si mesmo, já que se trata de mais um recurso para a análise e interpelação dos dados, divulgados, principalmente, na forma de mapas. Dessa forma, é importante ter em mente a conhecida metáfora de Alfred Korzybsky (1941): "o mapa não é o território". Ou seja, o mapa representa e codifica o território. E essa leitura é bem ilustrativa para o profissional, entre eles o arqueólogo, que "realiza constantemente el esfuerzo de cambiar sus aproximaciónes desde el mundo tangible hasta sus representaciones gráficas y viceversa" (GUÉRIN, 2006: 13).

Segundo os arqueólogos ingleses Conolly \& Lake (2009: 69):

El aparente "conocimiento totalizador" que emerge en el SIG a partir del conjunto de estructuras, campos, hidrología, suelos, alturas y evidencia arqueológica existente no permite comprender directamente el paisaje social más importante. Las interpretaciones significativas y sustantivas de las relaciones complejas y casi siempre impredecibles que tienen los humanos con sus respectivos paisajes no se pueden aprehender con la sola recogida de datos, sino que se han de construir y explorar minuciosamente utilizando distintas fuentes (etnográficas, históricas, medioambientales, vivenciales, arqueológicas). Todas y cada una de esas fuentes ofrecen perspectivas y posibilidades interpretativas para mejorar nuestro conocimiento del comportamiento humano del pasado en un determinado paisaje; el SIG no es más que una de varias herramientas potencialmente útiles que pueden utilizarse para lograr ese objetivo, y sus resultados deberán cotejarse con otras formas de análisis e interpretaciones.

É nesse sentido que pretendemos aplicar uma metodologia de estudo utilizando o ferramental geotecnológico interagindo com outras fontes disponíveis, tais como: fontes textuais, itinerários, epigrafia, miliários, pontes, dados ambientais e arqueológicos. As geotecnologias permitem integrar o conhecimento geográfico com o conhecimento arqueológico e historiográfico. Além do mais, a disponibilidade de cartografia em formato digital avançou de forma surpreendente nos últimos anos, principalmente em território espanhol ${ }^{31}$. Esses aspectos citados acima viabilizam uma análise mais integrada das redes viárias antigas, em particular dos itinerários que ligavam o Noroeste Peninsular Romano, pois são grandes eixos com uma influência persistente na morfologia histórica.

O estudo da rede viária romana, e da epigrafia a ela associada, permite elucidar as orientações da ocupação territorial. Os vínculos físicos observáveis - elementos básicos na organização do território - conectam pontos fixos que possuem referência geográfica. Dessa forma, com os recursos do ferramental geotecnológico, procurou-se

\footnotetext{
31 O Centro Nacional de Información Geográfica (CNIG) disponibiliza diversos dados espaciais digitais de caráter geográfico gerados pela Dirección General del Instituto Geográfico Nacional (IGN). Esses dados espaciais estão disponíveis em: http://centrodedescargas.cnig.es/CentroDescargas/index.jsp
} 
analisar o atrelamento de usos do território a interesses do poder romano, a partir da conquista, no Noroeste Peninsular.

As vias romanas foram obras de engenharia que serviram de eixo "Romanizador", ou seja, de integração: a coesão territorial, a estruturação econômica e a disseminação de ideais políticas, artísticas e religiosas fluiram através dessas vias. Nesse processo integrador era fundamental que o conquistador chegasse a várias partes do Império de modo a conseguir controlar os recursos materiais e humanos do novo território. Para isso, fazia-se necessário estabelecer uma rede viária que ligasse as civitates, os castros, os vici e as villae com as zonas mineiras e de exploração de recursos. Dessa forma, além de sua primeira origem militar, essas vias de comunicação eram obras públicas com uma clara finalidade econômica.

Segundo Helena Carvalho (2008: 260),

A estruturação de uma rede viária articulada constitui um processo decisivo na organização da paisagem. Funcionando como um esqueleto, as vias garantiam, na época romana, a defesa e afirmação do poder de Roma sobre os territórios conquistados, estabelecendo ligações, a escalas variadas, entre os principais aglomerados populacionais. Articulavam núcleos urbanos e regiões, mas promoviam, também, a ligação entre as cidades e os territórios adjacentes. As vias constituem, portanto, uma das principais entidades reguladoras da paisagem e das relações cidade-campo.

Objetivou-se nessa pesquisa, portanto, estudar a lógica da criação de diferentes vias de comunicação que uniram os núcleos romanos principais entre si ou com lugares de interesse estratégico ou econômico para a administração romana, tendo como ponto de partida as três capitais políticas do Noroeste Romano Peninsular: Bracara Augusta, Lucus Augusti e Asturica Augusta.

\subsection{Atual situação dos estudos sobre a "Romanização" do Noroeste Peninsular - uma aproximação pós-colonialista}

A Península lbérica é uma região chave que tem o potencial de transformar nosso conhecimento sobre o processo de conquista romana já que possui algumas especificidades que não ocorreram em outras regiões conquistadas. A precocidade dos primeiros contatos romanos no território, a longevidade da presença romana ali, a enorme diversidade geográfica de suas regiões e a diferença cultural entre os povos a faz ideal para o entendimento da gênese, do desenvolvimento e da desintegração do Império romano como um todo.

De acordo com Fabião (2001: 110):

[Isso] implicou inúmeras situações peculiares, próprias de uma longa convivência e interacção, ora conflitiva ora pactuada, entre romanos e indígenas que, progressivamente, forjou complexos fenómenos de assimilação cultural. 
Quando se estuda o Império Romano, principalmente sua periferia, o pesquisador precisa, muitas vezes, lidar com um conceito muito controverso que ainda vem sendo alvo de debates cada vez mais intensos: o de "Romanização". Entretanto, apesar de controverso, ainda é muito utilizado pelos estudiosos do império romano, haja vista que um dos temas dominantes da arqueologia provincial romana tem sido a questão da mudança cultural no contexto do império romano. Dessa forma, a arqueologia romana gira em torno do tema da "Romanização" (REVELL, 2009: x, 5).

Essa característica pode ser observada principalmente na Península Ibérica, onde os estudos sobre as realidades sociais do Noroeste peninsular foram direcionados por uma noção de "Romanização" entendida como o processo de "desaparecimento ou transformação de estruturas indígenas frente às estruturas do sistema romano" (MANGAS, 1992: 208).

Muitos desses estudos centraram-se na evidência da transformação cultural, ao explorar os mecanismos pelos quais tais mudanças ocorreram, e ao lidar, principalmente, com o período de transição inicial (REVELL, 2009: ix).

O problema aparece quando se constata que esse processo se entende como uma substituição das realidades indígenas pelas romanas. Aqui, o elemento de referência normalmente utilizado é o próprio modelo de sociedade romana, de modo que o processo é visto como uma evolução gradual em direção ao estabelecimento de sociedades "romanas" organizadas e sujeitas às mesmas relações sociais que as desenvolvidas em Roma. Segundo Louise Revell (2009: ix), esse debate adotou uma homogeneidade idealizada entre e dentro de cada uma das sociedades resultantes após esse período de transformação.

A ideia de "Romanização" compreende um conceito construído na virada do século XIX para o XX, relacionado a consolidação dos Estados Nacionais, ao auge das teorias evolucionistas, e ao momento de expansão imperialista. Essa ideia ("Romanização") atuaria como um discurso de dominação que demostraria historicamente o caráter civilizado dos europeus e a barbárie congênita dos povos colonizados (CRESPO MAS, 2008).

De acordo com Norma Musco Mendes (2007a: 2):

Na historiografia de fins do século XIX e inícios do século $X X$ são evidentes os paralelos entre o Império Romano e aqueles construídos pelas potências imperialistas do mundo moderno.

A experiência imperialista romana foi apropriada pelos discursos ideológicos das potências coloniais, que a utilizaram para justificar e legitimar o direito de conquista, vinculando a ação imperialista da Inglaterra, França, Itália como herdeiras de Roma e como uma forma legítima de disseminar entre os nativos o que os Romanos chamavam de civilização.

Estudiosos, influenciados pelo contexto da época, "deram ao termo o sentido de evolução moral, de passagem da barbárie para a civilização" (SILVA, 2011: 58). Autores como Christian Matthias Theodor Mommsen (1874) e Francis Haverfield 
(1905-1906) $)^{32}$, ajudaram a desenvolver essa ideia de que a adoção de padrões culturais romanos era algo positivo, sinal de progresso para os povos conquistados. Segundo Hingley (2005: 34), o processo de "Romanização possuía efetivamente uma qualidade espiritual" para esses autores citados acima. Para Pereira-Menaut (2009: 17),

A mediados do século XIX, cando nacen o concepto e a palavra, é xeral a convicción de que a misión de Roma, a propagación da civilización e o progresso, o dereito, etc. converten a romanización nunha tarefa de alcance universal, que libraría os homes e as nacións romanizados do seu ancestral atraso, ignorância, pobreza e incultura.

Uma das visões existentes sobre o império romano é a de que, em todo o seu território, se desenvolveu o mesmo modelo de organização social que, a cada momento e, dependendo da área, se encontrava em diferentes estágios de desenvolvimento. Estes abrangiam uma ampla gama de graus, desde o "modelo" finalizado (Roma) até os das áreas marginais e periféricas, que nunca se romanizariam ou o fariam apenas superficialmente.

Para Broughton (1959: 645-651):

Discusión of romanization in any province of the Roman Empire involves study of a complicated nexos of physical, social, economic and cultural factors, such as regularly appear in the relations o fan imperial people and system whith indigenous cultures at different levels of development.

'O fundamento para esse tipo de "Romanização", como substituição de estruturas sociais pré-romanas, é a cidade clássica, considerada como principal divulgadora das estruturas sociais romanas e elemento essencial para o enquadramento das elites locais cujo acesso à cidadania é inadimissível sem uma adequação ao padrão urbano. De acordo com essa interpretação, a facilidade de integração ao modelo romano dependia, sobretudo, das organizações indígenas préromanas. Por exemplo, algumas, como no sul e no leste da Hispânia, por terem desenvolvido um complexo sistema social urbano e terem sofrido influência de imigração itálica, foram mais facilmente romanizadas. Outras, no entanto, mais periféricas e com formas de organização social "menos desenvolvidas", foram romanizadas superficialmente ou não foram' (SASTRE PRATS, 1999: 20-21).

G. Alföldy (1989: 146), sobre o início do Principado, diz:

Observando em seu conjunto, portanto, pode-se dizer que o império romano estava regulado por um sistema económico e social unitário, no sentido de que este sistema, diferente de acordo com províncias ou regiões, ou foi totalmente implementado ou, pelo menos, representava a linha de tendência no processo de desenvolvimento económico e social local, sem uma visão de aparecimento de modelos alternativos claros dessa tendência dominante.

\footnotetext{
32 MOMMSEN, Th., Römische Geschichte IV, Berlin: [s.n], 1874; HAVERFIELD, F., The Romanization of
} Britain. Proceedings of the British Academy, Londres: Oxford, 1905-1906. 
Portanto, a "Romanização", tradicionalmente, era vista como um processo unidirecional e unívoco que não contemplava a complexidade das culturas indígenas e a diversidade de contextos e de experiências (JÍMÉNEZ DÍEZ, 2008: 37-57).

Nos estudos sobre a "Romanização" do Noroeste Peninsular, inevitavelmente, um dos pontos de vista difundido leva em consideração que alguns territórios imperiais apresentavam formas simples de organização social (um "subdesenvolvimento") frente a um "mundo desenvolvido" que consistia em Roma e algumas províncias (SASTRE PRATS, 1999: 21).

Para Cruz (2014: 408),

Apresenta-se então a Romanização do Noroeste como algo coerente com a definição preconcebida das comunidades proto-históricas: a inexistência de cidades romanas no seu sentido mais clássico, que mais não seriam do que "castros romanizados", adaptados a comunidades que refletiam séculos de isolamento, de autarcia, de subsistência e de permanente adaptação a um meio geograficamente inóspito.

Paralelamente, a constatação de traços culturais ou elementos sociais não romanos no interior dessas comunidades pouco urbanizadas leva a se considerar uma permanência de determinados elementos culturais precedentes, sobreviventes de realidades sociais de caráter residual que são, evidentemente, elementos de tradição indígena pré-romana, mas já enquadrados num contexto cultural distinto. Um exemplo disso, no caso da Hispânia, são os genitivos plurais documentados na epigrafia da Meseta, do Norte e do Noroeste: o sinal epigráfico do C invertido, o o galaicoastúrico, interpretado como castellum ${ }^{33}$ ou castro (ALBERTOS FIRMAT, 1975; PEREIRA-MENAUT, 1983; GONZALEZ RODRIGUEZ; SANTOS YANGUAS, 1994; (SASTRE PRATS, 1999: 21; SANTOS YANGUAS, 2009).

Apesar de aparecer em um tipo de suporte romano como a epigrafia e estar presente, em alguns casos, até o final do Alto Império, foram desenvolvidas interpretações reducionistas, elaboradas a partir de uma perspectiva romana. A tendência tem sido desenvolver interpretações históricas que expliquem seu papel no contexto pré-romano já que, de maneira geral, não se considera que tenham tido um papel relevante no âmbito das Civitates (SASTRE PRATS, 1999: 21-22).

Percebe-se, assim, que toda pesquisa histórica não é neutra, sendo fruto do momento histórico em que ela é realizada. Portanto, o arqueólogo, assim como o historiador, são frutos de sua sociedade e de seu tempo e, quando estudam o passado, não abandonam sua contemporaneidade. Cabe então, ao pesquisador, não apenas estar ciente dessa carga contemporânea, mas, principalmente, munir-se da metodologia e das teorias adequadas para que seu estudo, sua reconstrução, seja relevante. Como afirmou Clarke (1973: 6), "The loss of disciplinary innocence is the price of expanding consciousness; certainly the price is high but the loss is irreversible and the prize substantial".

${ }^{33}$ Castellum era o termo pelo qual os romanos se referiam aos povoados fortificados - castros - das populações pré-romanas do Noroeste Peninsular. 
$\mathrm{Na}$ presente pesquisa, a Arqueologia é compreendida como prática social, discursiva e interpretativa, condicionada por múltiplas variáveis. Como apontou Ruiz Zapatero (2003: 218), não existe Arqueologia sem uma produção historiográfica crítica:

La interpretación del pasado arqueológico no sólo reside en los datos arqueológicos sino también en todo lo escrito para interpretarlos, de manera que lo interpretado previamente forma parte inevitable de la nueva interpretación a construir. La historiografía es también material de construcción, material sin el cual no es viable la producción crítica de nuevo conocimiento histórico sobre el pasado.

Por isso, o conceito tradicional, e insuficiente, de "Romanização", que se vincula ao conceito de aculturação usado pela Antropologia em inícios do século XX e que "tem sido alvo de debates ${ }^{34}$, tanto na História quanto na Arqueologia, não pode mais ser utilizado sem que se faça uma definição ou determinação do seu emprego em determinado contexto" (SANTOS, 2006: 18).

Com o desenvolvimento das pesquisas alcançaram-se avanços importantes na compreensão desse processo. Por um lado, a proliferação de trabalhos de escavação e prospecção trouxe uma bagagem documental que levanta novas interpretações. Nesse sentido, as últimas décadas foram de desenvolvimento de trabalhos de prospecção e análises de povoamento e paisagens arqueológicas, seguindo a linha de pesquisa anglo-saxônica dos estudos de paisagem. Por outro lado, as correntes teóricas de vertente antropológica, denominadas "pós-coloniais", revisam os modelos de contato intercultural e os princípios de dominação imperial que aparecem nas posições teóricas tradicionais para propor novas hipóteses sobre o Império Romano entidade complexa, não uniforme em sua extensão territorial e com uma enorme diversidade cultural. Para Santos (2006: 20),

Hoje se questiona a diversidade dessa "Romanização" e quão diversas eram as províncias, qual era a intenção dessa "Romanização" e os sinais de resistência a ela, sua grande variação pelo Império.

De acordo com essas perspectivas teóricas, a "Romanização" é percebida como um "sistema estruturado de diferenças" (WOOLF, 1998: 310), no qual as comunidades indígenas conservam determinadas tradições culturais, reelaborando-as e adotando outras. Tal postura serve para diferenciá-las do resto da "população romana" do império, afirmando-se as individualidades e originando formas culturais híbridas, formando-se uma identidade múltipla, fruto da interação cultural entre indígenas e romanos, de experiências discrepantes, e não da mera aculturação/romanização desses indígenas (MATTINGLY, 2004).

Muitas dessas ideias, desenvolvidas sobretudo por Greg Woolf (1998), trazem o sentido da "Romanização" como uma primeira "globalização", embora ainda persistam determinados traços culturais locais e regionais. Woolf (1998: 7), ao partir de uma frase de Harris (1971: 147), define "Romanização" como:

\footnotetext{
${ }^{34}$ Alguns autores que criticam esse modelo de "romanização" são: Keay \& Terrenato (2001); Abad Casal (2003); Bendala Galan (1981, 1987, 2000); Mattingly (2004, 2011) e Revell (2009).
} 
Romanization may have been 'the process by which the inhabitants come to be, and to think of themselves as, Romans', but there was more than one kind of Roman, and studies of provincial culture need to account for the cultural diversity, as well as the unity, of the empire.

Segundo Revell (2009: x), ao invés de uma identidade fixa, deve-se pensar em "romano" como um discurso de possibilidades, que pode ter uma miríade de interpretações potenciais. Entretanto, ao mesmo tempo, certos elementos eram comuns a sociedades romanas.

Esse contexto de reelaboração dos estudos sobre a "Romanização" tem influenciado as pesquisas arqueológicas em terras hispânicas (KEAY, 1990, 1996 e 2001). No capítulo "Romanization and the Hispaniae", do livro Italy and the West: comparative issues in Romanization (KEAY \& TERRENATO, 2001), Simon Keay (2001: 124) apresenta uma visão recorrente da presença romana na Península Ibérica, ressaltando que o ambiente encontrado pelos romanos era altamente complexo, uma vez que a realidade arqueológica sugere que os povos do sul e da costa leste da Ibéria haviam sido influenciados, de certa forma, por um amplo desenvolvimento cultural e político em curso em outros lugares no Mediterrâneo, como, por exemplo, a orientalização, urbanização nos modelos fenício e grego e a disseminação da escrita.

Seria este "ruído" de fundo, extremamente complexo, o responsável por moldar a dinâmica da "Romanização" na região, dando origem às suas peculiaridades. Seguindo essa linha interpretativa atual, uma das principais inovações é reestabelecer o papel desempenhado pelas sociedades nativas, percebendo-as como agentes ativos nesse processo de interação cultural e não enquanto "atores" inconscientes influenciados de forma passiva por fatores e/ou forças externas (GRAU MIRA, 2006: 212). É possível que esse processo tivesse permitido que as comunidades indígenas fossem capazes de se adaptar ao processo de expansão imperial romana aproveitando as vantagens dos seus novos contextos, nomeadamente através do desenvolvimento de determinadas aspectos das suas identidades preexistentes e dos recursos dos seus territórios (HINGLEY, 2005: 102-105).

Ainda, segundo Hingley (2005: 47):

Becoming Roman in this way allows for both the imperial context of social change and the local adoption of this identity to co-exist. Influential people are seen to have been keen to adopt Roman culture because this helped them to negotiate their own power simultaneously in local and in imperial contexts. [...] It was also in the interest of the Roman administration actively to promote the adoption of Roman ways among provincial elites, because these were the people at the very core of the local self-government who created the stability of relations that we term the empire of Rome.

Esse campo de análise permite enfatizar debates que giram em torno das ideias de emergência de identidade, ou seja, de "resistência", "assimilação" e "síntese" no mundo provincial romano e, também, propicia uma reavaliação da historiografia tradicional. 
Contudo, apesar da escola pós-processualista ter trazido mudanças fundamentais para a interpretação da evidência material (REVELL, 2009; CRESPO MAS, 2008), algumas críticas surgiram. Uma delas é que esse debate desencadeou uma fragmentação de abordagens ${ }^{35}$ sobre o tema da "Romanização". Pereira-Menaut (2009: 19), faz uma crítica a essa fragmentação, que ele denomina de "romanizações parciais":

(...) nos encontramos ante unha tendencia manierista (...) entendida como un buscado xogo de afiados conceptos, gusto polos paradoxos e as figuras retóricas, que ao cabo parecen levarnos a outro mundo sem saír deste. Non é estraño que no moderno debate se propuxese o abandono da palabra "romanización" e como, de momento, non hai un substituto de uso doado, alguns falan agora, na investigación anglosaxona, de "R-word", esa palavra que empeza com "r" e que, como ninguén sabe xa que significa nin que ten detrás e arrastra consigo, será melhor esquecer.

Para Pereira-Menaut (2009: 19-20), se houve ou não uma "romanização" na Galícia trata-se de uma questão semântica, cujo resultado depende do que cada um quer entender por "Romanização". E propõe utilizar em seu lugar a seguinte expressão: "transformacións producidas pola conquista romana e os seus resultados". A justificativa é que essa expressão ampla engloba duas realidades fundamentais: 0 transformado (o mundo indígena pré-romano e suas ações) e o transformante (os romanos e suas ações).

Na presente pesquisa, entendemos o termo "Romanização" como um processo de integração, que leva a formação de múltiplas identidades. Mas, de forma geral, optamos por utilizá-lo entre aspas por questão de comodidade.

Louise Revell (2009), prefere utilizar o conceito de "Romanidade" [Roman-ness]. Este conceito engloba ideias partilhadas, ideologias que de alguma maneira possam se diagnosticadas como "romanas". This broad discourse of Roman-ness moves the question of an ethnic identity beyond the model of elite-driven Romanization and problematic non-elite emulation (2009: 192).

Apesar de não serem idênticas no tempo e no espaço, a variabilidade dessas ideologias exploram várias maneiras de ser romano no Império. Assim, a forma como o império era sentido ou vivido também variava. Para Vasco Gil Mantas (2013: 12), (...) a Romanidade deve ser considerada como o resultado de uma política de integração centrada em padrões de comportamento e valores oficiais em que as diferenças se esbatem, sem que deixem de existir.

Revell (2009) define três áreas que podem identificar uma ideia compartilhada de "Romanidade": a urbanização, o papel do imperador e a prática religiosa. Para a autora, ser "romano" é um discurso, um projeto que cada pessoa entende de uma forma diferente. Este discurso era expressado através dos materiais utilizados e dos espaços habitados (2009: 189-191).

Aqui é interessante apresentar a abordagem do geógrafo Torsten Hägerstrand quando trata do tema difusão da inovação. Em seu texto intitulado "The propagation of

35 Como, por exemplo: Discrepant Experience (Mattingly 2006), Creolization (Webster 2001, 2003) e Agency (Barrett 1997; Revell 1999; Gardner 2002). 
innovation waves" (1962), Hägerstrand afirma que a difusão de uma inovação se propaga em duas dimensões: a espacial e a social. O tempo da inovação pode ser definido como um tempo 'empiricizado' 36 em um lugar (ou cultura material) que produz uma escala de império local. Ao se difundir, essa inovação aumenta a escala de império e, consequentemente, a condição de dominante. A ação pode criar instabilidade e conflitos entre os agentes e, portanto, novos limites. Como afirma Simon Keay (2001: 180), o Império estava em "um estado de mudança constante".

Segundo João Fonte (2009: 26):

Neste novo contexto, as elites indígenas detêm um papel fulcral, actuando como intermediárias entre as comunidades indígenas e a administração romana, sendo esta habilidade social que lhes confere novas formas e oportunidades de negociação do poder.

Deve-se, portanto, valorizar o papel desempenhado pelas elites nativas, através da negociação social e identitária, em sua vontade de manter seu papel dominante no seio da sociedade aproximando-se do conquistador e dominador social (MILLETT, 1990), ou mesmo a adaptação de estratégias de controle e assimilação de grupos nativos diversos, o que foi denominado por Terrenato (1998: 23) de Cultural Bricolage, para expressar um mosaico de elementos em um processo que tende à unificação:

This may be an appropriate term to describe a process in which new cultural items are obtained by means of attributing new functions to previously existing ones. For instance, the archaic system of élite alliance and interaction was transformed and made to serve a new purpose with imperial integration of the Italian aristocracies. As a consequence, the result of the process resembles a collage: that is a complex patchwork made of elements of various age and provenance: some of them are new, but many others are old objects, refunctionalized in new forms and made to serve new purposes within a new context. (TERRENATO, 1998: 23).

Outro ponto de destaque é a interpretação dos vestígios materiais que, nessa conjuntura, deve levar em conta que os objetos podem ser vistos de várias maneiras, dependendo de quem os faz. Para João Fonte (2009: 25-26),

É impossível sustentar a existência de uma cultura romana "standard" e "superior" adoptada da mesma forma pelas populações conquistadas, sendo perceptível no registo arqueológico uma "resistência" à mudança através da cultura material, que se resignifica através de determinados referentes identitários, manifestando-se uma forma concreta de estar e de ser no mundo.

Esses estudos sobre "Romanização" trazem à tona a questão das resistências ou negociações autóctones frente ao poder imperial romano. Autores como Mattingly,

\footnotetext{
${ }^{36}$ Milton Santos (2008) também apresentou uma proposta de 'empiricização do tempo' ao comparar tempo e espaço e possibilitar a datação dos lugares. Para Santos, ao tratar do tempo e do espaço em conjunto, é necessário utilizar como parâmetro a comparação. Sendo o espaço concreto, é essencial que o tempo também o seja. Realiza-se, portanto, a "empiricização" do tempo, concreto, ou seja, que pode ser realizado através das 'técnicas' - a "empiricização do tempo pela técnica" (2008: 25).
} 
Alcock, Webster e Whittaker (MATTINGLY, 1997), cujos textos enfatizam essa problemática, são expoentes dessa discussão. De modo geral, eles buscam uma abordagem que compreenda a complexidade das relações de poder. Segundo Mattingly (2011: 206), a identidade está relacionada com a questão do poder na sociedade romana e a criação das identidades provinciais não pode ser vista isolada das negociações de poder entre o Império Romano e os povos conquistados.

Para Alonso-Núñes (1989: 8):

Es obvio que hay que contar con una resistencia de los indígenas y de lo avanzado del proceso de asimilación de los pueblos indígenas (de la romanización en el caso de Roma) se puede juzgar del éxito o fracaso de la potencia agresora (Roma en nuestro caso). Se puede considerar como índices para proceder a tal evaluación el grado de supervivencia del nacionalismo indígena y la actitud de los pueblos sometidos hacia el poder central. Se puede decir que Roma triunfó plenamente en la Península Ibérica, de lo que es una muestra que Hispania llegó incluso a dar emperadores a Roma (Trajano, Adriano, Teodosio); se puede también afirmar que Hispania terminó identificándose con Roma.

Portanto, a atuação de Roma na nova organização territorial e administrativa não foi uniforme, nem a resposta ibérica ante a sua presença. Como em todo processo de transformação, determinados territórios e setores da população se beneficiaram com a presença romana enquanto outros saíram claramente prejudicados. Assim, enquanto a maioria dos centros ibéricos se revitalizava, outros, que gozavam de um forte poder no período anterior, foram destruídos ou abandonados. Para Grau Mira (2006: 223):

No cabe duda que el avance de la época romana incorporaría nuevas innovaciones y modificaciones en el modelo espacial, como la desaparición de los tradicionales oppida en los inicios del Imperio o el establecimiento de asentamientos tipo villae.

Dessa maneira, alguns questionamentos podem ser levantados: como se relacionam as mudanças na paisagem com o processo de socialização e "Romanização"? De que forma é utilizada a estrutura da paisagem na construção de significados?

Para Schama (1996: 26), "as paisagens podem ser conscientemente concebidas para expressar as virtudes de uma determinada comunidade política ou social". Exemplo disso é o Aedes Augusti, templo dedicado à memória do imperador Augusto que estava implantado no ponto mais alto da colina de Asturica Augusta.

Alguns fatores podem ser observados nessa "Romanização" visual promovida a partir de Augusto nas províncias romanas, como por exemplo: "(1) Urban planning, (2) Stylistic options, (3) elite patronage, and (4) imperial iconography compromised the larger Augustan concern for creating visual homogeneity" (MIERSE, 1999: 91).

Dessa forma, a arte e a arquitetura também eram utilizadas pelos romanos como formas de influência cultural e ideológica (KEAY, 1997: 195). Segundo Norma Musco Mendes (2006: 239-40): 
A territorialização do espaço e a construção da paisagem imperial significam um espaço delimitado sobre o qual se exerce o poder de uma entidade política, administrativa e judiciária, ou seja, uma forma de apropriação, intervenção e ordenação do espaço que se fundamenta nas relações de dominação e autoridade.

Esse processo de "Romanização/Romanidade", ou seja, transformações produzidas pela conquista romana e os seus resultados, com suas implicações sócioespaciais, deve ser analisado de modo a se compreender a construção de paisagens culturais que foram sentidas de diferentes formas, em cada período, pelas comunidades locais. Esse novo processo de territorialização provocou, provavelmente, um incremento potencial do conflito e desigualdades sociais.

No Noroeste Peninsular, apesar de evidências de materiais romanos já em finais do século II a.C., o processo denominado tradicionalmente como "Romanização" - que se realizou em longo termo e esteve dotado de múltiplas manifestações - se evidencia a partir da época de Augusto; a partir de então percebe-se uma rápida integração com o restante do império (WOOLF, 1998; DOPICO CAÍNZOS, 2006, 2009, 2016; REVELL, 2009). 


\section{CAPÍTULO 2. CONTEXTUALIZAÇÃO HISTÓRICA - A CONQUISTA}

O interesse de Roma pela Península Ibérica está diretamente relacionado a eventos históricos que desencadearam a Segunda Guerra Púnica, como, por exemplo, o casus belli da quebra do "Tratado do Ebro". Segundo as fontes textuais antigas, esse Tratado, assinado por Asdrúbal em 226 a.C., delimitava as fronteiras de Roma e Cartago. Sancho Royo (1976: 77), ao analisar o texto de Políbio, observa que "[...] esto no fue un verdadero 'tratado', sino simplemente un 'acuerdo', un 'pacto' o 'convenio' local". E complementa: "El Tratado o acuerdo del Ebro no fue un verdadero tratado desde el punto de vista jurídico y formal, y sí un acuerdo o un convenio entre Roma y un general cartaginés con plenos poderes para ello" (1976: 110).

Provavelmente, o interesse de Roma na região tenha sido incentivado por Massília (atual Marselha), sua aliada. Entretanto, já poderia existir uma preocupação com o crescente poderio cartaginês, haja vista que "em 231 a.C. uma delegação de senadores apresentou-se a Amílcar para o inquirir sobre o motivo das suas agressivas campanhas, e ouviu a resposta de que eram necessárias para que Cartago conseguisse pagar a indemnização a Roma" (GOLDSWORTHY, 2009: 183).

Para Blázquez (1962: 3-4):

Probablemente Roma en esta fecha (226) tampoco había establecido directa-mente relaciones económicas o de tipo político con los pueblos hispanos situados al N. de dicho río, pero se proponía, además de seguir favoreciendo a su aliada Marsella, que contaba en la costa catalana con una cabeza de puente tan importante como Ampurias, poner un límite a la expansión carta-ginesa en Hispania, que Roma misma había autorizado, al admitir de Amílcar, en el año 231, la excusa de que las conquistas en la Península eran motivadas por la necesidad de pagar la indemnización de guerra de la primera guerra púnica, fijada en 3.200 talentos a entregar en diez años.

A tomada de Sagunto, oppidum ${ }^{37}$ ibérico aliado de Roma e ponto máximo da fronteira norte entre Roma e Cartago, teria desencadeado a Segunda Guerra Púnica (218-202 a.C.) que, segundo Tito Lívio (XXI, 1), foi a "mais memorável de todas as guerras jamais acontecidas, a que, sob o comando de Aníbal, os cartagineses moveram ao povo romano". Ela teve como cenário a Hispânia, o sul da Gália, Itália, Sicília, Numídia e África. O conflito ocorreu no único espaço geográfico que sobrava aos cartagineses para alcançar a Península Itálica depois de terem perdido, em 241 a.C., o direito de transitar pelo estreito de Messina, entre a Sicília e o sul da Itália.

A presença de Roma na Hispânia se inicia em 218 a.C., a partir do desembarque das tropas romanas, comandadas por Cneu Cornélio Cipião Calvo, em Emporion

\footnotetext{
37 Tradicionalmente se entende por oppida as concentrações urbanas construídas em lugares altos e dotadas de defesa, ou seja, os grandes castros do Noroeste. Nos textos de Plínio aparecem como uma sedes civitatis urbe, referindo-se esse termo a qualquer tipo de assentamento urbano, deixando de lado os tipos diferentes, tamanhos ou defesas do assentamento. Sobre esse tema conferir em: A. Capalvo (1986: 55); Silva (1986); A. Ruiz; M. Molinos (1993: 127); F. Lemos, (2009a); G. Cruz (2014: 407-428); J. Fonte (2015: 54-68).
} 
(Ampúrias), com o objetivo de cortar a retaguarda de abastecimento aos cartagineses que estavam em marcha em direção à Península Itálica. Segundo Álvarez (1999: 223):

El comienzo de la conquista en el año 218 a.C. se plantea con el fin de eliminar el poder cartaginés en Hispania. Se enmarca, por tanto, en la Segúnda Guerra Púnica [...]. En la propaganda política, Roma aparece como la libertadora de los hispanos. La realidad será diferente: Roma permanece en Hispania como conquistadora y explotadora de los recursos económicos. El planteamiento de Roma es, pues, clara y abiertamente imperialista. Eliminar el dominio cartaginés es el paso previo para conquistar los territorios peninsulares.

Durante a segunda metade do século III a.C., os movimentos romanos na Península Ibérica foram direcionados contra os cartagineses. Somente com a vitória romana nesse conflito é que se inicia uma nova etapa de relacionamento com os habitantes nativos.

As lutas pelo poder entre as elites senatoriais, durante o período republicano, estimulam o desenvolvimento de políticas agressivas nas províncias de modo a atender a ânsia dessa aristocracia romana por glórias militares, prestígio social e riqueza material (HARRIS, 1979: 9-41; SIDEBOTTOM, 2005: 320-321; COSTAGARCÍA, 2015: 95-111). Apesar de nem sempre se concretizar em ações bélicas, nesse cenário o emprego da violência era um recurso válido, socialmente aceitável e legalmente justificado (LÓPEZ-BARJA DE QUIROGA, 2011).

Brunt (2004: 172) observa que os governantes das províncias atuavam como agentes privados cuja liberdade de ação estava limitada pela legalidade estabelecida pelo conjunto de seus pares, que também eram seus competidores naturais.

As terras da Hispânia eram muito ricas, mas estavam afastadas entre si e ameaçadas pelos Celtiberos ${ }^{38}$ (Meseta Norte) e pelos Lusitanos (Meseta Sul). Para administrá-las de maneira mais eficaz, em 197 a.C. Roma as dividiu em duas províncias: Hispânia Ulterior, a mais afastada (Ocidente da Península), e Hispânia Citerior, a mais próxima de Roma (Oriente) (Figura 2.a). A fronteira situava-se nas proximidades de Nova Carthago.

\footnotetext{
$38 \mathrm{O}$ vocábulo celtiberos é um termo exoétnico, provavelmente de origem grega ou púnica, que surgiu nas fontes textuais antigas para se referir a população composta pela mistura étnica entre celtas e iberos (DIODORO, Hist. Univ., 5; APIANO Iberia 2; ESTRABÃO III, 4, 5). São vocábulos formados pela soma de dois grupos étnicos já conhecidos e/ou pelo etnônimo e topônimo correspondente a um território distinto de onde se considerava originário o primeiro grupo. Para uma visão geral sobre o assunto consultar: Lorrio (1997); Burillo Mozota (1998; 2009); García Quintela (2012). Sobre a problemática das primeiras informações de celtiberos nas fontes antigas e as menções mais concretas do século II a.C. ver: Capalvo Liesa, 1996: 23-4; Pelegrín Campo, 2005; Beltrán Lloris, 2004: 109.
} 


\section{Figura 2.a}

Províncias da Hispânia antes de 27 a. C.

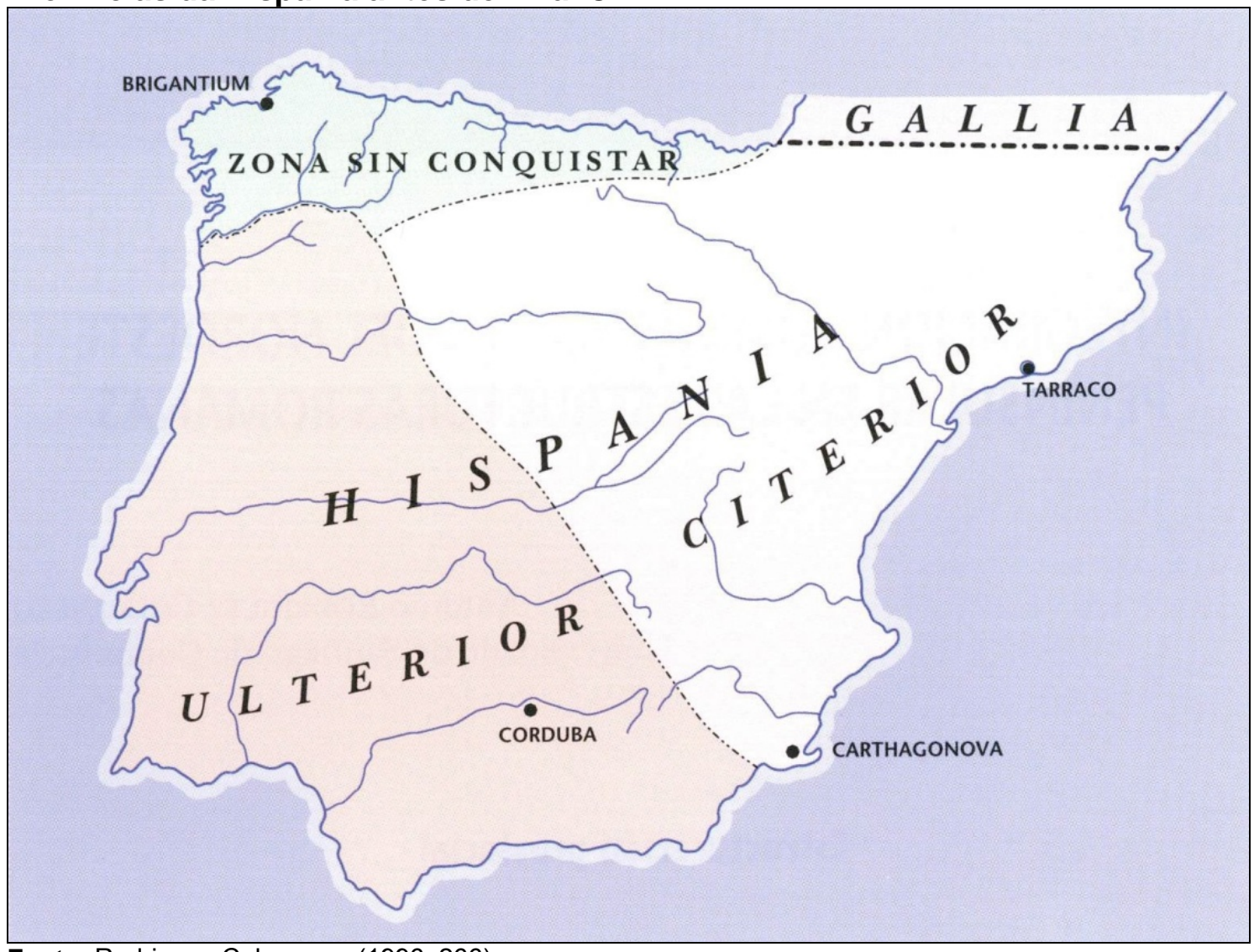

Fonte: Rodriguez Colmenero (1996: 266).

Segundo Richardson (1986: 4):

Throughout this time the formal procedures which set up the commands in Spain remained virtually unaltered: year by year the main, and often the only, business of the senate in Rome connected with the area was the naming of the Provinciae of Hispania Citerior and Hispania Ulterior to be allotted, usually to praetors, for the exercise of consular 'imperium', or the extension of the commands of such governors already present there.

Para governá-las, foram destinados dois magistrados com imperium, na qualidade de pretores, Caio Semprônio Tuditano (Citerior) e Marco Hélvio (Ulterior), com a incumbência de pacificar suas respectivas regiões para uma exploração territorial. De acordo com Richardson (1986: 55), a estrutura de comando na Espanha estava definida em dois níveis:

In constitutional terms, the determination of areas of responsibility ('provinciae') and of power ('imperium') was decided by the senate and people of Rome, in various combinations; in practice, questions as to who should command which troops, and where and how they should fight were decided on the spot. 
Dentre os magistrados, os que mais se destacaram em campanhas militares contra as rebeliões nas províncias da Hispânia foram: Marco Pórcio Catão (195 a.C.) que promoveu campanhas na Citerior e conquistou a honra do Triunfo; Tibério Semprônio Graco (180 e 179 a.C.) - considerado o grande pacificador da Hispânia e limitador de suas fronteiras; e Décimo Júnio Bruto (138-136 a.C) - que promoveu campanhas na Gallaecia e também conquistou a honra do Triunfo.

Entre 182 e 179 a.C., as campanhas conduzidas pelos pretores Quinto Fúlvio Flaco e Tibério Semprônio Graco tiveram como objetivo atacar diretamente a região da Celtibéria $^{39}$. Essas campanhas ficaram conhecidas como Primeira Guerra Celtibérica ${ }^{40}$.

Apesar da dificuldade em localizar com certeza alguns dos enclaves mencionados sobre tais campanhas nas fontes escritas, parece claro que esses magistrados lançaram mão de uma ofensiva em "forma de pinça", com ataques sucessivos desde a Carpetânia e o Vale do Ebro - as duas rotas pelas quais poderia se atingir o coração da Celtibéria (GARCÍA RIAZA, 2006: 86-7) (Figura 2.b).

\section{Figura 2.b}

Campanhas de Quinto Fúlvio Flaco e Tibério Semprônio Graco: 182-179 a.C.

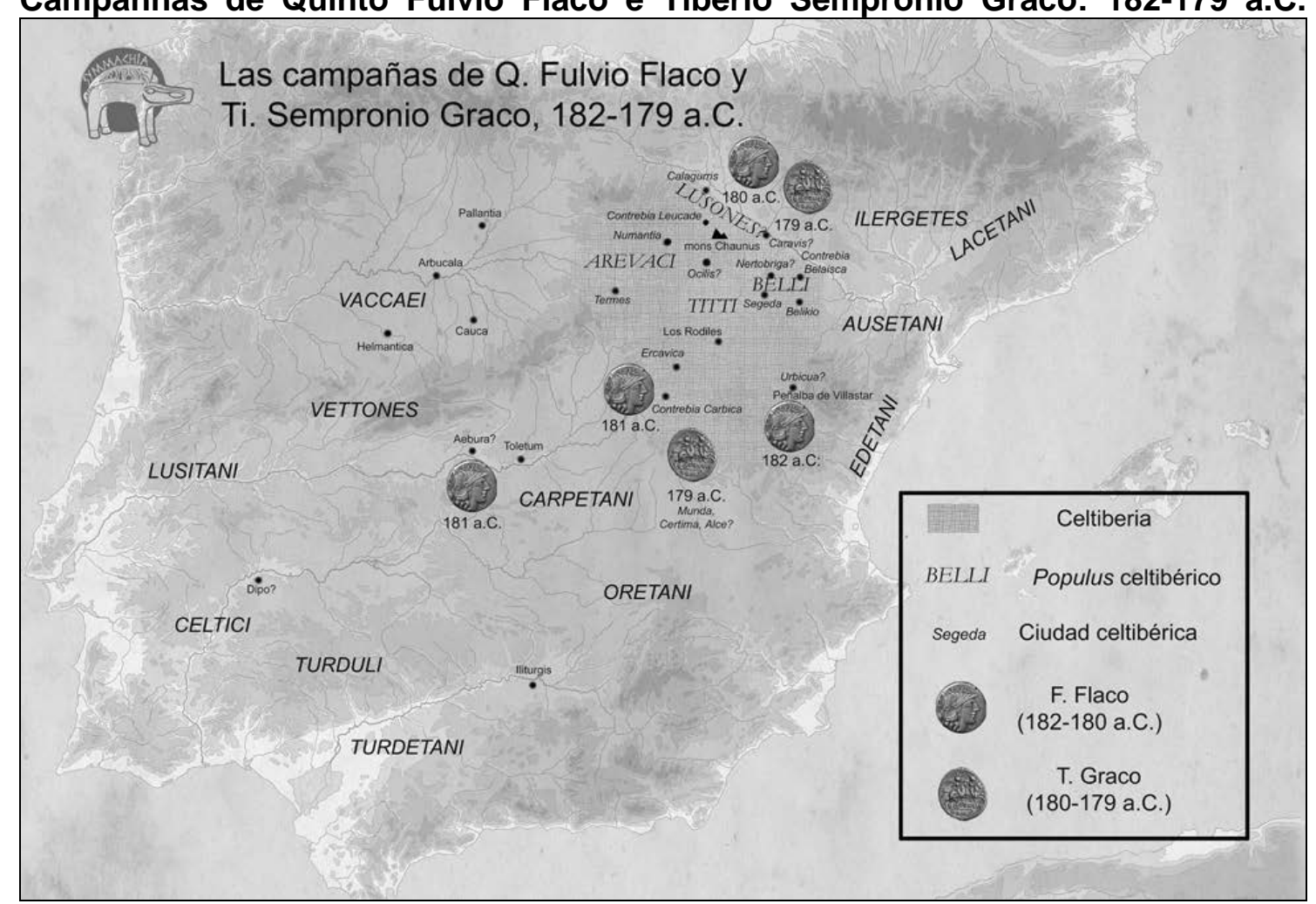

Fonte: Pérez Rubio et al. (2013: 695).

Essa estratégia utilizada é bastante interessante já que demonstra que Roma estava adquirindo um conhecimento crescente sobre a geografia da Península Ibérica e se esforçava em realizar uma expansão coordenada de suas fronteiras, tanto da Citerior quanto da Ulterior.

A atuação de Tibério Semprônio Graco foi finalizada com a pacificação da Celtibéria, certificada através de uma série de tratados que se mantiveram vigentes

${ }^{39}$ Celtibéria deriva do vocábulo celtiberos. Ver nota 37.

40 Para uma interpretação geral das campanhas romanas contra os celtiberos ver: GARCíA RIAZA (2002). 
durante as décadas seguintes (GARCÍA RIAZA, 2006: 90-92). Provavelmente, tratouse de um acordo com cláusulas comuns para cada comunidade referendaria, como se pode deduzir a partir dos acontecimentos que desencadearam a Segunda Guerra Celtibérica, em 154 a.C. ${ }^{41}$ Segundo Jimeno et al. (1990: 36):

La llegada de Roma a la Celtiberia coincidió con la descomposición que se estaba produciendo en su organización tribal o gentilicia, ya que algunos bienes habian dejado de ser colectivos y habian pasado a ser de propiedad privada, como el ganado. [...] Todo ello debió producir enfrentamientos internos $y$ entre grupos, $y$ progresivamente entre ganaderos y agricultores que limitaban el pasto para el ganado, que debieron ser espoleados e incentivados por la llegada de los romanos.

Sólo Graco, así como posteriormente Marcelo, entendió la situación económica y social por la que atravesaban los celtíberos $y$, después de vencerlos en 186 a.C. al pie del Moncayo, trató de conseguir una paz duradera incluyendo entre las condiciones, atendiendo peticiones celtibéricas, repartos de tierra, además del pago de un tributo, obligación de prestar servicio militar, no edificar ciudades nuevas ni fortificar las viejas, $y$ se les otorgaba a las ciudades el derecho a acuñar moneda.

El espíritu y condiciones de este tratado, si no consiguieron una pacificación total - en un momento dominado por la conquista y explotación económica de Roma -, sí dieron una cierta paz y tranquilidad en las tierras controladas por Roma en los treinta y tres años siguientes.

O longo processo de conquista da Hispânia teve baixa repercussão na literatura da época, com exceção de algumas referências a campanhas militares ou narrativas relacionadas a guerras que levaram a submissão de algum núcleo urbano. Provavelmente, "o silêncio da literatura antiga poderá explicar-se pela escassa atenção que se concedia aos episódios bélicos contra exércitos tribais, "guerras menores' do ponto de vista romano" (FABIÃO, 2012: 26).

Especificamente, é pouco o que as fontes textuais nos informam sobre a conquista do Ocidente Peninsular. A partir de 154 a.C. as fontes escritas proporcionam uma imagem mais clara tanto da área geográfica como das comunidades implicadas na defesa das fronteiras da Celtibéria. Entretanto, Pina (2006: 78-80) chama a atenção para o avanço equivocado dos romanos, já que se pensava numa expansão do sul ao norte de suas fronteiras - mas, na prática, assumia uma orientação sul-norte para os Pirineus em lugar de leste-oeste (Figura 2.c).

\footnotetext{
41 O casus belli para a Segunda Guerra Celtibérica teria sido a ampliação da muralha de Segeda, oppidum dos belos, como parte de um processo de sinecismo que procurava a integração nessa população de comunidades vizinhas, entre as quais estaria a vizinha população dos Titos (Apiano, Iberia, 44; Burillo Mozota, 2003: 193-215). Segundo Burillo Mozota (2001-2002: 415-430; 2006: 193-215), as escavações realizadas no Poyo de Mara confirmam a informação de Apiano.
} 
Figura 2.c

Expansão da conquista romana na Península Ibérica, por volta de 154 a.C., de acordo com a Geografia de Estrabão

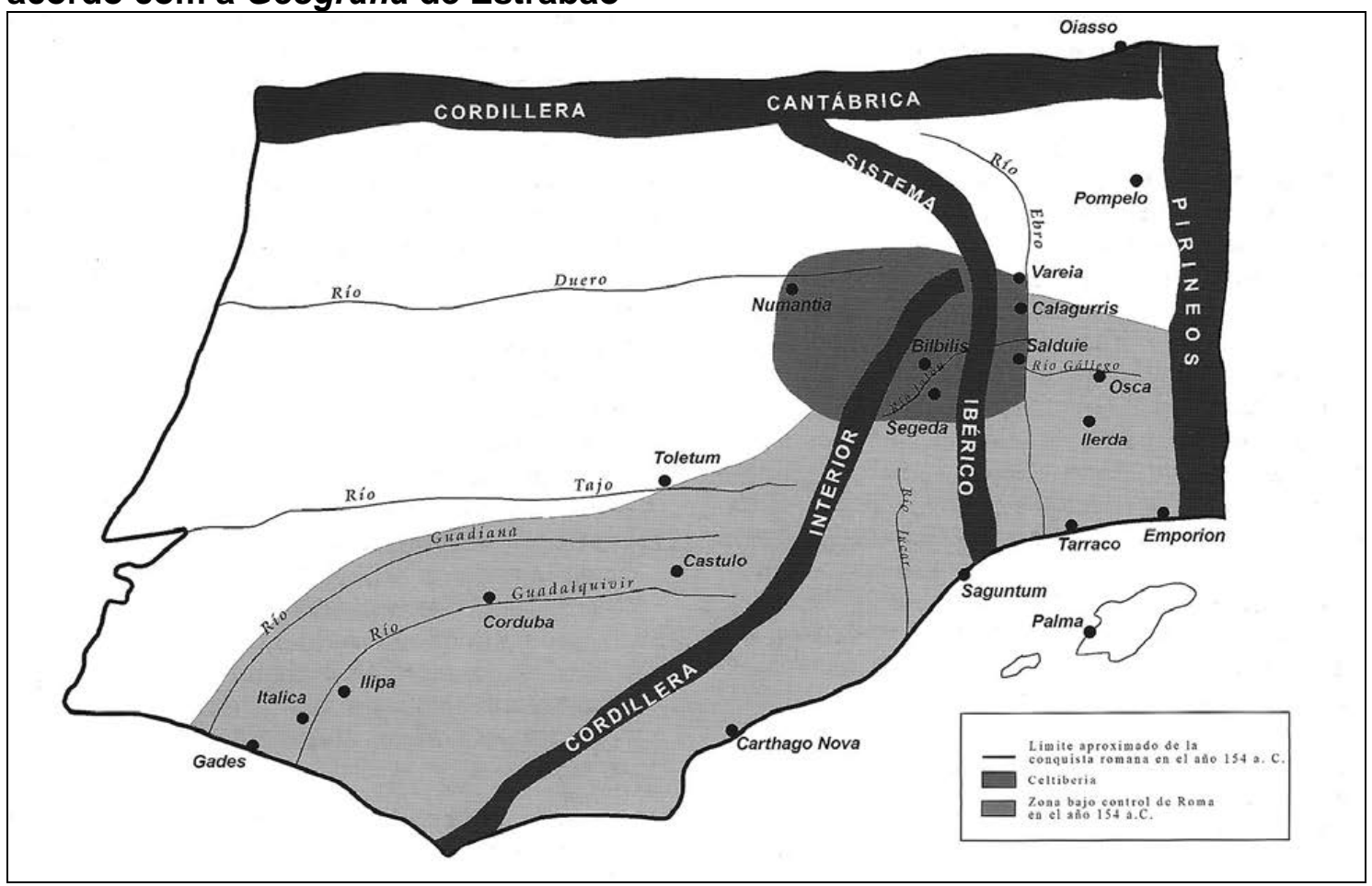

Fonte: Pina (2006: 79).

Apesar da iniciativa de Roma em estruturar um quadro administrativo na região, a "Hispânia era, ainda e apenas, um pedaço de território, ligado à capital pelos exércitos, pela descoberta e exploração das riquezas, um verdadeiro mosaico de disparidades culturais e étnicas, e um palco privilegiado das guerras civis romanas" (CARVALHO, 2008: 82).

Entre 155-133 a.C., as ações militares no interior do território celtibérico continuam. O episódio mais emblemático dessas ações é o cerco e a conquista de Numância, que encerra esse ciclo das Guerras Celtibéricas (BURILLO MOZOTA, 1998: 245-251). Outrossim, as fontes textuais informam que as Guerras Lusitanas fornecem o motivo para as primeiras iniciativas expedicionárias romanas às terras ao norte do Douro. Portanto, durante a segunda metade do século II a.C., os romanos atuam em duas frentes simultâneas.

A campanha militar de Quinto Servílio Cipião, em 139 a.C, contra Viriato, chefe militar lusitano, e os povos que se agrupam a ele, representa o primeiro confronto entre romanos e galaicos (Callaeci $)^{42}$. Segundo Apiano (Iberia, 66-68, 70), Cipião atacou lusitanos, vetões e galaicos, sendo que estes estavam situados ao norte do Douro (Figura 2.d), aparentemente junto ao Atlântico (TRANOY, 1981: 65-66; ALARCÃO, 2002: 21-22).

42 Para González Ruibal (2006-2007: 443-444) os primeiros enfrentamentos entre romanos e galaicos se deram antes das Guerras Lusitanas; provavelmente remontando à Segunda Guerra Púnica na qual os galaicos participaram em favor dos púnicos devido as relações próximas que existiam em decorrência de contatos comerciais. 


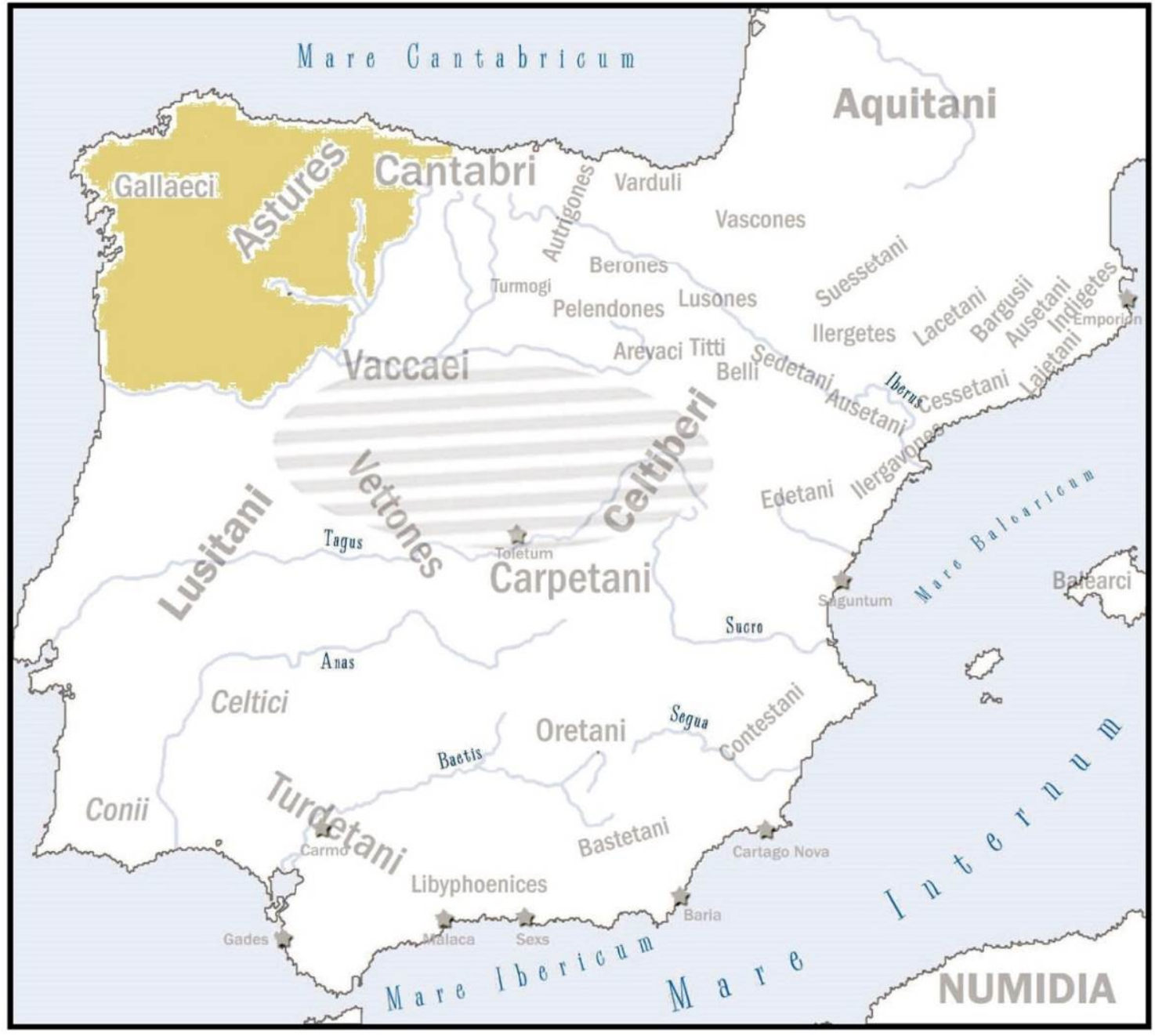

Fonte: Adaptado de Pérez Rubio et al. (2013: 65).

De acordo com Tranoy (1981: 126), em 139 a.C., depois de Cipião conseguir que Viriato recuasse, sua estratégia consistiu em agir em duas frentes, ao sul e ao norte. A ação pela frente norte teve como consequência um avanço pelos territórios vetão e galaico, embora essa incursão acima do Douro deva ter sido mais de reconhecimento do que um objetivo militar. Para Alonso $(1996,56)$, é possível que tenha sido simplesmente uma expedição de castigo para consolidar o domínio mais meridional.

Essas campanhas (139-138 a.C.) inauguram à "fase lusitana" da conquista da Gallaecia $^{43}$ (ARIAS VILAS, 1992: 17). No entanto, serão necessárias três investidas por parte de Roma para conquistar totalmente a região da Gallaecia: a campanha militar de Décimo Júnio Bruto (138-136 a.C.); a expedição de Júlio César (61-60 a.C.); e como parte da estratégia das Guerras Cântabras (29-10 a.C.).

${ }^{43}$ A denominação Gallaecia estendeu-se (por parte dos romanos) ao conjunto do Noroeste da Península, e durante mais de duzentos anos designou a região ocupada pelos Conventos Jurídicos de Lucus Augusti e de Bracara Augusta, pertencendo o de Asturica Augusta à Asturia, mencionada pelas fontes (ARIAS VILAS, 1992: 14). 
Diversos autores greco-latinos se referem aos relatos históricos da conquista do Noroeste Peninsular. Informações provenientes de escritores greco-romanos, como, por exemplo, Políbio, Estrabão, Tito Lívio, Apiano e Plínio, têm sido uma fonte de informação importante sobre Roma e suas províncias, apesar de a maioria o fazer apenas de passagem e de forma exagerada.

Essas informações devem ser filtradas e analisadas como discursos construídos que visam justificar a conquista romana através de uma imagem estereotipada dos povos nativos (SALINAS DE FRÍAS, 1998; GONZÁLEZ BALLESTEROS, 2009). Apesar disso, essas informações nos permitem conhecer povos e localidades que até aquele momento se ignorava quase por inteiro. Assim, a proposta de Filippo Coarelli (1983: 301) parece ser a mais adequada ao sugerir a superação das posições hiper e hipo críticas, ainda vigentes, quando se relacionam fontes textuais e fontes arqueológicas ${ }^{44}$.

As primeiras informações sobre os povos do Noroeste estão ligadas às riquezas naturais da região e ao caráter forte de seus guerreiros. De acordo com Arias Vilas (1992: 17), "de aí que xa no s. Il a.C. estean documentados contactos comerciais por parte romana na banda costeira, e que a zona dos galaicos se cite durante as guerras de Roma con lusitanos de Viriato".

A paz firmada entre Quinto Servílio Cipião e os lusitanos, em 139 a.C, não foi duradoura e já no ano seguinte foi preciso enviar contra eles uma expedição liderada pelo pró-cônsul Décimo Júnio Bruto. Dessa forma, será Décimo Júnio Bruto, governador da Hispânia Ulterior, quem irá liderar, entre 138/136 a.C, a primeira expedição para o Noroeste Peninsular. Segundo informações de Apiano (Iberia, 73-75, 135), "Bruto, com um exército considerável, se movimentava atacando suas cidades, renunciando, contudo, a perseguí-los pela totalidade daquela vasta região compreendida entre os rios Baetis (atual Guadalquivir) e Lima (ou Lethes) ${ }^{45}$, pátria de lusitanos e galaicos".

Reunindo alguns dados fornecidos pelas fontes textuais ${ }^{46}$, podemos sintetizar os relatos históricos da campanha militar de Bruto dessa maneira:

Os romanos partiram de Morón, nas margens do Tejo, tendo previamente fortificado Olisipo (Lisboa) como uma base de apoio.

Bruto opta por não fazer frente a alguns nativos que empregavam táticas de guerrilha. Assim, decide por atacar seus núcleos habitacionais para forçá-los a se dispersar, pois quando estes tivessem a informação de ameaça a seus povoados tentariam retornar de modo a protegê-los.

Nesses combates, os romanos não enfrentam somente homens, mas também mulheres armadas que, em muitos casos, matam seus filhos e se suicidam antes de serem capturadas.

Tendo pacificado a Lusitânia, Bruto avança em direção ao Minho. Ao longo do caminho, chega às margens do "rio do esquecimento", flumen Oblivionem, identificado com o Lethes da mitologia grega. Seus homens, com medo, se recusam a atravessá-lo pelo fato de acreditarem que todos aqueles que entrassem

\footnotetext{
${ }^{44}$ Contudo, é interessante destacarmos que as fontes textuais e as fontes arqueológicas correspondem a 'dois sistemas documentais de natureza diversa e, portanto, de aproveitamento diverso. Podem ser produtivos um ao outro, mas é problemático [...] tentar cruzá-los automaticamente' (SILVA, 2003: 40).

45 O Lethes é identificado tanto com o Lima (TIR-K29: Porto), como com o Leça (Guerra, 1996).

46 Os seguintes autores nos dão informações sobre a campanha de Bruto: Estrabão (Geographia, III, 3,1 e III, 3, 4), Apiano (Iberia, 71-72), Tito Lívio (Ab Urbe Condita, Periochae, 55 e 56), Orósio (Historiae Adversus Paganos, V, 5, 12), Ovídio (Fasti, VI, 461-462).
} 
naquelas águas se esqueceriam quem eram e de onde vinham. Nesse momento, Bruto cruza esse rio carregando o estandarte da legião. Chegando na outra margem, crava o estandarte no solo e chama os soldados pelo nome para que estes comprovassem que ele não havia perdido sua memória. Desse modo os persuade a atravessá-lo.

Ao alcançar a costa atlântica, um pôr do sol sobre o oceano aterroriza os romanos, o que denota um claro significado simbólico de finis terrae. Bruto vê este evento como um sacrilégio e decide recuar. Em seu retorno, quando a legião chega ao Douro, acontece uma grande batalha contra os brácaros. Em razão dessa sequência de êxitos, Décimo Júnio Bruto recebe o apelido de "Galaico".

A partir da síntese acima, podemos estabelecer algumas linhas interpretativas para tentar compreender o cenário da conquista do Noroeste Peninsular.

Primeiramente, em relação à vitória de Bruto sobre os Galaicos, os Fastos Capitolinos (Fasti Capitolini Consulares et Triumphales) confirmam a celebração de seu Triunfo como pró-cônsul de Lusitanos e Galaicos no ano 617 da Fundação de Roma. Para José Ignacio San Vicente (2014: 50),

[...] el triunfo fue real, ya que el Senado le otorgó el título de Callaicus, por lo que si se sitúa la victoria de Décimo Junio Bruto sobre los galaicos el 9 de junio del año 136 y es anterior a la derrota que sufrió junto con Lépido ante Pallantia, el sitio de la ciudad vaccea debió ser posterior a esa fecha.

Sobre a retirada antecipada de Décimo Bruto Júnio do território galaico para o outro lado do rio Douro, essa aconteceu pela necessidade real de dar apoio a Lépido, que tinha atacado Numância sem o prévio consentimento do Senado. Além disso, os Brácaros, localizados ao norte do Douro, revoltaram-se e Bruto também teve que sufocar esse levante. Segundo San Vicente (2014: 51):

\begin{abstract}
El triunfo de Bruto del 9 de junio del 136 sobre los galaicos pudo acelerar su decisión de emprender el sitio de Pallantia por lo que pediría ayuda y consejo a Décimo Junio Bruto, que era el gobernador de la Ulterior, pero cuya área de actuación venía siendo la Lusitania, zona cercana al teatro de operaciones de la Meseta.
\end{abstract}

Pouco se sabe, até o momento, sobre a conquista romana do Noroeste Peninsular e do que, posteriormente, veio a ser conhecida como Gallaecia. A maior parte dos vestígios materiais, como, por exemplo, habitações, calçadas, muralhas e outras obras de infra-estruturas, correspondem ao período de povoamento.

Entretanto, determinados pesquisadores relacionam algumas evidências no registro arqueológico com a campanha de Bruto. Seria o caso de níveis de destruição em grandes castros, como a Citânia de Briteiros, Sanfins, Santa Luzia e Cividade de Terroso; o abandono da parte alta do Coto da Pena, ou a ocultação de alguns tesouros, como o de Laundos, o de Estela, o de Afife e o de Carreço (SILVA, 1986: 3743; HAWKES, 1958: 446-453). Para Tranoy (1981: 128), essa campanha deixou marcas visíveis em alguns castros próximos à costa como, por exemplo, no Castro de Sabroso. Rodríguez Colmenero (1977: 39) comenta que os achados de tesouros, constituídos exclusivamente por moedas do período Republicano, séculos II e I a.C., 
na área ocidental do Entre Douro e Minho, demonstram a "precoce influência 'romanizadora' nessa região".

Consta, nas informações das fontes textuais, que Bruto utilizou como base de operações a linha fluvial do Tejo, que foi de grande valia tanto para a conquista do litoral como a do interior. A informação de Estrabão é interessante pois, além de situar o ocorrido logo após o final da Guerra Lusitana, também identifica as cidades de Olisipo (atual Lisboa) e Morón. Rodríguez Colmenero (1977: 33), com base nas informações de Estrabão (III, 3, 1), diz que:

[...] un estratégico islote de las cercanías de Morón, situado a unos quinientos estadios (100 km), río arriba de Olisipo, fue convertido en base general de aprovisionamiento. A Olisipo misma, en la boca del río, se la fortificó como punto de protección para las naves cargadas con vituallas para la guerra.

Para Alarcão (2002: 22), indo ao encontro à proposição de Sousa Soares (1962: 34), a exata localização de Morón é ainda incerta, "mas é forçoso procurá-la na área de Santarém ou Alpiarça". Carlos Fabião (2012: 27) indica que, talvez, Morón possa ser identificada com o sítio arqueológico de Chões de Alpompé, próximo a Santarém, "como as bases de retaguarda da operação". E complementa: "Se assim foi, o Sudoeste da Península já estaria então sob domínio romano".

Contudo, para Rodríguez Colmenero (1977: 33 apud SCHULTEN, 1937: 138), Morón, provavelmente identificada com o Almourol atual, estaria situada próxima à confluência dos rios Zêzere e Tejo, em um ponto estratégico, "muito apto para penetrar ao longo da dorsal norte-sul da Lusitânia".

Tranoy (1981: 127), baseando-se em uma passagem de Festo (Breviarium, 5, 1), argumenta que a travessia em direção ao território galaico teria sido realizada junto à Foz do Douro pois entende que Festo faz referência à Cale e não a Gades, que justifica como erro de escrita. Seu avanço em direção ao norte do Douro teria atingido o Vale do Minho após o episódio da travessia do Lima (Lethes), que as fontes textuais enfatizam ${ }^{47}$.

Rodríguez Colmenero (1977: 33-36) argumenta que Bruto evitou sistematicamente as serras e locais pouco acessíveis e seguiu pela bacia do Zêzere, orientada para NE, para iniciar seu avanço em direção à região setentrional. Porque "si su intención hubiese sido castigar solamente la franja litoral, en modo alguno hubiese elegido esta posición mediterránea". Esse autor não exclui a possibilidade de que a estratégia de Bruto tenha também se apoiado nas possíveis legiões que subiriam ao longo da costa, mantendo contatos com o exército do interior através das bacias dos rios, como, por exemplo, o Mondego. Entretanto, apesar de não excluir a possibilidade de "operaciones rutinarias de apoyo a las tropas del famoso cónsul por parte de la marina comercial de las ciudades tributarias del litoral atlántico meridional de la península"; o autor enfatiza que o avanço da expedição de Bruto "hubo de ser interior, al menos una vez rebasado el Duero, si queremos hacer honor a su condición de vencedor de los Galaicos ya que, entre este pueblo y el litoral, se interpone, al menos, el territorio de los Brácaros" (RODRÍGUES COLMENERO 1995b: 92).

${ }^{47}$ Principalmente em Tito Lívio (Ab Urbe Condita, Periochae, 55) e Floro (Iberia, 33, 12). 
Assim, essas duas formações militares coincidiriam em algum ponto às margens do Douro após terem ultrapassado as serras da Estrela e de Montemuro. A partir da análise das informações de Apiano (Iberia, 73-75) e Floro (1, 33, 12), Rodríguez Colmenero conclui que Bruto percorreu o caminho de ida até o Minho pelas áreas interioranas da Lusitânia e da Galícia; e regressou pelo caminho ao longo da costa até a foz do Douro.

Para o autor, a etnia dos galaicos, no momento da conquista, estava assim localizada: em uma zona intermediária entre o Douro e o Minho de um lado; e as Serras do Gerês e de Queixa, além dos celtiberos de outro lado. Se, de fato, a localização dos galaicos era essa, Bruto necessitou penetrar nessas áreas interioranas para combatê-los. "Su expedición, por tanto, no ha sido costera y litoral, [...] sino más bien INTERIOR a la ida y LITORAL al regreso, como exige la lógica de los acontecimientos." (RODRÍGUEZ COLMENERO, 1977: 36).

Estamos de acordo com a lógica dessa mobilidade se forem consideradas as rotas naturais de comunicação que se articulam hierarquicamente e que permitem traçar uma rota principal. Isso se justifica pelo fato de tomarmos como proposição que o meio ambiente e o quadro geográfico são importantes no condicionamento do comportamento das comunidades e, consequentemente, em suas estratégias de povoamento. Portanto, no nosso ponto de vista, um caminho lógico de penetração no território galaico que, provavelmente, deve ter sido utilizado pelas legiões romanas, é o corredor natural formado ao longo da Depressão Meridiana.

Diferentemente dos rios, as depressões favorecem a comunicação. Dessa forma, as depressões são utilizadas como áreas de passagem desde períodos préhistóricos até a atualidade (FERREIRA 1987; NÁRDIZ 1992; GONZÁLEZ RUIBAL, 2006). Por essas depressões foram percorridas as principais vias romanas do Noroeste. Como pode ser observado na Figura 2.e, as depressões do Noroeste são: 1. Pontes e Meirama; 2. Terra Chá; 3. Sarria - Monforte - Quiroga; 4. Depressão Meridiana; 5. Limia e Verín.

A Depressão Meridiana é formada por uma linha de fraturas que cruza quase toda a Galícia atual de norte a sul, desde o norte de Carballo até Tui e o norte de Portugal. Encaixa-se nas bocas das Rias Baixas como seu limite oriental, já que os rios atlânticos aproveitam esse espaço para continuar a formação dos seus vales por alí. Las principales vías de penetración hacia el montañoso interior han sido fundamentalmente los valles de los grandes ríos, junto a determinadas depresiones (GONZÁLEZ RUIBAL, 2006: 63).

Dessa forma, existem nós viários onde essas fraturas se cruzam: no sentido Norte-Sul da Depressão Meridiana e no sentido Nordeste-Sudoeste da rede fluvial e das Rias Baixas. Portanto, a Depressão Meridiana é uma "rota inevitável de penetração na Galícia a partir do sul” (GONZÁLEZ RUIBAL, 2001: 157).

Segundo Torres Luna (1990: 37):

A Depresión Meridiana é un corredor fundido de dobre orixe, á vez topográfica e tectónica que percorre Galicia de Norte a Sur, ó longo duns $150 \mathrm{~km}$, e que conecta de modo natural, dende Tui a Carballo, toda a franxa maritima occidental de Galicia. 


\section{Figura 2.e}

\section{Relevo da Galícia: Depressão Meridiana (4)}

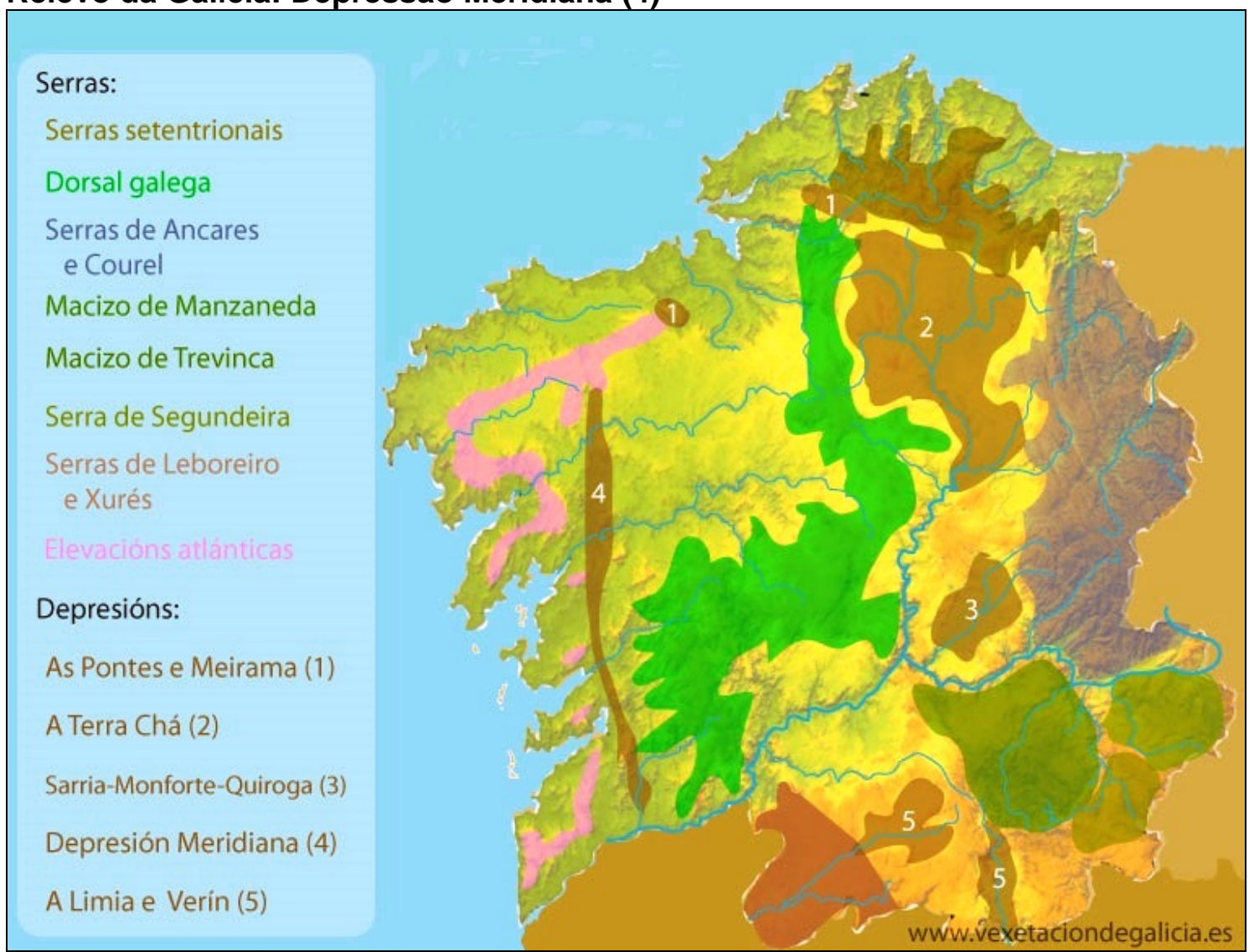

Fonte: MOURAZOS GONZÁLEZ, M.J. Mini-Atlas Xeobotánico de Galicia. Xunta de Galicia, Consellería de Educación e Ordenación Universitaria, 2010.

Essas rotas naturais teriam facilitado o deslocamento das legiões romanas em direção ao interior da região da Gallaecia, área bem definida por barreiras físicas. Além do fato de que esse corredor natural formado ao longo da Depressão Meridiana tem, possivelmente, sua utilização como via de comunicação entre as áreas que correspondem ao norte de Portugal e Galícia atuais desde o Bronze Final. Isso pode ser atestado pelos diversos vestígios associados a essa via de comunicação natural como, por exemplo, castros, mamoas, petróglifos e depósitos de bronze.

A alta densidade dos megalitos (dólmens ou antas, podendo ser recobertos por um tumulus ou Mamoa ${ }^{48}$ ) no litoral ocidental da Península e no Noroeste revela um povoamento importante dessas regiões desde a época neolítica (LÓPEZ CUEVILLAS, 1973: 43-115; SAVORY, 1968: 105-107; LÓPEZ SÁEZ; LÓPEZ MERINO; PÉREZ DÍAZ, 2010: 488-496).

As análises polínicas realizadas nessas áreas demonstram um forte impacto antrópico na paisagem decorrente do desmatamento e da construção desses monumentos megalíticos a partir da primeira metade do IVo Milênico a.C. De acordo com LÓPEZ SÁEZ; LÓPEZ MERINO; PÉREZ DÍAZ (2010: 494),

${ }^{48} \mathrm{O}$ termo mamoa ou tumulus se refere a um montículo artificial, composto por terra e pedras, que cobre um monumento funerário pré-histórico (dólmem ou anta). Tem como objetivo proteger enterramentos coletivos. 
No cabe duda que fueron los mismos constructores de megalitos los que en algunos territorios gallegos concretos (llanuras de Lugo, depresiones orensanas, costas norte y sur de A Coruña, costa pontevedresa), comenzaron a deforestar el bosque en un proceso que se inició en la segunda mitad del V milenio cal. BC (ca. 4500-4000 cal. BC) antes de que los monumentos megalíticos hubieran sido erigidos, que se continuó posteriormente toda vez que se fueron levantando los megalitos al iniciarse el IV milenio cal. BC, e incluso aún más tarde en la segunda mitad del IV milenio cal. BC y probablemente en el milenio posterior. Estos hechos parecen manifestarse en todas las comarcas gallegas donde análisis polínicos y megalitos están presentes, pudiéndose establecer una relación causal entre unos $y$ otros.

$\mathrm{Na}$ região das Astúrias também encontram-se indicios de distribuição de necrópoles em estreita relação com as vías de comunicação. Segundo Marín Suárez (2009: 25), Gracias a numerosos trabajos de inventario y cartas arqueológicas sabemos que muchos de los monumentos tumulares asturianos se encuentran en collados, pasos de montaña y vías que recorren las cimas de las sierras y...

Segundo Ana Bettencourt (2009: 72), os dólmens, ou antas, encontram-se, frequentemente, agrupados em espaços relativamente restritos, formando grandes necrópoles, o que indica a sacralização desses locais, através da construção de uma memória coletiva. É interessante, nesse momento, fazermos um aparte sobre a presença das mamoas associadas a essas rotas naturais (Figura 2.f), dado que as necrópoles romanas estavam, também, frequentemente localizadas ao longo das estradas e nas saídas dos núcleos habitacionais.

Para Criado-Boado et al. (2000: 293),

Los lugares donde se construyen los túmulos constituyen ámbitos espaciales significativos; (...). En este contexto, los tumulos no constituyen sólo lugares de enterramiento (...) estas estructuras forman parte de un entramado simbólico, social y político complejo, que apunta a la reafirmación y reproducción del orden cultural a través del manejo de los muertos por parte de los vivos.

Essa organização simbólica e física nos remete ao termo Genius Loci, o "espírito do lugar". Os romanos acreditavam que existia um espírito do lugar - o Genius Loci (genius - espírito; loci - lugar). Dessa forma, cada local tinha o seu próprio genius, que se manifestava tanto no local como na configuração espacial e na caracterização de sua articulação. Para Norberg-Schulz (1980: 18):

Genius Loci is a Roman concept. According to ancient Roman belief every «independent» being has a genius, its guardian spirit. This spirit gives live to people and places, accompanies them from birth to death, and determines their character or essence. 


\section{Figura 2.f}

Relação entre as vias de trânsito naturais e a presença de mamoas

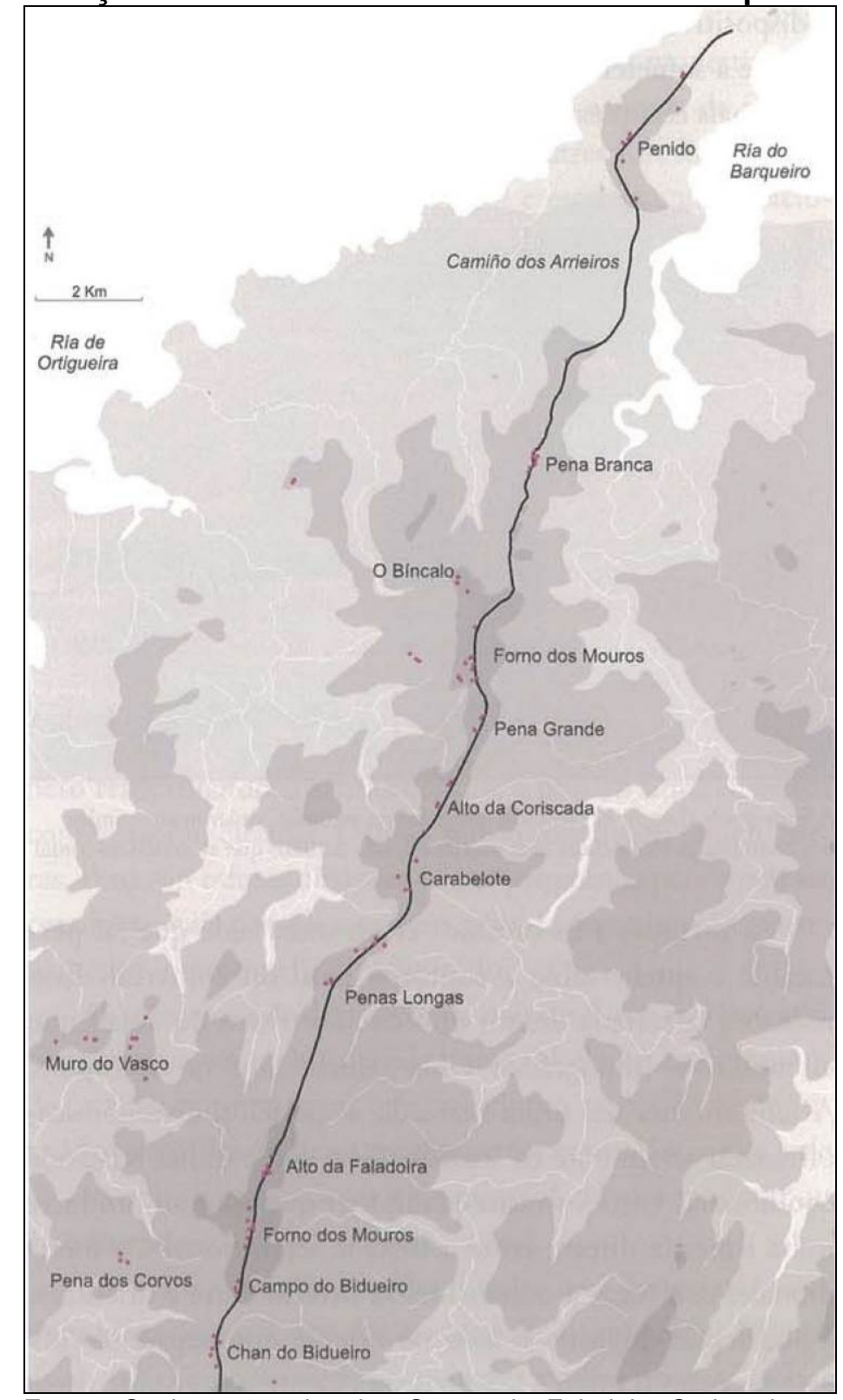

Fonte: Conjunto tumular das Serras da Faladoira-Coriscada no Camiño dos Arrieiros, Galícia (CRIADO-BOADO; MAÑANABORRAZÁS; GIANOTTI, 2016: 116).

Manuel Murguía (1888: 85 ss.), em finais do século XIX, já havia sugerido o valor territorial desses "túmulos" no contexto galego. Outros autores, como Renfrew (1975, 1976, 1983) e Fleming (1973), empreenderam uma análise mais minuciosa sobre esse tema, tendo este último os denominados de "túmulos para os vivos", considerando que estruturavam a paisagem e consolidavam as hierarquias das sociedades camponesas (FLEMING, 1973).

Segundo Ayán Vila (2012: 348), no Noroeste Peninsular, ao contrário de outras áreas, las comunidades campesinas del Neolítico Inicial y Medio generan una monumentalidad centrada en el ámbito funerario, en detrimento de la casa como entidad básica que articula la realidad social. 
Diversos monumentos megalíticos permaneceram na paisagem e, devido a isso, puderam ser objeto de novos usos e de novas reflexões, haja vista que novas sociedades e novas culturas foram, ao longo do tempo, concedendo-lhes novos significados e novas funções.

Uma das principais características das mamoas é que estão baseadas em construção de caráter monumental, que "introduz no terreno descontinuidades artificiais. Essa paisagem monumental é constituída por uma rede de relações físicas, visuais e de mobilidade que se sobrepõem ao meio" (CRIADO-BOADO; MAÑANABORRAZÁS; GIANOTTI, 2016: 114).

A localização das mamoas não é aleatória. Além de relacionar-se com os eixos de deslocamento, estabelecem jogos de intervisibilidade entre monumentos aproveitando as formas do terreno. Na Figura 2.g, podemos observar a visibilidade plural e simultânea (intervisibilidade) entre as mamoas (túmulos) ao estarem recortadas contra o horizonte.

\section{Figura 2.g}

Intervisibilidade entre as mamoas

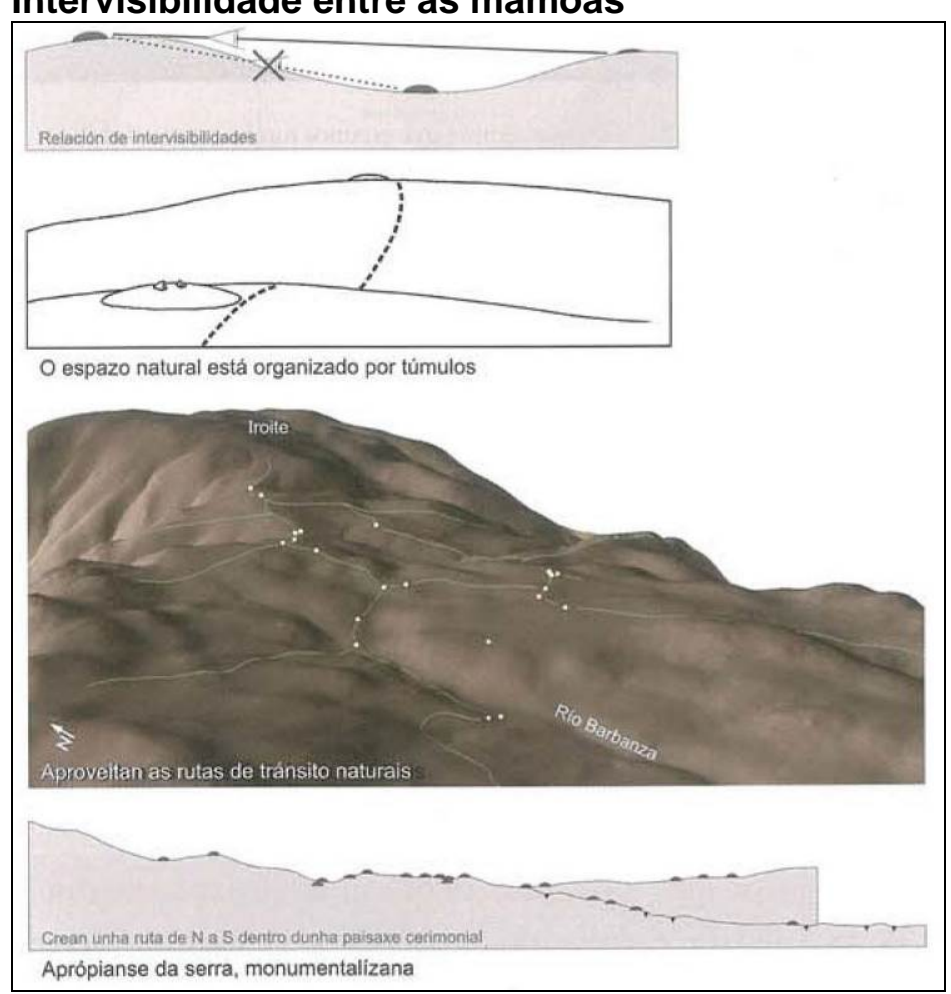

Fonte: Criado-Boado; Mañana-Borrazás; Gianotti (2016: 123).

Segundo Criado-Boado; Mañana-Borrazás; Gianotti (2016: 114-115):

As mámoas están situadas á beira e ao longo das liñas de tránsito natural que fan permeable a topografia; seguindo as relacións visuais entre mámoas pódese atopar, moitas veces, o camiño mais axeitado para atravesar unha zona ou ir dun sitio a outro. Pero o tránsito non é a razón de ser (máis concretamente a razón de estar) das mámoas; a súa función non foi marcar o camiño, aínda que tamén o marcasen. En realidade o tránsito é só o punto de partida ou, se se quere, o dispositivo elemental com base no cal se apropian da contorna e a someten a un proceso de organizaçción simbólica e física máis complexo. 
Finalizado esse aparte, podemos concluir que esse espaço (ao longo da Depressão Meridiana) foi utilizado desde tempos pré e proto-históricos (GONZÁLEZ RUIBAL, 2001) para traçar as vias de comunicação norte-sul no território da Gallaecia. Os romanos, no processo de integração do Noroeste, a utilizaram primeiramente para explorar e em seguida construir, no interior do território, uma rede viária terrestre capaz de abranger e comunicar essa realidade espacial e geográfica.

Consideramos, também, que a estratégia de avanço de Bruto tenha se apoiado na navegação de cabotagem, utilizando as vias marítimas e as vias navegáveis interiores. Dessa forma, nos aproximamos da hipótese de Casimiro Torres Rodrígues (1951-52: 79-112; 1982: 31) sobre o avanço de uma frota de apoio costeira conectada com a coluna terrestre.

Provavelmente, a campanha militar de Décimo Júnio Bruto tinha objetivo punitivo, mas não podemos descartar que também visava o reconhecimento da região, pois "[...] no es de creer que Bruto, que conquistó gloria y nombre en la dificilísima campaña [...], no hubiese procedido a la sistemática organización, al menos militar, de las tierras situadas a mediodía del Miño" (RODRÍGUEZ COLMENERO, 1977: 38).

Segundo Torres Rodrígues (1982: 25),

Sin embargo no se puede asegurar que la guerra de Décimo Junio Bruto (...) tenga exclusivamente carácter vindicativo, o de represalia; ni siquiera que este fuera su móvil principal. Tal vez se intentó con no menor intención aliviar la situación de las tropas romanas que combatían contra los vaceos de la Meseta y contra Numancia, y privarles a éstos de la ayuda de lusitanos y galaicos.

Contudo, mesmo se um dos objetivos da expedição de Bruto era amenizar a situação das tropas romanas frente aos vaceos, era imprescindível o reconhecimento da região. Assim, a forma mais adequada (e, provavelmente, a única possível) para executar o reconhecimento de um espaço geográfico tão particular como o Noroeste Peninsular, durante sua campanha, teria sido através da utilização das rotas naturais de comunicação, ou seja, no sentido Norte-Sul pela Depressão Meridiana, e pelas vias fluviais - seus cruzamentos naturais - que estabelecem a comunicação de Oeste a Leste.

De acordo com Vasco Gil Mantas (2007: 187),

“(...) não podemos esquecer que as viagens na época romana englobavam com muita frequência percursos mistos, combinando jornadas terrestres, fluviais e marítimas, sempre que possível e conveniente, o que permitia mitigar algumas das dificuldades oferecidas por um itinerário homogéneo.

Com base na distribuição de mercadorias do comércio marítimo e nas informações das fontes textuais, a Figura 2.h apresenta a localização dos trechos navegáveis e das áreas de acesso hipotéticas à navegação fluvial (NAVEIRO LÓPEZ, 1991: 269). 
Figura 2.h

Trechos navegáveis e zonas hipotéticas de penetração fluvial

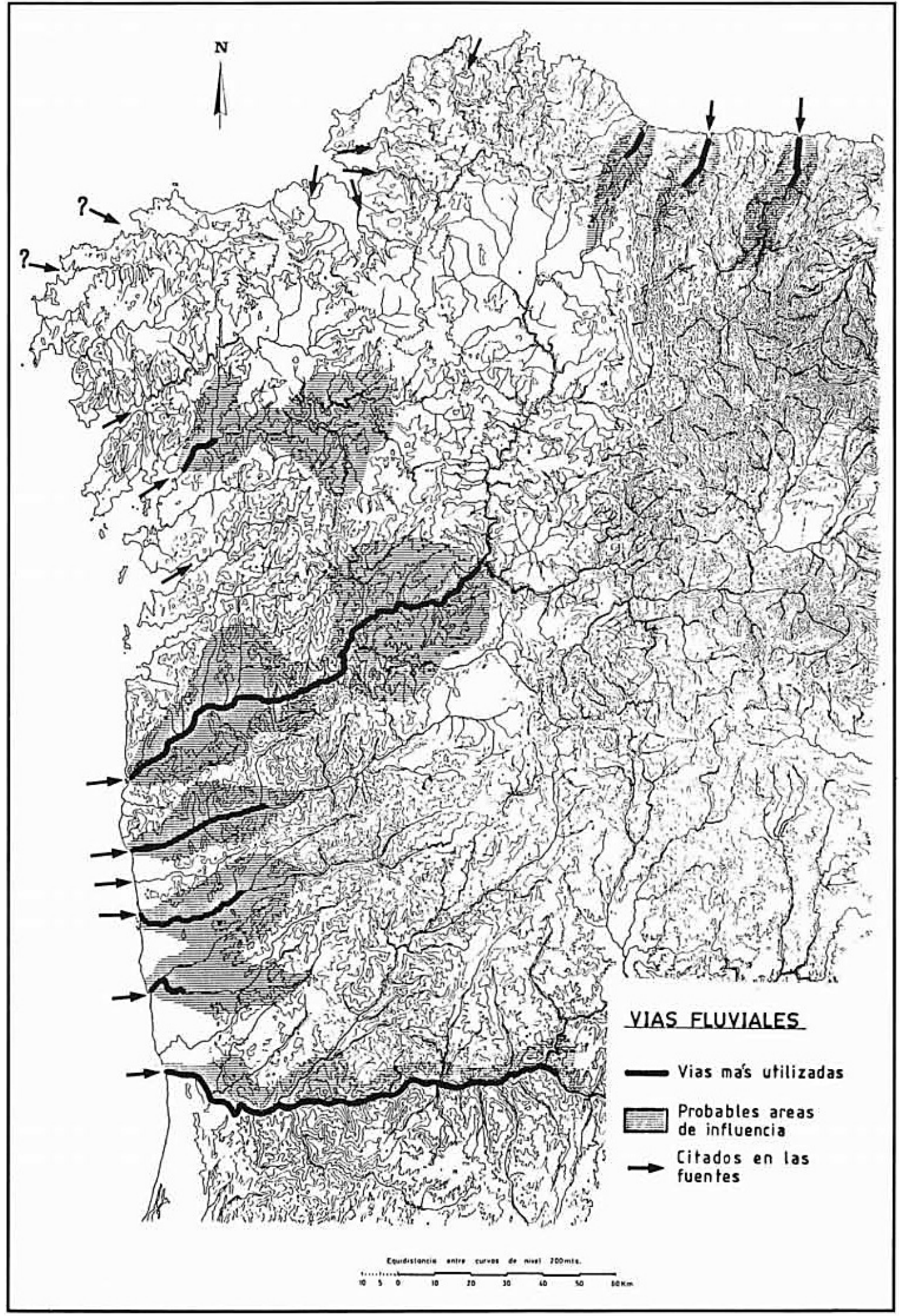

Fonte: Naveiro López (1991: 269). 
Apesar das fontes textuais serem imprecisas em vários aspectos, elas apresentam um notável conhecimento sobre a rede fluvial e destacam a navegabilidade de alguns rios. Segundo Estrabão (III, 3, 4), o Douro e o Minho seriam navegáveis em 800 estádios, e a maioria dos rios citados estariam localizados ao norte do Tejo. Apiano (Iberia, 73) insiste na navegação pelo Minho e pelo Lima; e quando se refere à travessia de Bruto pelo rio Lethes, nos informa sobre a navegabilidade de alguns rios da região:

Mas desistió de perseguirlas en aquella vasta región, comprendida entre los ríos Tajo, Lethes, Duero y Baetis, todos ellos navegables [...] así llegó hasta el río Lethes y fue el primero de los romanos que se propuso atravesarlo. (Apiano, Iberia, 73-74; grifo nosso).

Certamente a foz dos rios Minho e Douro foram pontos de apoio importantes para a navegação de pequena e grande cabotagem. $E$, provavelmente, as desembocaduras dos principais rios navegáveis do Entre-Douro-e-Minho, como o Ave, o Cávado, o Neiva e o Lima, também devem ter funcionado como importantes suportes à navegação de pequena cabotagem (CARVALHO, 2008: 117).

Provavelmente, as campanhas da conquista romana da Hispânia utilizaram esses acessos fluviais para adentrar o interior do Noroeste Peninsular, haja vista que alguns deles cruzam com o itinerário terrestre.

A nossa questão central parte da premissa de que a campanha de Bruto foi planejada e teve seu raio de ação a uma curta distância da costa, seguindo as vias de comunicação que ligavam os diferentes núcleos habitados desde o Bronze Final e que, possivelmente, foram utilizados posteriormente pelos romanos para traçar as vias de número XIX e XX (per loca maritima) do Itinerário de Antonino.

Naveiro López (1991: 21), em sua monografia sobre o comércio antigo no NO Peninsular, aponta para a difusão de material arqueológico relacionado com a configuração costeira (com maior frequência em costas recortadas, acessíveis e que oferecem abrigo), com as bacias dos rios (principalmente os navegáveis) e com as áreas de rotas naturais, cujo caso mais evidente é representado pela Depressão Meridiana.

É importante apontar, assim, a relevância da rota atlântica no âmbito do Império Romano, principalmente para desconstruir a imagem estereotipada do extremo ocidente apresentada na literatura greco-latina como "finis terrae, terra ignota, lugar de prodígios". Esta rota proporcionava bons pontos de ancoragem, devido aos amplos estuários e antigas zonas lagunares que favoreciam a navegação de cabotagem e de longo curso (FABIÃO, 2006: 130-131; 2009: 53).

Segundo Le Roux (2014: 32-34),

O oceano exterior, visto de Roma, estava revestido de uma dimensão mais simbólica que geográfica na medida em que deveria marcar o limite do mundo habitado. (...) Como em todos os lugares no Império, uma representação melhorada pelo contato direto com a realidade do terreno permitiu definir melhor e não mais recear no mesmo nível um domínio que continuava de toda maneira em grande parte desconhecido, mas era acessível à navegação costeira. 
As evidências arqueológicas apontam que a essa extrema periferia, o finis terrae atlântico, chegaram precocemente e recorrentemente artigos mediterrâneos (BALIL, 1971, 1974; FERNÁNDEZ OCHOA, 1996; NAVEIRO LÓPEZ, 1991; CUNLIFFE, 2001; GONZÁLEZ RUIBAL et al., 2007; AYÁN VILA, 2008).

Para Vasco Gil Mantas (2007: 187-188), não faltam testemunhos de contatos marítimos intensos anteriores à ocupação romana na Península Ibérica, sendo que,

(...) as relações por via marítima não se limitaram ao litoral peninsular, existindo indícios seguros de contactos para norte, e bem mais antigos, como se pode deduzir da abundante presença de materiais da Cultura Campaniforme ou, posteriormente, da ldade do Bronze, em regiões de França, Reino Unido e Irlanda, cujo mapa de distribuição permite, simultaneamente, reconhecer antiquíssimas relações atlânticas com a faixa ocidental da Península lbérica e explicar, pelo menos parcialmente, a situação na época romana, em especial a partir do final da República, sugerindo fortemente a continuidade dessas rotas e desses contactos.

A Figura 2.i abaixo, baseda em Cunliffe (2001: 227-247 apud MANTAS 2007: 188), apresenta um esboço da distribuição de vestígios materiais relativos a Idade do Bronze na Fachada Atlântica. 


\section{Figura 2.i}

Esquema de distribuição dos vestígios materiais da Idade do Bronze na Fachada Atlântica

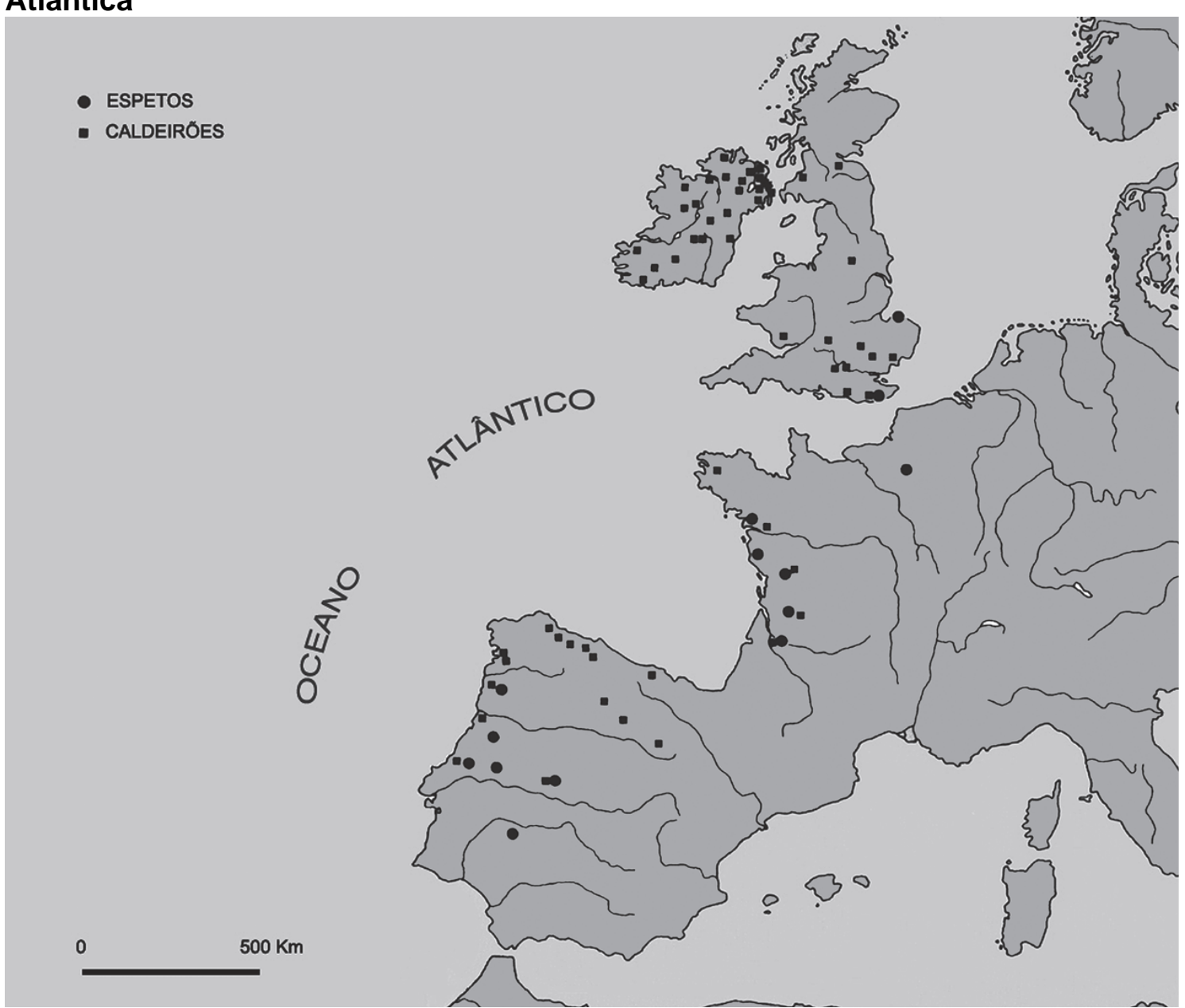

Fonte: Adaptado de CUNLIFFE 2001 (apud MANTAS 2007: 188)

Outro indício que merece ser apontado diz respeito aos faróis e outras torres de sinalização marítima e instrumento de navegação para as embarcações que em sua travessia utilizavam o corredor atlântico. Para Le Roux (2014: 34), “(...) o oceano é utilizado concretamente e os rios são delimitados e pacificados o que atestaram o farol de Brigantium (A Corunha) e os altares sestianos (arae Sestianae) de localização incerta".

Segundo Chic García (1995: 81),

El transporte de materiales y mercancías por mar, mucho más económico que el realizado por tierra, podría explicar el desarrollo de las costas portuguesas, gallegas y cantábricas, en relación con el comercio atlántico, iluminado pasado un tiempo por faros como el de Cádiz o el de La Coruña.

Assim, digno de nota é o farol de Brigantium (farol de A Coruña), a denominada "Torre de Hércules". Esse farol foi construído, provavelmente, na segunda metade do século I ou nos primeiros anos do século II d.C. pelo Império Romano no noroeste da Hispânia, na entrada do grande Golfo Ártabro, que compreende as Rias de Burgo, 
Ares e Ferrol (A Coruña, Espanha), para orientar os barcos que bordeavam o extremo mais ocidental do Império (CABALLERO ZOREDA; LATORRE GONZÁLEZ-MORO, 1998; ROMERO MASIÁ, 1997; NAVEIRO LÓPEZ, 1991, 1994; MORAIS, 2005).

Pesquisas recentes sobre a presença militar romana no Noroeste da Península Ibérica estão sendo desenvolvidas por uma equipe multidisciplinar integrada em um projeto intitulado RomanArmy.eu ${ }^{49}$. Nesses trabalhos, há uma combinação de diferentes disciplinas, como: arqueologia da paisagem, arqueologia da arquitetura, estudos documentais e tecnologias geoespaciais (imagens de satélite, fotografia aérea histórica e recente e dados LiDAR). Essas informações aplicadas aos Sistemas de Informação Geográfica (SIG), principalmente na análise de visibilidade e mobilidade, estão possibilitando enriquecer o debate sobre os motivos da concentração de acampamentos militares nessa área e quais unidades estavam envolvidas em sua construção.

As informações sobre o exército romano na Hispânia estão disponíveis, majoritariamente, nas fontes textuais. Mas como essas fontes não trazem dados sobre a distribuição das legiões romanas nas frentes e campanhas, para sua identificação e localização, recorria-se a evidências epigráficas e numismáticas, que são datadas, em sua maioria, uma década após o término das guerras cântabras (FERNANDEZ OCHOA; MORILLO CERDÁN, 1999: 37). Assim, as informações sobre esse período são provenientes, basicamente, de pesquisas arqueológicas.

Segundo Fernandez Ochoa \& Morillo Cerdán (1999: 38),

Este hecho no resulta demasiado sorprendente si tenemos en cuenta que las tropas se desplazaban siguiendo las necesidades de la guerra y que la mayoría de sus acantonamientos debían ser temporales, construidos en madera, con un ajuar muy limitado y en su mayor parte transportable. Por otra parte, muchos de ellos fueron utilizados durante un breve espacio de tiempo, por lo que apenas han dejado restos materiales que pudieran servir como base de la identificación.

Daí a importância dos trabalhos desenvolvidos pela equipe do RomanArmy.eu. Recentemente, essa equipe identificou dois novos acampamentos romanos, provavelmente do tipo "castra aestiva/hiberna", na área ocidental da Galícia em pontos muito próximos à Depressão Meridiana (Figura 2.j): o acampamento romano de Cornado (Negreira) e o acampamento romano de Campos, localizado na margem portuguesa do rio Minho, perto de Vila Nova da Cerveira (COSTA-GARCÍA; BLANCOROTEA; GAGO-MARIÑO; FONTE, 2015a; FONTE, 2015: 57-59; BLANCO-ROTEA; COTA-GARCÍA; FONTE; GAGO-MARIÑO; GONÇALVES, 2016: 293-308).

O acampamento de Cornado (Figura 2.k), pela sua localização, possuía um controle imediato da área circundante e de suas passagens naturais. $O$ sítio

\footnotetext{
49 Esse projeto, que tem sua divulgação através da página da web <http://romanarmy.eu/>, é integrado por um coletivo transdisciplinar de investigadores interessados na temática da Arqueologia do conflito e no estudo do processo de conquista do NO Peninsular por parte de Roma. Os seguintes pesquisadores integram o projeto: José Manuel Costa García (Universidade de Santiago de Compostela), Andrés Menéndez Blanco (Universidade de Oviedo), David González Álvarez (Universidade Complutense de Madri/Durham University), Manuel Gago-Mariño (Universidade de Santiago de Compostela), João Fonte (Consejo Superior de Investigaciones Científicas/University of Exeter), Rebeca Blanco-Rotea (Universidade de Santiago de Compostela), Valentín Álvarez Martínez (Universidade de Oviedo).
} 
arqueológico de Campos (Figura 2.I), localizava-se na margem sul do rio Minho e estava próximo a uma importante via de comunicação romana data da época de Augusto: a Via XIX do Itinerário de Antonino (RODRÍGUEZ COLMENERO; FERRER SIERRA; ÁLVAREZ ASOREY, 2004).

Como nessa área ocorre a presença de várias minas exploradas em época romana (CURRÁS-REFOJOS; LÓPEZ-GONZÁLEZ, 2011: 184), provavelmente, o exército romano esteva presente na área para a construção de infra-estruturas viárias (FONTE, 2015: 59), caso da Via XIX.

Os resultados obtidos parecem corroborar a nossa premissa de partida, entretanto, até o momento não há evidências de conexão entre esses acampamentos, o que dificulta seu enquadramento cronológico e a definição de sua funcionalidade. Mas, por outro lado, são evidências da presença do exército romano na área ocidental do Noroeste Peninsular, de sua proximidade com uma rota natural de comunicação (COSTA-GARCÍA; MENÉNDEZ; GONZÁLEZ; GAGO-MARIÑO; FONTE; BLANCOROTEA, 2015b); e de seu papel crucial como agente da integração regional.

\section{Figura 2.j}

\section{Acampamentos romanos próximos à Depressão Meridiana}

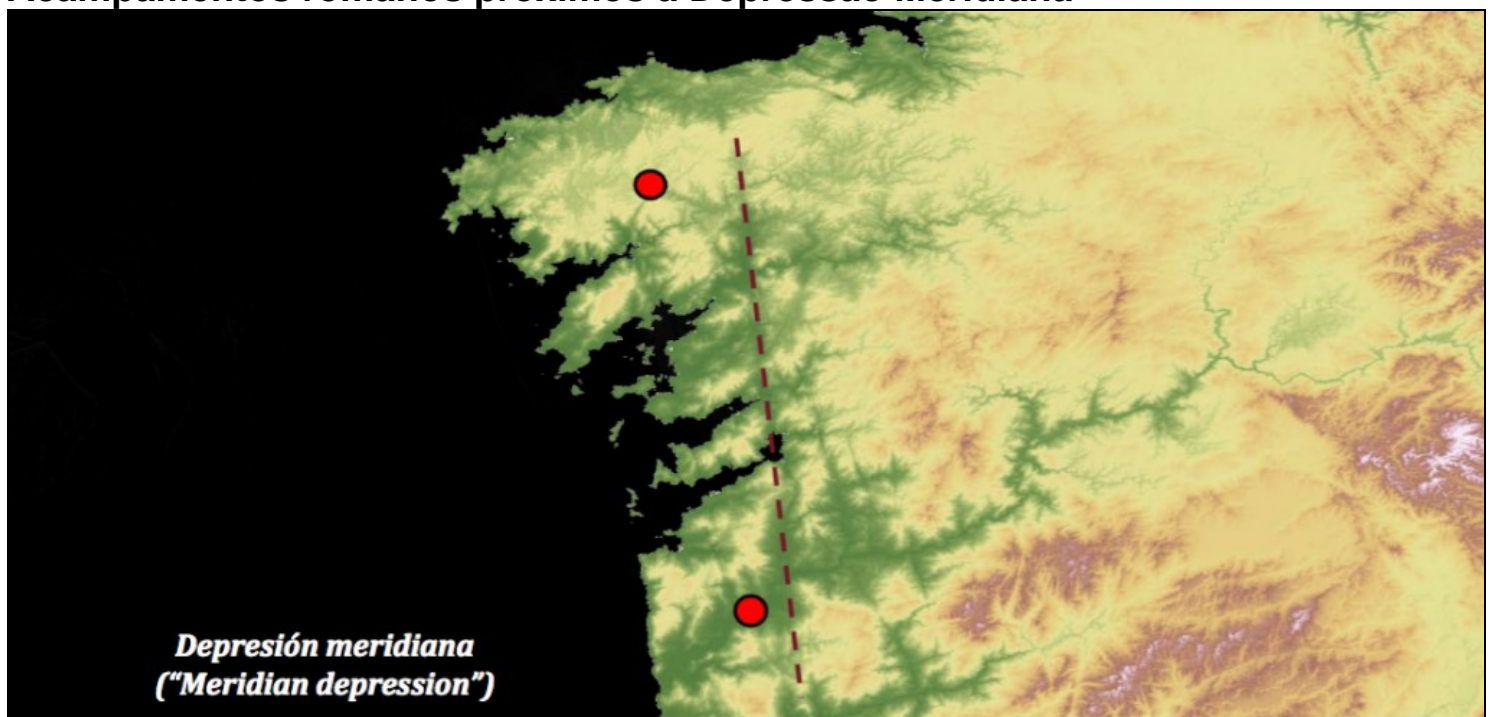

Fonte: Costa-García; Menéndez; González; Gago-Mariño; Fonte; Blanco-Rotea (2015b). 
Figura 2.k

Acampamento romano de Cornado (Negreira)

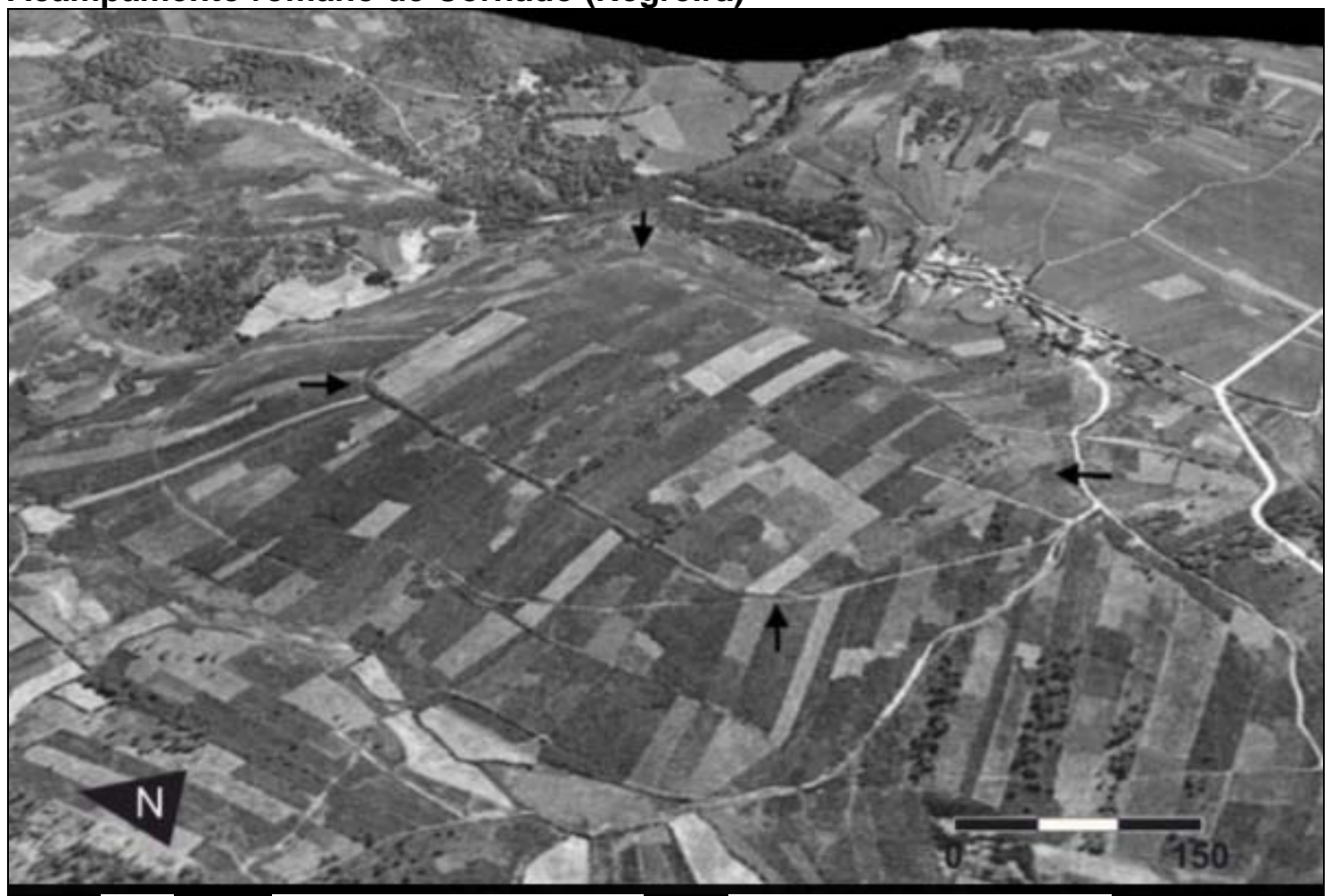

Fonte: Costa-García; Menéndez; González; Gago-Mariño; Fonte; Blanco-Rotea (2015b).

Figura 2.1

Acampamento romano de Campos

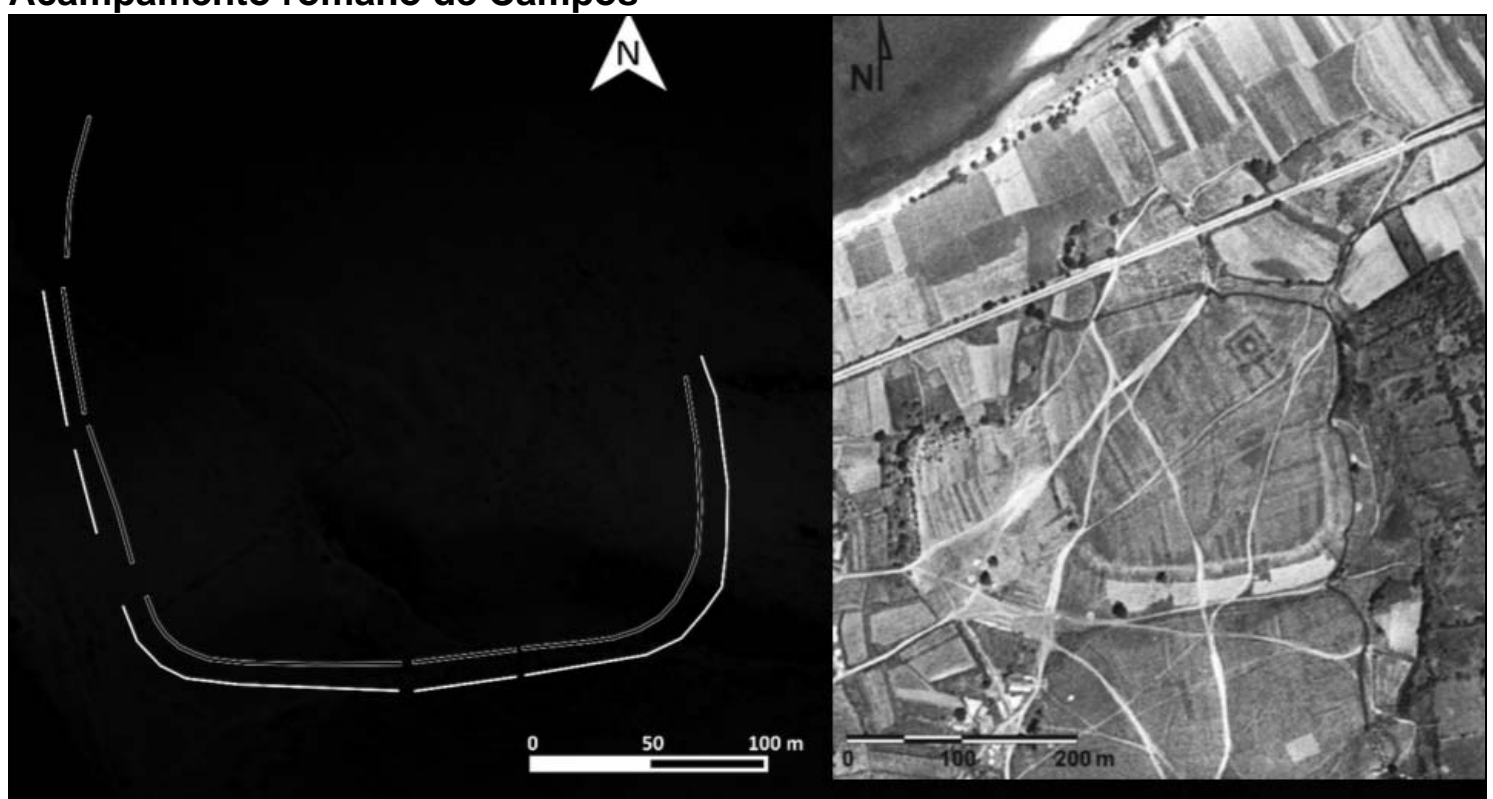

Fonte: Costa-García; Menéndez; González; Gago-Mariño; Fonte; Blanco-Rotea (2015b). 
Apesar dos dados arqueológicos referentes ao período entre os inícios da conquista romana e o período da administração de Augusto ainda serem escassos no Noroeste Peninsular, as descobertas recentes podem ajudar a transformar a imagem do processo de conquista e integração da região.

Provavelmente, a integração total e definitiva desse território ao Império Romano deve ter ocorrido apenas no governo de Augusto em decorrência da reestruturação territorial e administrativa que este efetuou. Contudo, o Noroeste Peninsular com seus respectivos povoados proto-históricos, provavelmente, entraram nominalmente no orbe romano a partir da campanha de Décimo Júnio Bruto. Segundo Arias Vilas (1992: 18):

O território galaico, pois, em orixe entre Douro e Miño, quedaba así reconhecido e explorado polos romanos e, ao tempo, os seus poboadores tomaban contacto cun novo componente cultural que de seguida empezaría a incidir na súa evolución histórica.

Aproximadamente entre 96-94 a.C., e como consequência de uma nova revolta dos Lusitanos, o Pró-Cônsul da Hispania Ulterior, Públio Licínio Crasso, percorre as ilhas da atual Galícia e penetra no interior do território pelas Rias. Nesse trajeto, ele segue a "rota do estanho", com objetivos mais econômicos que militares (TRANOY, 1981: 130). Segundo Ángel Morillo Cerdán (2016: 60), "Craso obtuvo en el 93 a.C. un triunfo "sobre los lusitanos", lo que indicaría, por una parte, que la expedición tuvo una finalidad militar indiscutible y, por outra, que la distinción entre lusitanos y galaicos aún no estaba muy clara".

Outro fator relevante é a importância que as minas de ouro devem ter tido na exploração e organização da região do Noroeste Peninsular. As áreas mais abundantes em ouro e prata estavam localizadas no interior do Noroeste, tanto nas Astúrias e faixa ocidental das províncias de León e Zamora Ocidental, como na Província de Ourense e em Trás-os-Montes (LEMOS, 2009a: 177). Como, por exemplo, o o conjunto mineiro Chaves/Boticas/Montalegre; além de outras, como o complexo mineiro romano de Tresminas e as minas de Campos de Jales (FERREIRA DE ALMEIDA 1970, 1973; SILVA, 2007; QUEIROGA, 1992; LEMOS, 1993; TEIXEIRA, 1996; MARTINS, 2005, 2009); e, sem dúvida, a mina de maior dimensão do Império Romano, a mina de ouro de Las Medulas, que compreende o território de três municípios: Borrenes, Carucedo e Puente de Domingo Flórez. Após a conquista romana, nessas áreas foram instalados os principais territoria metallorum, grandes distritos mineiros, o que levou a um período de exploração exaustiva das ocorrências auríferas (SÁNCHEZ-PALENCIA; OREJAS SACO DEL VALLE, 1998; SÁNCHEZPALENCIA; FERNÁNDEZ-POSSE; FERNÁNDEZ-MANZANO; OREJAS SACO DEL VALLE, 1999; BELLO GARNELO, 2001; SÁNCHEZ-PALENCIA, 2001; FERNÁNDEZPOSSE; MENÉNDEZ; SÁNCHEZ-PALENCIA, 2002; OREJAS SACO DEL VALLE; SÁNCHEZ-PALENCIA, 2002; LEMOS; MEIRELES, 2006; LEMOS, 2009a).

Segundo Pilar Fernández Uriel (1998: 56), a campanha de Décimo Júnio Bruto pode comprovar as riquezas das minas do Noroeste, "uno de los objetivos de esta expedición". E, de acordo com Rodríguez Colmenero (1977: 40), "Roma no dejó de 
tener temprana noticia de la existencia de estos filones de metal precioso, como lo tuvo de las Casitérides y de su riqueza estamnífera y como lo habian tenido los pueblos colonizadores, que la precedieron".

Com uma mentalidade motivada por interesses econômicos, é óbvio que as riquezas mineiras da Península Ibérica não iriam passar despercebidas a Roma, principalmente após as expedições de Bruto e do próprio Júlio César à Gallaecia (PITILLAS SALAÑER, 2000: 86). Percebe-se que, nesse momento, se acentua o interesse econômico e o reconhecimento das possibilidades do Noroeste Peninsular. A campanha de Crasso preparará a expedição que Júlio César realizará em 60-61 a.C. Para Arias Vilas (1992: 18), Crasso abrirá a Roma o caminho das llhas Cassitérides com suas jazidas de estanho e chumbo praticamente à flor da terra.

C. E. Stevens (1970: 295 apud CHIC GARCÍA 1995: 64) comenta no verbete sobre Crassus no The Oxford Classical Dictionary (1970, p. 295) que:

Las Casitérides son diez; están próximas entre sí, al norte de los Artabros, en alta mar (...). Como tienen [sus pobladores] minas de estaño y plomo cambian estas materias, así como sus pieles, por cerámica, sal y utensilios de bronce con los mercaderes Atites eran los fenicios los únicos que explotaban este comercio desde Gádira, ocultando a todos su ruta; y en una ocasión en que los romanos siguieron a un navegante para conocer también ellos el emporio, el navegante, por celo, encalló voluntariamente en un bajío, y después de arrastrar a su misma perdición también a sus perseguidores, se salvó de entre los restos del naufragio y recibió del erario público el precio de las mercancías que había perdido. Pero los romanos lo intentaron muchas veces hasta que lograron descubrir la ruta. Y una vez que Publio Craso hizo la travesía y supo que los metales se extraían a poca profundidad y que los hombres eran pacíficos, indicó detalladamente la ruta [hispana] a los que deseaban surcar este mar aunque era mayor que el que los separaba [desde Galia] de Britania.

Segundo Naveiro López (1991: 130):

Oestrímnidas y Cassitérides son conceptos abstractos aplicados a distintos lugares concretos, todos ellos alejados en el Océano y de los que procede el estaño. No obstante fue entonces, seguramente, cuando se produjeron los primeros contactos directos, viajes exploratorios, tipo "periplo», desprovistos de transcendencia comercial, pero que proporcionaron el fundamental conocimiento costero que permitió posteriormente determinar la ruta.

As informações sobre a expedição de Júlio César são provenientes, principalmente, de Dión Cassio (37, 52-53). Assim, em 61-60 a.C., retornam as notícias sobre ações militares de envergadura, agora direcionadas ao Entre Douro e Tejo, concretamente ao Mons Herminius, provavelmente uma designação genérica das regiões montanhosas do Centro de Portugal (FABIÃO, 2012: 27).

A campanha de Júlio César teve, provavelmente, um duplo objetivo: um militar, contra os Lusitanos; e outro econômico, seguindo a "rota do estanho", pelo interior e pela costa, aproveitando as rotas abertas anteriormente por Bruto e Crasso (TRANOY, 
1981: 131-132; ALARCÃO, 2002: 25-26; RODRÍGUEZ COLMENERO, 1977: 40-42; 1991: 107-108).

As fontes textuais, principalmente Dión Cassio (37, 52-53), Suetônio (César, 18) e Plutarco (César, 12), informam que a expedição de Júlio César foi uma "rapina" (RODRÍGUEZ COLMENERO, 1991: 107). Para Arias Vilas (1992: 19), "César, necesitado de sona, de prestixio e, sobre todo, de diñero para pagar aos seus acredores en Roma, apoiado pola familia gaditana dos Balbos, emprende unha campaña contra os lusitanos na percura de victorias e de botín [...]".

Para Rodríguez Colmenero (1977: 42), a expedição de César foi punitiva e não de conquista, já que a região referente à Lusitania e Gallaecia meridional era conhecida desde a campanha de Bruto. $O$ autor também relata as razões econômicas dessa expedição:

Llegó a tocar también tierras remotas del norte de lo que sería la futura Gallaecia, no sabemos si por simples motivos militares o por razones económicas y comerciales, como parece más presumible, buscando metales preciosos y las legendarias Casitérides, ya que no es un secreto para nadie, por otra parte, que César llegó a la península profundamente endeudado y que sólo la fianza de Craso le permitió escapar de las garras de sus numerosos acreedores romanos. Ya en Hispania trabó fructífera amistad con los Balbos de Cádiz, los que, según parece, tuvieron buena parte en la realización de sus expediciones militares.

\section{Segundo Chic García (1995: 62),}

(...) ya en 61 a.C., cuando había comenzado a hacer valer su fuerza en el escenario político romano, G. Julio vuelve como gobernador a la Provincia Hispania Ulterior, donde había sido cuestor en 68, y enseguida emprende acciones militares en la zona de Lusitania con el pretexto de erradicar el bandolerismo, pero en realidad para buscar la gloria por un lado y riquezas por otro para poder pagar sus inmensas deudas, avaladas por Craso en Roma.

Arias Vilas (1992: 19) complementa que "en todo caso, a xeira de César serviu para encher as súas arcas e para comprovar as riquezas mineiras da Galicia, en especial o ouro, xa daquela de grande sona en todo o Occidente".

Após a batalha do Monte Hermínio, Júlio César teria avançado rumo ao Golfo Ártabro e percorrido o conjunto das Rias de Ferrol, Betanzos e A Coruña. O limite de sua incursão teria sido Brigantium (A Coruña). Para Chic García (1995: 62), os conhecimentos dos marinheiros gaditanos sobre a rota atlântica deve ter desempenhado um papel fundamental nessa expedição:

(...) El hecho de que antes de emprender la expedición implorase la protección del Hércules gaditano; de que llevase a L. Comelio Balbo consigo, en calidad de praefectus fabrum; y de que emplease barcos gaditanos en la toma de una isla (...), nos hace ver que la relación con Cádiz fue básica en esta expedición atlántica que le habría de llevar hasta el centro distribuidor de Brigantium. Por otro lado Gades, enclave oriental en el extremo Occidente, era la puerta del Atlántico, el punto de partida hacia un 
mundo ignoto pero que se presentía lleno de posibilidades, lo que no podía dejar indiferentes a hombres, como César (...).

Segundo Plutarco (César, 12), César marchou contra Lusitanos e Galaicos, vencendo-os. A partir daí, alcançou o oceano e submeteu os povos que anteriormente não haviam obedecido aos romanos. Segundo Dión Cássio (37, 52-53), Júlio César navegou até Brigantium, cidade da Gallaecia, e impressionou os habitantes locais com suas embarcações, já que esses nunca haviam visto uma, obrigando-os, assim, a se renderem. Para Rodríguez Colmenero (1977: 41), esses habitantes podem estar relacionados aos povos ainda não conquistados anteriormente, considerando-se que a campanha de Bruto não tenha ultrapassado a fronteira do Minho.

A Figura 2.m traz a representação das duas campanhas romanas, de Bruto e de César, segundo a interpretação de Rodríguez Colmenero (1996: 249). Esse autor, baseando-se nas informações das fontes textuais e de acordo com a abordagem de Syme (1970: 87), deduz que a expedição de Júlio César tenha sido exclusivamente marítima.

A campanha militar de Júlio César marca o final do que ficou conhecido como o "período lusitano" da conquista. Como consequência, a Lusitania fica pacificada até a região do Minho e a Gallaecia, acessível por terra e mar.

Segundo Curras, Sastre \& Orejas (2016: 126):

Las campañas de Julio César suponen una nueva incursión clara en el territorio del Noroeste, tras las que los pueblos que quedaban por someter a los romanos son sojuzgados por la fuerza de las armas, consiguiendo reducir el territorio en su totalidad al poder de Roma y obteniendo un gran botín. Como resultado el senado lo recompensó con un triunfo. 
Figura 2.m

Campanhas de Décimo Júnio Bruto e Júlio César

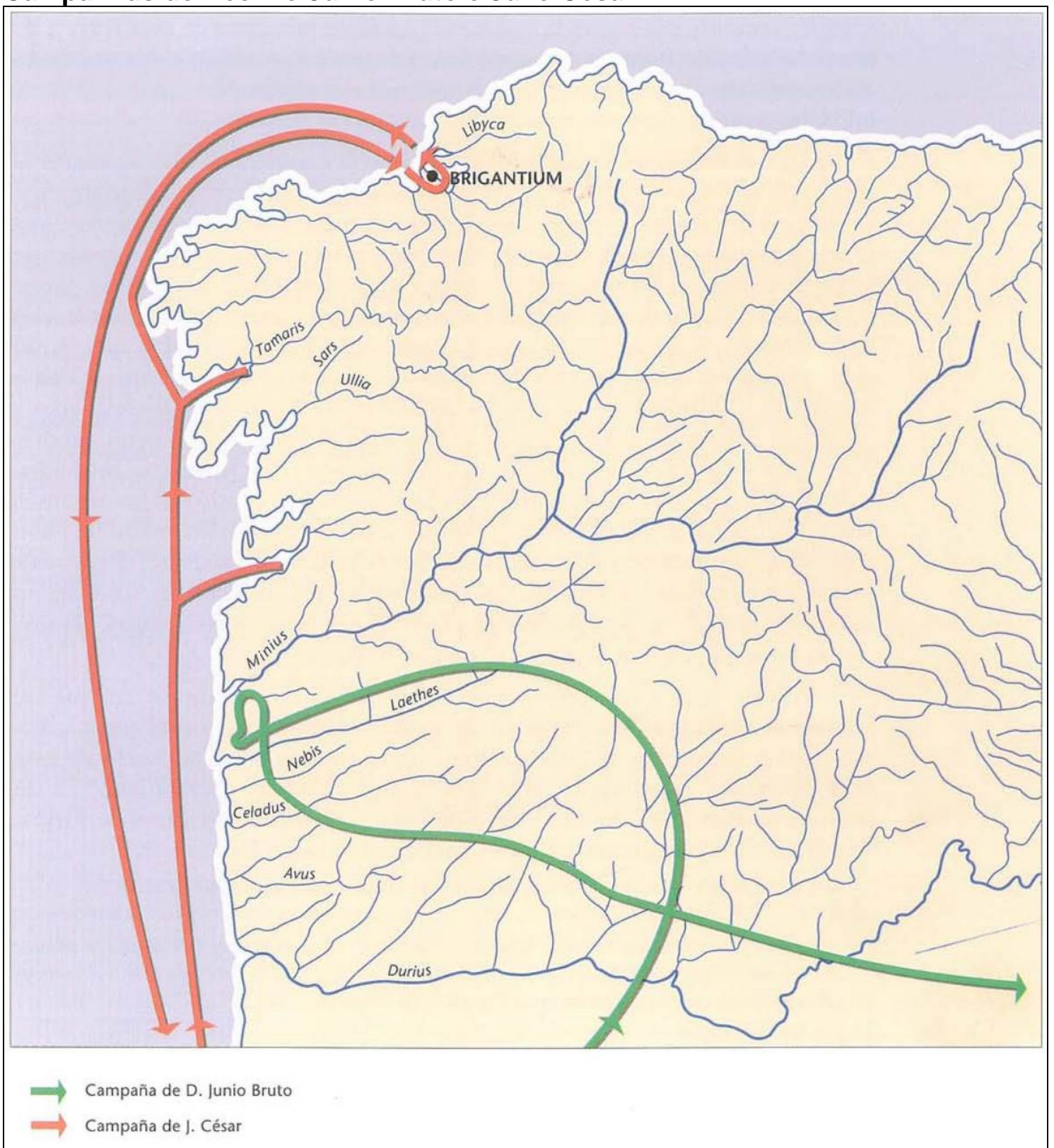

Fonte: Rodriguez Colmenero (1996: 249).

Pelos dados levantados, não podemos considerar que existisse, até então, um plano unitário de ação geoestratégica por parte da elite senatorial romana (SÁNCHEZ; AGUILERA, 2013: 234-237). Segundo Pilar Fernández Uriel (1998: 61),

La lenta imposición de Roma exigía establecerse sobre una estructura urbana que al principio se destacó por la ausencia de una programa estratégico y determinado, dado más a la improvisación y moviéndose de acuerdo con las circunstancias. 
Entretanto, a partir da combinação de informações provenientes de fontes literárias, de novas formas de povoamento e de novas descobertas no registro material, podemos estabelecer suposições sobre algumas formas de controle territorial e social romanas relacionadas com a realidade da expansão republicana na Hispânia.

Assim, temos que considerar que as mudanças observadas a partir do $\|^{\circ}$ século a.C. também podem ser contextualizadas no âmbito da atividade militar romana na área (Figura 2.n), haja vista que os acampamentos militares foram os primeiros assentamentos romanos na região. Para Morillo Cerdán (2003b: 83), "el origen del desarrollo urbano en el norte de la Península se relaciona directamente con la presencia del ejército romano durante e inmediatamente después de las guerras cántabras".

Contudo, tendemos a concordar com Gonçalo Cruz (2014: 414), quando diz que "Foram, de facto, dinâmicas indígenas, mais ou menos influenciadas por fatores exteriores, que conduziram ao aparecimento dos primeiros assentamentos que, no Noroeste Peninsular, podemos classificar como urbanos".

Figura 2.n

Assentamentos pré-romanos e as campanhas de Décimo Júnio Bruto e Júlio César em território galaico

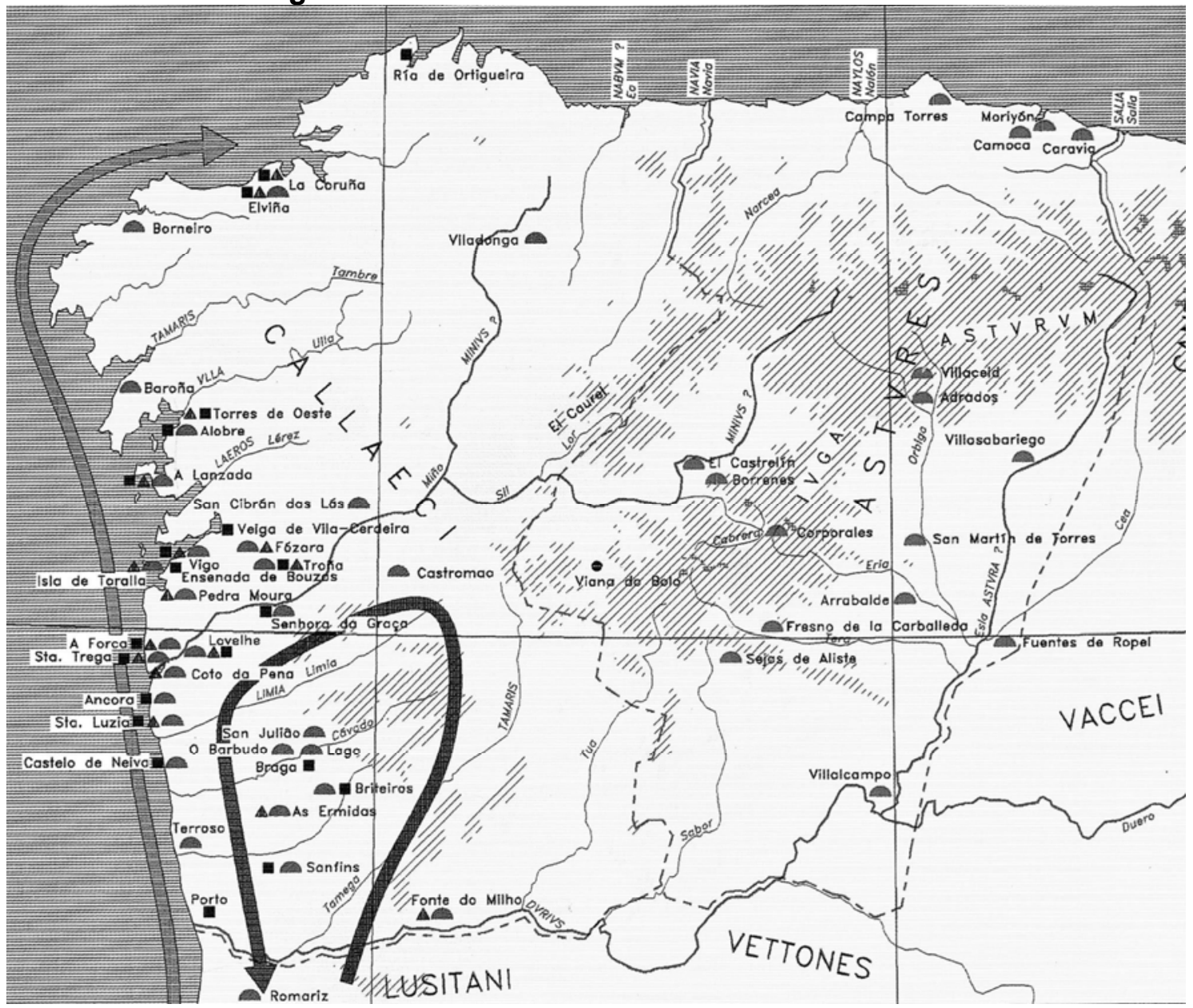

Fonte: OREJAS et al. (2000: 116, fig. 126). 
A conquista definitiva do território em análise, ou seja, o Noroeste Peninsular, abrange o contexto das guerras cântabro-astures - que, obviamente, se enquadram num quadro maior dessa integração.

De acordo com Pilar Fernández Uriel (1998: 60), os motivos que resultaram nas guerras cântabras podem ser vários:

la explotación de los recursos mineros de la cornisa cantábrica, evitar el bandolerismo y la inestabilidad en aquella zona, el proprio prestigio militar de Augusto con su participación personal y sobre todo, el establecimiento definitivo de la paz y la prosperidad en un único Imperio con un único Princeps, una de las bases de la propaganda oficial augústea.

Apesar do Noroeste Peninsular já estar sujeito a importantes processos de transformação pelo menos desde o século II a.C., ainda não havia o controle político efetivo por parte do Império Romano que possibilitaria a organização da exploração de suas riquezas em seu benefício (ARIAS VILAS, 1992: 20). Para Helena Carvalho (2008: 84), "tal transformação abrangeu processos de mudança muito variados e a utilização de alguns territórios como espaços 'laboratoriais' privilegiados”.

Era necessário sistematizar os mecanismos de controle e exploração do império de modo a garantir o fluxo de recursos proveniente das províncias e superar as limitações de "economia de guerra" que haviam caracterizado a expansão republicana (ÑACO, 2003).

Além disso, existem notícias de revoltas e sublevações contínuas durante a fase "Astur-Cántabra" da conquista. As informações das guerras dirigidas por Roma contra Cântabros e Astures chegaram por meio dos escritos de Floro, Orósio e Díon Cássio, que relatam esse foco de resistência na Península. Floro $(I I, 38,48)$ relata que:

En Occidente, casi toda Hispania estaba pacificada, a excepción de la parte que toca las últimas estribaciones de los Pirineos y que baña el océano Citerior. En esta región vivían pueblos valerosísimos, los cántabros y los astures, que no estaban sometidos al Imperio. Fueron los cántabros los primeros que demostraron un ánimo de rebelión más resuelto, duro y pertinaz. No se contentaron con defender su libertad, sino que intentaron subyugar a sus vecinos los vaceos, turmogos y autrigones a quienes fatigaban con frecuentes incursiones. Teniendo noticias de que su levantamiento iba a mayores, César no envió una expedición, sino que se encargó él mismo de ella. Se presentó en persona en Segisama e instaló allí su campamento. Luego dividió al ejército en tres partes e hizo rodear toda Cantabria, encerrando a este pueblo feroz en una especie de red, como se hace con las fieras [...].

Los astures por ese tiempo descendieron de sus nevadas montañas con un gran ejército [...] y se prepararon a atacar simultáneamente los tres campamentos romanos. La lucha contra un enemigo tan fuerte, que se presentó tan de repente y con los planes tan bien preparados, hubiera sido dudosa, cruenta y ciertamente una gran carnicería, si no hubieran hecho traición los brigicinos [...]. Estas luchas fueron el final de las campañas de Augusto y el fin de la revuelta de Hispania. 
Essa resistência era muito problemática para a manutenção da estabilidade dos territórios dominados. Dessa forma, Augusto percebe que a conquista desse foco indígena era essencial e se empenha pessoalmente, a partir de 27 a.C. Além de esse empreendimento significar ganho de prestígio pessoal e fortalecimento político, outro fator importante, obviamente, foi o controle das riquezas auríferas da região (TRANOY, 1981: 134; ROLDÁN HERVÁS, 1995: 225-227).

Como apontado por Salinas De Frías (1998: 156), esse empenho por parte de Augusto teve grande importância porque com ele relaciona-se "toda una propaganda del príncipe que [...] realzaba su persona". Além do aspecto econômico das Guerras Cântabras - inerente a qualquer campanha de conquista -, o desenvolvimento dessa ideologia, em torno do Princeps, será a base da nova política romana. Para Morillo Cerdán (1995), a atenção dada pelas fontes literárias às guerras cântabras "actuaron como una caja de resonancia de las virtudes y excelencias del princeps".

Segundo Arias Vilas (1992: 21), entre as razões da política expansionista de Augusto, além do ganho de prestígio social, também estariam a proteção das áreas conquistadas, especialmente o "celeiro" da Meseta, que era vítima de pilhagens de povos ainda não submetidos; e, a mais provável, que motivos econômicos levaram Augusto a conquistar a Hispânia: "con ela podería Roma explotar as riquezas naturais do país, especialmente os filóns auríferos, que lle permitiran um certo desafogo económico que respaldasse a súa política".

As chamadas Guerras Cântabras (Figura 2.o) afetaram, principalmente, os territórios astur-leonês e cântabro, enquanto a área galaica, já mais "permeabilizada" pelas expedições e contatos anteriores, teria ficado como base de retaguarda e ligação com a área lusitana (ARIAS VILAS, 1992: 21$)^{50 .}$

Autores como Fernández Ochoa \& Murillo Cerdán (1999) apontam qua a área da Galícia Meridional se manteve afastada dos últimos confrontos militares que se desenvolveram na Cordilheira Cantábrica; entretanto (1999: 40):

"Por su proximidade geográfica, el território oriental de los galaicos sin duda se encontro muy vinculado a la conquista y sometimiento de los pueblos astures, especialmente de los habitantes del sector costeiro o transmaontano, desempenando um papel táctico de retaguardia".

Para Martins et al. (2005: 281), esse afastamento dos confrontos militares acabou por beneficiar a região bracarense devido ao fato desta ter conhecido uma influência romana precoce.

\footnotetext{
50 Segundo Rodríguez Colmenero (1979: 13 ss.), em relação aos termos Lusitania e Gallaecia: o primeiro deles pode ter três significados: Lusitania etnia, Lusitania região e Lusitania província. Enquanto que para a Gallaecia teríamos um duplo componente: a Gallaecia etnia e a Gallaecia região.
} 
Figura 2.0

A última fase da conquista do Noroeste pelo exército romano - As Guerras Cântabras (26-25 a.C.)

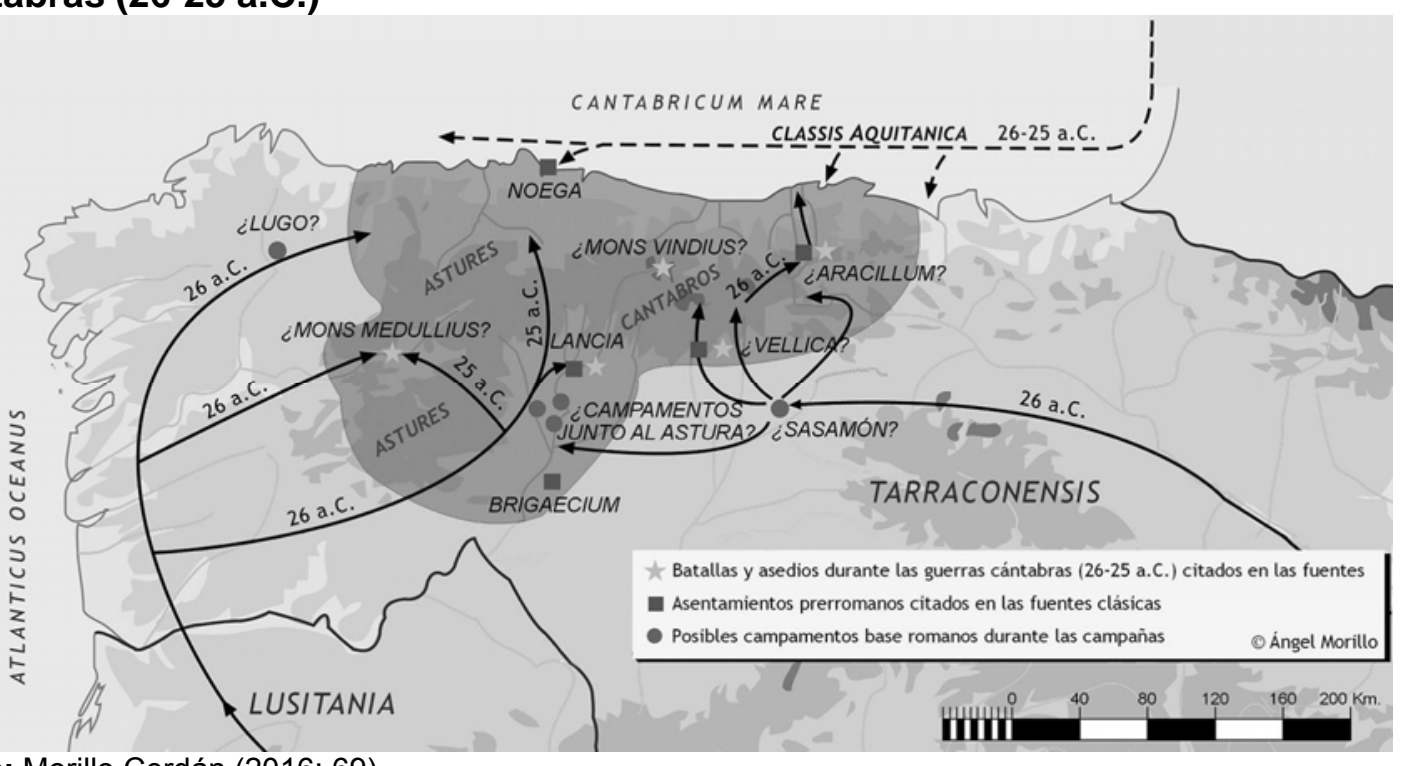

Fonte: Morillo Cerdán (2016: 69).

Em relação à movimentação das operações no contexto das Guerras Cântabras, os pontos de discórdia nas fontes literárias são diversos. De acordo com Tranoy (1981: 65-ss.), Floro e Orósio confundiram operações, cronologia e nome de generais; Dion Cássio também não seria completamente confiável.

A partir dos dados fornecidos pelas fontes textuais, podemos sintetizar as campanhas militares das Guerras Cântabras assim:

O plano de Augusto consistiu em utilizar as legiões I Augusta, IV Macedonica, V Alaudae (em área cântabra); e as X Gemina e VI Victrix (em área lusitana). As fontes textuais ilustram o cenário principal em três colunas: uma com base operativa em Bracara; outra em Asturica e a terceira em Segisamo (Sasamón, Burgos). Essas colunas foram enviadas por Caio Antístio, Públio Carísio e pelo próprio Augusto enquanto completava o ataque por mar sobre a costa cantábrica.

As dificuldades de deslocamento no terreno (pouco propício para o desenvolvimento das táticas militares romanas), somadas ao caráter aguerrido dos indígenas, complicaram a campanha, obrigando Augusto, já adoecido, a regressar à capital da província, Tarraco. Será Antístio quem, finalmente, submeterá os cântabros por meio de vitórias em Vellica, Mons Vindius e Aracillum.

Em 25 a.C., P. Carísio age a partir da Lusitania, assentando sua base de operações, provavelmente, em Asturica e, posteriormente, em Lucus. Finalmente, submete os astures com a derrubada de Lancia (León), após o cerco e a vitória no Monte Medulio.

Posteriormente, e até 19 a.C., os generais C. Fúrnio e Agripa atuam na região, submetendo os últimos rebeldes astures e cântabros, dando-se por pacificada e conquistada a área do Noroeste com a edificação das Aras Sestianas, em 16 a.C., em honra a Augusto, tendo essas sido situadas, provavelmente, no Cabo Torres (Gijón). 
Pelas informações das fontes literárias, extremamente resumidas na síntese acima, observa-se que o papel do atual território da Galícia foi, provavelmente, mais como uma base de operações (com provável acampamento em Lucus Augusti), do que um cenário de batalhas. Ainda mais complicado que relatar os eventos relacionados às Guerras Cântabras, é tentar confrontar essas informações provenientes das fontes textuais com os dados evidenciados arqueologicamente.

Hawkes (1958) situa, no contexto das Guerras Cântabras, a destruição das muralhas da Citânia de Sanfins, devido à descoberta de moedas de P. Carísio em seus arredores. Entretanto, tanto essa informação quanto as relacionadas a Citânia de Briteiros continuam sendo revistas. Segundo Arias Vilas (1992: 23), vários assentamentos castrejos que apresentam níveis de destruição ou de abandono correspondem a esse contexto histórico, "xa debido a accións bélicas concretas, xa por mor de pactos tácitos ou expresos que favorecian o traslado ás ladeiras ou ao fondo dos vales e chairas, cuestión incidente na ocupación do territorio [...]".

A questão do Monte Medulio (Mons Medullius), anteriormente relacionada ao final das Guerras Cântabras e ao episódio do suicídio coletivo dos sitiados, gerou muitas hipóteses sobre a sua localização. Primeiramente, foi identificado com o Monte Aloya, próximo a Tuy (SCHULTEN, 1937: 147); e posteriormente, foi situado na área de Castro de Rei, nas proximidades de Lugo (AMOR MEILÁN, 1918; VÁZQUEZ SEIJAS, 1939). Atualmente, tem sido identificado com a zona de Las Medulas do Bierzo, junto ao rio Sil (SYME, 1970: 102; RODRÍGUEZ COLMENERO, 1977: 47-48).

Os estudos mais recentes sobre as campanhas de Augusto partem da premissa de que a zona galaica "transduriana" já se encontrava sob um domínio romano efetivo (MORILLO CERDÁN, 2002: 71; 2014: 135; MARTINS et al., 2005; FERNÁNDEZ OCHOA; MORILLO CERDÁN, 2015).

As evidências numismáticas apontam para uma presença romana precoce na zona de Bracara Augusta (Braga), devido à quantidade de moneta militaris de "caetra". $\mathrm{E}$ alguns autores sustentam, com base no comércio com a Bética, a completa pacificação e integração na economia imperial no período entre o século I a.C. até Augusto (MORAIS, 2007: 121).

Após 19 a.C., foi mantida na região do Noroeste uma significativa presença militar que era assegurada por duas legiões e vários corpos auxiliares (LE ROUX, 1982: 52-69; TRANOY, 1981: 138-144; MORILLO CERDÁN, 2003b: 81-112), "no en la vigilancia del "indómito indígena", sino en el interés de Roma por las explotaciones auríferas" (FERNÁNDEZ OCHOA; MORILLO CERDÁN, 2015: 184).

Com relação à distribuição dos acampamentos militares, os principais aparecem nas Astúrias e na Cantábria (MORILLO CERDÁN, 2014) e, também, na área leste de Lugo. Para a área meridional, conta-se com o provável acampamento de Antanhol (Coimbra) (OLEIRO, 1959; MORILLO CERDÁN, 2003a: 62); com o de Valado (SÁNCHEZ-PALENCIA; CURRÁS-REFOJOS, 2015); e com o de Lomba do Canho, de meados do século I a.C. (NUNES; FABIÃO; GUERRA, 1988).

Até recentemente, essa distribuição correspondia a um número reduzido de acampamentos militares espacializados no Noroeste Peninsular. Inclusive, indicavam um vazio total para a área da Galícia Meridional (CURRÁS-REFOJOS; SASTRE PRATS; OREJAS SACO DEL VALLE, 2016: 131). 
Entretanto, como já antecipado anteriormente, a equipe multidisciplinar integrada no projeto RomanArmy.eu tem realizado importantes achados através do uso de ferramentas geoespaciais. Como consequência desses estudos, novos sítios arqueológicos estão sendo inseridos nos catálogos desatualizados (COSTA-GARCÍA, 2015; MENÉNDEZ BLANCO; GONZÁLEZ ÁLVAREZ; ÁLVAREZ MARTÍNEZ; JIMÉNEZ CHAPARRO, 2013: 245-251).

Esses estudos demonstram que, com um olhar mais apurado sobre o tema e com a combinação de novas metodologias, poderão ser observados, nas zonas montanhosas da Cantábria, da Astúrias e no norte da Meseta, uma densa distribuição de pontos que correspondem a acampamentos militares romanos (Figura 2.p).

Alguns desses lugares podem estar relacionados com as campanhas hispânicas de Augusto. Outros podem ajudar a compreender alguns dos cenários pré e pósguerra, na transição entre o final da República e os primeiros tempos do Império.

Para uma unidade militar, a maneira mais prática de cobrir grandes distâncias em áreas montanhosas é seguir os picos das montanhas com pendentes mais suaves. $\mathrm{Na}$ área de ligação entre Léon e Astúrias, o caminho histórico conhecido como via da Mesa corresponde a um desses itinerários, um dos principais caminhos de entrada na região das Astúrias. Justamente nessa região foram evidenciados dois acampamentos romanos que, provavelmente, controlariam a passagem da montanha de Valbona (COSTA-GARCÍA, 2015). Trata-se dos recintos de El Xuegu la Bola (Arvechales, Somiedo) e Cueiru (Taxa, Teverga), instalados a 1700 e a 1440 metros de altitude, respectivamente; são os sítios arqueológicos militares romanos localizados em maior altitude na região da Mesa.

Outra via montanhosa liga a província galega de Lugo com a foz do rio Navia, nas Astúrias. Foram localizados três "castra aestiva/hiberna" (acampamentos de campanha, ou seja, tipos de fortificações temporárias ${ }^{51}$ ) nessa área através do uso de fotografia aérea.

Outros cinco sítios militares romanos podem ser relacionados a uma via de acesso à Galícia a partir de Léon, contornando pelos montes ocidentais asturianos. Localizam-se próximos a uma importante via romana de época imperial na área montanhosa que separa León e Galícia.

E outros três recintos militares estão situados na Galícia numa meseta denominada A Chá de Santa Marta. Foram localizados em 2014, depois das fotos USAF de 1956 serem analisadas (COSTA-GARCÍA, 2015).

\footnotetext{
51 Sobre esse tema ver: PERALTA LABRADOR (2002: 49-87).
} 
Figura 2.p

Distribuição dos novos acampamentos militares evidenciados

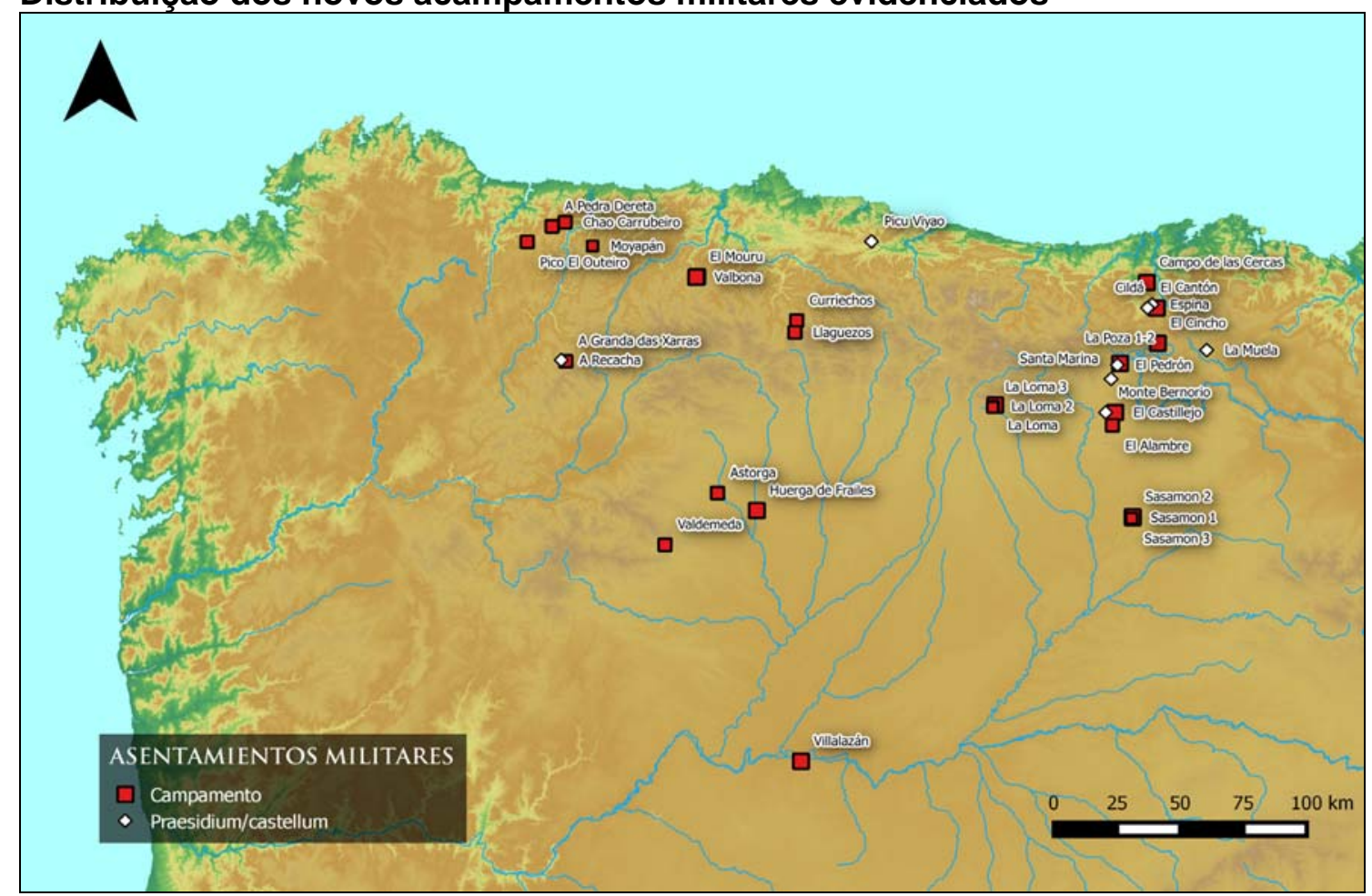

Fonte: Costa-García (2015: 100).

Os dois últimos acampamentos evidenciados pela equipe do projeto RomanArmy.eu já foram comentados anteriormente quando nos referimos à Depressão Meridiana: o acampamento romano de Cornado, localizado na Galícia (Negreira); e o acampamento romano de Campos, localizado na margem portuguesa do rio Minho, perto de Vila Nova da Cerveira (COSTA-GARCÍA; BLANCO-ROTEA; GAGO-MARIÑO; FONTE, 2015a; FONTE, 2015: 57-59; BLANCO-ROTEA; COTAGARCÍA; FONTE; GAGO-MARIÑO; GONÇALVES, 2016: 293-308).

Vários desses sítios podem estar vinculados às campanhas augustas na zona ou com os enfrentamentos contra os indígenas dos anos posteriores. Sabe-se que a base operativa do exército romano estava estabelecida na Meseta Norte e o sítio de Huerga de Frailes (Província de León), localizado próximo a Astorga, poderia estar vinculado aos primeiros momentos da guerra contra os astures.

A presença de vários acampamentos próximos às rotas naturais ou passagens montanhosas, provavelmente, indica o seu uso pelo exército romano como rotas de incursão ou de flanqueio. Essa tática foi identificada previamente na Cantábria e na zona central das Astúrias, mas é a primeira vez que se verifica uma ligação clara com a área do nordeste da Galícia (COSTA-GARCÍA, 2015).

A cidade de Lucus Augusti, capital conventual fundada por Augusto, localiza-se nessa região e foi frequentemente vinculada a essas campanhas nas fontes literárias. A existência de um acampamento prévio, com um caráter logístico, parece agora possível. A presença de pelo menos três acampamentos em A Chá de Santa Marta, 
na Galícia ${ }^{52}$, também demonstra o uso recorrente desse lugar como uma base de operações do exército romano. E os acampamentos de Cornado e Campos são os primeiros detectados na área ocidental da Galícia, e também estão relacionados com uma importante rota natural, a Depressão Meridiana.

Ainda que a interação com a população local e a cultura romana estejam documentadas arqueologicamente em alguns castros dessa zona, não sabemos exatamente quando foram efetivamente anexados pelos romanos, e/ou se essa incorporação foi pacífica. Como as campanhas de Augusto tiveram seu foco nos territórios das Astúrias e Cantábria, esses acampamentos poderiam pertencer ao final da República, ao triunvirato ou ao princípio do período imperial, quando foram construídas as primeiras infraestruturas romanas e se iniciou a exploração dos recursos naturais locais.

52 Atualmente, a equipe do projeto RomanArmy.eu realiza atividades de prospecção arqueológica no sítio arqueológico de Outeiro de Arnás, localizado em Verín (Ourense), na Galícia. Nessa área foram encontrados cravos das sandálias (caligae) utilizadas pelos legionários. Mais informações através da página da web <http://romanarmy.eu/> 


\section{CAPÍTULO 3. ORGANIZAÇÃO ADMINISTRATIVA E TERRITORIAL}

\subsection{O Noroeste Pré-romano: Síntese Interpretativa}

O objetivo nas próximas linhas é apresentar uma síntese dos conhecimentos atuais sobre a Idade do Ferro no âmbito do Noroeste Peninsular, considerando-se as variações regionais em termos de padrões de povoamento, dimensão e cronologia desses povoados, do aproveitamento dos recursos econômicos e de sua organização social ${ }^{53}$. Portanto, não se trata de realizar um estudo aprofundado da denominada "cultura castreja", nem tampouco elaborar uma análise historiográfica ${ }^{54}$.

Nos últimos anos, os estudos direcionados a investigação sobre a Idade do Ferro no Noroeste Peninsular tem fornecido novos dados que tem permitido a elaboração de discursos atualizados sobre as dinâmicas sociais vividas pelas comunidades proto-históricas. As novas linhas de pesquisa propõem uma nova imagem dessas comunidades a partir de uma tríplice abordagem (AYÁN VILA, 2013: 39):

1. Aplicação de metodologias próprias da Arqueologia Espacial (análises de povoamento, território, espaço interno dos povoados), complementadas com as geotecnologias (SIG, LiDAR, etc);

2. Suposição do quadro teórico das Arqueologias críticas;

3. Aplicação de modelos antropológios para interpretar o surgimento e evolução da paisagem fortificada.

O ponto de partida desses trabalhos tem como eixo principal as análises espaciais, em particular, aquelas que adotam a perspectiva da Arqueologia da Paisagem. Esse enfoque, ao se basear em uma análise integral de assentamentos e territórios, resulta adequado para esse tipo de aproximação. Para Francisco Sande Lemos (2009a: 125),

(...) os castros são indissociáveis da paisagem envolvente, dos territórios em que foram implantados, pelo que o seu estudo implica, forçosamente, um profundo conhecimento das diferentes regiões pelas quais se distribuem. (...) O estudo dos castros é também a análise da sua inserção no espaço, no relevo, das suas inter visibilidades, das paisagens e da forma como estas foram estruturadas ao longo dos milénios...

\footnotetext{
53 Sobre este assunto consultar as seguintes obras: a Tese de Doutorado de F. Sande Lemos (1993); a Tese de Doutorado de Manuela Martins (1990); a síntese de $\mathrm{M}^{\mathrm{a}}$. D. Fernández Posse (1998); a Tese de Doutorado de I. Sastre Prats (1999); o trabalho de B. Díaz Santana (2002); a Tese de Doutorado de A. González Ruibal (2006-2007); a Tese de Doutorado de Helena Carvalho (2008); a síntese de F. Sande Lemos (2009a); a Tese de Doutorado de C. Marín Suárez (2012); a Tese de Doutorado de X. M. Ayán Vila (2012); e a Tese de Doutorado de João Fonte (2015).

${ }^{54}$ Como é uma síntese foi feita uma seleção dos pontos que consideramos mais relevantes, pois, de acordo com P. Veyne (1971: 51), trata-se de tarefa impossível descrever uma totalidade e toda descrição é seletiva.
} 
Durante a década de 1980, desenvolveram-se diversos trabalhos no âmbito da Arqueologia Espacial, tanto na Galícia como no norte de Portugal, o que propiciou a consolidação de uma problemática sobre a evolução do povoamento e do território no Noroeste Peninsular como principal objeto de estudo dos setores acadêmicos mais ativos da Arqueologia no Noroeste: a Universidade de Santiago de Compostela, na Galícia (ACUÑA CASTROVIEJO, 1989; PÉREZ LOSADA, 1991; XUSTO RODRÍGUEZ, 1993; CARBALLO ARCEO, 1993); e as Universidades do Porto (ALMEIDA, 1981, SOEIRO, 1984, SILVA, 1986) e do Minho (MARTINS, 1988a; 1988b; 1990; LEMOS, 1993), no norte de Portugal.

Manuela Martins (1988a: 19-20), sobre as pesquisas arqueológicas do mundo castrejo no norte de Portugal nesse período, diz que:

\begin{abstract}
Muito embora exista un número razoável de povoados escavados de forma extensa, é um facto que pouca atenção tem sido voltada ao seu estudo sistemático. As razões que justificam tal atitude prendem-se com a complexidade estratigráfica destas estações, ocupadas muitas delas ao longo de séculos e com a sua dimensão. No entanto, tais dificultades não deverão inviabilizar uma tentativa séria de reconstitução antropológica dos sítios. Ela será exequível pelo menos nalgumas fases, nomeadamente nos finais do $1^{\circ}$ milénio a. C., momento em que um registo arqueológico mais expressivo favorece análises detalhadas da organização espacial das comunidades.
\end{abstract}

Nesse contexto acadêmico, esses trabalhos investigativos levaram à uma reformulação teórica que teve como consequência o fortalecimento de um novo enfoque disciplinar, a denominada Arqueologia da Paisagem. É dentro dessa perspectiva que, ao final da década de 1980 e durante a de 1990, se realizaram projetos científicos em uma escala territorial como, por exemplo: o levantamento exaustivo realizado por Francisco Sande Lemos na região de Trás-os-Montes Oriental (LEMOS, 1993); a pesquisa de Manuela Martins no vale do rio Cávado (MARTINS, 1990); e o projeto coordenado por Sánchez-Palencia e $M^{a}$ Dolores Fernández Posse na Zona Arqueológica de Las Médulas, no noroeste da Província de León, Espanha (SÁNCHEZ-PALENCIA et al. 1994; FERNÁNDEZ-POSSE et al. 1994; SÁNCHEZPALENCIA et al. 1996; FERNÁNDEZ- POSSE; SÁNCHEZ-PALENCIA, 1997; SASTRE 1998).

Um ponto a ser destacado é que, no âmbito da arqueologia galega, nas últimas duas décadas, boa parte do registro arqueológico sobre os castros é proveniente de intervenções da chamada Arqueologia Preventiva ${ }^{55}$, ou seja, de projetos realizados por empresas de consultoria em Arqueologia, coordenados por arqueólogos que empregam procedimentos metodológicos mais atualizados, entre eles a perspectiva da Arqueologia da Paisagem (AYÁN VILA, 2012: 162). Esse resultado só é possível quando ocorre uma gestão integrada do patrimônio ou seja, quando ocorre uma associação entre administração pública, academia e empresas privadas.

\footnotetext{
${ }^{55}$ A Arqueologia Preventiva, ou de Contrato, está relacionada com atividades de avaliação e mitigação de impactos decorrentes de obras, públicas ou privadas, com o objetivo de proteger o patrimônio arqueológico e cultural.
} 
Segundo Ayán Vila (2012: 156),

(...) a la altura de 1989, el ámbito de actuación que empezaba a ser priorizado por la Administración autonómica - ente que subvencionaba prácticamente la totalidad de las intervenciones arqueológicas en Galicia era el de la conservación y presentación al público de los yacimientos arqueológicos y la necesidad de implementar estrategias de corrección del impacto arqueológico de infraestructuras a escala territorial. Así pues, de los 54 proyectos de la campaña de 1989, 16 son intervenciones de urgencia, 8 actuaciones de consolidación de yacimientos, y 3 proyectos de intervención territorial, entre los que destaca la corrección de impacto arqueológico en el área minera de As Pontes y en la zona afectada por el embalse de Lindoso en A Baixa Limia.

Entretanto, Ayán Vila (2012: 37-38) enfatiza que "Sólo la apertura de nuevos yacimientos, la revisión metódica de los materiales antiguos y las excavaciones en área podrán ampliar el registro disponible y abordar más detalladamente el mundo castrexo".

Dessa forma, a denominada "Cultura Castreja" já não é mais percebida da mesma forma como foi até finais da década de 1980 e inícios da década de 1990, ao ponto de se negar a validade desse conceito histórico-cultural obsoleto, relacionado ao suposto celtismo ${ }^{56}$ das comunidades indígenas pré-romanas do Noroeste (MARTINS, 1993; AYÁN VILA, 2012).

O conceito de "Cultura Castreja" é tão controverso quanto o conceito de "Romanização". Alguns pesquisadores preferem utilizar esse termo entre aspas; outros preferem o anteceder com o termo "a denominada"57; e alguns preferem utilizar um termo mais neutro, como Manuela Martins (1990), ao optar por 'povoado fortificado'.

De acordo com Lemos (2009a: 127),

Despojada de conotações históricas e culturais, tanto a palavra Castro como expressão Cultura Castreja constituem conceitos operativos eficazes a que recorrem numerosos arqueólogos. (...) O termo Cultura Castreja, apesar de todos os equívocos, é uma plataforma confortável para se navegar num universo imenso de interrogações.

Esse debate proporcionou o reconhecimento da diversidade da Proto-História do Noroeste Peninsular, sendo um ponto de partida essencial (CARBALLO ARCEO; GONZÁLEZ RUIBAL, 2003; CARVALHO, 2008; LEMOS, 2009a). Portanto, está cada vez mais claro nas evidências arqueológicas que existiram realidades contemporâneas diferentes, dentro de um quadro heterogêneo das sociedades rurais estruturado em

\footnotetext{
${ }^{56}$ As obras de Lopéz Cuevillas (1953; 1956), como de outros estudiosos galegos, difundiram a ideia de que a Cultura Castreja seria um produto da "civilização" celta. Como não é nosso intuito aprofundar essa questão emblemática, para informações sobre esse debate consultar os seguintes autores: González Ruibal (2006-2007); Lemos (2009a); Ayán Vila (2012).

${ }^{57}$ Nessa pesquisa utilizamos esse termo tanto entre aspas, como antecedido da expressão 'a denominada'.
} 
função de processos gerados em escala territorial (GONZÁLEZ RUIBAL, 2006-2007; CARVALHO, 2008; LEMOS 2009a; FONTE, 2015).

Segundo Helena Carvalho (2008: 66),

As mudanças registadas mostram um quadro de conhecimentos que ultrapassou a aparente homogeneidade da chamada "cultura castreja", permitindo diferenciar regiões, aferir cronologias e ter uma apreensão mais clara das diferentes situações com que o poder romano foi confrontado em finais do I milénio a.C.

O Noroeste Peninsular compreende uma vasta área que, além de abranger uma zona fronteiriça, corresponde ao norte de Portugal e as regiões da Galícia e Astúrias, bem como a faixa ocidental das províncias de León e Zamora (Autonomia de CastillaLeón), na Espanha. O pesquisador português F. Sande Lemos (2009a; 2009b; 2012), compreende o Noroeste Peninsular o delimitando ao Sul pelo Douro português; ao Leste pelo Douro Internacional, rio Esla e Picos da Europa; a Oeste e ao Norte pelo Oceano Atlântico. Portanto, essa área apresenta uma grande diversidade ambiental, com características distintas, tanto em relação aos aspectos climáticos, como os geológicos ou orográficos (LEMOS, 2009b), ou seja, o Noroeste apresenta unidades geográficas muito fragmentadas e contrastantes.

Geralmente, quando se vincula os castros e/ou castrejo com o Noroeste Peninsular acaba-se por excluir "outros territórios castrejos", como, por exemplo, os localizados na área da faixa Cantábrica até os Pirineus (MARÍN SUÁREZ, 2011: 1).

Assim, nos trabalhos sobre a "cultura castreja", é apresentada uma zona nuclear, mais dinâmica, associada ao Noroeste; e uma zona periférica - de transição entre o maciço galaico e a Meseta - na qual as características castrejas se diluem até serem substituídas pelas características mesetanas (MARÍN SUÁREZ, 2011: 2). Marín Suárez (2011), ilustra essa situação a partir de imagens retiradas de alguns trabalhos sobre a "cultura castreja" (Figura 3.1.a).

Figura 3.1.a

Exemplos da representação da "Cultura Castreja" no Noroeste
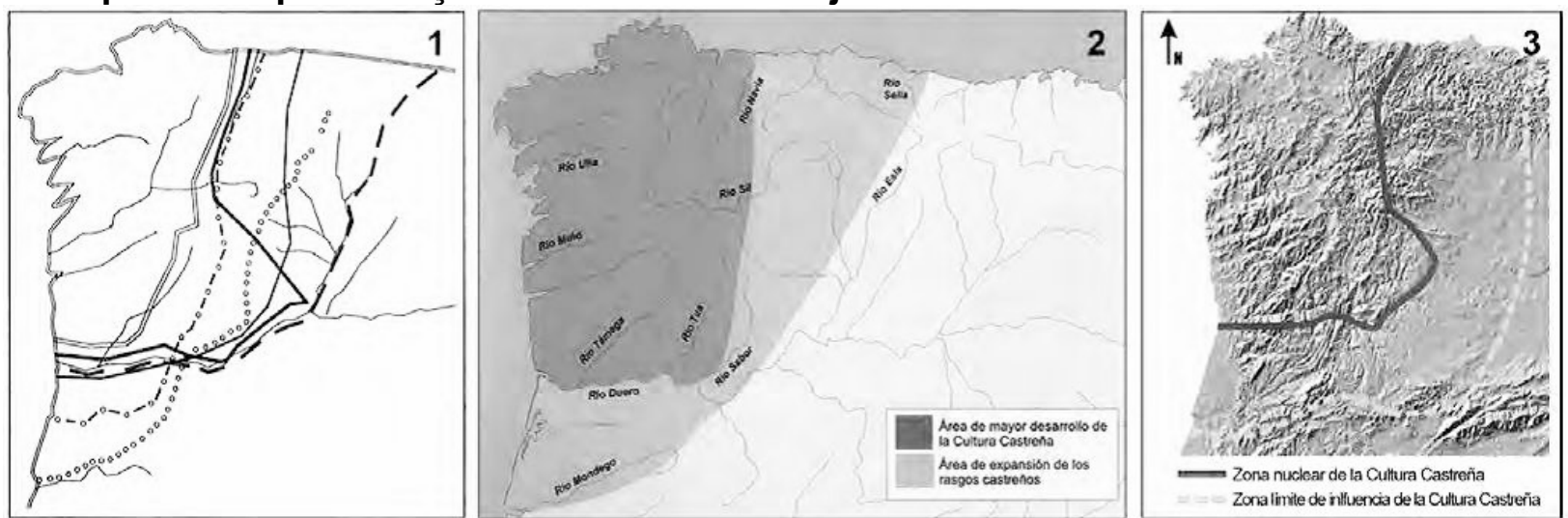

Fonte: (MARÍN SUÁREZ, 2011: 2): Figura 1. Fernández-Posse, 1998; Figura 2. García Vuelta, 2007; Figura 3. Grande Rodríguez, 2008. 
Para Marín Suárez (2011: 1),

(...) ya que por mucho que algunos reconozcan los "polimorfismos regionales" en el fondo se reifica el Noroeste, como si todos los castros se concentrasen en esta zona [galaica] y el resto fueran formas impuras cuyos rasgos característicos se van diluyendo según nos alejamos del núcleo difusor.

No decorrer da Proto-História, nesse amplo espaço representado pelo Noroeste peninsular, constata-se algumas características em comum tanto em relação ao povoamento quanto a cultura material; como, por exemplo, o predomínio de povoados fortificados em altura e trabalhos em ourivesaria (LEMOS 2009b: 110).

Entretanto, também são observadas assimetrias significativas. Essas assimetrias estão relacionadas com a distribuição dos povoados, sua dimensão, sua estrutura, e sua cultura material (CARBALLO ARCEO, 1986; 1990; MARTINS, 1990; BETTENCOURT, 1998; FERNÁNDEZ-POSSE, 1998; VILLA VALDÉS, 2002; GONZÁLEZ RUIBAL, 2006-2007: 84; CARVALHO 2008: 68; LEMOS 2009a; 2009b: 110; AYÁN VILA, 2012; FONTE, 2015).

Essa representação pode ser o reflexo de pesquisas arqueológicas mais desenvolvidas na área que abrange, principalmente, o sul da Galícia e o norte de Portugal. Pelo menos, para a região do Entre-Douro e Minho desde finais do século XIX, em diversos trabalhos de campo e de catalogação os pesquisadores procuraram identificar os castros existentes (CARVALHO, 2008: 25; LEMOS, 2009a: 123).

Contudo, González Ruibal (2006-2007), não as atribui a razões de investigação arqueológica. Segundo este autor, ao se analisar a emergência dos castros na transição do $I^{\circ}$ para o $I^{\circ}$ milênio a.C., constatam-se determinadas zonas, dinâmicas e abertas, com características específicas que perdurarão por toda a Proto-História (2006-2007: 84). No contexto do Noroeste Peninsular, o autor as divide em quatro áreas nucleares (2006-2007: 84):

1) a região do grupo Baiões-Santa Luzia, ao sul do Douro, cuja influência chega até o vale do Cávado;

2) a zona entre-Douro e o Lima/Minho;

3) a zona de Chaves, no centro-norte de Portugal, no entorno do Tâmega; e

4) o setor entre o Lima/Minho e o Ulla (Rias Baixas).

Portanto, já no Bronze Final observa-se uma diversidade de povoados e de formas de ocupação do espaço (CARVALHO, 2008: 68).

Dessa forma, na transição do $\|^{\circ}$ para $01^{\circ}$ milênio a.C., constatam-se duas grandes tradições no Noroeste Peninsular: uma relacionada a fundação de castros ou povoados fortificados em altura na zona sul/ocidental, com as linhas dos rios Sil e Lérez como seu limite mais setentrional; e outra, no restante do território, que representa a manutenção e desenvolvimento das tradições locais do Bronze, ou seja, as formas de povoamento aberto. A zona entre o Minho e o Lérez representaria um 
setor de transição entre as duas áreas (GONZÁLEZ RUIBAL, 2006-2007: 87; CARVALHO, 2008: 67).

Alguns pesquisadores defendem que a "Cultura Castreja" teria sido um fenômeno endógeno (mas com influências exteriores) que surgiu na transição do II $^{\circ}$ para o $I^{\circ}$ milênio a.C., nos parâmetros da chamada Idade do Bronze Final (MARTINS, 1990; GONZÁLEZ RUIBAL, 2006-2007; CARVALHO, 2008; LEMOS, 2009b).

Outros autores sugerem que os castros estariam ligados à uma matriz ancestral Indo-Europeia; e posteriormente integrariam outras movimentações populacionais como teria sido a dos povos Celtas (SILVA, 1986; GARCÍA QUINTELA, 2005; 2012).

Sinteticamente, as principais propostas cronológicas da "Cultura Castreja" foram apresentadas por Armando Coelho da Silva (1986), Manuela Martins (1989/90), Jorge Alarcão (1992) e González Ruibal (2003). Essas propostas apresentam poucas variações entre as datas: no geral, esses autores concordam com uma $\left.\right|^{a}$ Fase, inserida na Idade do Bronze Final e que se estenderia dos séculos $\mathrm{XI} / \mathrm{X}$ a.C. até VIII/VII a.C. (LEMOS, 2009a).

Nesse contexto, verifica-se o surgimento de um outro tipo de habitat, diferente dos povoados abertos característicos da Idade do Bronze. Esses povoados estão localizados em cumes dominantes, ocupando lugares destacados na paisagem, com um amplo domínio estratégico sobre a área envolvente e com grande controle sobre os corredores naturais de circulação (MARTINS, 1996; BETTENCOURT, 2000; 2005; CARVALHO, 2008; LEMOS, 2009a).

Estes povoados, inicialmente, não apresentam estruturas defensivas mas registram elementos delimitadores do seu espaço físico. Posteriormente, passam a ser defendidos por muralhas de terra, ou pedra solta. Abrigam casas sub-circulares, edificadas com alicerces pétreos, mas perecíveis. Uma rica e abundante metalurgia em bronze (pontas de lanças; machados; peças de adornos ou simbólicas) também está associada a esses povoados (LEMOS, 2009a: 127).

É o período em que o castro se constitui como referência fundamental da presença humana na paisagem, representando no Noroeste Peninsular o primeiro assentamento doméstico permanente, petrificado e fortificado. Será também nesse período que os castros começarão a ser instalados nos vales e nas terras baixas.

Na região do Entre-Douro e Minho, os povoados fortificados de altitude mais significativos da Idade do Bronze Final, são o Coto da Pena, em Caminha (SILVA, 1986) e a Citânia de S. Julião (Figura 3.1.b), em Vila Verde (MARTINS, 1988b; BETTENCOURT, 2000). 


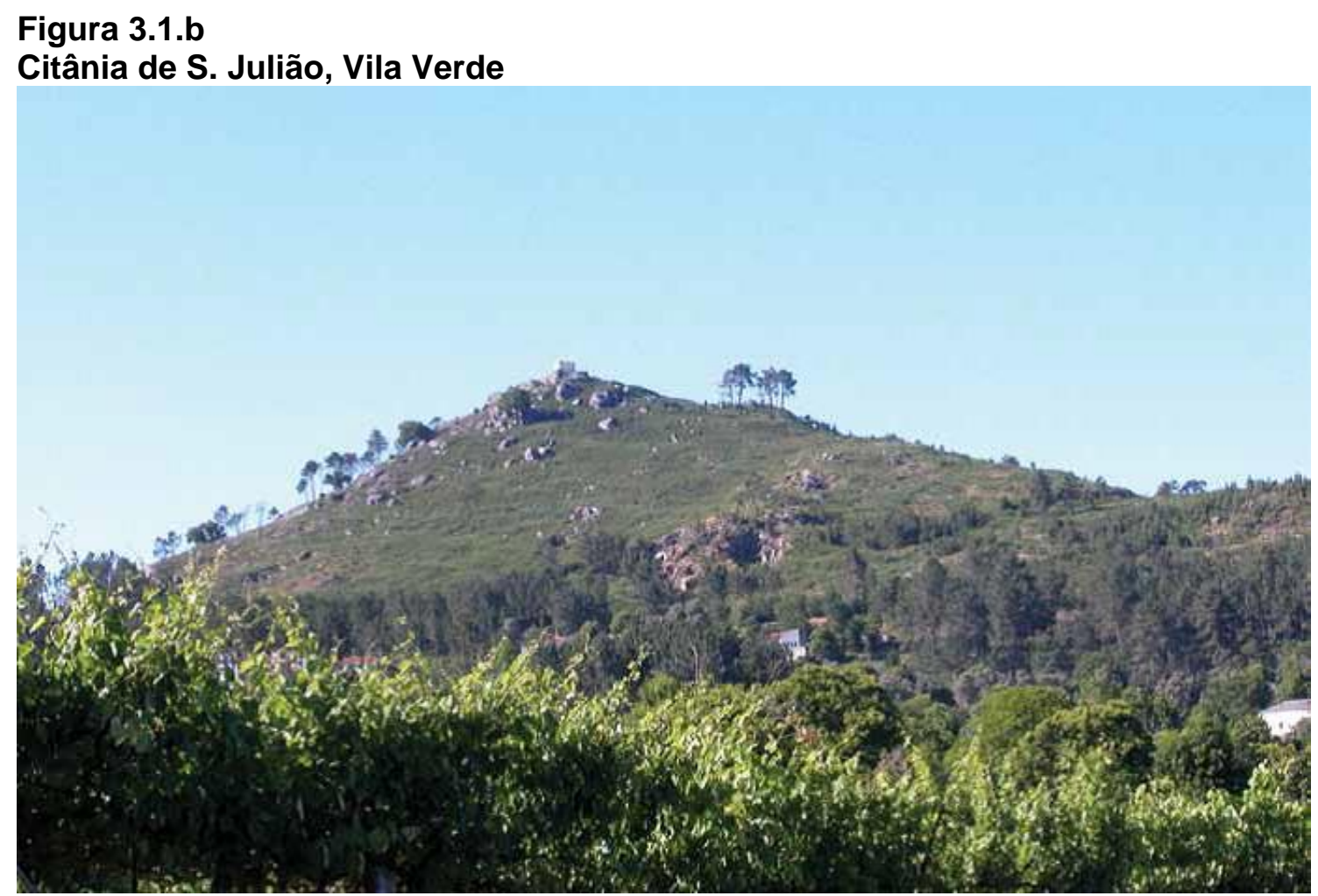

Fonte: Arquivo fotográfico da Casa de Sarmento, Universidade do Minho.

Dentro desse contexto, a área costeira das Rias Baixas, aberta aos contatos externos, apresenta-se como a mais dinâmica nesse processo de emergência da paisagem fortificada. Fenômenos como, por exemplo, o surgimento de uma arquitetura doméstica em pedra ou a importação de materiais mediterrâneos em castros costeiros e do pré-litoral apontam para uma realidade na qual o comércio de longa distância desempenhou um papel importante no direcionamento dessas comunidades à uma divisão social (MARTINS 1990; GONZÁLEZ RUIBAL et al., 2007; AYÁN VILA, 2008).

O Noroeste foi uma área muito permeável culturalmente; com influências do Atlântico e do Mediterrâneo, além de outras culturas. Esse processo se desencadeou, provavelmente, através do comércio com o Mediterrâneo controlado pelos mercadores gaditanos (NAVEIRO LÓPEZ, 1991). A partir de uma revisão desses dados disponíveis e, também, do registro arqueológico evidenciado em escavações recentes (GONZÁLEZ RUIBAL et al., 2007; AYÁN VILA, 2008), uma síntese atualizada tem sido elaborada sobre os ciclos comerciais em que as comunidades locais da costa do Noroeste Peninsular estavam envolvidas.

Com relação aos castros cantábricos, Marín Suárez (2011: 10), informa que a partir de 1000 a.C. sucederam-se uma série de acontecimentos que estão relacionados com mudanças sociais que levaram ao surgimento desses castros; "(...) y son en definitiva estas formaciones sociales que desarrollaron - y fueron determinadas por - los castros cantábricos".

Essa nova paisagem no Noroeste Peninsular, resultado de um processo longo e complexo, será composta por uma rede densa e hierarquizada de fortificações. Existe uma diversidade na arquitetura castreja; nem todos os castros são iguais e muito 
menos as formas de os habitar foram iguais ao longo do tempo (PARCERO-OUBINA; AYÁN VILA, 2016: 191).

Segundo Manuela Martins et al. (2005: 283),

Emergentes no contexto do Bronze Final, os castros tenderão a fixar-se, primeiro, nas bordaduras dos vales, depois, em relevos proeminentes das vertentes e, mais tarde, em pleno vale, ocupando aí cabeços e pequenas colinas destacadas.

Esses povoados fortificados de altura constituem um dos segmentos mais expressivos do patrimônio arqueológico do Noroeste Peninsular (LEMOS, 2009a: 122). Trata-se de uma referência fundamental da presença humana na paisagem, de natureza monumental (PARCERO-OUBINA; AYÁN VILA, 2016: 191). De acordo com Lemos (2009a: 130), a escolha dos habitats fortificados na Idade do Bronze Final foi um processo muito complexo, com diversas opções de implantação e de matriz territorial.

Esse processo de construção de uma nova paisagem social teve como vetores de desenvolvimento a nuclearização e fortificação do habitat, além da territorialização das comunidades (MARTINS, 1996; 20). Esses três vetores estão relacionados com a necessidade de demarcação das áreas de exploração econômica dessas comunidades, a garantia da posse da terra e sua apropriação efetiva (CARVALHO, 2008: 73).

Segundo Helena Carvalho (2008: 72-73),

Tanto quanto é possível verificar, a fortificação dos povoados é uma norma, representando um modo de consolidar as comunidades no quadro geográfico dos principais vales que cortam a topografia do anfiteatro do Entre-Douro-e-Minho [e sul da Galícia]. Assiste-se, deste modo, a um processo de consolidação territorial das populações, alicerçado numa sedentarização efectiva.

Dessa forma, algumas explicações sobre o surgimento desse tipo de habitat estão relacionadas com a apropriação do espaço e a intensificação da agricultura (MARTINS, 1990), como, também, ao desenvolvimento da metalurgia e do comércio à distância (PEÑA SANTOS, 1996; BETTENCOURT, 1999; CARVALHO, 2008). Essa situação pode estar relacionada com uma necessidade de exploração de recursos econômicos que pode ter levado a uma afirmação social das chefias (DINIS, 1993; MARTINS, 1996; SASTRE PRATS, 2001; CARVALHO, 2008).

Observa-se um período de transição entre o Bronze e o Ferro, e de inícios da la $^{a}$ Idade do Ferro (séculos VIII/VIla.C. até V/IV a.C.). Esse período ainda é nebuloso devido aos poucos indicadores arqueológicos. Contudo, está relacionado com momentos de retração e escasseamento do povoamento de vale (MARTINS 1990; MARTINS et al., 2005; CARVALHO, 2008). Assim, o registro arqueológico constata o abandono de povoados abertos, tanto no vale quanto na chãs montanhosas, o mesmo acontece com alguns povoados de altura (CARVALHO, 2008: 70). 
As explicações sobre essa retração e abandono de algumas áreas se baseiam em indícios de alterações climáticas e de esgotamento de solos (CARVALHO, 2008: 70-71). Essas questões poderiam explicar um provável reordenamento no território, bem como uma diversificação nos recursos alimentares, haja vista que cada castro teria seu próprio território para desenvolver uma estrutura agro-silvo-pastoril.

Apesar da escassez de dados arqueológicos desse período, para Martins et al. (2005: 283),

(...) os castros afirmam-se como forma de habitat exclusiva, num processo de materialização espacial das comunidades e dos seus termos, talvez decorrente da necessidade de controlar um conjunto de recursos críticos, que assegurassem a sua independência territorial e auto-suficiência.

O período seguinte está relacionado a uma II $^{\mathrm{a}}$ fase, equivalente ao período inicial da $I^{a}$ Idade do Ferro, que se inicia em meados do $I^{\circ}$ milênio a.C. Esse período, especialmente a partir do século II a.C., corresponde a fase plena da "Cultura Castreja", os castros constituirão a forma de habitat dominante, com os complexos sistemas defensivos, o proto-urbanismo, a ornamentação geométrica de elementos arquitetônicos, os banhos, as estátuas de guerreiros, a ourivesaria (LEMOS, 2009a: 134). Os sistemas defensivos utilizam preponderantemente a pedra e aumentam em número e visibilidade (CARVALHO, 2008).

De acordo com Parcero-Oubiña e Ayán Vila (2016: 191),

\begin{abstract}
Este feito supón varios cambios significativos: a permanencia do hábitat implica unha agricultura permanente, en interacción coa cal se constitúe un modo de vida campesiño; a fortificación amosa a xeneralización dun estado de inestabilidade que se alimentou durante o momento anterior e sobre $o$ que se constituirá aos poucos unha orde social dominada pola belixerancia ou, cando menos, pola posibilidade ou pola expectativa de que esta ocorra; e a petrificación reflicte a monumentalización, quer da comunidade, quer das casas. Campesiños, guerreiros, famílias e comunidades serán os elementos constituíntes da "cultura castrexa" e, segundo interaccionen entre eles, determinarán a súa dinámica”.
\end{abstract}

Entretanto, esses itens, tradicionalmente associados à "Cultura Castreja", principalmente a estatuária guerreira e os banhos, ocorrem em áreas bem delimitadas: nas bacias do Minho, do Lima, do Cávado e do Ave; como, também, na Asturia Transmontana, relacionada aos banhos (LEMOS, 2009a; LEMOS; CRUZ; FONTE, 2012). Essa área do Entre-Douro-e-Minho e o sul da Galícia é, por excelência, a região da chamada "cultura castreja" (CARVALHO, 2008: 72); e é caracterizada por uma grande densidade de povoados, entre os quais se reconhece a presença de grandes castros ou citânias (GONZÁLEZ RUIBAL, 2006-2007).

Será, também, na Idade do Ferro II que os castros do interior se instalarão, finalmente, nos trechos médios e inferiores dos vales. Provavelmente, a disponibilidade de uma tecnologia agrícola mais complexa, como o uso do ferro, tenha permitido uma melhor exploração dos pesados solos dos vales que apresentam 
condições ecológicas mais aptas para o cultivo permanente (SILVA 1986; MARTINS 1990; PARCERO-OUBINA; AYÁN VILA, 2016: 192).

Nos três últimos séculos do $I^{\circ}$ milênio a.C., em plena ${ } \mathrm{I}^{\mathrm{a}}$ Idade do Ferro, a área dos grandes povoados consolida-se e observa-se um bom aproveitamento da especificidade orográfica e dos corredores naturais de circulação, bem como uma elaborada rede de trocas entre o litoral e o interior (LEMOS, 2009b: 112). Esses itinerários pré-romanos, que seguem caminhos naturais de circulação, apresentam uma importância estruturadora porque atuam como rotas de longo percurso e como eixos de limites regionais que concentram esses povoados fortificados. Também devem ser considerados os principais cursos de água, entre a costa e o interior, para a efetivação do comércio de bens de prestígio importados do Mediterrâneo. Na costa constata-se uma sequência de castros, que controlam os acessos por via marítima, os locais de transbordo de mercadorias, e as zonas de produção de sal que era destinada aos povoados do interior do Minho e de Trás-os-Montes Ocidental (LEMOS, 2009b: 113).

Segundo Lemos (2009a: 183), os recursos agro-silvo-pastoris, a produção artesanal e o comércio constituíram o fundamento da prosperidade dos grandes povoados da Idade do Ferro do Noroeste de Entre-Douro e Minho e Sul da Galícia.

Observa-se um aumento no tamanho dos castros (Figura 3.1.c), estes se tornam mais monumentalizados. Também se constata a generalização de grandes muralhas (Figura 3.1.d). González Ruibal (2006-2007: 294) as subdivide em quatro tipos principais: de pedra maciça; de paramento duplo com interior preenchido com terra, pedras ou cascalho; terraplanadas; e de terra exclusivamente. 
Figura 3.1.c

Mapa de distribuição dos grandes castros do Noroeste

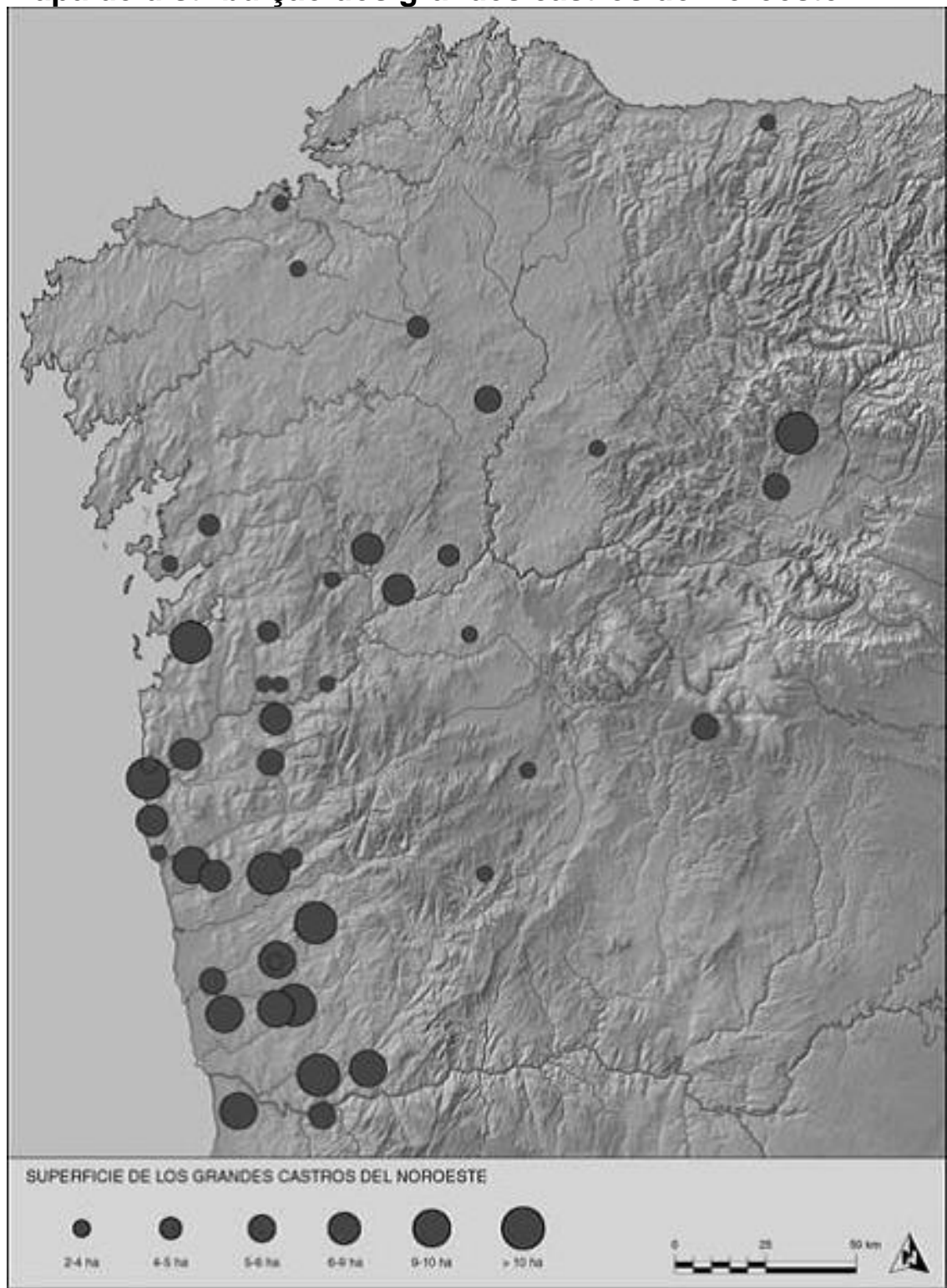

Fonte: Currás-Refojos; Sastre \& Orejas (2016: 127). 
Figura 3.1.d

Vista aérea do sistema defensivo - Citânia de Briteiros, Guimarães/Portugal

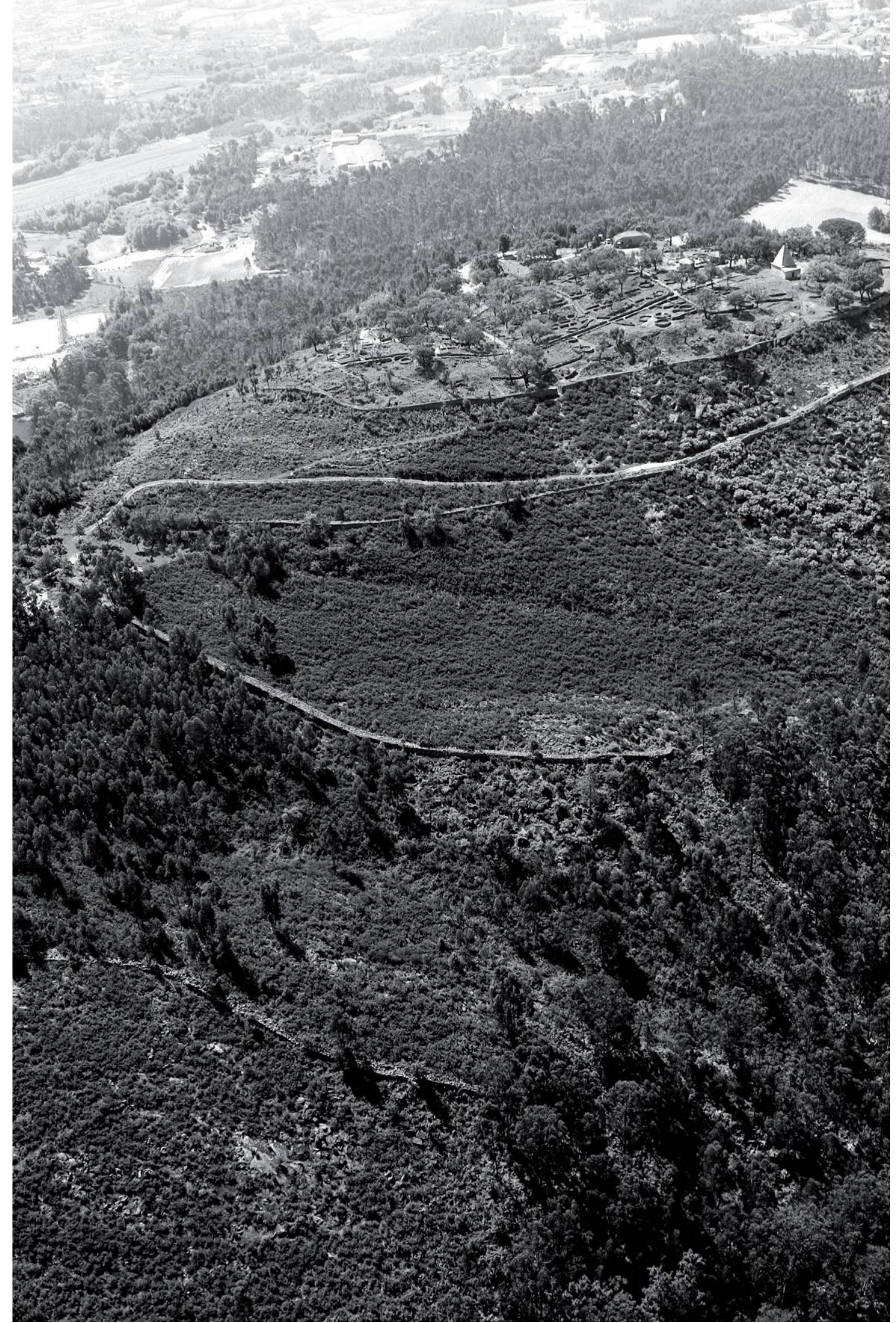

Fonte: Arquivo fotográfico da Casa de Sarmento, Universidade do Minho. 
Segundo Lemos (2009a: 158),

(...) na Ila Idade do Ferro, quer a organização dos arruamentos, quer a existência de espaços públicos e equipamentos colectivos, quer, ainda o modo como se distribuem as unidades domésticas, tudo indica um programa prévio de larga escala. (...)

Entende-se que esse programa foi dirigido pelas elites que governavam os grandes castros. Por outro lado, terá sido um movimento paralelo e coevo a outros que ocorreram na Península Ibérica, eventualmente por influência das cidades do Sul e não, forçosamente, como um reação à primeira campanha militar romana a Norte do Douro. Nesse programa, os espaços públicos e equipamentos colectivos eram lugares preferenciais de coesão comunitária, embora também de exercício de poder como garante do seu uso quotidiano e simbólico. A arquitectura doméstica, (...), passa a ser o marcador, por excelência, da diferenciação social, o sinal de prestígio e de poder.

O modelo territorial que surge na II $^{\mathrm{a}}$ Idade do Ferro produz uma nova fórmula de apropriação do espaço baseada na constituição do vale como unidade territorial e de significativa articulação espacial. Observa-se que o surgimento desses oppida ${ }^{58}$, ou seja, os grandes castros ou citânias, constituem concentrações que estão muito mais aproximadas de serem propriamente cidades, como, por exemplo, o 'Castro de San Cibrao de Las', em Ourense, na Galícia (Figura 3.1.e). Esse castro se destaca pela extensão de sua superfície, aproximadamente 10 hectares. Está situado na confluência dos rios Minho e Barbantiño, uma localização que permite um amplo domínio visual sobre o território circundante (AYÁN VILA, 2012; PARCERO-OUBINA \& AYÁN VILA, 2016).

Segundo João Fonte (2015: 54), essa “oppidização" deve ser entendida como

(...) um processo de auto-organização, consciente e intencional, das comunidades indígenas, estimulado, sobretudo na sua etapa final, por uma crescente demanda de matérias-primas pelo mundo romano (...). Não perspectivamos este processo como algo imposto por Roma, mas antes negociado e pactuado entre as comunidades indígenas e o poder romano.

\footnotetext{
58 Esse processo de "oppidização" ocorreu, basicamente, 'na parte Meridional do Noroeste Peninsular, entre os séculos II a.C. e I d.C., justamente entre o final da Idade do Ferro e inícios de época Romana' (FONTE, 2015: 51).
} 
Figura 3.1.e

Castro de San Cibrao de Las (Ourense)

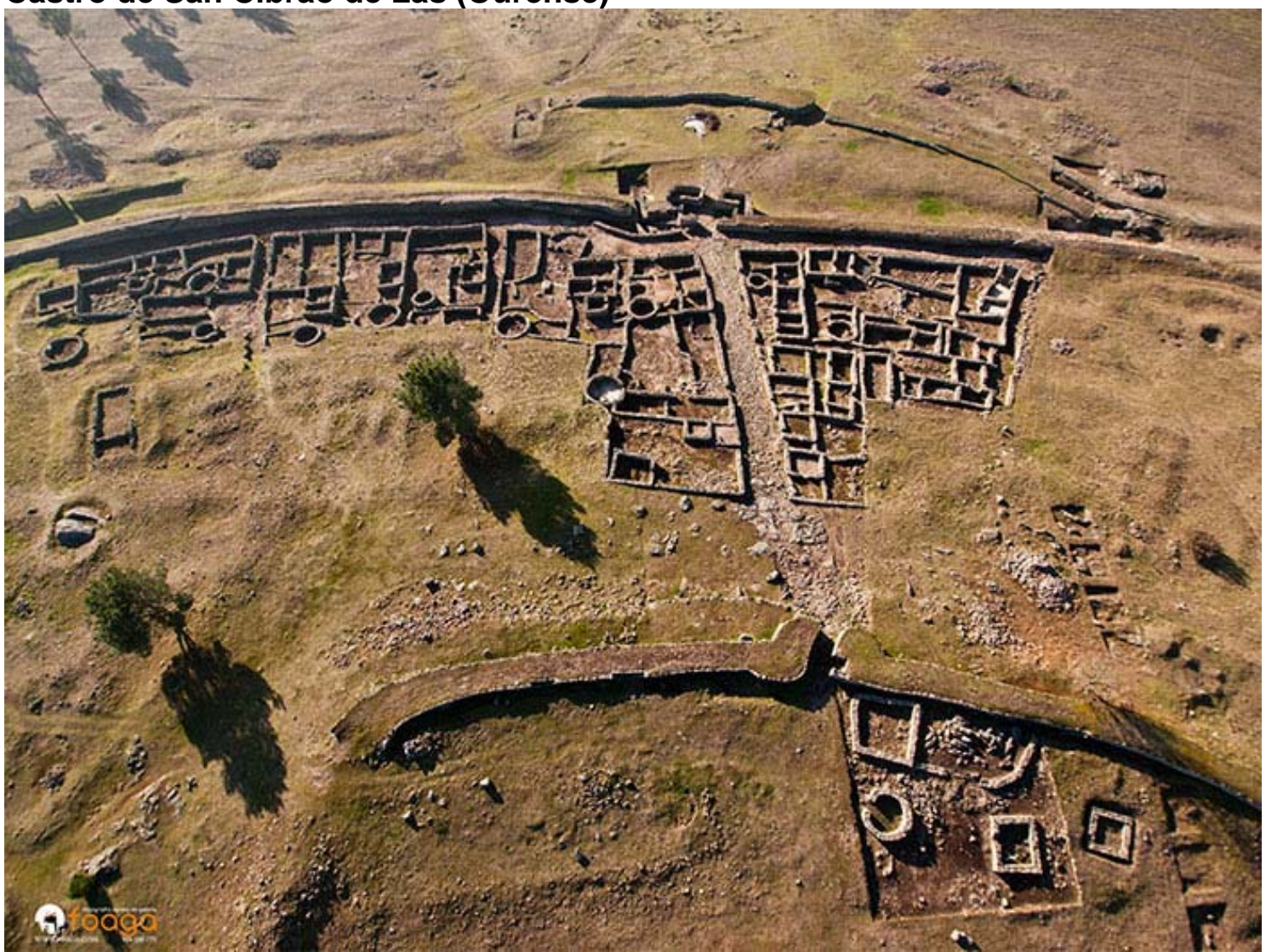

Fonte: Parque Arqueolóxico da Cultura Castrexa. Disponível em: http://pacc.es/es/o-parque/o-castro/

Uma III Fase cronológica da "Cultura Castreja" estaria incluída no quadro de conquista da Hispânia e seria marcada no âmbito do relato da expedição de Decimus lunus Brutus, em 137 ou 136 a.C. (LEMOS, 2009a).

De acordo com González Ruibal (2006-2007: 328-349), observa-se uma multiplicidade de experiências históricas particulares, em diferentes escalas, anteriormente e posteriormente a chegada dos romanos. Assim, com o desenvolvimento dos estudos regionais, deve ser considerado que existe uma diversidade regional no Noroeste Peninsular nos finais do I milênio a.C. (CARBALLOARCEO \& GONZÁLEZ-RUIBAL, 2003; CARBALLO-ARCEO \& FÁBREGASVALCARCE, 2006). Para João Fonte (2015: 53), verifica-se agora um "mosaico de grupos arqueológicos castrejos".

Além disso, o contato com o poder romano atingiu este território em cronologias diferentes e de formas diferenciadas, o que condicionou os ritmos de integração e desenvolvimento das populações pré-romanas no momento anterior à integração definitiva da Hispânia efetuada por Augusto (CARVALHO, 2008: 79).

Segundo João Fonte (2008: 11-12),

(...)a conquista romana do Noroeste Peninsular não supôs, pelo menos numa primeira fase, transformações repentinas na paisagem, pelo que muitos castros se mantiveram. Mas, desde finais do século I a. C., essa integração romana na região, levará a criação de uma nova identidade, 
embora esse processo não se desenvolva de forma simples e imediata, advertindo-se claras diferenças regionais. Só a partir do século I d. C. é que a paisagem do Noroeste começa a sofrer profundas alterações com a instalação de novos assentamentos e o abandono de muitos castros.

Momento este quando o domínio romano introduz as sociedades indígenas em fórmulas de organização e controle imperiais; "o imperio impúxose como unha superestrutura político-administrativa, operou os cambios esenciais para asegurar a hexemonía pero mantivo ao princípio as fórmulas indíxenas de xerarquía e organización social" (PARCERO-OUBINA; AYÁN VILA, 2016: 193).

\subsection{A Consolidação do Poder Romano no Noroeste}

Como pode ser observado no Capítulo 2, o domínio efetivo do Noroeste Peninsular aconteceu com a vitória do poderio militar de Roma nas Guerras CântabroÁstures. Como consequência, essa conquista implicou na organização das diversas comunidades e seus respectivos territórios, com características diversificadas, cujo estudo tem progredido significativamente nas últimas décadas, embora com ritmos diferenciados (MARTINS; CARVALHO, 2016: 220).

Provavelmente essa heterogeneidade cultural e, também, geomorfológica do Noroeste tenha influenciado o programa político-administrativo estabelecido por Augusto. Por conseguinte, Roma empreende uma nova estratégia territorial, principalmente, através do aprofundamento de conhecimentos geográficos e uma cartografia pormenorizada que foi capaz de produzir instrumentos de organização territorial, como o Orbis Pictus, a famosa carta geográfica do mundo romano executada por Marco Vipsânio Agripa e exposta no Portico Vipsania, em Roma (BENDALA GALÁN, 1989; ABAD CASAL; BENDALA GALÁN, 1997).

A pedido de Augusto, Agripa organiza o mapa administrativo da península e inclui os novos territórios conquistados. Como consequência dessa nova organização, as fronteiras da província da Lusitânia são prolongadas até o Cantábrico, passando, assim, a incluir os territórios de Asturia e Gallaecia; informação que aparece em uma passagem de Plínio quando este se refere ao Orbis Pictus de Agripa (N.H. 4, 118): "Lusitaniam cum Asturia et Gallaecia...".

De acordo com Waldmam (2013: 66),

(...) a legitimação/perpetuação do poder associa-se com modelos de representação do espaço, intrusões de ordem político-ideológica fazem inequívoca presença no afazer cartográfico. Verdadeiramente, os mapas são condicionados tanto pelo tempo e pelo espaço sob cuja tutela se desenvolvem, quanto pelo seu consorciamento com determinada hegemonia social, com a qual interagem nos termos de sua representatividade e da legitimidade que emprestam a um sistema de poder. 
Esse primeiro mapa político e administrativo do Noroeste teve, posterioriormente, seus limites ajustados. A fronteira da Lusitânia sofreu um recuo para o sul, e foi fixada no Douro, o que ocasionou a integração do Noroeste na província Citerior ou Tarraconense. E esta será dividida em Conventos Jurídicos; como relatado por Plínio em sua detalhada lista de povos até então desconhecidos.

Alguns pesquisadores afirmam que as informações de Plínio, o Velho permitem sustentar a ideia de que a Gallaecia e Asturia se integrariam, em um primeiro momento, no período da conquista de Augusto na Lusitania (entre 15/13 e 7/3 a. C.); e só posteriormente seriam transferidas à Tarraconense (OREJAS et al., 2000, 93-7; LÓPEZ BARJA, 2000, 37-38; CURRÁS-REFOJOS; SASTRE \& OREJAS, 2016: 131). Mas, Plínio (N.H. 3, 16), faz algunas críticas as medições realizadas por Agripa, principalmente ao se queixar sobre as mudanças dos limites provinciais e das distâncias dos itinerários.

Ao que tudo indica o Orbis Pictus de Agripa influenciou outras representações do orbe romano. Dentre elas, a compilação do Itinerário de Antonino e a Tabula Peutingeriana.

A Tabula Peutingeriana é uma representação gráfica "multi-continental" dos itinerários do Império Romano (CONTA, 2004). O seu desenvolvimento longitudinal apresenta uma grande deformação do mundo conhecido, por isso, a paisagem representada foi reduzida a pequenos símbolos iconográficos relacionados com a rede viária. O resultado é um compêndio gráfico de distâncias, em milhas, nas quais as vias, traçadas em linhas retas, privilegiam informações úteis aos viajantes, como, por exemplo, estalagens, tavernas, fontes de águas, refúgios de peregrinos, cadeias montanhosas, etc. O símbolo mais frequente é a representação de duas torres que ilustram um centro urbano de destaque. Os locais menos relevantes aparecem apenas com os nomes (PRONTERA, 2003).

Foi elaborada, originalmente, em um rolo de pergaminho de $0,34 \mathrm{~m}$ de altura por $6,82 \mathrm{~m}$ de largura, provavelmente no século IV; mas devido ao uso intensivo passou por diversas intervenções. No século XIX, a dividiram em 12 segmentos para sua melhor preservação ${ }^{59}$. Entretanto, o primeiro segmento (segmentum I) desapareceu, provavelmente, devido ao uso. Este segmento mostrava a região da Hispânia, constituída pela Britânia, África norte-ocidental e o estreito de Gibraltar.

O segmentum I foi reconstruído por Conradus Miller em 1916. Mas, por ter se perdido, não tem grande utilidade na localização das estações viárias (ROLDÁN HERVÁS, 1975: 108-110). A Figura 3.2.a traz a representação desse segmento que contém as capitais conventuais do Noroeste - Bracara Augusta, Lucus Augusti e Asturica Augusta. Os núcleos compostos pelas três capitais conventuais são representados por duas torres (destacadas em círculos vermelhos).

\footnotetext{
59 Para visualizar o documento completo consultar: http://www.hs-augsburg.de/ harsch/Chronologia/Lspost03/Tabula/tab_pe00.html
} 
Figura 3.2.a

Tabula Peutingeriana, Segmentum I

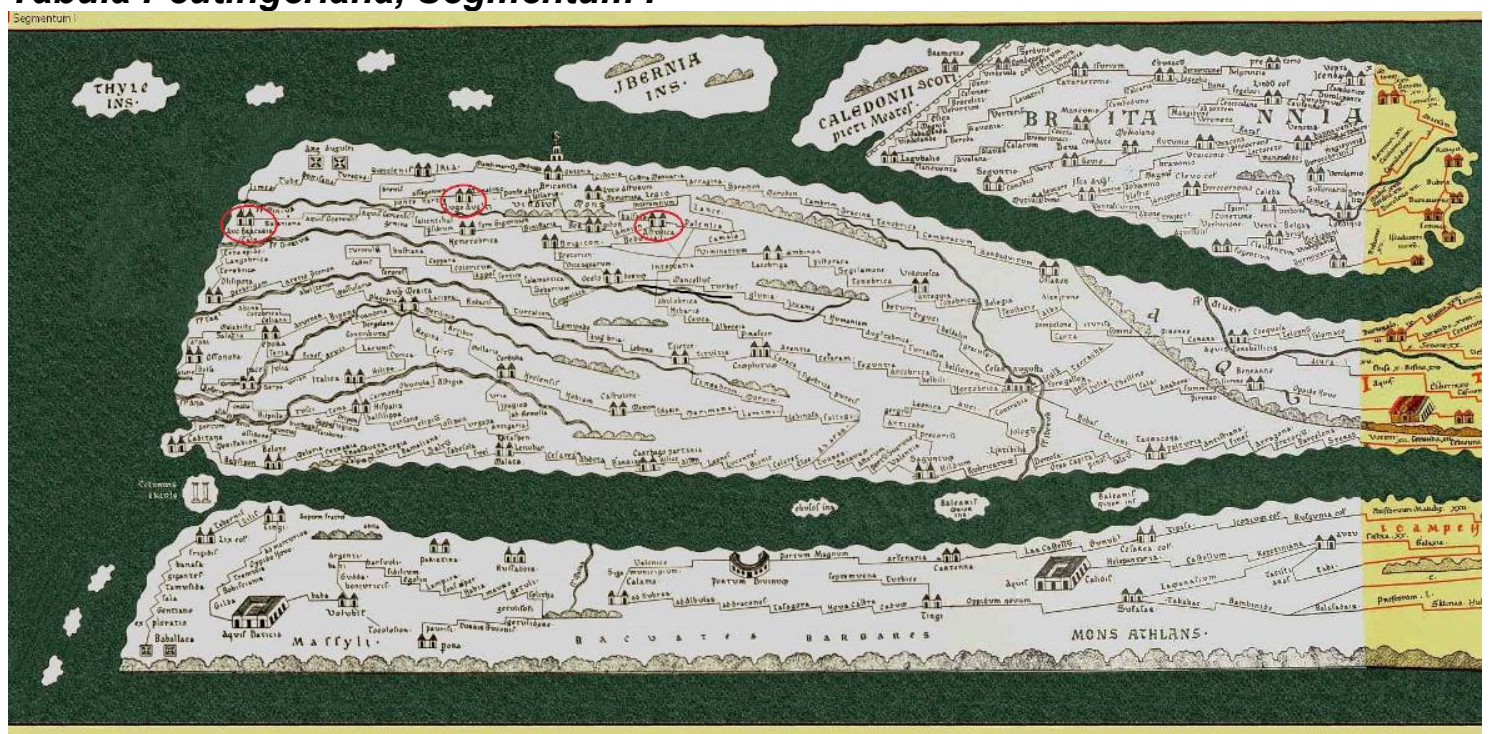

Fonte: http://www.hs-augsburg.de/ harsch/Chronologia/Lspost03/Tabula/tab_pe00.html

As principais fontes textuais que nos informam sobre as transformações relacionadas ao período de Augusto são: Estrabão, Geographia, Livro III; Pompônio Mela, Chorographia; e Plínio, Historia Naturalis. Entretanto, como já mencionado, essas informações, além de estarem condicionadas por seus interesses, são escassas e, muitas vezes, contraditórias, principalmente em relação a espacialidade das diversas etnias.

Das fontes mencionadas, a obra Geographia III de Estrabão é a que mais fornece detalhes sobre a vida e costumes dos povos pré-romanos do noroeste. Para Helena Carvalho (2008: 87), a importância dessa obra está justamente nesse inventário político do mundo por ele conhecido, que nos permite vislumbrar a distribuição espacial dos povos pré-romanos frente a expansão romana e suas consequências.

Em relação as informações sobre a estrutura sócio-política desses povos préromanos, podemos encontra-las nos relatos de Mela, Ptolomeu e Plínio, o Velho.

Estrabão, após ter citado os povos mais importantes, acrescenta: "Os outros, pequenos demais e obscuros demais, não valem a pena que o nomeemos" (III, 3, 3). Em outra passagem, ele reforça novamente sua posição: "Não me arrisco a multiplicar os nomes, recuando diante da labuta que representaria sua transcrição" (III, 3, 7). Plínio, o Velho, faz a mesma observação repetidamente, especialmente quando enumera os povos dos conventus, com nomes obscuros e bárbaros: ignobilium ac barbarae, cuja lista completa seria extremamente cansativa de fazer: citra fastidium nominentur (N.H. III, 28). Essa ideia também é retomada por Pompônio Mela a respeito dos povos cântabros (III, 28).

Apesar de suas contradições e exageros, as fontes escritas permitem um conhecimento relativo da realidade indígena com que os romanos entram em contato. É através delas que conhecemos o elenco dos populi que habitavam o Noroeste e, 
não menos importante, um esboço sobre aspectos importantes da forma de vida dessas populações, principalmente quanto à sua organização política e social.

Com relação as fontes epigráficas, essas são extremamente importantes para o conhecimento e análise de diversas questões relacionadas a organização social compreendida como pré-romana. Muitas vezes, confirmam determinadas referências apenas conhecidas através das fontes literárias, e acrescentam dados ou sugerem demarcações territoriais das populações. Informações sobre os primeiros contatos entre Roma e os povos recém conquistados também podem ser obtidas nas tabulae de hospitalidade.

Sobre os aspectos geomorfológicos, esses autores apresentam um conhecimento mais preciso sobre a costa do que com o interior. As informações fornecidas são sobre as desembocaduras dos rios Douro, Lima e Minho, as Rias Baixas, o cabo Finisterra e a ria múltipla Coruña-Betanzos-Ares-Ferrol (NAVEIRO LÓPEZ, 1991).

O conjunto de informações contidas em autores clássicos como Plínio, o Velho, Estrabão e Ptolomeu, juntamente com os dados epigráficos e das tabulae de hospitalidade, permitem conhecer o nome de diversas civitates citadas. Plinio, o Velho (N.H. III), por exemplo, nos fornece dados sobre os populi e os capita libera.

Para Helena Carvalho (2008: 82), em relação a organização desses populus e civitas, a principal dúvida está na seguinte problemática: estes teriam como base os agrupamentos pré-romanos ou seriam realidades meramente administrativas, criações artificiais, impostas pelo poder romano? Segundo Estrabão, em seu Livro III, os romanos seriam os responsáveis por levar a política, ou seja, a civilização, à esses povos.

Não há consenso sobre esse assunto. Mas com base nas informações de Plínio, - Velho, Estrabão e Ptolomeu, juntamente com fontes epigráficas, autores como Naveiro López (1991), Rodríguez Colmenero (1995, 1996), Tranoy (1981), Silva (1986) e Alarcão (1988; 1992; 1995-96), tentaram estabelecer uma cartografia dessas civitates.

As Figuras 3.2.b e 3.2.c, apresentam a reconstrução do Noroeste elaborada por Naveiro López (1991), a partir dos relatos de Estrabão, Mela, Plínio, o Velho e Ptolomeu. A Figura 3.2.d, apresenta a proposta elaborada por Rodríguez Colmenero para os Populi e Civitates da Gallaecia. E a Figura 3.2.e, apresenta a representação elaborada por Tranoy (1981). 
Figuras 3.2.b

Representação dos relatos de Estrabão, Mela e Plínio, o Velho

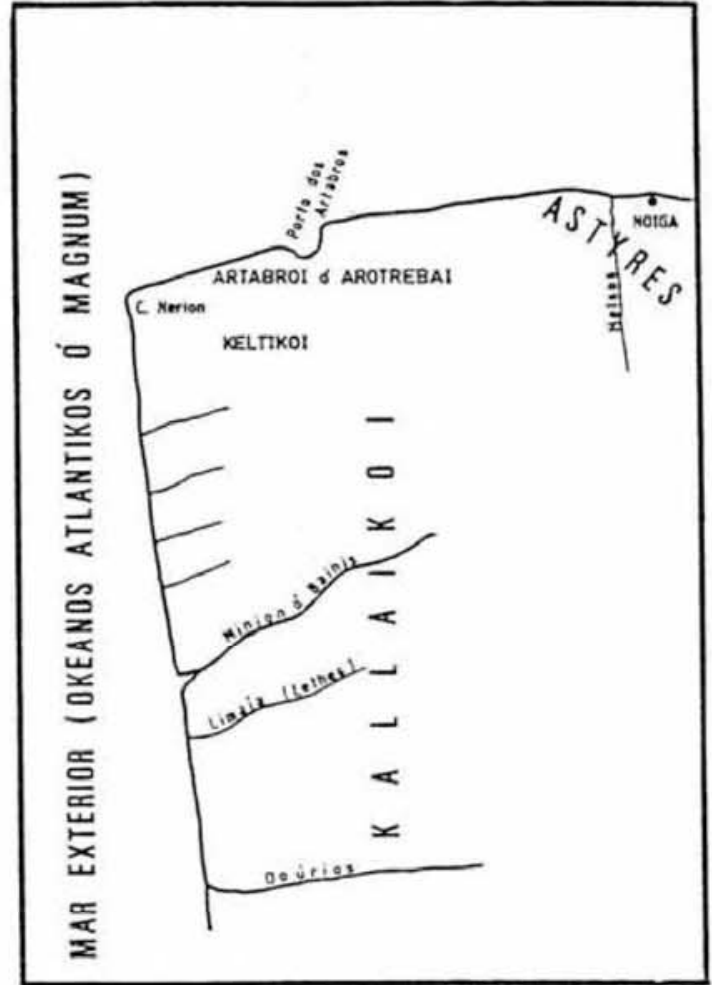

ESTRABON

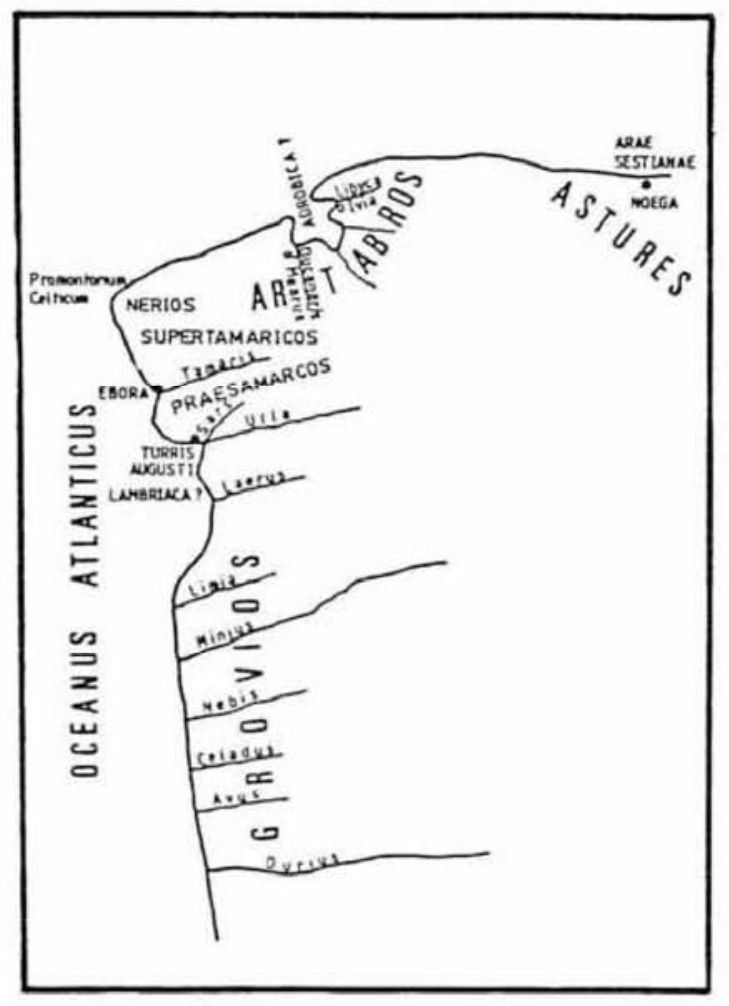

MELA

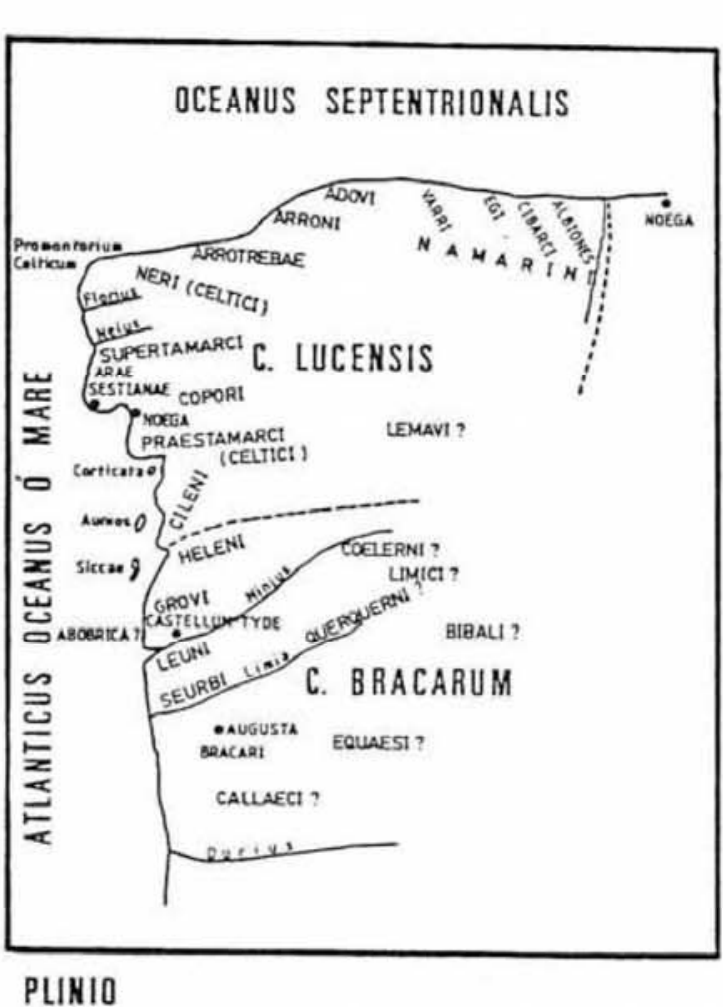

PLINIO

Fonte: Naveiro López (1991: 122) 
Figuras 3.2.c

Representação dos relatos de Ptolomeu

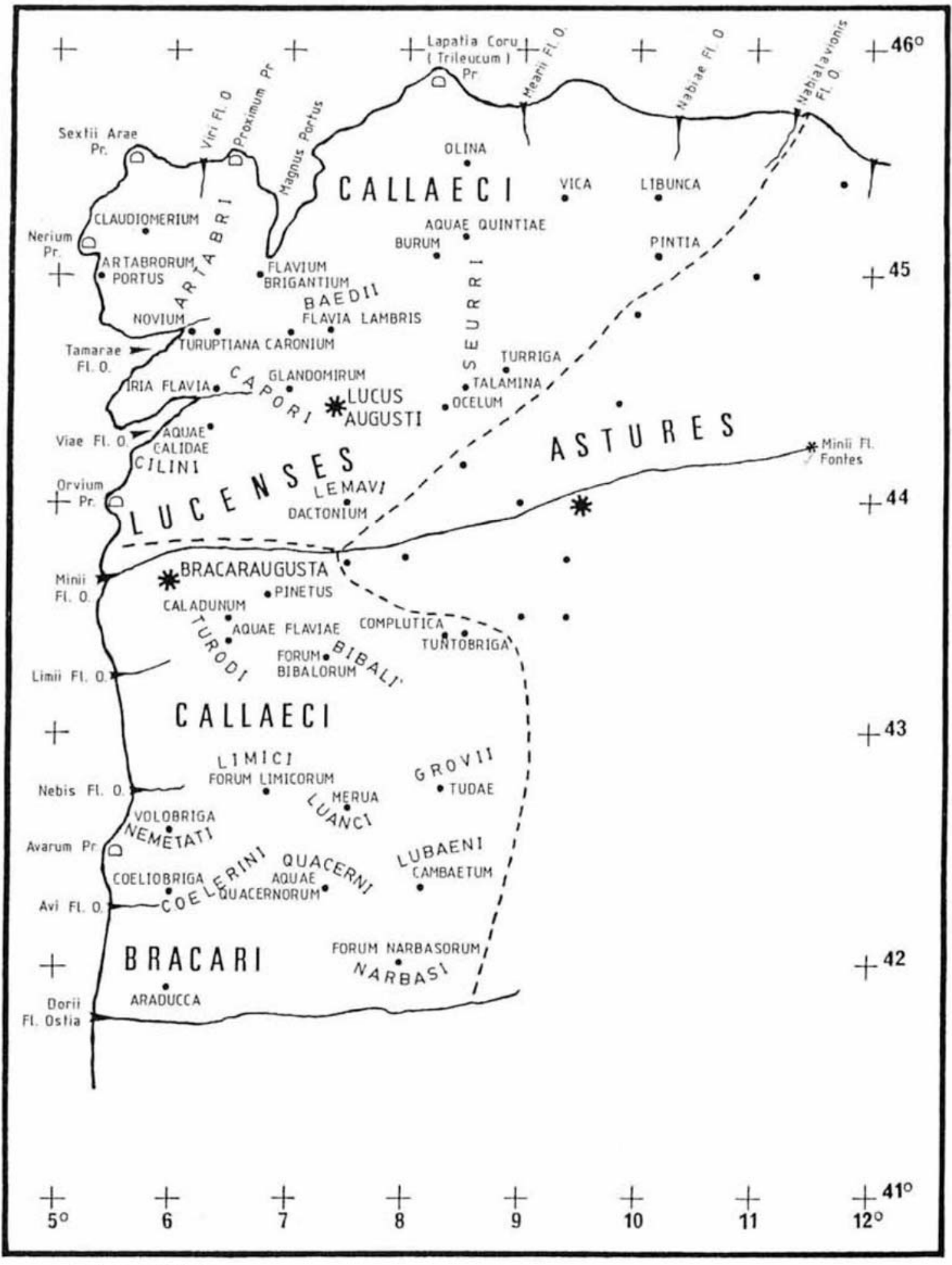

PTO L OMEO

Fonte: Naveiro López (1991: 123) 
Figura 3.2.d

Populi e Civitates da Gallaecia

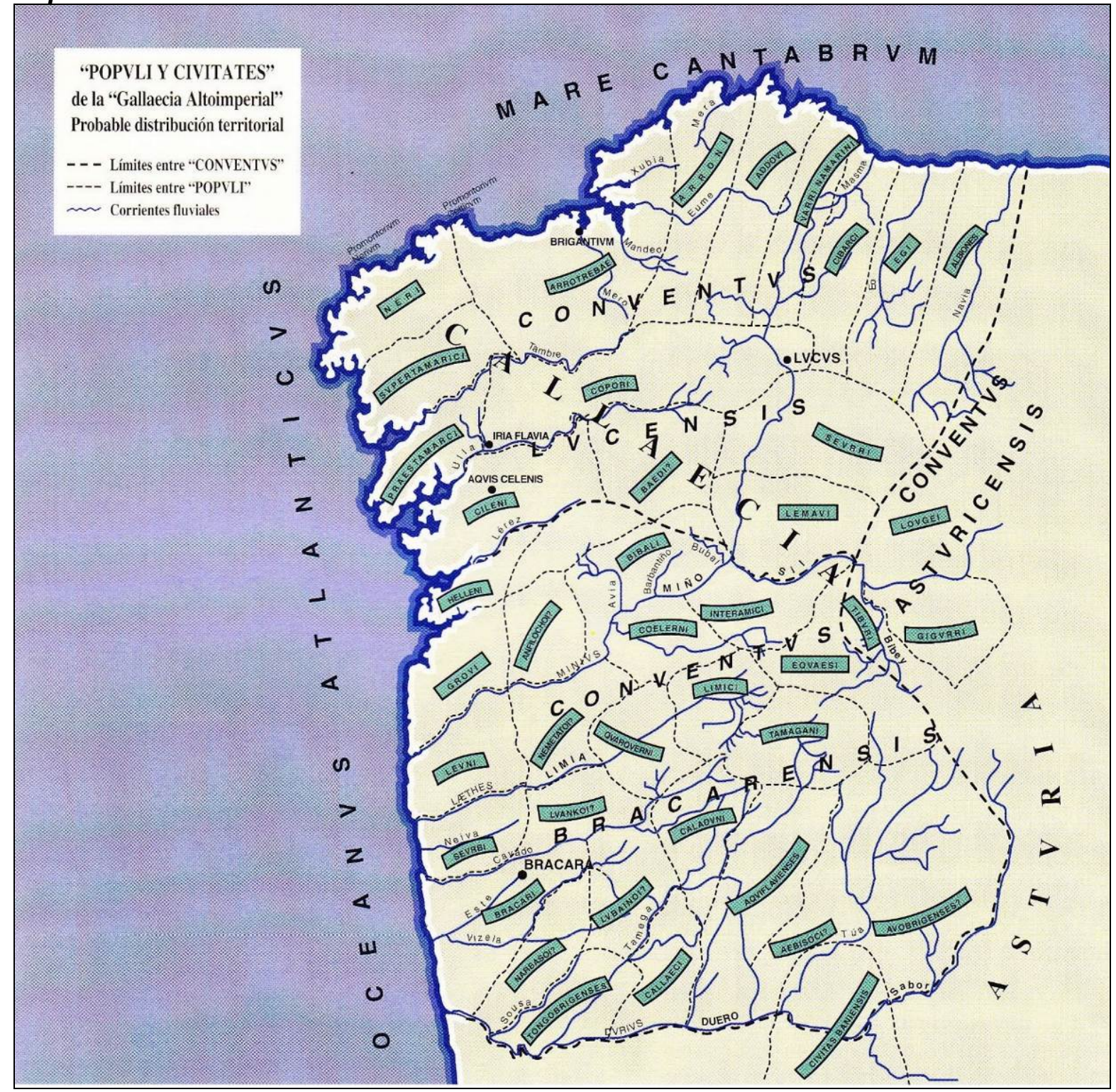

Fonte: Rodríguez Colmenero et al. (1995: 20). 
Figura 3.2.e

\section{Geografia e povoamento antigo do Noroeste Peninsular}

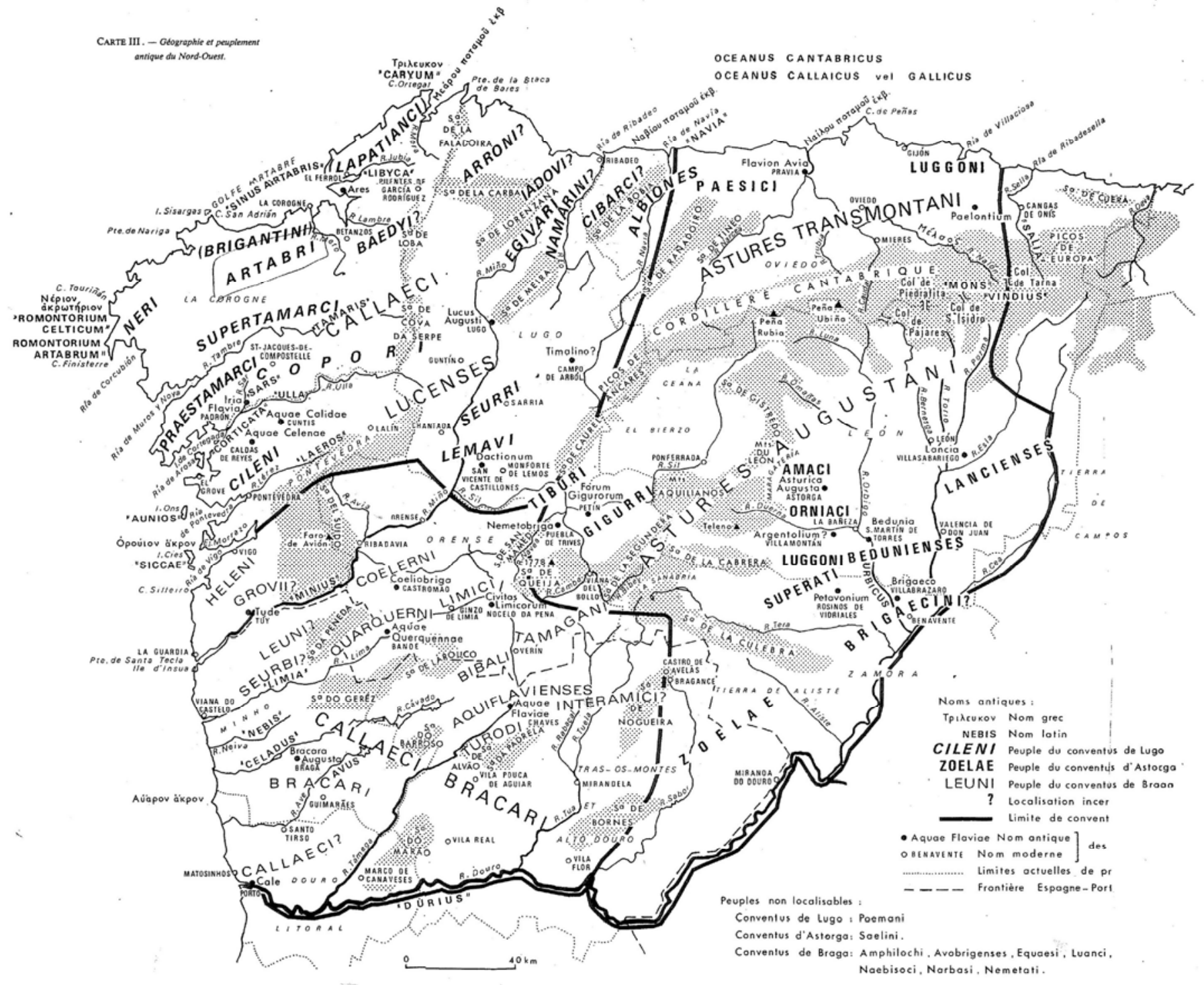

Fonte: Tranoy (1981: Carte III). 
Estamos de acordo com Helena Carvalho (2008: 95), sobre o fato de ser impossível tentar coincidir, de maneira exata, as formas de organização conhecidas através das fontes literárias com a geografia anterior à sua presença na região.

Para Salinas de Frías (2007: 8),

(...) las discusiones acerca de los límites geográficos de los distintos pueblos prerromanos no pueden ser resueltas mucho más allá de lo que lo han sido hasta ahora. Aparte de las contradiciones, a veces insolubles, existentes en las fuentes literarias, hai que tener en cuenta que la situación étnica y política en la Península antes de la conquista romana era muy fluida y que los límites dichos pueblos no pueden ser entendidos como fronteras de los estados actuales, que pertenecen a un tipo de sociedad completamente diferente. Por otra parte, la vieja ilusión de correlacionar etnia, lengua y cultura ha entrado definitivamente en crisis desde todas las perspectivas. Pueblos étnicamente distintos pueden compartir lengua $y$ cultura y, a la inversa, pueblos de la misma etnia pueden tener culturas diferentes.

Na nossa opinião, o debate deve ser colocado em um outro plano, com base na análise da natureza e gênese do processo de urbanização no Noroeste Peninsular a partir da perspectiva do estudo das paisagens. Nosso objetivo é examinar uma das principais novidades que será introduzida nas paisagens de época romana e que se materializa pela primeira vez no Noroeste Peninsular: a lógica da rede viária, baseada em nós e linhas. E para isso é preciso, primeiramente, analisar algumas mudanças que foram produzidas durante o governo de Augusto, haja vista que ele foi o responsável pela implantação de uma política administrativa fundamental para a integração e exploração do Noroeste Peninsular no Império Romano.

\subsection{A Política Urbana de Augusto}

Durante a conquista e integração da Península Ibérica ao Império Romano, "existia uma considerável fragmentação, étnica e política, nas populações do Ocidente hispânico, com expressões culturais bem distintas" (FABIÃO 2012: 28). O conceito de identidades discrepantes (MATTINGLY, 1997), pode ser utilizado para explicar as diferentes respostas e reações dos povos locais em relação à cultura romana. Dessa forma, "as sociedades coloniais poderiam, conforme o contexto, demonstrar similaridades ou discordâncias culturais em relação ao modelo imperial romano" (MATTINGLY, 2011: 213).

As mudanças produzidas durante o governo de Augusto fazem parte de um momento fundamental para o conhecimento sobre a integração definitiva do Noroeste Peninsular, uma vez que as transformações são resultado imediato da conquista. Dessa forma, com Augusto se inicia uma nova etapa no processo de implantação romana na região. 
De acordo com Dopico Cainzos (2016: 87),

En la época a la que nos estamos refiriendo, más que hablar de Estado en abstracto, debemos referirnos a la profunda intervención de Augusto en los asuntos de gobierno, sin precedentes en la historia de Roma que solo se pueden explicar por la excepcional confluencia de varios factores relevantes.

Entretanto, a obra do governo de Augusto não era devidamente reconhecida, principalmente, devido a escassez de evidências materiais. De acordo com uma passagem de Tranoy (1981: 257):

A la fin du lle siècle, le Nord-Ouest fait désormais partie intégrante des provinces ibériques et du monde romain. Dans le processus de réorganisation qui a abouti à ce résultat, l' empereur Vespasien et ses fils jouèrent un rôle fondamental. Sous leur règne, se fixèrent les cadres administratifs et financiers tandis que les villes créées par Auguste ou nées au cours du ler siècle reçurent une promotion municipale en rapport avec leur fonction de capitale de 'conventus' our leur rayonnement régional. Si le Nord-ouest forme au début de l' Empire une région encore difficile, sous surveillance militaire constante, les nouvelles routes, en particulier la 'via nova' des Flaviens, en font une province accessible qui devient en même temps une source de richesse pour l' Empire.

Neste trecho, verifica-se que Augusto aparece como conquistador do território. Contudo, sua obra de reorganização territorial não parece ter uma consequência mais profunda nas populações pré-romanas. Já com relação a Vespasiano, este aparece como o impulsionador de transformações importantes que afetam a administração, além de uma melhor integração econômica e espacial do território.

Entretanto, a partir de dois documentos encontrados, a obra de reorganização administrativa de Augusto na Hispânia foi revista. Esses documentos, relacionados a pactos de hospitalidade são: a "Tabula Paemeiobrigensis" e a "Tabula Lougeiorum".

O "Édito del Bierzo" ou "Tabula Paemeiobrigensis" (Figura 3.3.a), foi encontrada em 1999 por um particular que a entregou ao Museu de León, na Espanha. Este documento é importante por se referir à província transduriana (Transdurianae provinciae), desconhecida até o achado dessa placa de bronze. Após uma breve introdução que menciona os poderes do imperador, apresenta dois editos de Augusto sobre a boa disposição mostrada por uma comunidade indígena, os castellani Paemeiobrigenses. O texto, além de mencionar os castellani Paemeiobrigenses (castellanos Paemeiobrigenses), também faz menção a gens Susarri (gente Susarrorvm), e contém trechos sobre à questão da posse de terra e de seus limites. A parte final, traz o local onde se emitiu o edito, Narbo Martius, e a datação com a indicação do ano exato, os dias e o mês (14 e 15 de fevereiro de 15 a.C.). Isso o insere como o documento mais antigo do Noroeste Peninsular. (ALFÖLDY, 2001; DOPICO CAÍNZOS, 2006, 2009). 
Figura 3.3.a

"Tabula Paemeiobrigensis"

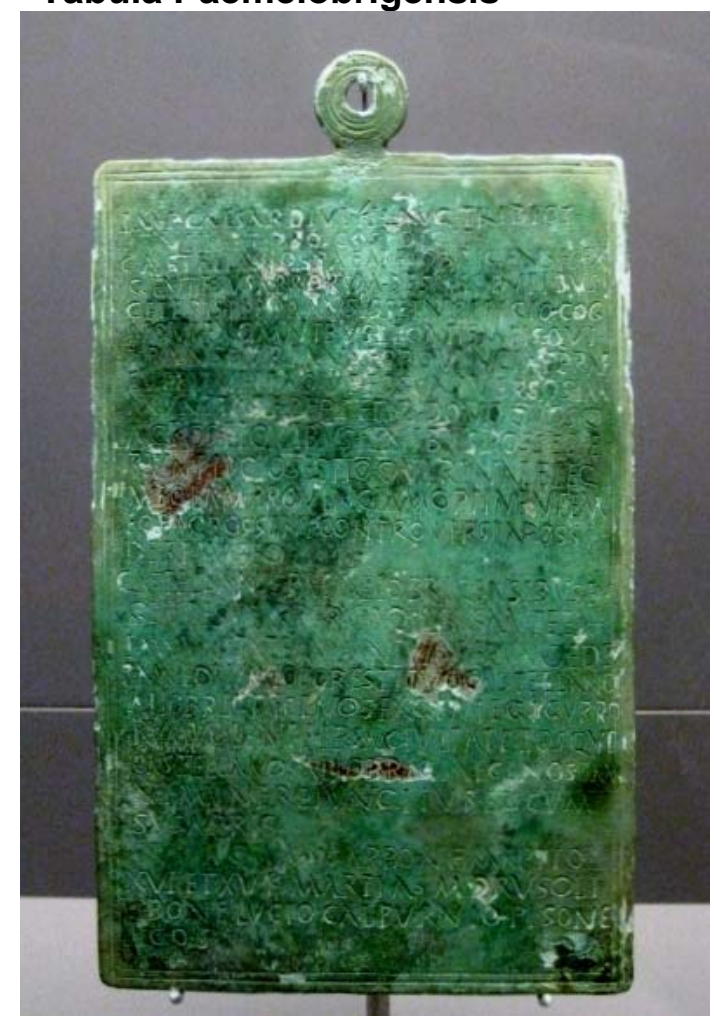

Fonte: E. C. C. da Silva (Museu do Alto Bierzo de Bembibre, jul.2013)

A "2 2 Tabula dos Lougei" ou "Tabula Lougeiorum" (Figura 3.3.b), foi recuperada em 1984 graças a um procedimento judicial que impediu sua exportação irregular à Inglaterra. Um morador de A Coruña, na Espanha, durante suas excursões pelas montanhas galaico-leonesas a encontrou, se desconhece em quais circunstâncias, e acabou por oferecê-la ao Museu Britânico de Londres. Os responsáveis por essa instituição, primeiramente, comunicaram o ocorrido a pesquisadores espanhóis e, posteriormente, às autoridades competentes da Junta de Galícia sobre a natureza do objeto oferecido para aquisição.

Trata-se de uma segunda tabula relacionada ao mesmo grupo sócio-político dos Lougei; dessa vez denominado expressamente civitas e atribuída a mesma área geográfica. Quanto ao conteúdo, diz respeito a um pacto de hospitalidade entre Illote Asinio Galo, um cidadão romano, e uma comunidade indígena, a civitas Lougeiorum, realizado no ano I d.C. (RODRÍGUEZ COLMENERO, 1997; PEREIRA-MENAUT, 1984; DOPICO CAÍNZOS, 2006, 2009). 


\section{Figura 3.3.b}

"Tabula Lougeiorum"

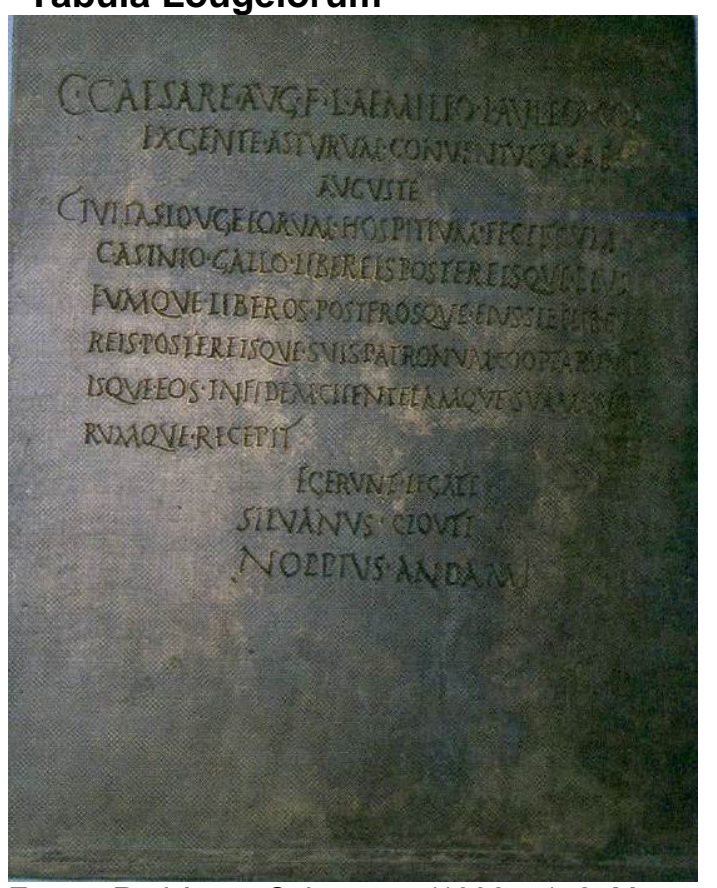

Fonte: Rodríguez Colmenero (1996a: 172, Museu de San Antón, A Coruña)

Esses dois documentos foram elaborados logo após a finalização da conquista, oficialmente dada por concluída em 19 a. C. Dessa forma, ambos pertencem ao período do imperador Augusto. Outro fator importante está relacionado a sua natureza; trata-se de um documento epigráfico. Portanto, é um texto transmitido diretamente.

Dessa forma, trata-se da transmissão direta de um ato do imperador e não de uma interpretação de um autor antigo (DOPICO CAÍNZOS, 2009); se o edito é um ato oficial, o pacto realizado na "Tabula Lougeiorum" não pode ser analisado como uma relação privada já que $C$. Asinio Galo desempenhava um cargo na administração provincial romana, ou seja, representava o imperador (BOSWORTH, 1972: 441).

Para Dopico Caínzos (2009: 36), esse é um exemplo do que poderia ser denominado de "agentes oficiais da mudança", os que fazem parte do sistema de poder romano. Ou seja, transformações que são consequência de uma ação direta de Roma, induzidas "de cima", a partir de leis ou normas que emanam do poder imperial ou de pessoas que atuam sob o seu mandato.

Portanto, são dois documentos fundamentais para o entendimento sobre as mudanças no Noroeste Peninsular como consequência direta da conquista e por iniciativa imperial. Em um primeiro momento, verifica-se que esses documentos informam sobre os novos quadros administrativos e, assim, demonstram a perda de autonomia das comunidades indígenas, agora integradas ao império romano. Por exemplo, fazem menção as civitates, como a dos Lougei na "Tabula Lougeiorum". São seguidas pelas entidades administrativas maiores, os conventus - Ara Augusta -, no mesmo documento, e, posteriormente, pelas províncias, como a Transduriana, que aparece na "Tabula Paemeiobrigensis". 
De acordo com Dopico Caínzos (2009: 36), essa aparente simplicidade esconde a enorme complexidade da administração romana, "que se manifesta no seu proceso de creación de novas entidades e na reorganização das comunidades indíxenas preexistentes".

Em um segundo momento, observa-se que as duas tabulae demonstram que as transformações ultrapassam os aspectos administrativos. Podem ser verificadas: as mudanças no território, com a fixação de novos limites para as comunidades, além de uma articulação diferente delas; a fundação de cidades que exemplificam os modos de vida romanos; as mudanças econômicas relacionadas a fiscalização e ao regime de propriedade de terra; a elaboração de normas jurídicas que foram impostas as populações indígenas; a criação de identidades coletivas com novos elementos ideológicos de coesão; a utilização das elites indígenas como instrumentos de integração no império e a obtenção de alianças através de pactos de amizade com representantes do poder romano (DOPICO CAÍNZOS, 2006, 2009).

Segundo Le Roux (2014: 36), Augusto "inventou" uma nova política administrativa nas relações entre Roma e as populações das províncias. Os fundamentos eram a ausência de autonomia: uma província não era nada diferente e nem mais que a lista alfabética das comunidades que a compunham (...).

Já foi comentado anteriormente, no capítulo 1, que a atuação de Roma na nova organização territorial e administrativa não foi uniforme, nem a resposta ibérica ante a sua presença. As medidas efetuadas por Augusto não se deram num vazio mas num "mosaico de identidades", com atenção a essas realidades locais. De acordo com Dopico Caínzos (2006: 430), "La conquista forma parte de una política más amplia, más ambiciosa, y más compleja, obedece a una cuidadosa planificación y no responde a la causalidad."

Essas medidas provocaram uma intervenção direta sobre esses territórios e populações, o que ocasionou o estabelecimento de um sistema administrativo uniforme para todo o Noroeste Peninsular, com diferenças a escala local e regional devido aos interesses específicos do poder imperial. Para Fernández Ochoa e Morillo Cerdán (2015: 184),

El fenómeno de la romanización del Norte no fue, por lo tanto, un fenómeno aislado y peculiar dentro del conjunto de Hispania, sino equiparable, dentro de sus propios parámetros, al de cualquier otra región peninsular. En este sentido, los territorios septentrionales no serían los menos romanizados, sino romanizados de modo diferente.

É importante enfatizar o envolvimento direto de Augusto em assuntos administrativos, pois trata-se de algo inovador. Isso só foi possível devido a transformação no sistema de poder romano que permitiu a Augusto realizar intervenções que anteriormente não teriam sido possíveis.

Como Princeps, Augusto tem em suas mãos uma autoridade que o permite implementar um programa próprio de governo, baseado em seu conceito de Império. Diferentemente do período republicano, com seus mecanismos de controles e interesses, agora observa-se a possibilidade de adoção de medidas administrativas, políticas e/ou econômicas sem a necessidade do controle de outras magistraturas. 
Segundo Helena Carvalho (2008: 84):

Com a instauração do principado, Augusto passa a deter um 'imperium' sobre uma ampla 'provincia', englobando grande parte das áreas conquistadas. Impunha-se, então, transformar Roma numa capital imperial e os restantes territórios em verdadeiras províncias. A conquista definitiva da Hispânia em que o próprio Augusto se envolveu directamente será, por isso, mais um trunfo do seu 'imperium' e a consignação de um modelo de organização administrativa do território.

Trata-se, portanto, de um período de mudança e transformação na própria Roma, no qual está a frente do Estado romano alguém que não compartilha o poder com outras instituições e que o detém por um tempo prolongado, ao contrário do que acontecia na anualidade das magistraturas republicanas. Isso permitiu que Augusto realizasse uma transformação das estruturas essenciais do Estado romano, praticamente em todos os aspectos internos e externos. O imperador simbolizava 0 império.

Segundo Bendala Galán (1998: 129),

Las consecuencias fueron enormes para Roma, orientada en su singladura histórica por una verdadera revolución del rumbo social y político, y para el conjunto del Imperio. Para Hispania (...) los efectos de la reorientación sociopolítica de Roma fueron decisivos.

Dessa forma, Augusto se aproveita desse contexto para empreender, de maneira pragmática, um ambicioso programa de reformas. Entretanto, devemos cogitar que a criação de um poder pessoal, com o abandono gradual das formas republicanas, além do controle de seus órgãos institucionais, faz parte de um processo longo e complexo, de longa duração.

A anexação do território das populações do Noroeste Peninsular se tornaria um elemento modificador significativo de suas estruturas organizacionais, contribuindo para o processo de reorganização administrativa e territorial, assim como, na manutenção do sistema sócio-econômico romano e de novas formas ideológicas (FORNI, 1976: 52-56). O império romano empreendeu a integração de sociedades humanas no tempo e no espaço.

Portanto, quando se analisa as mudanças no Império não podemos deixar de analisar a dupla faceta que vincula os interesses públicos - estender e consolidar o domínio romano - com o interesse pessoal - reforçar o poder de um determinado indivíduo. De acordo com Dopico Caínzos (2016: 87):

A partir del 23 a.C. cuando Augusto ya tiene conformados sus poderes con esa mezcla de respeto aparente a la legalidad republicana y de innovación, y dispone del 'imperium proconsulare maius' que se extiende sobre todas las provincias del imperio, puede ejercer su autoridad de manera totalmente diferente a lo hasta ahora conocido. 
Uma vez conquistado o território, quais são as mudanças fundamentais para integrá-lo ao império e, ao mesmo tempo, exercer o seu domínio? A conquista definitiva da Hispânia deve ser entendida como parte de uma ideia de criação de um conjunto territorial coerente e homogêneo do qual o Noroeste faz parte. A ordem imperial deve ser entendida dentro de um espaço consensual.

As medidas adotadas por Augusto objetivam, assim, uma articulação e organização de todo esse sistema imperial. Essas medidas podem ser verificadas tanto no Édito do Bierzo (15 a.C.) (SÁNCHEZ-PALENCIA; MANGAS, 2000), quanto na Tabula Lougeiorum (1 d.C.) (RODRÍGUEZ COLMENERO, 1996; DOPICO CAÍNZOS, 2006, 2009) que apontam uma implementação precoce do sistema das civitates no conventus Asturum, ainda em época de Augusto.

Portanto, a partir de agora não basta apenas a exploração dos territórios conquistados, mas de se desenvolver mecanismos administrativos eficazes. Para Santos Yanguas (2014: 163),

El objetivo de los romanos tras la finalización de las guerras asturcántabras se centraría en la articulación del territorio para incluirlo en el marco de la administración romana; se trataba de organizar dicho suelo, de acuerdo con los parámetros aplicables a las demás provincias romanas, a 3 niveles: provincial, conventual y municipal.

Será dentro dessa perspectiva que Augusto empreenderá uma política administrativa na Hispânia, a qual modificará de maneira profunda as estruturas existentes. $E$ uma de suas ações foi integrar as comunidades pré-romanas nos níveis inferiores da administração, levando-as a assumirem algumas funções básicas dentro dessa nova organização estatal. Para Pérez Losada (2002: 25), os Populi funcionam como ponto de partida, readaptando-se, física e socialmente, a nova estrutura administrativa da Civitas.

Trata-se de lealdade recíproca. Augusto fez com que as civitates realizassem-se tarefas importantes e práticas como, por exemplo, o censo, o controle de impostos e das novas redes viárias, que articulariam todo o território, garantindo, dessa forma, o funcionamento eficaz desse sistema (DOPICO CAÍNZOS, 2009).

Além disso, Augusto empreendeu o processo de fundações de novas colônias, de direito romano ou latino, que foi acompanhado de uma urbanização dos novos territórios conquistados. Mas uma das principais ações de Augusto foi efetuar a subdivisão do império em províncias o que implica em outros níveis hierárquicos de organização, entre os quais se destacam os Conventus luridici e as Civitates. Nesse cenário, os Conventus luridici serão convertidos em entidades territoriais intermediárias entre as Civitates e as províncias (Figura 3.3.c).

Apesar da historiografia tradicional ter considerado, por muito tempo, que os conventos correspondiam a uma criação de época Flávia (TRANOY 1981; ALARCÃO 2002); atualmente é consenso sua fundação na época de Augusto. 
Figura 3.3.c

Limites dos Conventos Jurídicos da Hispânia com a divisão em províncias e conventos

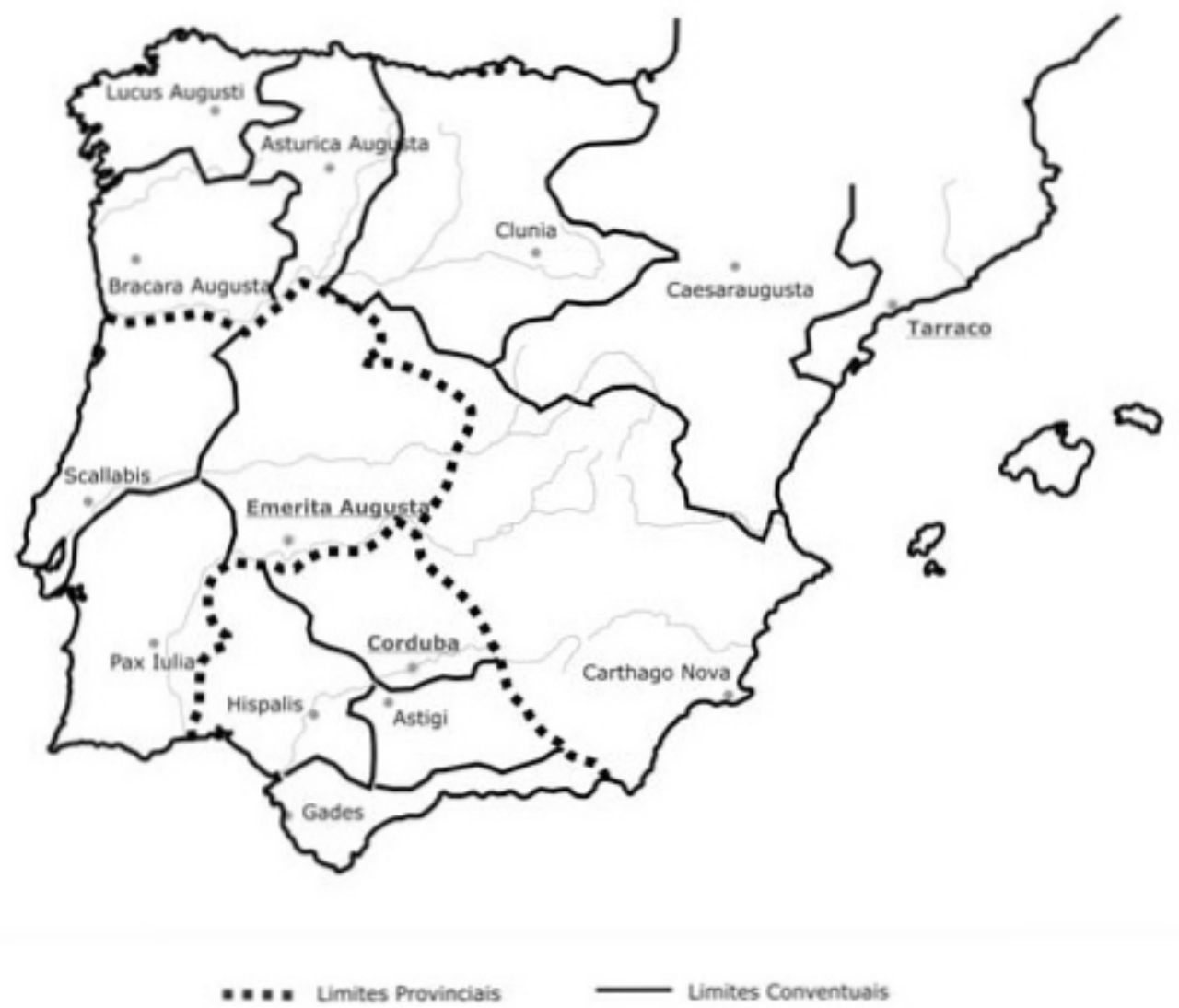

Fonte: Carvalho (2008: 65).

Para Dopico Caínzos (2016: 90),

Las transformaciones y el trabajo de creación fueron aquí, mayores, porque no había precedentes a partir de los cuales se pudieran estructurar, a diferencia de lo que habíamos visto en el caso de las civitates y provincias. De nuevo hay que decidir los límites, adscribir los pueblos a cada uno de ellos $y$, sobre todo, elegir las ciudades que actuarán como centros conventuales. Aquí es en donde vemos hasta dónde llega la planificación de todos los elementos territoriales y administrativos que permiten el funcionamiento de los conventus y, sobre todo, encontramos la razón de ser de las fundaciones urbanas del Noroeste.

Como o Noroeste Peninsular não era um meio urbanizado, as três cidades que serão sedes conventuais são fundadas ex novo: Bracara Augusta, Lucus Augusti e Asturica Augusta. Portanto, diferentemente das anteriores, não são colônias de povoamento nem o resultado de transformação de assentamentos indígenas anteriores. São cidades fundadas por Augusto com funções administrativas. Para Dopico Cainzos (2016: 87) "estamos ante ciudades que han sido fundadas por el Estado romano con una clara funcionalidad política". 
A finalidade dos conventus ${ }^{60}$ era aproximar o poder das comunidades indígenas através da criação de sedes que facilitassem a realização do circuito anual do governador. Não existia a possibilidade de que essas ações de governo ocorressem em sedes que não fossem urbanas, ou em outro tipo de entidade menor.

Segundo Dopico Caínzos (2009: 37),

“(...) nos 'conventus' que aplican as leis son, ou ben o gobernador provincial en persoa, ou ben aquela persoa en quen delegue, en ambos os dous casos os representantes do Estado romano, que, a través das súas instituicións é quen o designa para esse cargo, o lexitima e, polo tanto, lle concede os poderes necesarios para desempeñar tales funcións, o cal implica que en todo este proceso os indíxenas están ausentes".

Os conventus, como novas demarcações territoriais, são fixados pelo poder imperial que também é quem decide quantos terão em cada província, qual será o seu tamanho e extensão, que povos serão atribuídos a cada um deles e quais serão as suas capitais. Os conventus permitirão controlar as comunidades submetidas por meios que já não são exclusivamente militares. Dessa forma, cria-se mecanismos para uma estrutura administrativa estável e permanente. E esses mecanismos se encaixam na obra de reorganização de Augusto que compreende a utilidade dos conventus como manifestação do poder de Roma e como meio de controle mais efetivo das comunidades. "A súa implantación obtivo uns frutíferos resultados para os fins que se proponía, grazas, entre outros, á utilización de recursos ideolóxicos como o culto imperial" (DOPICO CAÍNZOS, 2009: 40).

Segundo Le Roux (2014: 36),

"O conventus de época imperial, apesar de uma filiação com os do período republicano, tem um caráter territorial que não tinha precedentes definidos por um agrupamento localizado de cidadãos romanos reunidos para preservar e fazer valer seus interesses longe de sua cidade de origem. (...) A novidade, é, portanto, a noção de competência judiciária constituída a partir de um centro de assentos (sedes) escolhidos, dos quais dependiam para ajustiça de nível superior as comunidades inscritas na lista oficial cuja constituição pertencia à autoridade administrativa".

A escolha desses locais que funcionariam como polos do poder romano foi crucial num território que não possuía cidades. Por isso, a fundação por Augusto de três núcleos urbanos no Noroeste peninsular, que passaram a funcionar como capitais administrativas, foi de extrema importância para a pacificação, controle e organização da região (CARVALHO, 2008: 97).

De acordo com Pérez Losada (2002: 25), “A Civitas latina non está constituída a penas polo núcleo urbano, senón tamén polo conxunto de terras que lle serven de sustento económico e social: 'civitas' = 'urbs' + 'territorium'”.

60 Os conventus iuridici aparecem documentados desde finais do período republicano, ou seja, anteriormente ao governo de Augusto. E, provavelmente, não tinham sede fixa tampouco uma periodicidade determinada (DOPICO CAÍNZOS, 2009: 37). 
Essa nova articulação do território relaciona-se diretamente aos cursus publicus, que também dependiam dessas divisões conventuais. Assim, a criação de centros urbanos que assegurassem a administração do território e constituíssem os cenários de representação da ideologia e do poder de Roma e a construção de uma eficaz e densa rede viária representam importantes pilares do modelo que foi aplicado no Noroeste Peninsular (MARTINS, 2009b: 181).

Nesse processo de construção territorial, pode-se verificar, pelo menos, três fases de atuação (MENÉNDEZ DE LUARCA \& SORIA Y PUIG, 1994: 67-86):

- Ocupação: pacífica ou militar desse território;

- Ordenamento: ou organização geral do território ocupado conforme os novos critérios, interesses e tecnologias;

- Consolidação: do novo ordenamento, que tem lugar em dois planos: no das construções e no dos significados.

Tal como a ocupação, o novo ordenamento, bem como a sua consolidação, possibilita e requer numerosas e diversas construções, as quais, conjuntamente, constituem a topografia artificial, e fazem do território um artefato.

Após ocupado, o território será ordenado e conformado mediante três operações básicas:

- Delimitação: que consiste em definir o espaço ocupado, face a outros grupos e a outros âmbitos, e marcar os limites da jurisdição do poder que os desenha, bem como as delegações de poder que institui;

- Hierarquização: ou seja, o estabelecimento dos centros ou sedes, a partir dos quais será exercido o poder sobre o âmbito delimitado;

- Integração: dos centros com os espaços deles dependentes, mediante vias, que dividem o território em unidades menores e que as tornam acessíveis.

A superfície é o suporte do território e, consequentemente, o seu elemento constitutivo básico. Mas uma superfície só se define quando são estabelecidos os seus contornos, isto é, quando se traçam as linhas ou limites que a demarcam.

Os núcleos urbanos serão os lugares nos quais se concentram funções políticas e administrativas - as paisagens do poder estatal (PARCERO-OUBIÑA et al., 2016: 228) - construídas a partir de modelos urbanísticos padronizados ao longo do império.

As três sedes conventuais, são fundações coevas e estão muito bem localizadas em relação aos seus territórios. Apesar da criação desses núcleos urbanos resultar, provavelmente, de uma mesma decisão política, podendo ter ocorrido por volta do ano 16 a.C., como é hoje aceito pela maioria dos autores, a história, características e desenvolvimento de cada um desses núcleos são diferenciados, porque são diversificados os substratos culturais pré-romanos dessas regiões em que se implantaram (MARTINS et al., 2005).

Segundo Bonametti (2010: 260),

A evolução histórica da paisagem urbana e dos seus processos de intervenções mostra claramente que sempre se procurou formas para expressar o ideal de poder; refletindo os seus padrões políticos, 
econômicos, estéticos e culturais, a integração e a compatibilidade entre a arte e a técnica.

'Nesse contexto, as cidades fundadas por Augusto no Noroeste Peninsular desempenharam um papel fundamental na consolidação da política imperial, pois constituíram polos agregadores, atuando como centros administrativos, como elos da rede viária e como locais de residência das elites, cujo papel foi fundamental na criação de uma nova ordem social, econômica e cultural' (MARTINS, 2009b: 181).

Segundo Alarcão (1992: 35),

A cidade é lugar central que hierarquiza sítios à sua volta e exerce funções de que a população rural do território carece ou beneficia. A cidade estrutura ou ordena o território em que se insere ou do que é capital.

É nesses núcleos urbanos principais e, em menor medida, em alguns núcleos secundários (como A Coruña, Tui, Vigo ou Iria Flavia), onde se concentrará a maior parte da nova população no Noroeste nesse momento, e que constitui um estrato social de administradores, técnicos, etc. Junto aos seus modos de vida, importam também os seus modos de habitar, as suas arquiteturas e as formas de conceber 0 espaço, que podem ser vistas refletidas nesses contextos urbanos (PÉREZ LOSADA; ACUÑA PIÑEIRO, 1998; PARCERO-OUBINA, AYAN VILA, CRIADO-BOADO, BALLESTEROS-ARIAS, 2016: 229)

Vários espaços públicos, como também privados, das sedes conventuais seguem esses modelos padronizados. Uma das formas essenciais de reprodução e representação do poder é a padronização arquitetônica, que produz uma identidade compartilhada em todo o território. ' $\mathrm{O}$ Estado planificou uma cidade more romano, com malha ortogonal e retilínea, e com os espaços públicos fundamentais para o desenvolvimento das atividades administrativas, como o forum, com as infraestruturas necessárias para cumprir sua atividade administrativa' (DOPICO CAÍNZOS, 2016: 93).

O Cadastro centuriado foi o que mais caracterizou o parcelamento cadastral romano. O território era dividido em quadrícula ortogonal com parcelas retangulares denominadas de centurias. Cada uma delas tinha dimensões constantes e separavase das centúrias vizinhas por limites ou marcos que identificavam a quadrícula. Essa parcela não é apenas um cadastro, mas também a gênese e fundamento do edificado (LAMAS, 1993: 86).

De acordo com Helena Carvalho (2008: 418-419),

(...) essa organização e delimitação do espaço rural foi realizada com as finalidades comuns a qualquer ordenamento e controle do espaço, nomeadamente uma intenção de controle fiscal e de tributação, servindo igualmente para a fixação de populações indígenas.

O Cadastro centuriado era formado por dois eixos correspondentes a limites especiais: kardo e decumanus. As centurias identificavam-se segundo a linha que ocupavam a Norte ou a Sul do eixo horizontal Leste-Oeste (decumanus maximus) e a coluna do eixo vertical Norte-Sul (kardus maximus). A disposição desses dois traçados 
ortogonais principais, em sua orientação e posição recíproca, provinha de atributos cósmicos e religiosos (LAMAS, 1993: 99).

Para Lamas (1993: 98-99),

O traçado é um dos elementos mais claramente identificáveis tanto na forma de uma cidade como no gesto de a projetar. Assenta num suporte geográfico pré-existente, regula a disposição dos edifícios e quarteirões, liga os vários espaços e partes da cidade, e confunde-se com o gesto criador.

Com relação a padronização arquitetônica, a tipologia edificada determina a forma urbana, e a forma urbana é condicionadora da tipologia edificada (LAMAS, 1993: 86). A monumentalização, também, compõe a fisionomia urbana. Para Lamas (1993: 104), o monumento desempenha um papel essencial no desenho urbano, caracterizando a área, que torna-se polo estruturante da cidade.

De acordo com Kevin Lynch (1997), no estudo da paisagem urbana, - além do sistema viário - estes aspectos são imprescindíveis para a "legitibilidade" do ambiente urbano, haja vista a necessidade de identificação de aspectos físicos presentes e/ou visíveis.

Para Helena Carvalho (2008: 124),

(...) a política de monumentalização dos espaços das cidades articula-se com a expansão territorial, alicerçada na consolidação da rede viária e no investimento sobre algumas manchas periféricas à primeira matriz urbana desenhada no tempo de Augusto. Articulação esta que revela um alcance político global que demonstra e reforça a imagem e poder de Roma nas províncias.

Essa forma de ver e entender o território implica a gênese de uma nova estrutura de apropriação do espaço. Ainda que a experiência cotidiana da maior parte dos habitantes do Noroeste esteja limitada ao seu mundo local, próprio de comunidades camponesas; por cima disso se impõe uma forma diferente, mais global de entender o território e de construir a paisagem.

Bracara Augusta, Asturica Augusta e Lucus Augusti partilham entre si, além de uma possível data de fundação comum, a função administrativa que desempenharam na província Tarraconense enquanto capitais de conventus; uma possível origem jurídica semelhante, pelo menos, como cidades de direito latino (LE ROUX, 1994); uma estrutura urbana planificada e funções centralizadoras como nós viários estruturantes do território.

As três cidades conventuais do Noroeste foram criadas dentro do planejamento geral do circuito conventual da Citerior, o que significava organizá-las de modo que o governador provincial poderia viajar de forma acessível. As comunicações naturais ou os caminhos utilizados anteriormente pelos indígenas não eram suficientes para o poder romano, que teve que criar a sua própria rede, adaptada às suas necessidades. Alguns miliários que sobreviveram, nos permitem ver que esta nova rede de estradas já estáva em execução no tempo de Augusto (RODRIGUEZ COLMENERO, 2004: 158, 
$199,268,275,295)$, demonstrando, mais uma vez, um planejamento de acordo com as novas funções administrativas.

A seguir, apresentamos uma síntese sobre as três sedes conventuais fundadas por Augusto: Bracara Augusta, Lucus Augusti e Asturica Augusta.

\subsubsection{Bracara Augusta}

Bracara Augusta (atual Braga, Portugal) apresenta boa comunicação fluvial e terrestre bem como acesso ao oceano Atlântico. Os dados arqueológicos demonstram que foi uma fundação ex nihilo, fundação de raiz, implantada no interflúvio dos rios Cávado e Este; localizada no cruzamento de eixos de comunicação naturais. Fica situada no coração da região mais desenvolvida e densamente povoada durante a Idade do Ferro.

A escolha do local para instalar a cidade deve ter sido determinada pela posição central relativamente aos povoados indígenas da região. Entretanto, também é possível que o mesmo fosse zona de confluência de vários eixos de comunicação préromanos, que articulavam a costa atlântica ao restante território do Noroeste e a região já pacificada do Sul da Península Ibérica (MARTINS 1990; LEMOS 2002; MORAIS 2005). Para Tranoy (1981), Bracara está situada em um local propício as trocas devido a reunião de povos pré-romanos em seu entorno.

Os trabalhos arqueológicos desenvolvidos em Braga nas últimas décadas tem fornecido importantes informações sobre sua constituição. Bracara Augusta possuía uma malha ortogonal, orientada segundo eixos de orientação Norte-Noroeste/SulSudeste e Sudoeste-Oeste/Nordeste-Leste, com módulos quadrados de 150 pés, que definiam os quarteirões, os quais possuíam uma área de construção aproximada de 1 actus quadrado (MARTINS, 1999; MARTINS, 2004; CARVALHO, 2008).

Esta malha urbana, que foi recuperada a partir de muros, de infraestruturas viárias, de circulação como ruas e pórticos, pela orientação de cloacas, demonstra que a criação dessas infraestruturas de saneamento na cidade, tenha ocorrido no período fundacional, momento em que deve ter sido implantada a malha ortogonal (MARTINS; DELGADO 1989-90; CARVALHO, 2008).

Em Bracara Augusta a maior parte dos edifícios conhecidos está datada do período Flávio ou Flávio-Antonino, circunstância que pode ser decorrerência da profunda renovação ocorrida entre o último quartel do século I e meados do século II (CARVALHO, 2008: 118).

As Figuras 3.3.1.a e 3.3.1.b foram produzidas a partir da realização de caminhamento em diferentes setores da cidade de Braga, em julho/agosto de 2012 e julho/2013, com o objetivo de reconhecimento da paisagem, demarcação com auxílio de GPS, anotações em caderno de campo e registro fotográfico das áreas de interesse arqueológico para o posterior cruzamento dos dados em um Sistema de Informação Geográfica.

As principais evidências arqueológicas romanas espacializadas em Braga foram: Balneário Pré-Romano, Fonte do Ídolo, Termas Romanas do Alto da Cividade, Teatro romano do Alto da Cividade, Cloaca e Pórtico - Ex-Albergue Distrital (Biblioteca Lúcio 
Craveiro da Silva), Cloaca, Domus Escola Velha da Sé, Ínsula das Carvalheiras, Largo de São Paulo - Marcação no Pavimento, Domus de Santiago, Mosaico in situ - Museu Dom Diogo de Sousa, Inscrição romana - Fachada da Sé, Inscrição dedicada a Ísis, Inscrição Romana da fachada do Largo João Peculiar, Domus das Frigideiras do Cantinho, Trecho Muralha - Sé Catedral, Trecho Muralha - Sé Catedral. 


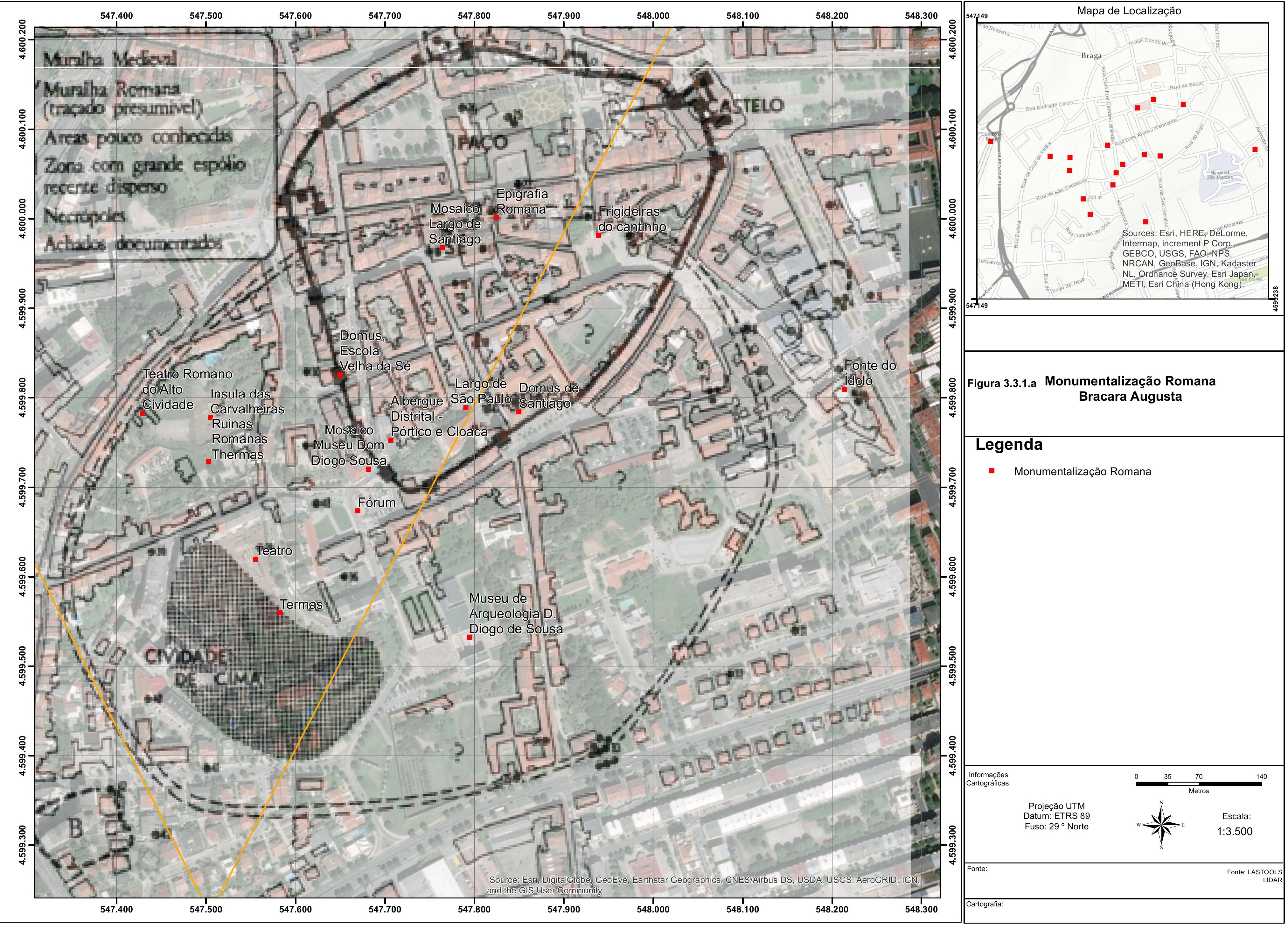




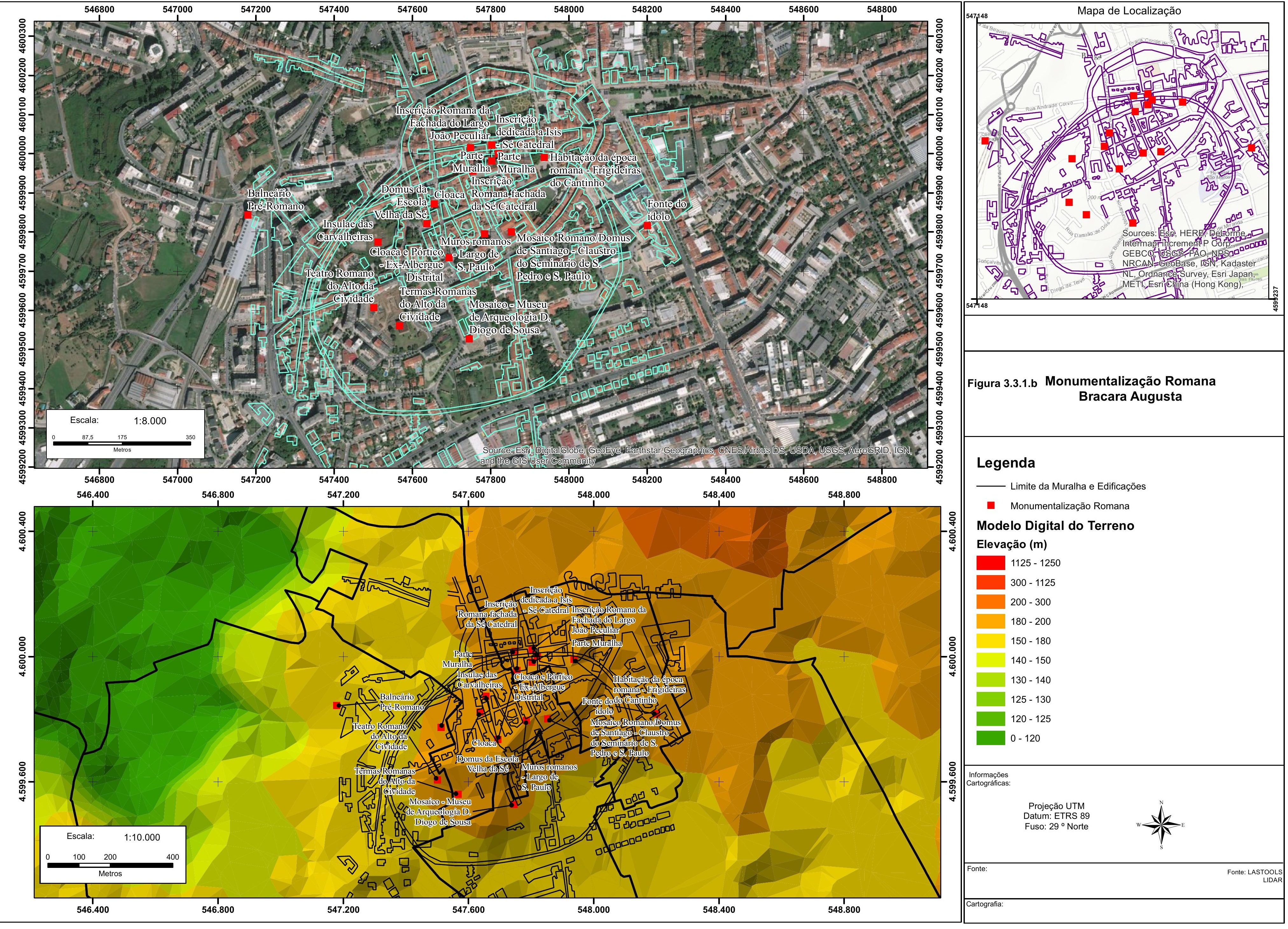




\subsubsection{Asturica Augusta}

Asturica Augusta (atual Astorga, Espanha), a Urbs Magnífica de Plínio, está próxima de dois cursos fluviais, além de estar localizada em zona de vastos depósitos auríferos. Tem origem militar, comprovada, num acampamento onde estacionou a Legio $X$ Gemina. A passagem de acampamento à cidade enquadra-se no projeto empreendido por Augusto de fundação de três cidades no Noroeste, que irão funcionar como capitais conventuais, no período que se segue às guerras cantábricas (FERNÁNDEZ OCHOA; MORILLO CERDÁN, 1999; SEVILLANO FUERTES; VIDAL ENCINAS, 2002; CARVALHO, 2008).

Entre finais do século I a.C. e inícios do I d.C., Asturica Augusta passou de acampamento militar a cidade, tendo uma planificação ortogonal que se adaptou às condicionantes topográficas locais. No setor ocidental dominavam os eixos Noroeste/Sudeste, enquanto que no oriental a cidade se organizou em função de eixos de orientação Norte/Sul, mais adaptados às características da zona (GARCIA MARCOS; VIDAL ENCINAS, 1998). São realizadas uma série de infraestruturas urbanas, tais como uma rede de eixos viários, além de edifícios públicos e algumas ricas residências privadas. É também conhecida a infraestrutura sanitária da cidade, composta por uma ampla rede de cloacas, cuja construção remonta aos inícios do século I. O forum estava localizado num dos pontos mais elevados da cidade, articulando os setores urbanos oriental e ocidental. (SEVILLANO FUERTES; VIDAL ENCINAS 2002; CARVALHO, 2008).

Asturica estava estreitamente ligada a exploração minerária. Estava situada em local estratégico de controle da região aurífera do Noroeste e importante plataforma viária de escoamento de produtos, o nó viário para Tarraco e para Mérida (Via da Prata). Asturica Augusta teve o seu auge na época da exploração dos recursos mineiros da região, nos séculos I e II. Nesse contexto, foi um importante centro administrativo, com funcionários de altos cargos que fixaram residência, particularmente procuratores augusti, legati iuridici, e altos funcionários ligados ao exército, às finanças, ao recrutamento, ao censo e à tributação (TRANOY, 1981; CARVALHO, 2008).

Sabe-se, pelo dossiê epigráfico, que sua composição social registra grande número de imigrantes oriundos de diferentes partes da Hispânia, bem como de outras regiões do Império (TRANOY, 1981; 1986; CARVALHO, 2008). Devido ao nível sócioeconômico da população residente, a cidade conheceu vários programas de renovação urbana e a construção de residências de grande riqueza e requinte. Quando a exploração de ouro decai a cidade entra em crise (BURÓN ALVAREZ, 1997; CARVALHO, 2008).

As Figuras 3.3.2.a e 3.3.2.b foram produzidas a partir da realização de caminhamento em diferentes setores da cidade de Astorga, em julho de 2013, com o objetivo de reconhecimento da paisagem, demarcação com auxílio de GPS, anotações em caderno de campo e registro fotográfico das áreas de interesse arqueológico para o posterior cruzamento dos dados em um Sistema de Informação Geográfica.

As principais evidências arqueológicas romanas espacializadas em Astorga foram: Fosso do acampamento romano da Legio X Gemina, Termas, Forum Romano, 
Aedes Augusti, Domus do Mosaico del Oso y los Pájaros, Cloaca, Porta Romana, Muralha. 


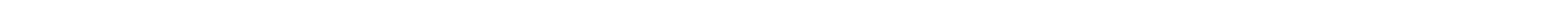




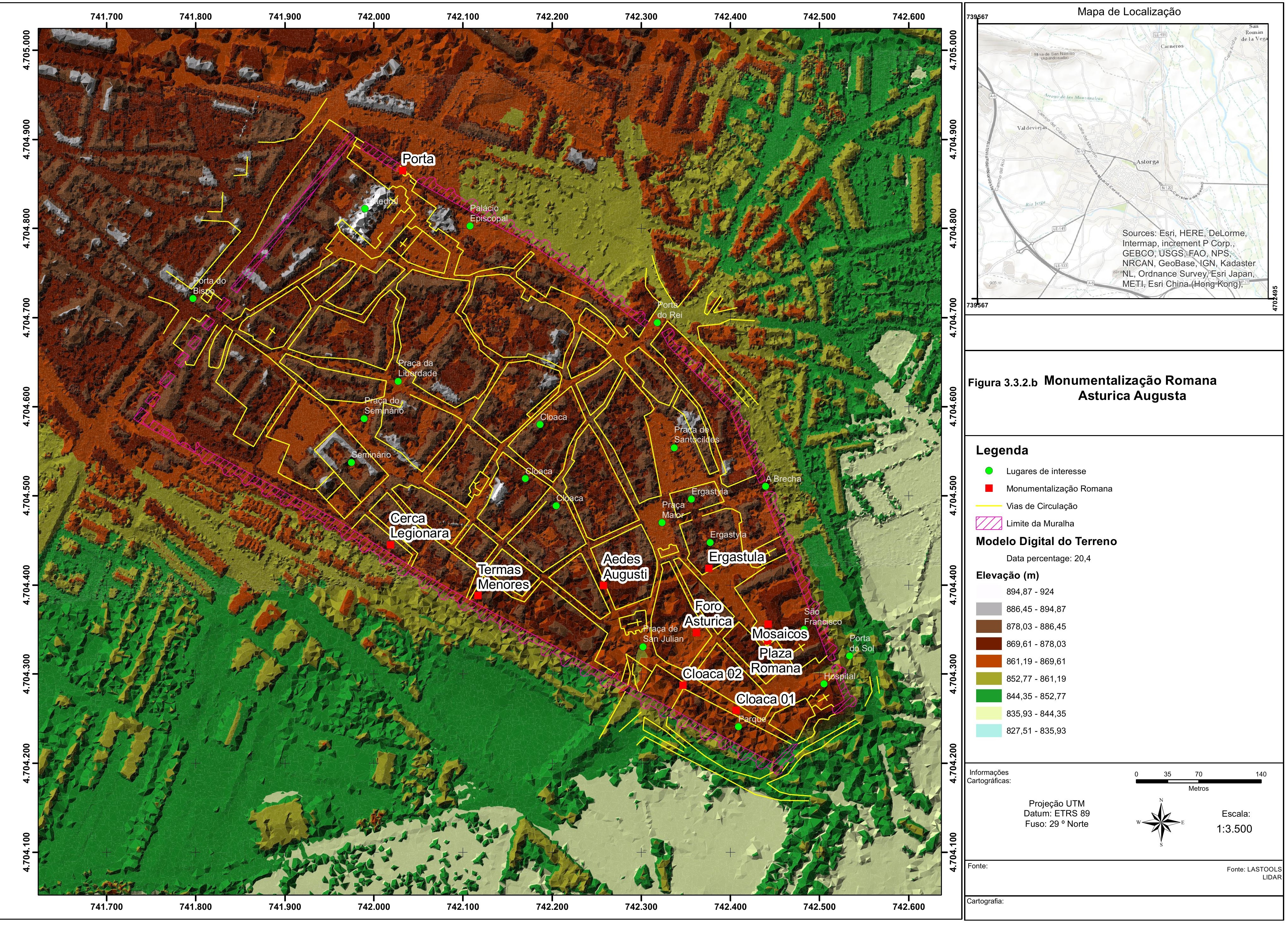




\subsubsection{Lucus Augusti}

A cidade de Lucus Augusti (atual Lugo, Espanha) foi fundada a partir de acampamento militar, com o assentamento da $\mathrm{L}($ egio) $\mathrm{VI}$, uma das legiões intervenientes na conquista do Noroeste. Está implantada em uma área inclinada para Sudoeste, com horizontes abertos até às regiões costeiras, num local estrategicamente importante como nó viário (RODRÍGUEZ COLMENERO 1995; CARVALHO, 2008). Lucus Augusti não apresenta barreiras geográficas significativas em relação a população de seu conventus; tem uma boa saída externa para a Meseta, além de controlar um trecho navegável do Minho que a comunica com as zonas auríferas ao Sul.

Lucus Augusti teve, portanto, uma primeira ocupação como acampamento militar que precedeu o núcleo urbano, tendo sido habitada por populações pré-romanas que estiveram envolvidas nas tarefas de construção da cidade.

A primeira fase urbanística de Lucus Augusti, situada entre finais do século I a.C. e meados do século I d.C., é, como em Bracara e Asturica, pouco conhecida. Das primeiras décadas do século I documentam-se apenas alguns edifícios e construções, aparecendo, no entanto, materiais cerâmicos característicos desta fase. Durante a época júlio-claudiana a cidade conheceu um primeiro período de implantação de equipamentos urbanos e edifícios públicos dentro e fora da cidade, (RODRÍGUEZ COLMENERO 1995; GONZÁLEZ FERNÁNDEZ; CARREÑO GASCÓN, 1998; CARVALHO, 2008).

As Figuras 3.3.3.a e 3.3.3.b foram produzidas a partir da realização de caminhamento em diferentes setores da cidade de Lugo, em julho de 2013, com o objetivo de reconhecimento da paisagem, demarcação com auxílio de GPS, anotações em caderno de campo e registro fotográfico das áreas de interesse arqueológico para o posterior cruzamento dos dados em um Sistema de Informação Geográfica.

As principais evidências arqueológicas romanas espacializadas em Lugo foram: Muralha, Portas, Cloaca, Necrópoles de cremação, Necrópoles de Inumação, Piscina, Aqueduto, Casa dos Mosaicos Batitales e Centro Arqueológico São Roque. 

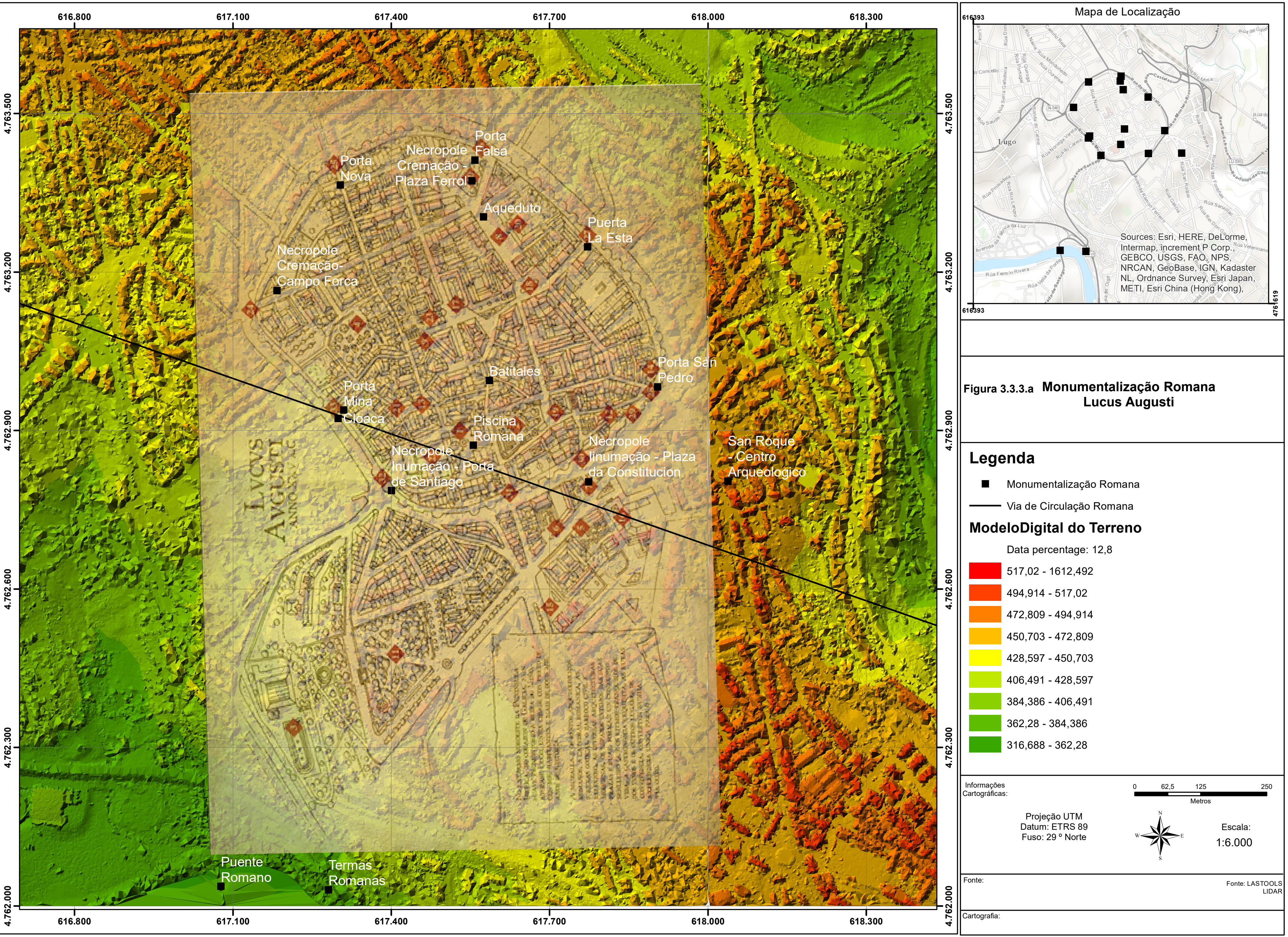


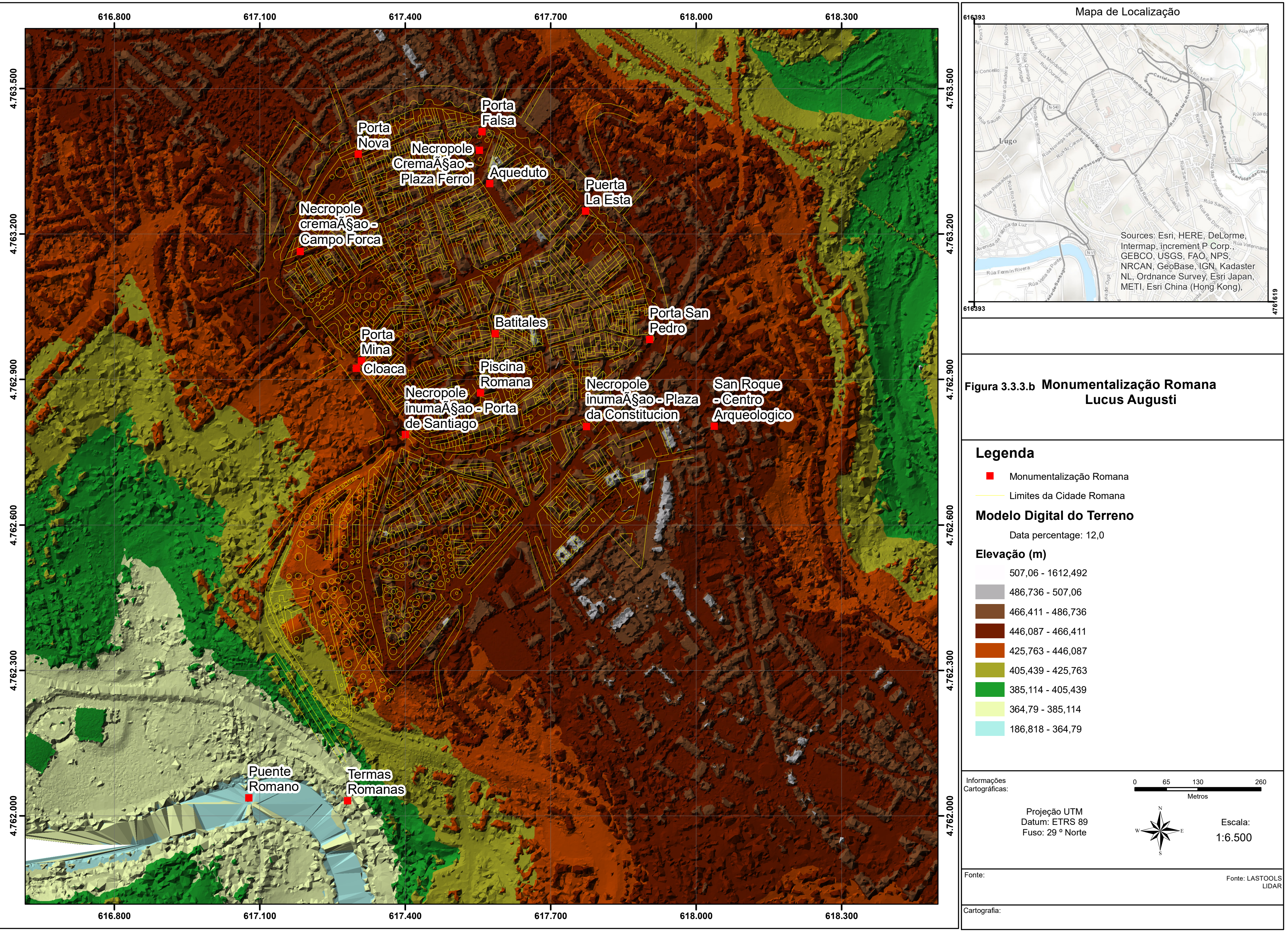




\subsubsection{Aglomerados Secundários}

No mesmo período no qual se consolida o poder e a monumentalidade das fundações de Augusto no Noroeste Peninsular constata-se uma expansão de novos núcleos urbanos secundários, por toda a região (CARVALHO, 2008: 127). Esse fenômeno ocorrerá entre a época de Augusto e a época Flávia-Antonina e pode estar ligado a um segundo momento da reorganização territorial, quando acontece a promoção municipal (FERNANDEZ OCHOA; MORILLO CERDÁN, 1999; PÉREZ LOSADA, 2002; CARVALHO, 2008: 127).

Frente as cidades, a imensa maioria do território segue sendo um âmbito rural, onde a população continuará habitando em povoados fortificados que pouco se diferem dos anteriores (FONTE, 2009; 2015; AYÁN VILLA, 2005, 2012). Pela primeira vez, esse território passa a estar organizado a partir de uma dualidade urbano-rural. Segundo Parcero-Oubiña et al. (2016: 228):

Ainda que é certo que o desenvolvimento urbano romano no noroeste non é comparable ao doutras zonas do imperio, a estruturación do espazo que Roma define baséase no principio esencial de separación de funcións entre os núcleos urbanos e os espazos rurais.

Ainda que seja possível identificar algumas novidades, em muitos casos, os modos de vida e as formas de relação desses castros com seu entorno não mudarão de forma significativa até que, a partir do século II, começam a ser abandonados e a ser substituídos por assentamentos abertos.

A mudança que nos interessa à ser analisada diz respeito a formação de um território articulado a partir do que podemos definir como uma paisagem de nós, linhas e rede. Pela primeira vez, ocorre que o território é visto a partir de uma escala de compreensão e gestão global, muito mais extensa que a dos limitados âmbitos de experiência e habitação anterior, relacionados aos castros.

Se durante a Idade do Ferro o espaço ao redor dos castros podia ser compreendido em termos de território; agora é todo o Noroeste que é percebido como um âmbito interdependente, e por sua vez integrado em um âmbito ainda mais extenso, como é a totalidade do império.

Observa-se claramente que a grande maioria dos aglomerados secundários poderiam ser considerados nós viários (PÉREZ LOSADA, 2002: 327). As vias de comunicação, quase sempre, constituem pontos de passagem obrigatórios, espaços de confluência e cruzamento de vias.

Segundo Pérez Losada (2002: 327),

A nível meso e macroespacial resulta evidente que o fator essencial de fixación son as comunicacións terrestres. Tódolos aglomerados considerados están situados sobre o trazado de vías estatais primarias (...).

"O traçado estabelece a relação mais direta de assentamento entre a cidade e o território" (LAMAS, 1993: 99). Assim se desenham, tanto a via XVII, que ligava Bracara Augusta com Asturica Augusta, quanto a via XIX, que também unia essas duas 
capitais passando pela terceira, Lucus Augusti; e a via XVIII, que colocava em comunicação a região aurífera de Las Medulas com as capitais conventuais de Bracara Augusta e Asturica Augusta (Figura 3.3.4.a).

Figura 3.3.4.a

Centros urbanos e vias de comunicação no Noroeste Peninsular em época romana

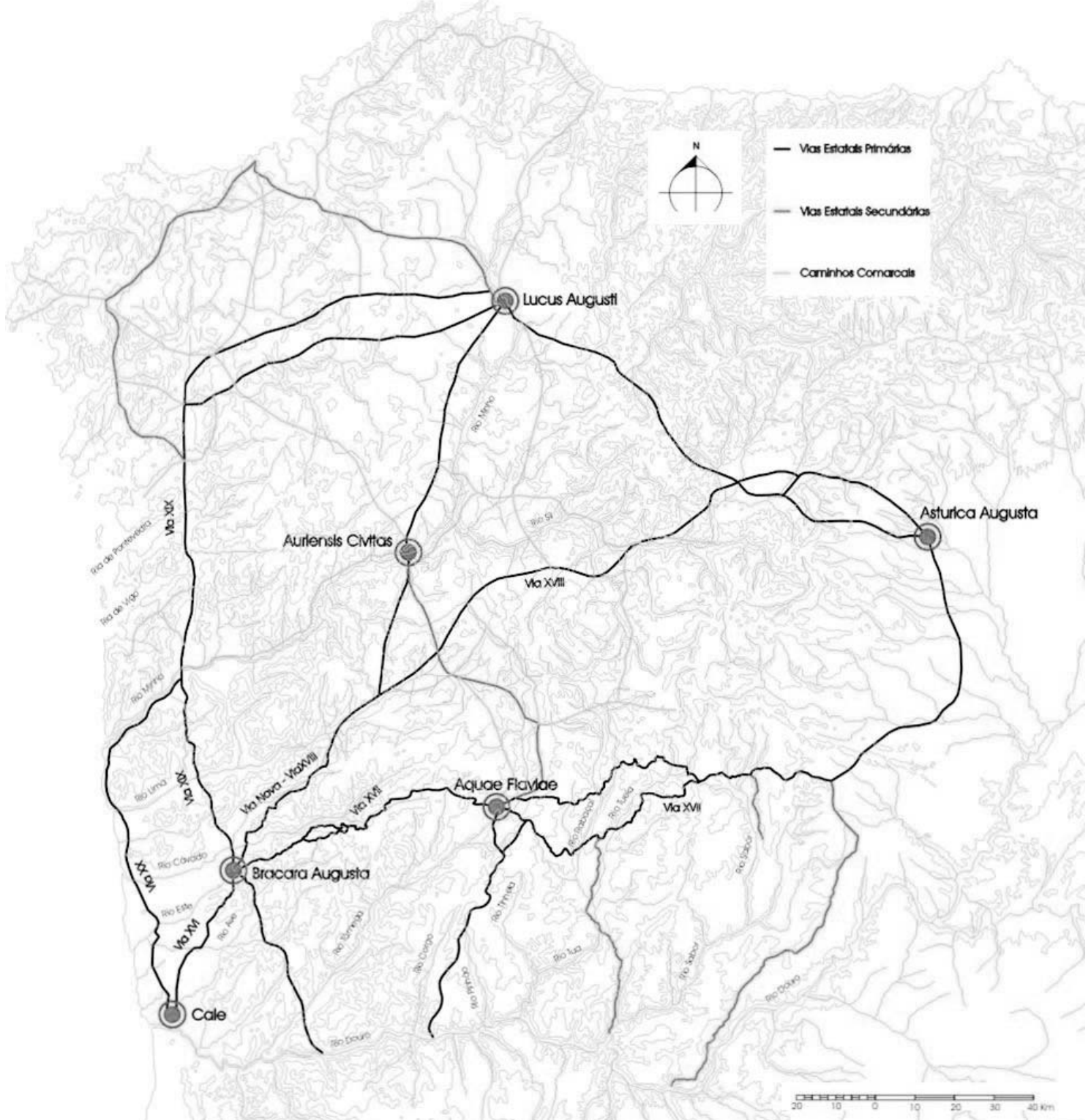

Fonte: Fonte, J. (2006: 07, Figura 4).

A partir do Noroeste se ligaria com o resto do percurso conventual, que é muito consistente, mostra não só que as cidades estavam localizadas em locais de fácil acesso para as comunidades incluidas em seus respectivas conventus, como, também, estavam dispostas de modo a fornecer um caminho quase linear de Tarraco a Asturica Augusta onde a estrada se bifurca devido a localização das três capitais do Noroeste, que se encontravam dispostas de forma praticamente triangular.

Os eixos centrais que lhe dão sentido são esses pontos nodais, os nós, lugares concretos que desempenham funções específicas. E o esqueleto que os articula são as linhas constituídas por uma extensa rede viária (PARCERO-OUBINA, AYAN VILA, 
CRIADO-BOADO, BALLESTEROS-ARIAS, 2016: 231). Dessa forma, o espaço se efetiva nas conexões, nos encontros (MASSEY, 2008).

O território é contemplado como uma malha de lugares setorialmente especializados em diferentes funções dentro do esquema de funcionamento do império. Alguns lugares operam como centros administrativos; outros são centros de produção econômica mineira, como a grande quantidade de explorações auríferas, concentradas no interior da Galícia e na área de Astúrias e León (SÁNCHEZPALENCIA, F. J.; FERNÁNDEZ-POSSE, FERNÁNDEZ-MANZANO \& OREJAS, 1996).

\subsubsection{Zona Arqueológica de Las Medulas}

$\mathrm{Na}$ zona de Las Medulas do Bierzo, junto ao rio Sil, observa-se, a partir do século I, o surgimento de novos núcleos de povoamento de característica rural com atividades agrárias mais intensivas. Alguns desses núcleos também estão relacionados com atividades de mineração, como por exemplo, em áreas de extração ou de lavagem; com a rede de água que abastecia as minas; e ainda na fabricação de fermamentas de ferro, como no povoado de Orellan (SÁNCHEZ-PALENCIA; OREJAS SACO DEL VALLE, 1998; SÁNCHEZ-PALENCIA; FERNÁNDEZ-POSSE, FERNÁNDEZ-MANZANO, 1999; SÁNCHEZ-PALENCIA, 2001; FERNÁNDEZ-POSSE; MENÉNDEZ; SÁNCHEZ-PALENCIA, 2002).

A água foi a principal energia para a exploração aurífera da zona de Las Medulas, que era feita a grande escala e, portanto, se criou uma enorme rede hidráulica com canais de abastecimento (corrugi), tanques de armazenamento (piscinae) e canais de exploração (emisaria).

A obra "Naturalis Historia" de Plinio, o Velho, é a fonte textual que mais fornece detalhes sobre o funcionamento e importância da água nas atividades de mineração na zona de Las Medulas. O autor descreve em detalhes as atividades nas minas de ouro, dentre elas a técnica denominada 'ruina montium', pela qual as montanhas entravam em colapso total. Ainda hoje podemos observar as cicatrizes derivadas desse sistema de exploração aurífera (Figura 3.3.5.a). Essa técnica pode ser visualizada a partir do Mirante de Orellan (Figura 3.3.5.b): observa-se uma série de canais (Figura 3.3.5.c) e galerias onde a água era introduzida de modo a provocar o colapso das montanhas que se transformavam em uma massa de lama devido a ação da força da água.

Figura 3.3.5.a

Visão Geral da Zona Arqueológica de Las Medulas 


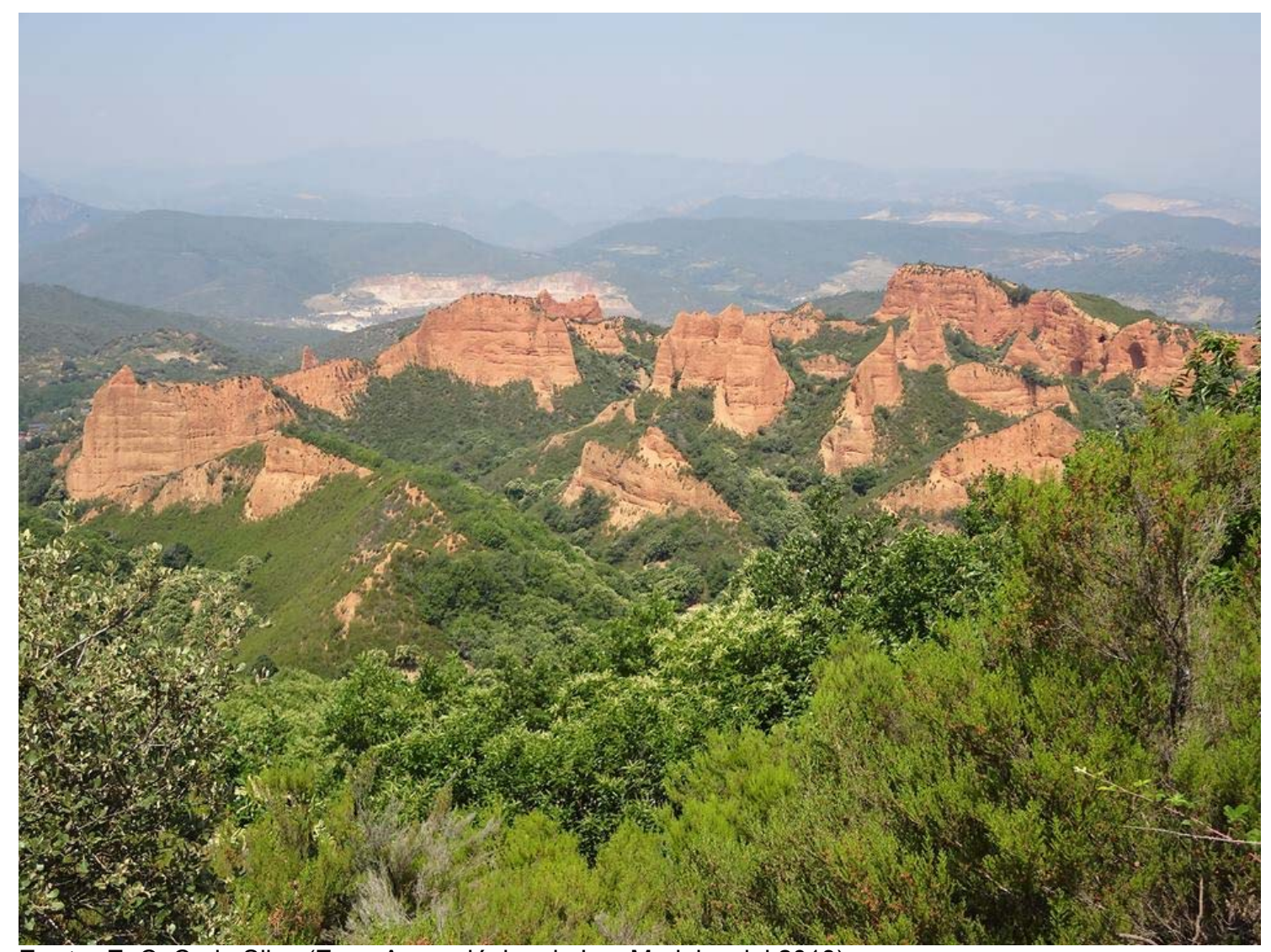

Fonte: E. C. C. da Silva (Zona Arqueológica de Las Medulas, jul.2013) 
Figura 3.3.5.b

Mirante de Orellan

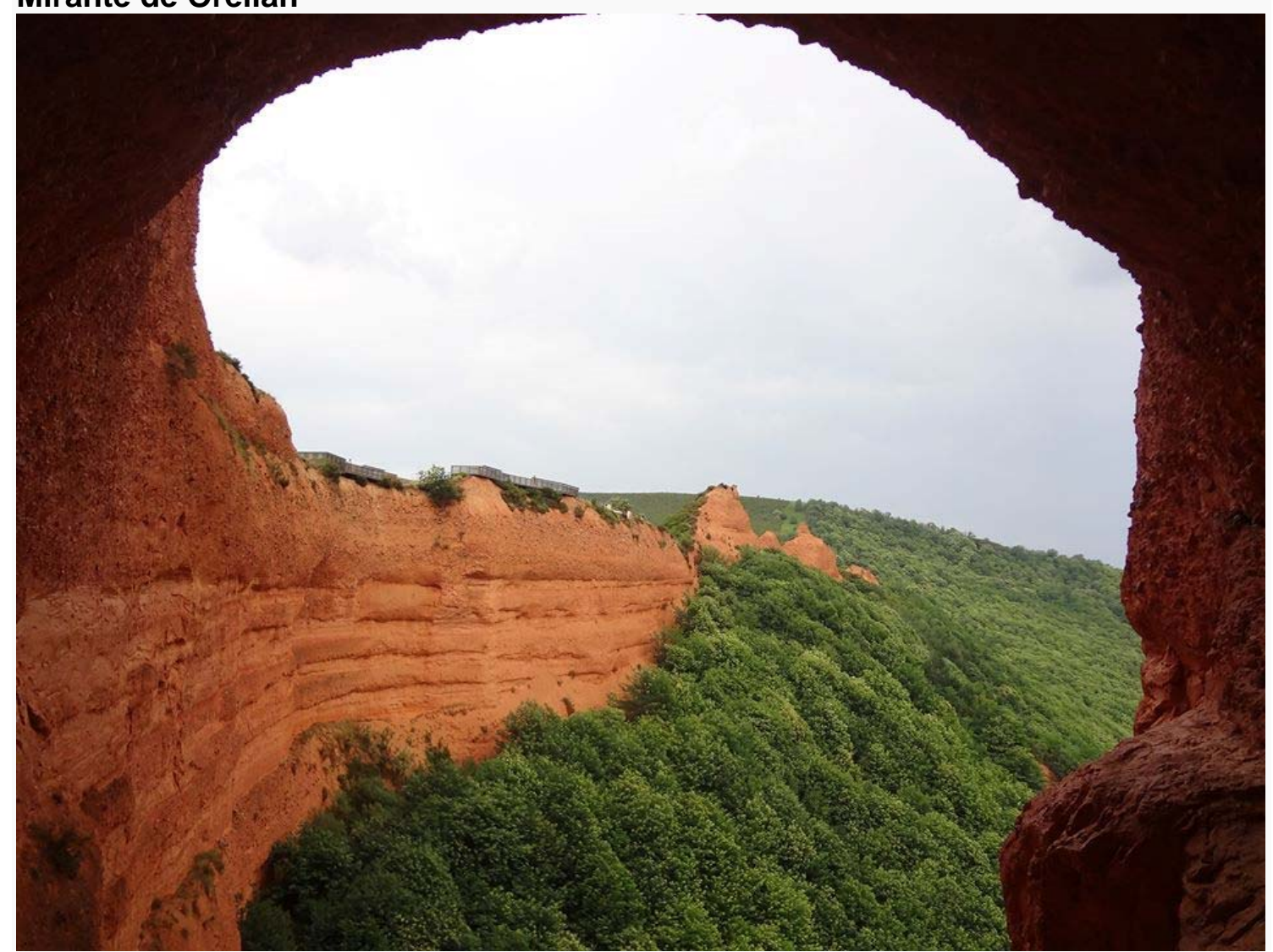

Fonte: E. C. C. da Silva (Zona Arqueológica de Las Medulas, jul.2013)

Figura 3.3.5.c

Canal romano de Peña Escribida

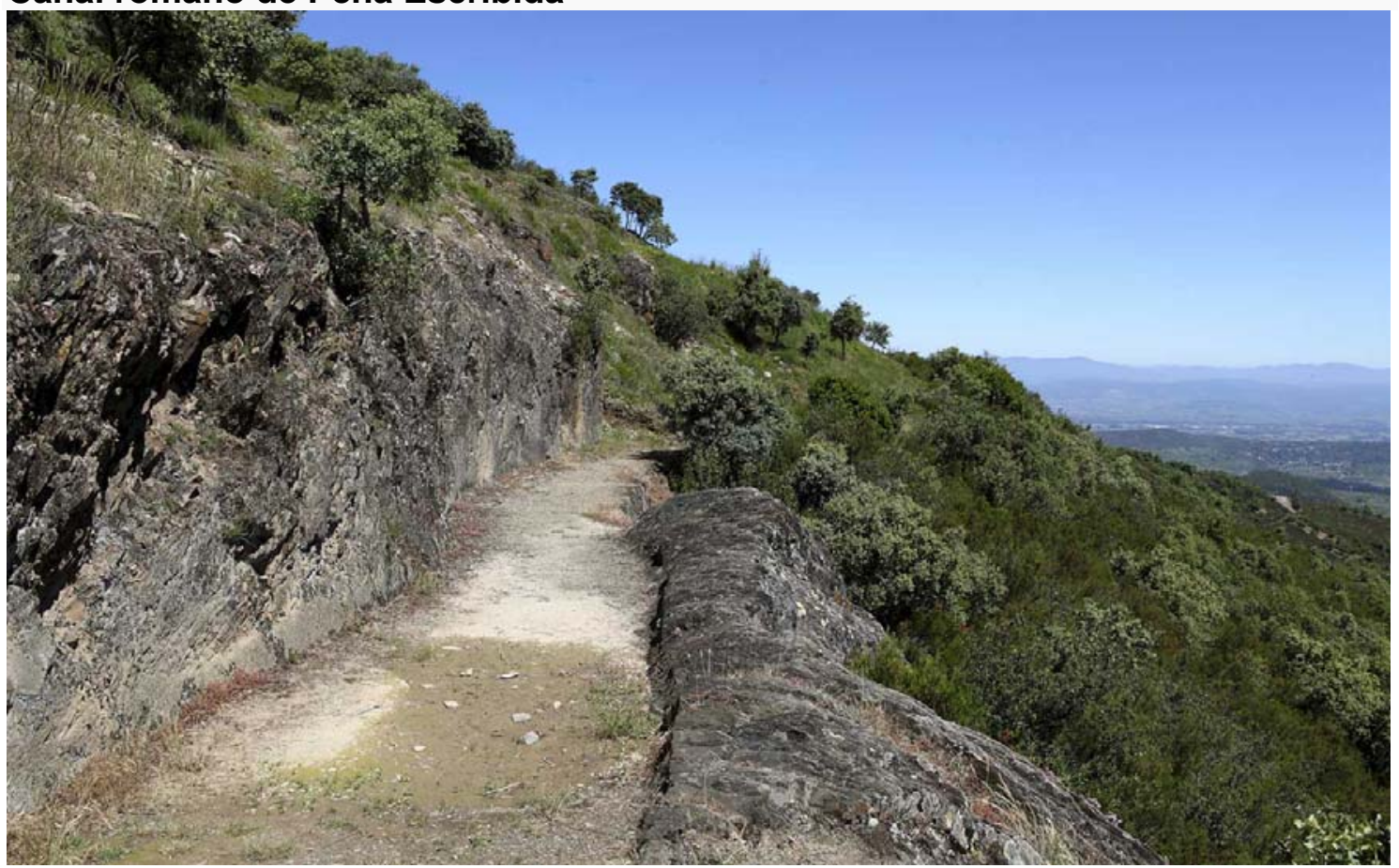

Fonte: E. C. C. da Silva (Zona Arqueológica de Las Medulas, jul.2013) 
A Figura 3.3.5.d, foi produzida a partir da realização de caminhamento na Zona Arqueológica de Las Medulas, em julho de 2013, com o objetivo de reconhecimento da paisagem, demarcação com auxílio de GPS, anotações em caderno de campo e registro fotográfico das áreas de interesse arqueológico para o posterior cruzamento dos dados em um Sistema de Informação Geográfica. No caminhamento feito nos itinerários da Senda de las Valiñas e da Senda Perimetral foi possível obter algumas informações sobre o processo de exploração romana do ouro. 


\section{CAPÍTULO 4. A LÓGICA DA REDE VIÁRIA ROMANA NO NOROESTE}

\subsection{A Rede Viária do Noroeste Peninsular}

A implantação de uma rede viária consiste em uma estratégia fundamental para a efetiva conquista e controle territorial. As estradas, como todas as grandes obras de utilidade pública, tiveram especial projeção na ideologia do Estado romano, na época republicana e, consequentemente, durante o Império. Dessa forma, foram largamente utilizadas como símbolo tanto da grandeza do Estado (KLEINER 1999: 182-192; ÁLVAREZ MARTÍNEZ; BASARRATE 2003: 255-276), como do evergetismo estatal a serviço da Res Publica, através da ação dos magistrados e do imperador (MANTAS, 2012: 141).

De acordo com Vicente González (2013: 49),

Con el paso del tiempo, las calzadas ${ }^{61}$ demostraram su utilidad para ejercer la administración de un territorio tan dilatado como fue el Imperio Romano facilitando el funcionamiento del servicio estatal de correo (cursus publicus) $y$ el desarollo del comercio global, al posibilitar el transporte continuado de ingentes cantidades de mercancías en uno y outro sentido.

Provavelmente, com o intuito de consolidar a rede de caminhos naturais existentes no Noroeste, as obras viárias sistemáticas romanas tenham se iniciado na fase inicial das campanhas terminadas em 19 a.C. por Agripa, ou no decorrer das mesmas.

A sua novidade nem é tanto o de habilitar uma série de caminhos que permitam percorrer o espaço. A intenção agora é que essa rede de caminhos se converta em um elemento material essencial na paisagem, demarcado e sancionado fisicamente. Essa rede tem como objetivo estruturar essa paisagem (PARCERO-OUBINA, AYAN VILA, CRIADO-BOADO, BALLESTEROS-ARIAS, 2016: 231). Neste sentido, inicia-se com Augusto a estruturação da rede de itinerários principais do Noroeste, que haveria de garantir a ligação dos três centros urbanos augustos e a articulação destes com as capitais provinciais e com outros centros importantes da Hispânia romana (CARVALHO, 2008).

Segundo Mantas (2016: 139),

A investigação desenvolvida ao longo das últimas décadas não permite dúvidas quanto à existência de um plano integrado para o estabelecimento de polos urbanos e respectivas vias de comunicação no Noroeste hispânico, preparando a integração plena da região, a concretizar-se com a acção dos imperadores Flávios, duas gerações depois da fase augustana.

\footnotetext{
${ }^{61}$ Calçadas são todo o caminho com possível origem romana ainda com vestígios de pavimento antigo.
} 
As vias, possivelmente atribuídas à época de Augusto são as seguintes, segundo a numeração do Itinerário de Antonino:

Item ab Olisipone Bracaram Augustam (Via XVI): It.420,8-422,1.

Item a Bracara Asturicam (Via XVII): It.422-423,5.

Item a Bracara Asturicam (Via XIX): It.429,5-431-3.

Item per loca marítima a Bracara Asturicam (Via XX): It.423,6-425,5.

Com relação ao Item alio itinere a Bracara Asturica (Via XVIII, a Via Nova), foi aberta posteriormente em época flávia, com objetivos comerciais e administrativos, e colocava em comunicação a região aurífera de Las Medulas com as capitais conventuais de Bracara Augusta e Asturica Augusta. Segundo Carvalho (2008: 419),

A construção da Via Nova inscreve-se num período histórico posterior à fundação das mais importantes cidades do Noroeste e da organização subsequente à conquista e pacificação, ou seja, insere-se numa época de consolidação do poder imperial, característica da actuação dos imperadores flávios na Hispânia.

A implantação de uma via também implicava em planejamento e estabelecimento de estruturas que funcionassem, em distâncias determinadas, como estações viárias. Esses locais recebiam diversas denominações relacionadas a sua função. Enquanto as mutationes serviam como simples estações de muda ou de breve pausa em uma jornada, sendo normalmente pequenos estabelecimentos, as mansiones possuíam maiores dimensões, configurando uma estalagem. Em uma análise geral conclui-se que a maior parte das estações identificadas pertence a categoria das mansiones, pois correspondem a cidades ou aglomerações secundarias (SILLIĖRES, 1990; CARVALHO, 2008; MANTAS, 2014). Portanto, o cursus públicus necessitava desses locais de pousio para que a rede viária fosse funcional, capaz de garantir condições para que fosse possível a exploração e controle do território.

O império romano se preocupou em desenvolver uma política urbanística viária extensa de construção de calçadas, além de sua manutenção para que Roma estivesse bem comunicada com as províncias. Para realizar os trabalhos de construção e reparação das vias, os governadores contaram com a colaboração do exército (VEGA AVELAIRA, 2001: 177-192). Nas províncias imperiais onde estavam localizados os acampamentos legionários, os militares construíam as vias que recebiam a denominação de Viae militares. As legiões, após a conquista de um território, construíam as viae militares, com a finalidade de exercer o controle militar, político e econômico de uma região em vias de pacificação (SOLANA SÁINZ; SAGREDO SAN EUSTAQUIO, 2006: 15).

A estradas constituiam um traço forte da paisagem, que ajudaram a construir, paisagem bastante complexa e da qual fazia parte uma significativa diversidade de padrões que the conferiam, simultaneamente, individualidade e unidade (MANTAS, 2012: 143).

A apropriação da natureza/paisagem implica, portanto, numa manipulação da mesma, subordinada aos fins propostos por seu dominador, o homem, no caso em destaque o Império Romano. Mas a atividade definidora e determinadora de tal 
apropriação está diretamente relacionada à organização de sua produção econômicosocial e a construção de seus valores.

Tomando como ponto de partida Bracara Augusta, e colocando-a como nó viário importante, temos as vias de ligação às outras duas cidades fundadas por Augusto: Lucus Augusti e Asturica Augusta (Figura 4.1.a). Desta última cidade partia uma série de outros itinerários que permitiam ligações à Gália e, através desta, à capital do Império.

Figura 4.1.a

Rede viária do Noroeste - Saídas de Bracara Augusta

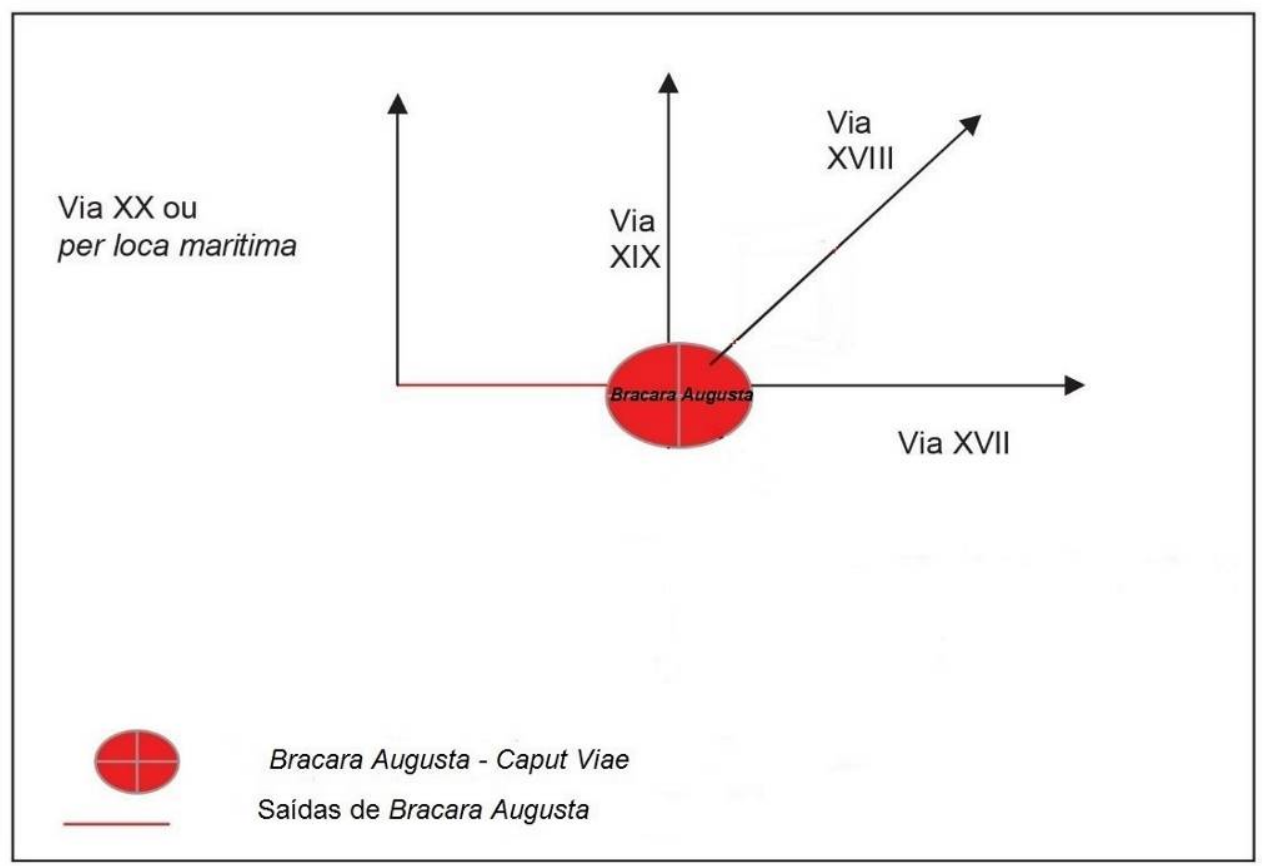

Fonte: Adaptado de Carvalho (2008: 195)

Por sua vez, os miliários que acompanham o traçado dessas vias permitem ajustar os percursos e ter uma ideia da cronologia da construção e reparação das vias, devido ao nome dos imperadores referidos nas inscrições. Grande parte desses itinerários começa a ser construído ainda em época de Augusto, prosseguindo nos governos seguintes. Os miliários estiveram no centro de tais práticas, aliando informações políticas e indicações de ordem prática, através de textos muito simples, normalmente, de forma a facilitar a leitura a quem se deslocava na estrada, ao que parece pela esquerda (MANTAS, 2012: 142).

Durante o levantamento de campo, em agosto de 2013, foi possível percorrer parte do traçado da Via XVIII, na Serra do Gerêz, Portugal. Neste caminhamento foi feito o registro fotográfico de evidências de calçada romana e miliários na via XVIII, "Via Nova", como pode ser observado na Figura 4.1.b abaixo. 
Figura 4.1.b

Miliários Romanos - Via Nova, Via XVIII

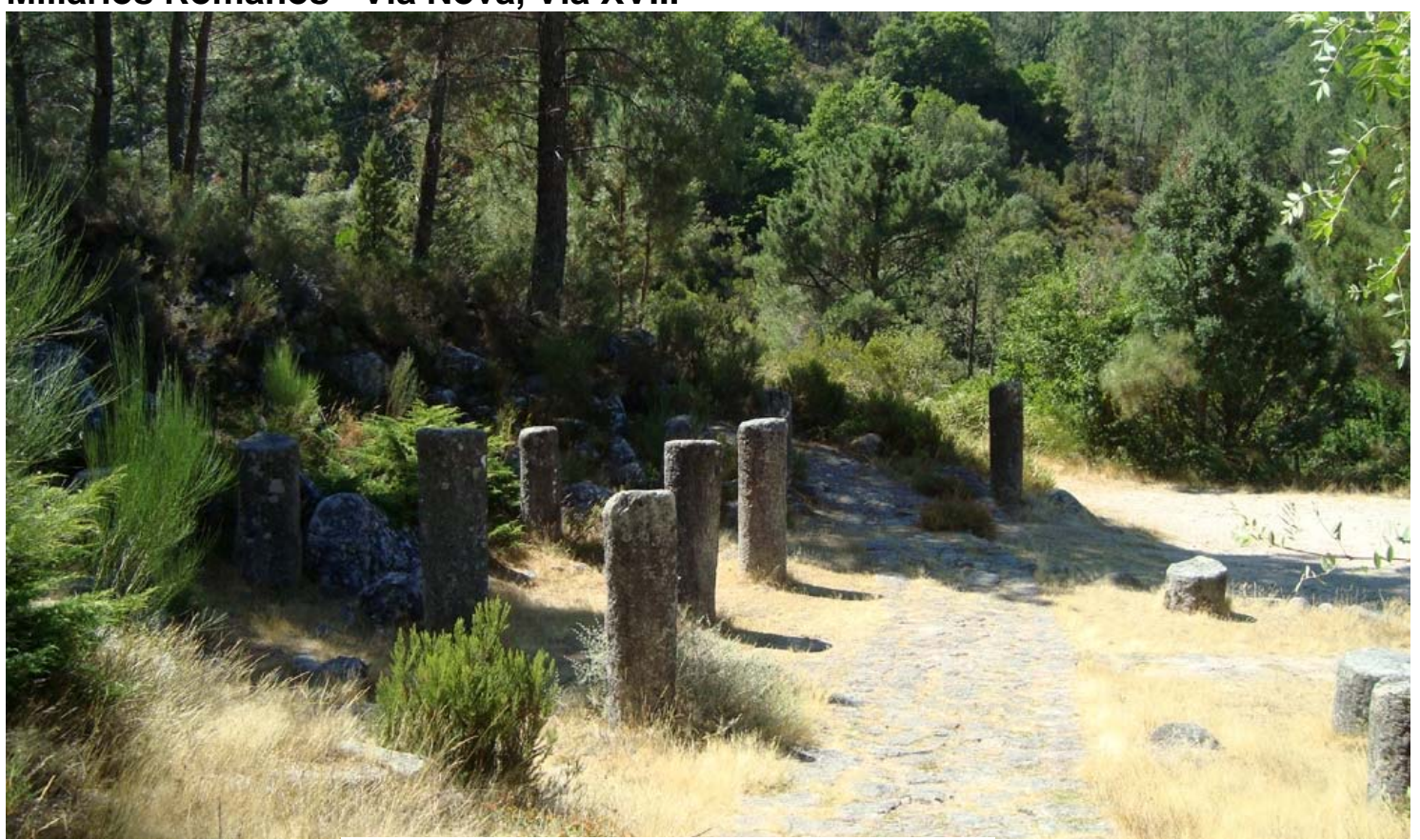

Fonte: E. C. C. da Silva (traçado da Via XVIII, na Serra do Gerêz, Portugal, agos.2013)

Os itinerários principais são conhecidos fundamentalmente por três fontes: o Itinerário de Antonino, o Anônimo de Ravena e as tábuas de Artorga (Itinerário de Barro). O primeiro dos itinerários mencionados, apesar de parcial, aparece como o mais verídico e explícito, segundo confirmação de miliários para o mesmo âmbito, resultando os outros dois como complementares daquele (RODRÍGUEZ COLMENERO; FERRER SIERRA; ÁLVAREZ ASOREY, 2004: 21).

\subsubsection{O Itinerário de Antonino}

O Itinerário de Antonino (Itinerarium Provinciarum Antonini Augusti), "o máis preciso dos conservados no que respecta á enumeración de vías e mansións" (RODRÍGUEZ COLMENERO; FERRER SIERRA; ÁLVAREZ ASOREY, 2004: 16), é o documento mais importante para o estudo das vias ${ }^{62}$ romanas. Descreve 372 itinerários terrestres, dos quais 34 circunscrevem total ou parcialmente sua rota pela Hispânia.

Trata-se de uma compilação dos principais itinerários romanos redigida, provavelmente, nos finais do século III que indica a sequência de estações viárias ou mansiones ao longo desses itinerários, bem como, as distâncias entre essas estações. As distâncias terrestres entre cada mansio são apresentadas em milhas romanas ou milla passum ( $\mathrm{mpm})^{63}$. Assim, apesar dos diversos problemas que possui, constitui um amplo quadro do antigo sistema viário romano e uma fonte importante para a identificação do percurso das vias romanas.

\footnotetext{
62 Via pode ser compreendida como todo o caminho na rota da antiga via romana, seja em terra batida, calçada em pedra ou por estrada moderna.

63 milla passum (mpm), mil passos, milha romana: milia, aproximadamente $1.478,50 \mathrm{~m}$.
} 
O seu estudo tem levantado diversas discussões sobre a exatidão das estações viárias e distâncias mencionadas, sendo provável que os copistas medievais tenham cometido alguns erros na sua transcrição ou até introduzido correções segundo as suas próprias interpretações. Dessa forma, existem publicações dos itinerários com significativas diferenças que espelham essas dúvidas. A edição mais conhecida do itinerário foi publicada em Berlim, em 1848, por Gustav Parthey e Moritz Pinder com o título Itinerarium Antonini Augusti et Hierosolymitanum. Posteriormente, em 1929, foi publicada por Otto Cuntz, em Stuttgart, o Itineraria Romana. vol. I: Itineraria Antonini Augusti et Burdigalense, que é a versão mais utilizada atualmente.

O itinerário apresenta uma sequência de mansiones, ou seja, apenas as estações viárias (locais de descanso) nas quais existiam estalagens, aparentemente omitindo as mutationes que certamente existiam ao longo do seu percurso. Essas mansiones localizavam-se na periferia da via para dar apoio aos viajantes, estando localizadas não só nas grandes civitates como, também, em lugares pouco povoados que herdavam o nome que algum povoado ali próximo, um vici ou castella, tornando muito difícil a sua identificação no terreno. Algumas mansiones fazem referência ao nome do próprio rio ou a ponte romana que o atravessava.

As diversas pesquisas já realizadas permitem dizer que, no geral, os itinerários apresentam uma grande precisão, principalmente a partir do momento que se começa a entender os equívocos induzidos pela cópia medieval e posteriores reedições. A obra de síntese sobre as fontes literárias das antigas vias de comunicação na Hispânia publicada por José Manuel Roldán Hervás (1975), baseada na de Cuntz (1929), foi um marco para os estudos dessa natureza, tornando-se em uma das monografias mais citadas nos estudos referentes a rede viária da Hispânia.

Outro aspecto essencial na renovação desses estudos foi a iniciativa de Gonzalo Arias Bonet através da publicação da revista El Miliario Extravagante, que trouxe uma nova visão sobre o Itinerario de Antonino, assim como dos caminhos de época romana na Península Ibérica. Esse autor insistiu na consideração que o Itinerario de Antonino não constituía um guia de caminhos, mas uma compilação de trajetos, na qual muitas vias de maior importância teriam ficado fora (1987).

Arias Bonet forneceu um modelo de interpretação, através da análise dos casos gramaticais no Itinerário de Antonino (1993, vol. 1, p. 69-77; 2000: 267-280). A partir de sua "interpretação gramatical" do Itinerário Arias defendeu que quando as mansiones apareciam em acusativo no texto não se encontravam, na realidade, junto a uma calçada ou via, mas a uma certa distância a partir da existência de um ramal (diverticulum) da calçada que a liga (nesse sentido a preposição $A d)^{64}$.

Essa teoria explicaria as diferenças nas distâncias expressadas em algumas ocasiões, já que em algumas delas não seriam simples erros de transcrição dos copistas. Contudo, Roldán Hervás (1966; 2014: 31-32) alertou sobre essa interpretação:

(...) no pasa, sin embargo, de ser una hipótesis que sólo la absoluta confirmación arqueológica puede llegar a resolver, ya que en los casos estudiados por su autor también se producen algunas excepciones".

\footnotetext{
${ }^{64}$ Denominada "teoría de los empalmes" (ARIAS BONET, 2008: 78-83).
} 
Para o Noroeste Peninsular, no que diz respeito a comunicação entre as três capitais conventuais - Bracara Augusta, Lucus Augusti e Asturica Augusta, dispomos da descrição de quatro vias principais: Via XVII, Via XVIII, Via XIX e Via XX. A Figura 4.1.1.a apresenta as vias do Itinerário de Antonino no Noroeste Peninsular segundo o traçado proposto por Roldán Hervás (1975).

Figura 4.1.1.a

Vias do Itinerário de Antonino no Noroeste Peninsular propostas por Roldán Hervás (1975)

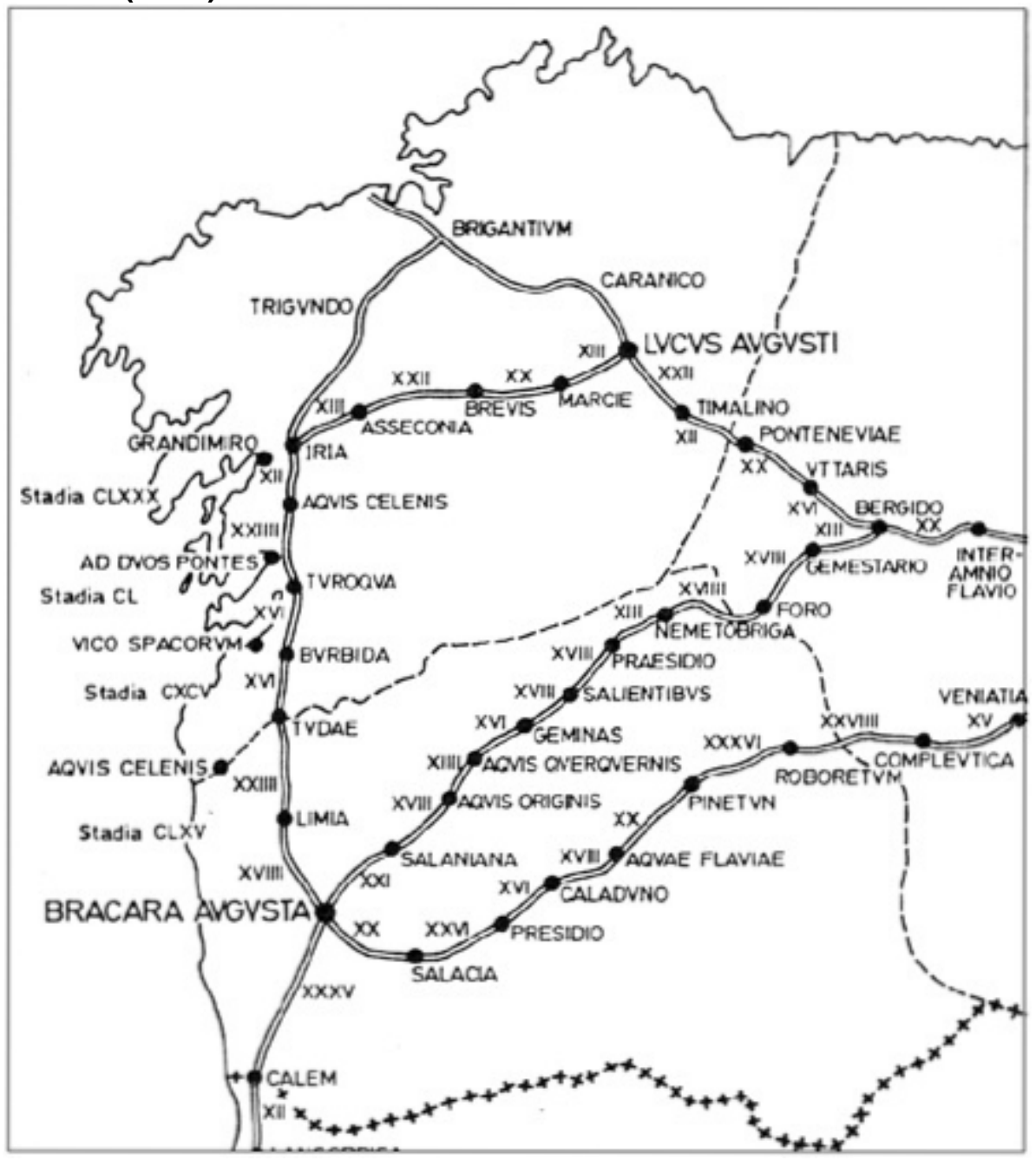

Fonte: Roldán Hervás (1975)

\section{- Via XVII (item a Bracara Asturicam)}

A via XVII aparece documentada no Itinerário de Antonino e nas tábuas de Astorga, ou Itinerário de Barro. O traçado do Itinerário da 'Tabula IV' do Itinerário de Barro (topônimos da própria tábua), coincide em boa parte com o traçado da Via XVII do Itinerário de Antonino. Provavelmente, trata-se de uma via militar do tempo da conquista (FERNANDEZ OCHOA et al., 2012).

Permitia a ligação entre Bracara Augusta e Asturica Augusta, num percurso que atravessava o atual Norte de Portugal até Aquae Flaviae (Chaves), dobrando para 
nordeste por Veniatia, Petavonium, Argentiolum e Asturica (LEMOS, 1993, 2000, 2002c; LEMOS e MORAIS, 2004; FERNÁNDEZ OCHOA, 1995).

É a calçada mais meridional das existentes entre Bracara Augusta e Asturica Augusta; e a mais antiga do Noroeste Peninsular devido aos vários miliários atribuídos a Augusto datados entre os anos 5 e 2 a. C. Essa via, ao longo de todo o seu âmbito e extensão, nunca foi estudada de maneira aprofundada existindo apenas contribuições setoriais mais ou menos válidas.

Ao longo dessa via as mansiones seguramente conhecidas, além de Bracara e Asturica Augusta, são: Aquae Flaviae (Chaves), e Petavonium (Ciudadeja, Rosinos de Vidriales). Quanto as demais, podem ser relacionadas Pinetum e Compleutica, e com bastantes problemas Salacia, Praesidium, Caladunum, Reboretum e Argentiolum (RODRÍGUEZ COLMENERO; FERRER SIERRA; ÁLVAREZ ASOREY, 2004: 122).

A seguir está a sucessão de mansiones da Via XVII, segundo Cuntz (1929: 65).

\begin{tabular}{ll}
\multicolumn{1}{c}{17} & \\
2 Item a Bracara & \\
Asturicam & m. p. CCXLVII: \\
3 Salacia & m. p.XX \\
4 Praesidio & m. p. XXVI \\
5 Caladuno & m. p. XVI \\
6 Ad Aquas & m. p. XVIII \\
7 Pinetum & m. p. XX \\
8 Roboretum & m. p.XXXVI \\
423. 1 Compleutica & m. p.XXVIII \\
2 Veniatia & m.p.XV \\
3 Petavonium & m. p.XXVIII \\
4 Argentiolum & m. p.XV \\
5 Asturica & m. p.XXIIII.
\end{tabular}

A Figura 4.1.1.b, apresenta o traçado provável da Via XVII relacionado com as capita viarum - Bracara ou Asturica - e com a mansio intermedia - Aquae Flaviae ${ }^{65}$.

65 A metodologia utilizada para a elaboração dos traçados é apresentada no item 4.2 Procedimentos Metodológicos. 
Figura 4.1.1.b

Via XVII (item a Bracara Asturicam)

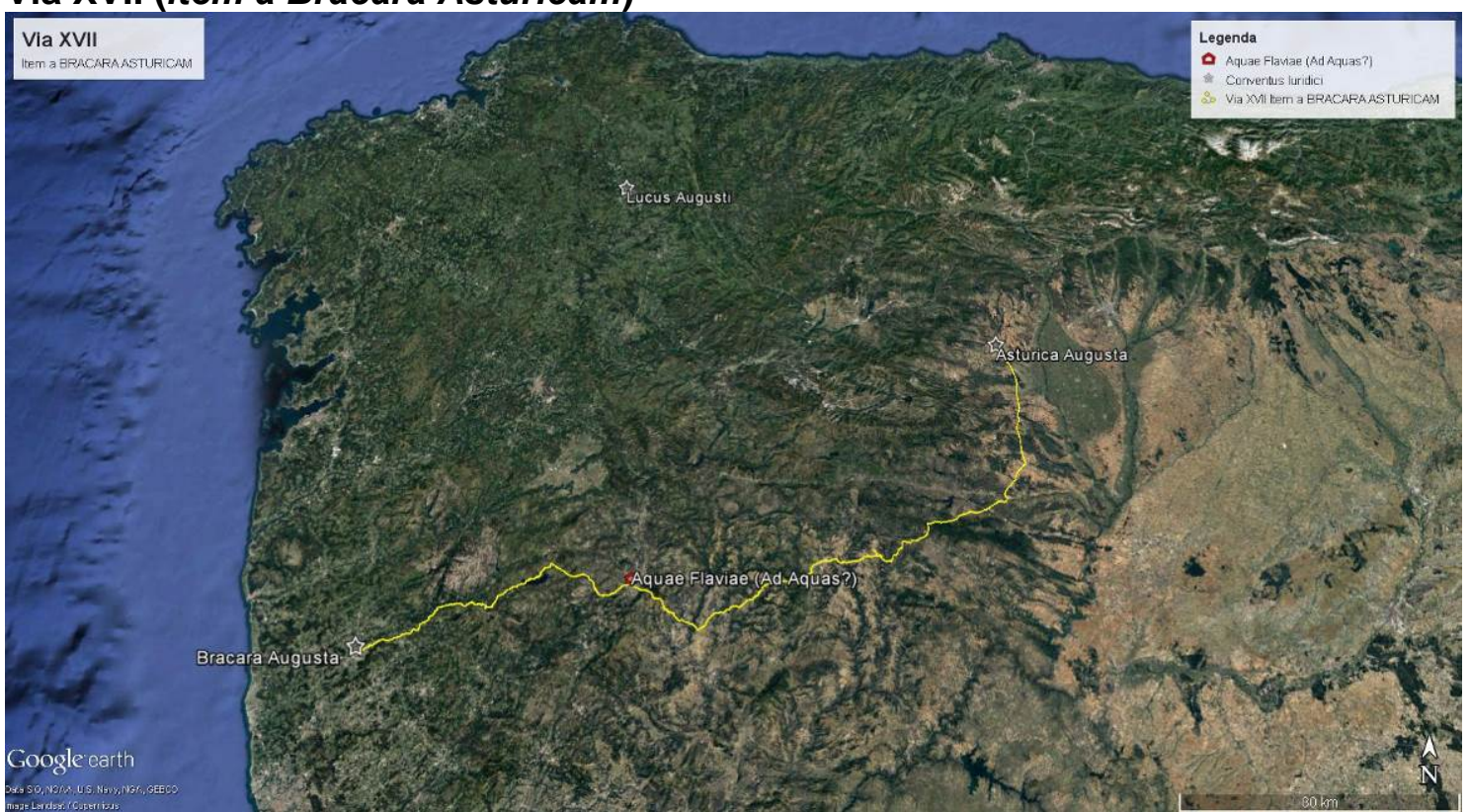

Fonte: E. C. C. da Silva (2016), base Google Earth Pro ${ }^{\circledR}$

\section{- Via XVIII ou Via Nova (Item alio itinere a Bracara Asturicam)}

Aberta entre Bracara e Asturica, pelo interior montanhoso do território AsturGalaico no tempo dos Flávios, oferece a maior densidade de monumentos epigráficos viários entre toda as vias do império. Essa via ligava Asturica com a região aurífera de El Bierzo.

Treze milhas a leste de Gemestario, Bergidum Flavium, citada por diversas fontes da época, constitui um importante epicentro viário no qual confluíram, pelo menos, duas vias importantes do Itinerário de Antonino: a XIX e a XVIII. Sabe-se que o núcleo primitivo estava assentado sobre o Castro Ventosa, estrategicamente situado, e caput civitatis dos Bergidenses (RODRÍGUEZ COLMENERO; FERRER SIERRA; ÁLVAREZ ASOREY, 2004: 375).

A seguir está a sucessão de mansiones da Via XVIII, segundo Cuntz (1929: 65). 


\section{8}

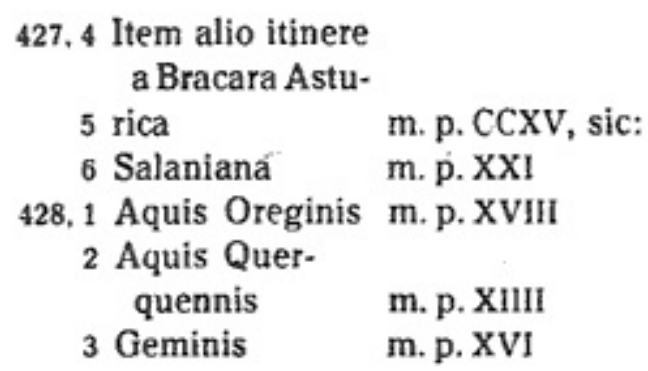

\begin{tabular}{|c|c|c|}
\hline 920 & Salientibus & m.p. XVIII \\
\hline & Praesidio & m. p.XVIII \\
\hline & Nemetobrica & m. p. XIII \\
\hline & Foro & m.p.XVIII \\
\hline 429. & Gemestario & m. p. XVIII \\
\hline & $\begin{array}{l}\text { Belgido } \\
\text { Intereraconio }\end{array}$ & m. p. XIII \\
\hline & Flavio & m. p. XX \\
\hline & Asturica & m. p. XXX. \\
\hline
\end{tabular}

A Figura 4.1.1.c, abaixo, apresenta o traçado provável da Via XVIII relacionado com as capita viarum - Bracara ou Asturica - e com a mansio intermedia - Bergidum Flavium ${ }^{66}$.

Figura 4.1.1.c

Via XVIII (Item alio itinere a Bracara Asturicam)

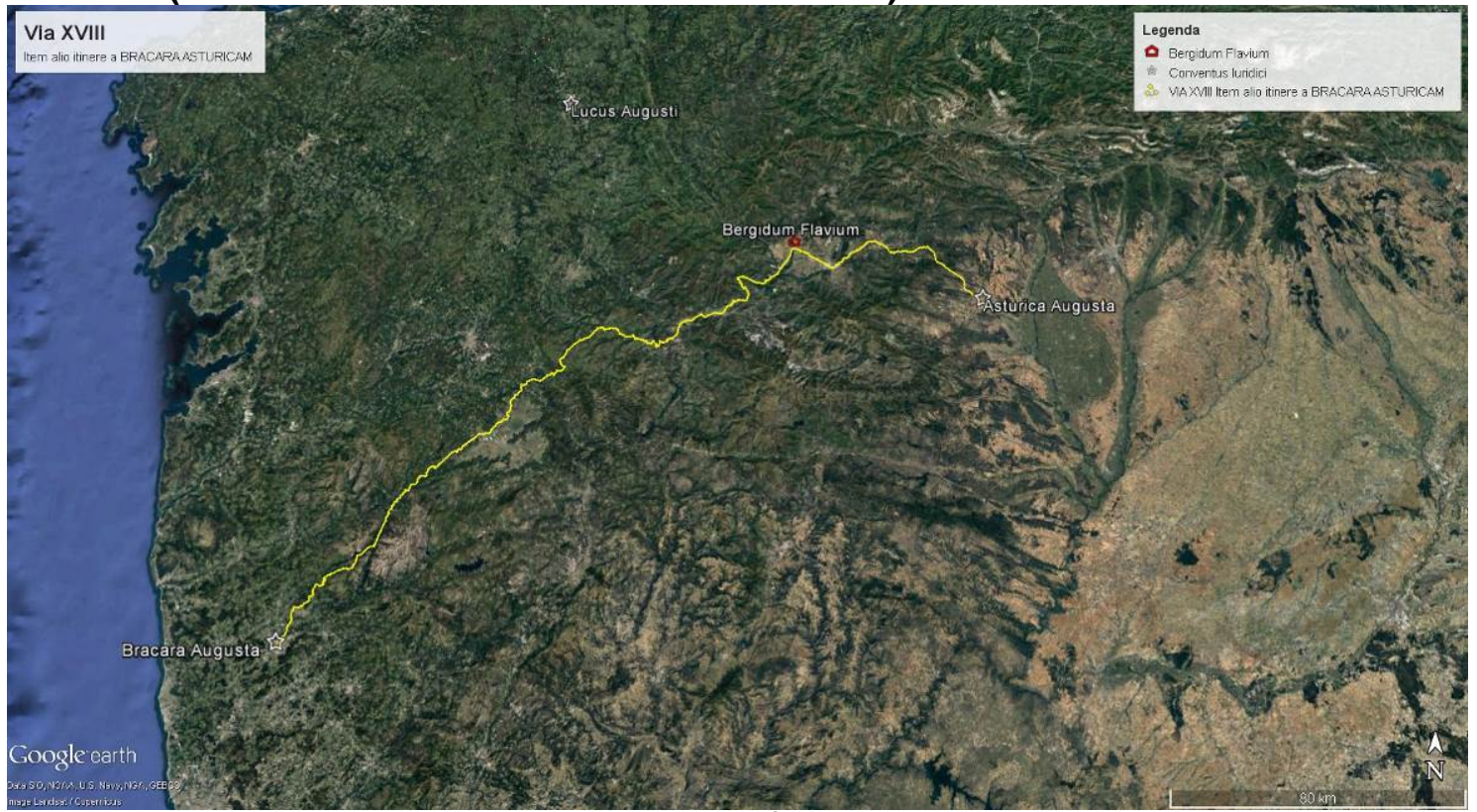

Fonte: E. C. C. da Silva (2016), base Google Earth Pro ${ }^{\circledR}$

66 A metodologia utilizada para a elaboração dos traçados é apresentada no item 4.2 Procedimentos Metodológicos. 


\section{- Via XIX (item a Bracara Asturica)}

A Via XIX (item a Bracara Asturica) ligava Bracara a Asturica por Lucus Augusti. Saindo de Bracara Augusta, este percurso passava por Limia (Ponte de Lima), seguindo desta mansio para norte até atingir Tude (Tuy), depois de passado o rio Minho. A partir da mansio de Tude avançaria direção norte através da depressão meridiana, percorrendo uma das duas ribeiras do rio Louro. Daí a via seguia para Iria Flavia e dobrava para leste em direção a Lucus Augusti. Dessa cidade arrancava o percurso de ligação a Asturica (ALMEIDA, 1968; ALMEIDA, 1979; PÉREZ LOSADA, 2002; FERNÁNDEZ OCHOA, 1995).

A seguir está a sucessão de mansiones da Via XIX, segundo Cuntz (1929: 65).

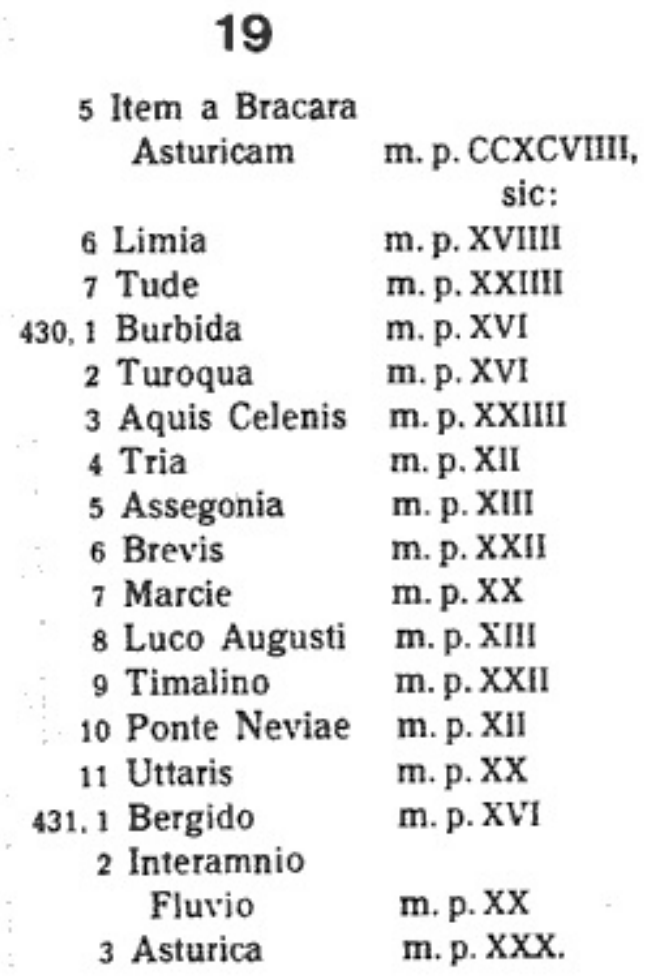

A Figura 4.1.1.d, abaixo, apresenta o traçado provável da Via XIX relacionado com as capita viarum - Bracara, Lucus e Asturica. ${ }^{67}$.

67 A metodologia utilizada para a elaboração dos traçados é apresentada no item 4.2 Procedimentos Metodológicos. 
Figura 4.1.1.d

Via XIX (item a Bracara Asturica)

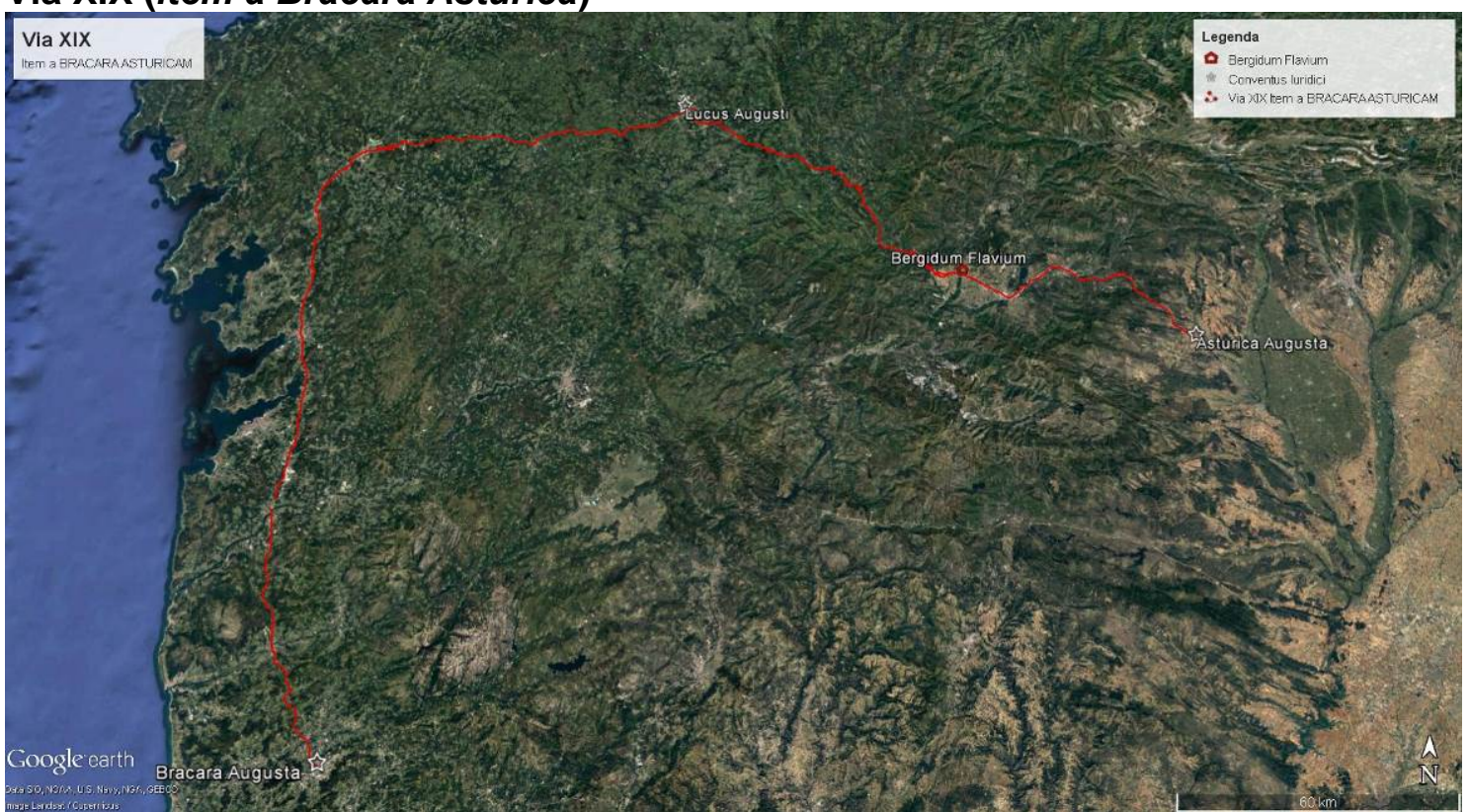

Fonte: E. C. C. da Silva (2016), base Google Earth Pro ${ }^{\circledR}$

\section{- Via XX (item per loca maritima a Bracara)}

A Via XX (item per loca maritima a Bracara) unia Bracara a Asturica num percurso que deveria percorrer a orla marítima, pondo em relação Brigantium (A Coruña) com Asturica Augusta. A cronologia desta via é desconhecida, devido à ausência de miliários, sendo o seu trajeto controverso. A maioria dos autores considera que o seu traçado no território português, entre Bracara e Tude (Tuy), seria coincidente com o da via XIX, seguindo a partir daí por um traçado litoral que acompanhava os recortes da costa galega até Brigantium. Têm sido sugeridas outras hipóteses de trajeto para esta via.

Para Rodríguez Colmenero; Ferrer Sierra; Álvarez Asorey (2004: 591) "a vía per loca maritima entre Bracara e Asturica, en realidade, resulta unha fraude, xa que de marítima non ten máis có tramo correspondente a dúas mansións".

A seguir está a sucessão de mansiones da Via XX, segundo Cuntz (1929: 66). 


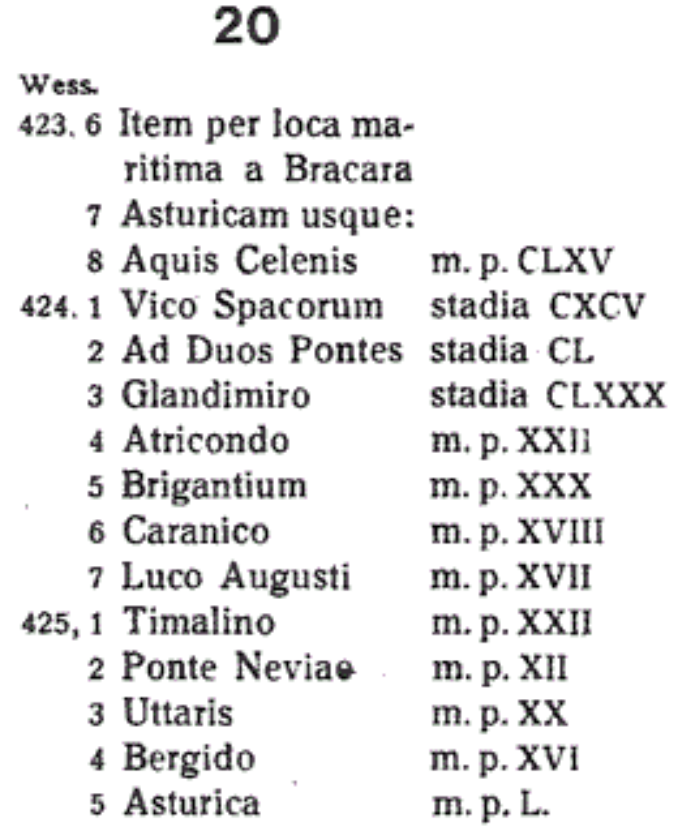

Além dessa rede de itinerários principais, o sistema viário integrava itinerários secundários e viae vicinales e privatae, compondo uma complexa hierarquia de caminhos. O horizonte descritivo dessas redes, devido à sua densidade e às suas especiais e difíceis condições de aferição espacial, não será aqui abordado.

A rede de vias secundárias (Viae Vicinales) é, por natureza, muito difícil de identificar. As vias secundárias não possuem miliários e tinham menor investimento na sua construção, o que contribuiu para o seu mais rápido desaparecimento. No entanto, alguns trabalhos de análise territorial em âmbitos geográficos mais restritos têm permitido conhecer algumas dessas vias.

Com relação as revisões técnicas ou construtivas, a participação de engenheiros tem permitido revisar problemas importantes tanto de construção como de traçado nas vias romanas existentes no território espanhol, como, por exemplo, o estudo de Isaac Moreno Gallo sobre as características técnicas da calçada romana na Meseta Norte que ligava Caesaraugusta com a Legio VII (MORENO GALLO, 2002, vol. 1, p. 87116).

\subsection{Procedimentos Metodológicos}

Os estudos arqueológicos se fundamentam na investigação territorial de padrões de ocupação. No presente estudo, no entendimento do padrão de rotas estabelecido pelos romanos no Noroeste da Península Ibérica, se investiga as evidências materiais ainda persistentes na paisagem, o padrão da cobertura vegetal e do relevo, além da própria hidrografia regional. Tais características demonstram uma miríade de fatores de cunho geográfico essenciais para o entendimento das paisagens estudadas. De modo a favorecer o entendimento de fatores tão complexo dentro da paisagem, os Sistemas de Informação Geográfica (SIG) vem se tornando ferramenta indispensável. 
De acordo com López Romero (2005: 97), o uso de Sistemas de Informação Geográfica (SIG) em trabalhos arqueológicos tem aumentado substancialmente. Desde a publicação dos trabalhos de Allen, Green e Zubrow (1990), vem se desenvolvendo metodologias que visam padronizar a maneira de como a informação geográfica deve estar organizada em estudos arqueológicos. No caso da Europa, os trabalhos arqueológicos que se utilizam de SIG tem contribuído ao inventariamento do patrimônio arqueológico das áreas urbanas de cidades históricas.

Embora a utilização de SIG como ferramenta de apoio aos trabalhos arqueológicos tenha ganhado fôlego, a incorporação das técnicas em SIG tem se concentrado em alguns temas como cálculos utilizando Polígonos de Thiessen, cálculos de medidas e distâncias a recursos estratégicos, entre outros. No entanto, na ultima década o desenvolvimento de cálculos de rotas ótimas tem se tornado útil para o conhecimento de vias de comunicação existentes por meio do estabelecimento de períodos cronológicos precisos.

O principal problema encontrado nos estudos de rotas ótimas é a análise dos caminhos de grupos humanos pré-históricos, sobretudo onde a topografia oferece múltiplas possibilidades de caminhos. A dificuldade de se encontrar documentos históricos que respaldem os caminhos estabelecidos por povos antigos torna como uma das únicas hipóteses para o estabelecimento das rotas os caminhos naturais como rotas preferenciais de uso ao longo da história. Deixa-se, portanto, de se utilizar fatores sociais como condicionantes ao estabelecimento das rotas e passa-se a considerar atributos naturais no lugar dos elementos culturais, tornando, portanto, 0 estudo das rotas de povos antigos ainda algo hipotético. Para continuar avançando, os estudos de rotas ótimas necessitarão de uma forte base empírica para comprovação dos resultados.

López Romero (2005: 98) ressalta que os cálculos de rotas ótimas se baseiam em sistemas de informação geográfica que permitem cálculos de valores acumulativos de diferentes pixels dentro de um arquivo raster. A modelagem resultante no arquivo raster representará o custo ou dificuldade de deslocamento em um dado território, de modo que é possível solicitar ao programa que determine o caminho por meio da união de pontos nos pixels com indicação dos menores valores, que são nada mais que a definição da superfície de menor custo. Os resultados a serem obtidos, segundo os autores, dependerá em grande medida das variáveis a serem usadas na modelagem raster, o que permitirá a definição da rota de menor custo.

Para alguns os autores, o relevo e a topografia são os fatores naturais mais relevantes na determinação de rotas de menor custo (rotas ótimas) (BERMÚDEZ SÁNCHEZ, 2004; FAIRÉN JIMÉNEZ, 2004), aparecendo também, os cursos d'água, os tipos de solos e a vegetação. No entanto, esses dados são bastante genéricos e a ausência de indicadores culturais não permite uma reconstituição fiel dos ambientes encontrados por determinado agrupamento humano durante o período em que os mesmos perfaziam suas rotas.

O objetivo desse trabalho é demonstrar, a partir do estudo das relações entre redes de caminhos, povoamento e território, uma abordagem experimental através da utilização de ferramentas geotecnológicas na pesquisa arqueológica, o qual propomos um exemplo metodológico de aplicação de diferentes variáveis para o cálculo de rotas ótimas para o território do Noroeste Peninsular. 
A seleção de parâmetros para a elaboração de um cálculo de rotas ótimas é um tema determinante porque os resultados finais a serem obtidos dependem, em grande parte, deles. Podemos dividir, por sua natureza, os fatores ambientais, principalmente o relevo do terreno, e, também, incluir outras como, por exemplo, a hidrografia, os tipos de solo ou a vegetação. Entretanto, todos esses fatores apresentam o inconveniente de se trabalhar, geralmente, com dados atuais e muito gerais, já que é muito difícil o acesso a dados paleomabientais precisos.

Outro grupo de variáveis são as culturais, tais como as fronteiras políticas, existência de caminhos ou pontes anteriores que poderiam ter sido utilizados. E determinados elementos ou pontos do território que motivassem a aproximação, ou até mesmo o desvio, pelo fato de terem um significado social ou ritual adicionado (LLOBERA, 1999).

Em nossa proposta metodológica utilizamos duas variáveis naturais: o relevo (índice de pendência) e os cursos de água. Dessas variáveis, a única indispensável é o relevo. Como demonstrado em alguns trabalhos (BERMÚDEZ SÁNCHEZ, 2004; FAIRÉN JIMÉNEZ, 2004; VICENTE GONZÁLEZ, 2012), a orografia é o fator mais importante para o cáculo de rotas ótimas de um território, haja vista que de todas as formas são as topográficas que substancialmente condicionan e determinam os traçados viários. Contudo, não se pode omitir que os dados de relevo utilizados são da orografia atual, a qual sofreu importantes mudanças no decorrer do tempo. Dessa forma, os resultados obtidos são indicativos.

Para a variável de relevo é necessário a construção de um Modelo Digital de Terreno. Esse é obtido a partir de curvas de nível, que são transformadas em uma malha de céluas contínuas em que cada uma contém informação de irregularidade do terreno, ou seja, a altura.

Com relação aos parâmetros culturais, buscamos identificar os sinais de "Romanidade". E como esses sinais podem ser identificados? Os romanos não utlizavam habitualmente caminhos estreitos e com grandes declives. Isso só ocorria para ultrapassar obstáculos como, por exemplo, de rios em trechos de montanha. Algumas características que mostram que a origem do traçado é romana podem ser observadas como um alinhamento perfeito, curvas com arcos de curvatura corretas, uma utilização sutil dos próprios acidentes de terreno (como pedras), em resumo, características que demonstram a utilização de matemática e instrumentos de medida de precisão na sua construção, marcas incontestavelmente romanas.

Segundo Solana Sáinz \& Sagredo San Eustaquio (2006: 21), os princípios que regulavam as dimensões de cada tipo de via, de acordo com o jurista Gaius ${ }^{68}$, deviam ter em conta uma largura de 8 pés $^{69}(=2,24 \mathrm{~m})$ em sua parte reta e 16 pés $(=4,48 \mathrm{~m})$ nas curvas.

De acordo com R. Chevalier (1972: 69), em época augústea, os eixos das centurias teriam as seguintes medidas: o decumanus maximus teria 40 pés $(=11,20 \mathrm{~m})$ e o kardus maximus teria 20 pés $(=5,60 \mathrm{~m})$. Os eixos menores teriam 8 pés $(=2,24 \mathrm{~m})$.

Temos que pensar que se trata de vias romanas de 6 a 10 metros de largura destinadas ao trânsito de carroças com uma elaboração cuidadosa incluindo valas de

${ }^{68}$ Digesto, VIII, 3, 8 (tabla VII).
${ }^{69}$ A medida do pé é $0,28 \mathrm{~m}$. 
drenagem, valores de pendente suave (atualmente o máximo recomendado é $8 \%$; provavelmente em época romana não diferisse muito já que preferiam alongar o traçado) feitas com cantos e buscando sempre, no caso de montanhas, as encostas mais acessíveis e ensolaradas.

O que Roma fornece são traçados mais amplos e encaixados em um curso mais racional, pavimentos mais acessíveis, pontes e outros meios para superar as canais fluviais e estações viárias ou locais de descanso (mansiones), estrategicamente localizadas, para permitir o descanso nos percursos de longa distância. Também não podemos esquecer das sinalizações como, por exemplo, os miliários. Este são fontes históricas e arqueológicas fundamentais (ENCARNAÇÃO, 2011: 385-394).

Não há dúvidas de que o fator determinante ao transcorrer uma via romana deve levar em conta os miliários como critério essencial, especialmente quando estão relacionados com capita viarum, no caso Bracara Augusta, Lucus Augusti ou Asturica Augusta, ou com uma das importantes mansiones intermediárias, como Aquae Flaviae e Bergidum Flavium. Os miliários iam além de uma mera indicação de milha, também funcionavam como propaganda imperial.

A seguir, descreveremos o como foi elaborado o cálculo de caminho ótimo no projeto de Sistema de Informação Geográfica utilizado em nossa pesquisa.

\subsubsection{Descrição do projeto SIG: Cálculo de caminhos ótimos}

\section{- Software:}

O software utilizado para realizar nosso estudo, iniciado em 2011, foi a versão 10.1 do software ArcGiS ${ }^{\circledR}$, com suas extensões 3D Analyst e Spatial Analyst. Essas extensões são direcionadas para a elaboração de Modelos Digitais de Elevação (MDE) e suas derivações como, por exemplo, mapas de pendências, mapas hipsométricos, modelos de visualização 3D etc., bem como para outras informações em formato raster.

Utilizou-se o comando Cost Distance e Cost Path para o cálculo da rota de menor custo, tendo como ponderação o Mapa de Rugosidades de Relevo e da hidrografia, feito por meio da ferramenta Weighted Overlay.

\section{- Informação em formato vetorial:}

\section{- Cartografia Básica Territorial}

A base cartográfica abrange o Noroeste da península Ibérica, ou seja, trata-se de uma área de fronteira entre dois países: Portugal e Espanha. Esse fator ocasionou algumas dificuldades na aquisição de material cartográfico. Enquanto que para o território espanhol temos uma diversidade enorme de material disponível para ser descarregado gratuitamente através do site do Centro Nacional de Información Geográfica (https://www.cnig.es/); em território português a disponibilidade é bem mais limitada, apesar de também existir uma página do Sistema Nacional de Informação 
Geográfica (http://snig.dgterritorio.pt) para descarregar arquivos. A primeira problemática se deu a respeito sobre a utilização de dados LiDAR, já que para o território português não tem essa possibilidade.

Para o território espanhol, a geodatabase projetada para abordar o projeto de pesquisa integra 121 folhas, em formato digital, do Mapa Topográfico Nacional a escala 1/25.000 (MTN25) correspondentes as comunidades autônomas da Galícia e de Castela e Leão, nas modalidades raster e vetorial (BCN25), além de MDT 05LiDAR.

Para o território português efetuou-se o download da Carta Administrativa Oficial de Portugal - CAOP 2016.

\section{- $\quad$ Cartografia geológica}

A informação geológica é de grande utilidade para o estudo da rede viária romana, pois constitui um apoio importante para identificar os corredores por onde transcorrem as vias, além de localizar as possíveis pedreiras utilizadas em sua construção e na edificação de infraestruturas anexas: calçadas, pontes, miliários, mansiones, villas etc.

Optou-se por descarregar a cartografia geológica elaborada pelo Instituto Geológico e Minero de España (IGME) e a Carta Geológica de Portugal na escala de 1:50.000 do Laboratório Nacional de Energia e Geologia (LNEG).

\section{- Informação em formato raster:}

\section{- Cartografía editada em formato digital}

Sobre a informação raster foram descarregadas 121 folhas, em formato digital, do Mapa Topográfico Nacional a escala 1/25.000 (MTN25) correspondentes as comunidades autônomas da Galícia e de Castela e Leão. Essas cartas foram integradas dentro de um único Raster Dataset, formato que permite sua consulta e visualização em modo contínuo. O mesmo foi realizado com a Carta Administrativa Oficial de Portugal - CAOP 2016.

\section{- Procedimento analítico para a modelagem do caminho ótimo:}

O estudo do caminho ótimo começou com a definição de um conjunto de evidências históricas e heranças materiais (parâmetros culturais) do período de ocupação romana da área de estudo, tais evidências foram classificadas como: Caput Viae (as três sedes conventuais: Bracara, Lucus e Asturica), Mansiones intermedias (Bergidum Flavium e Aquae Flaviae), Mansiones, Assentamentos Pré-Romanos (Castros), Miliarios, Pontes, Calçadas, Minas de ouro e prata.

A análise de caminho ótimo prosseguiu na seguinte ordem:

1. Definição dos principais nós (pontos nodais) de conversão do caminho dentre as evidências mapeadas;

2. Estabelecimento de uma metodologia de geoprocessamento semiautomatizada para interligação dos nós segundo um caminho ótimo (LLOBERA, 2011); 
3. Comparar os traçados resultantes com os traçados baseados no Itinerário de Antonino (Via XVII, Via XVIII e Via XIX).

O geoprocessamento do caminho ótimo foi realizado segundo variáveis do meio físico (terreno e hidrografia) e parâmetros culturais (evidênciais materiais) de "Romanidade" (FÁBREGAS ALVAREZ et al., 2006a; FÁBREGAS ALVAREZ, 2006b; FÁBREGAS ALVAREZ, 2007; MAGNIN, 2012).

\section{- Parâmetros Culturais como Variável:}

O elemento cultural é inserido na análise matemática como nó de conversão do caminho ótimo a ser traçado. Dentre as evidências mapeadas utilizou-se como elo entre os nós a localização das Caputs Viae, sendo esta a referência estática na modelagem a seguir detalhada.

\section{- Variáveis do Meio Físico:}

A principal variável do meio físico utilizada na ponderação foi a declividade do terreno. As classes de análise definidas foram; 0 a 3\%, 3 a 5\%, 5 a 8\%, 8 a 13\%, 13 a $20 \%, 20$ a $45 \%$ e acima de $45 \%$. Sendo que um caminho romano possuia inclinações de até $8 \%$, raramente ultrapassando este valor, para não inviabilizar a subida de carroças por tração animal (MORENO GALLO, 2006).

A segunda variável de ponderação utilizada foi a hidrografia, que representa uma importante barreira para transposição, geralmente evitada pelos romanos devido ao alto custo da construção de pontes.

A declividade do terreno foi gerada tendo como base o Modelo Digital do Terreno, gerado à partir do SRTM com pixel de 25 metros (SRTM otimizado), cálculouse a inclinação do terreno por meio da ferramenta Slope Surface, do ArcGis $10.1^{\circledR}$. O arquivo Raster resultante contendo a informação de declividade do terreno foi reclassificado (utilizando a ferramenta Reclassify, do ArcGis $10.1^{\circledR}$ ) em classes de declividade de interesse do estudo (0 a 3\%, 3 a 5\%, 5 a 8\%, 8 a 13\%, 13 a 20\%, 20 a $45 \%$ e acima de $45 \%$ ). A superfície com as classes de declividade redefinidas compõe a ponderação com a hidrografia (rios e formações lacustres naturais) obtida junto aos órgãos de planejamento de Portugal e Espanha, na escala 1:50000. Os dois arquivos vetorias, declividade e hidrografia, constituem as variáveis do meio físico utilizadas para o cálculo do caminho ótimo (rota de menor custo associado).

Por fim utilizou-se os comandos Cost Distance e Cost Path do software ArcGis $10.1^{\circledR}$ para o cálculo da rota de menor custo, tendo como entrada o Raster contendo a ponderação entre a declividade do terreno e a hidrografia, feito por meio da ferramenta Weighted Overlay. O arquivo Raster de ponderação gera uma superfície que apresenta em seus atributos o valor da multiplicação entre as variáveis do meio físico, tal multiplicação segue a ponderação detalhada na Tabela 4.2.1.a. Utilizando como parâmetro os pontos de origem e destino e o arquivo Raster resultante da ponderação das variáveis do meio físico, o comando Cost Distance gera uma superfície Raster com cada pixel representando um custo de deslocamento e o comando Cost Path consegue ler os pixels de menor valor e uni-los por meio de retas, resultando nos caminhos ótimos (de menor custo associado). O fluxograma de operações realizadas 
no software ArcGis $10.1^{\circledR}$, ilustrado na Figura 4.2.1.a, apresenta de forma didática a sequência de ferramentas utilizadas e operações realizadas.

Tabela 4.2.1.a

Detalhe da ponderação utilizada na sobreposição das variáveis do meio físico, utilizando a Ferramenta Weighted Overlay do software ArcGis 10.1®.

\begin{tabular}{|c|c|c|}
\hline Classes & Ponderação & Influência \\
\hline \multicolumn{3}{|c|}{ Classes de Declividade do Terreno } \\
\hline 0 a $3 \%$ & 1 & \multirow{7}{*}{$75 \%$} \\
\hline 3 a $5 \%$ & 2 & \\
\hline 5 a $8 \%$ & 3 & \\
\hline 8 a 13\% & 4 & \\
\hline 13 a $20 \%$ & 5 & \\
\hline 20 a $45 \%$ & 10 & \\
\hline$>45 \%$ & 10 & \\
\hline
\end{tabular}

Hidrografia

\begin{tabular}{l|l|l}
\hline $\begin{array}{l}\text { Rios e formaçoes } \\
\text { lacustres } \\
\text { naturais }\end{array}$ & 4 & $25 \%$ \\
\hline
\end{tabular}

Fonte: Elaboração de Ricardo Inácio Fogaroli e Elaine Cristina Carvalho da Silva (2016) 
Figura 4.2.1.a

Fluxograma de ferramentas utilizadas e operações realizadas utilizando o software ArcGis $10.1^{\circledR}$

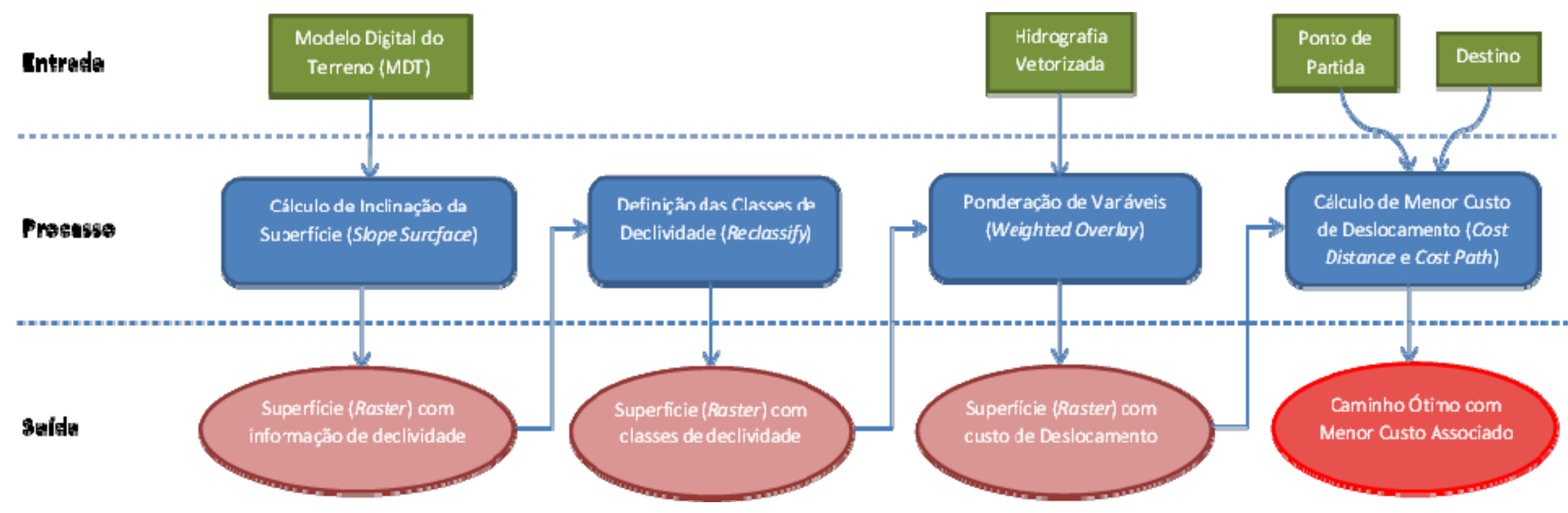

Fonte: Elaboração de Ricardo Inácio Fogaroli e Elaine Cristina Carvalho da Silva (2016) 


\section{- Outros produtos utilizados:}

Foram utilizados, como apoio, o material proveniente das seguintes bases digitais:

- Digital Atlas of the Roman Empire (http://dare.ht.lu.se/places/36185.html);

- Ancient World Mapping Center (http://awmc.unc.edu/wordpress/map-files/);

- Pleiades (www.pleiades.stoa.org);

- Traianvs - Projeto Vías Romanas in Castilla y León de Isaac Moreno Gallo (http://www.traianvs.net/viasromanas/index.php)

Além das bases digitais, também foram utilizados, como apoio, o material proveniente dos Projetos Vias Augustas e Vias Atlânticas. Os dois projetos ocorreram no âmbito do programa INTERREG III-A, que visava o estabelecimento de um itinerário turístico cultural transfronteiriço, tomando como base a valorização das vias romanas XVII, XVIII e XIX.

O Projeto Vias Atlânticas - Valorização da Via XIX: visava a o estabelecimento de um itinerário turístico cultural transfronteiriço, tomando como base a via XIX do Itinerário de Antonino. Foi realizado trabalhos de limpeza, valorização e sinalização da respetiva via, abrangendo os vários concelhos do Noroeste Peninsular. Além da supressão vegetal e limpeza, os trabalhos de acompanhamento em conjunto com as ações de prospecção, permitiram identificar novos sítios e cartografar e descrever sítios já existentes em bibliografia.

O Projeto Vias Augustas - Valorização da Via XVII: previa a recuperação e dinamização da via romana XVII do Itinerário de Antonino para fins turísticos. Além da supressão vegetal e limpeza, os trabalhos de acompanhamento em conjunto com as ações de prospecção, permitiram identificar novos sítios e cartografar e descrever sítios já existentes em bibliografia.

\subsection{Resultados das modelações dos caminhos ótimos}

De nosso ponto de vista, resulta de especial interesse o desenvolvimento de procedimentos analíticos que, como os dos caminhos ótimos, são meios para elaborar abordagens experimentais de modo a extrair de nossos dados elementos diferentes de trabalho e enriquecer as opções analíticas.

Em um primeiro momento foi realizado levantamento de campo, em junho/julho/agosto de 2013, nas cidades de Braga (Portugal), Lugo (Espanha) e Astorga (Espanha), ou seja, as três capitais conventuais - Bracara Augusta, Lucus Augusti e Asturica Augusta - fundadas por Augusto. Durante essa atividade, também foi possível percorrer o traçado da Via XVIII, na Serra do Gerêz, em território português. Neste caminhamento foi realizado o georreferenciamento de evidência 
arqueológicas conhecidas e visitáveis nas três cidades citadas, além dos trechos com evidências de calçada romana e miliários na via XVIII, "Via Nova".

Também foi realizado um levantamento bibliográfico exaustivo sobre a rede viária romana na Hispânia. Após a obtenção das informações literárias foi efetuado um levantamento de bases digitais com informações sobre as vias do império romano. Com esse levantamento foi possível agregar resultados parciais sobre os traçados da rede viária do Noroeste segundo o Itinerário de Antonino: a vias XVII, XVIII e XIX. Optou-se por excluir a análise da via XX per loca maritima porque trata-se de um trajeto controverso que seria coincidente em parte com o da via XIX, seguindo outra parte em litoral.

Os trechos das vias nos quais não foi possível obter evidências de calçadas ou de miliários, foi realizado um trabalho detalhado a procura de outros sinais de "Romanidade". Entre eles uma análise morfológica do terreno de modo a perceber certas características como a largura das vias, a declividade, evidências de pontes, miliários etc. Essa análise se somou aos outros indícios materiais (castros, minas de ouro, trechos com calçadas etc), além das informações literárias sobre as possíveis localizações das mansiones descritas no Itinerário de Antonino. O mapa geral, contendo as vias XVII, XVIII e XIX do Itinerário de Antonino, e tendo como base o Modelo Digital do Terreno, gerado à partir do SRTM, está no Anexo 1.

A seguir, serão apresentadas todas as evidências coletadas para efetuar os traçados das três vias. As Figuras 4.3.a a 4.3.e ilustram, respectivamente, as seguintes evidências espacializadas: calçadas romanas, miliários, pontes, minas de ouro e assentamentos pré-romanos. 
Figura 4.3.a

Calçadas Romanas

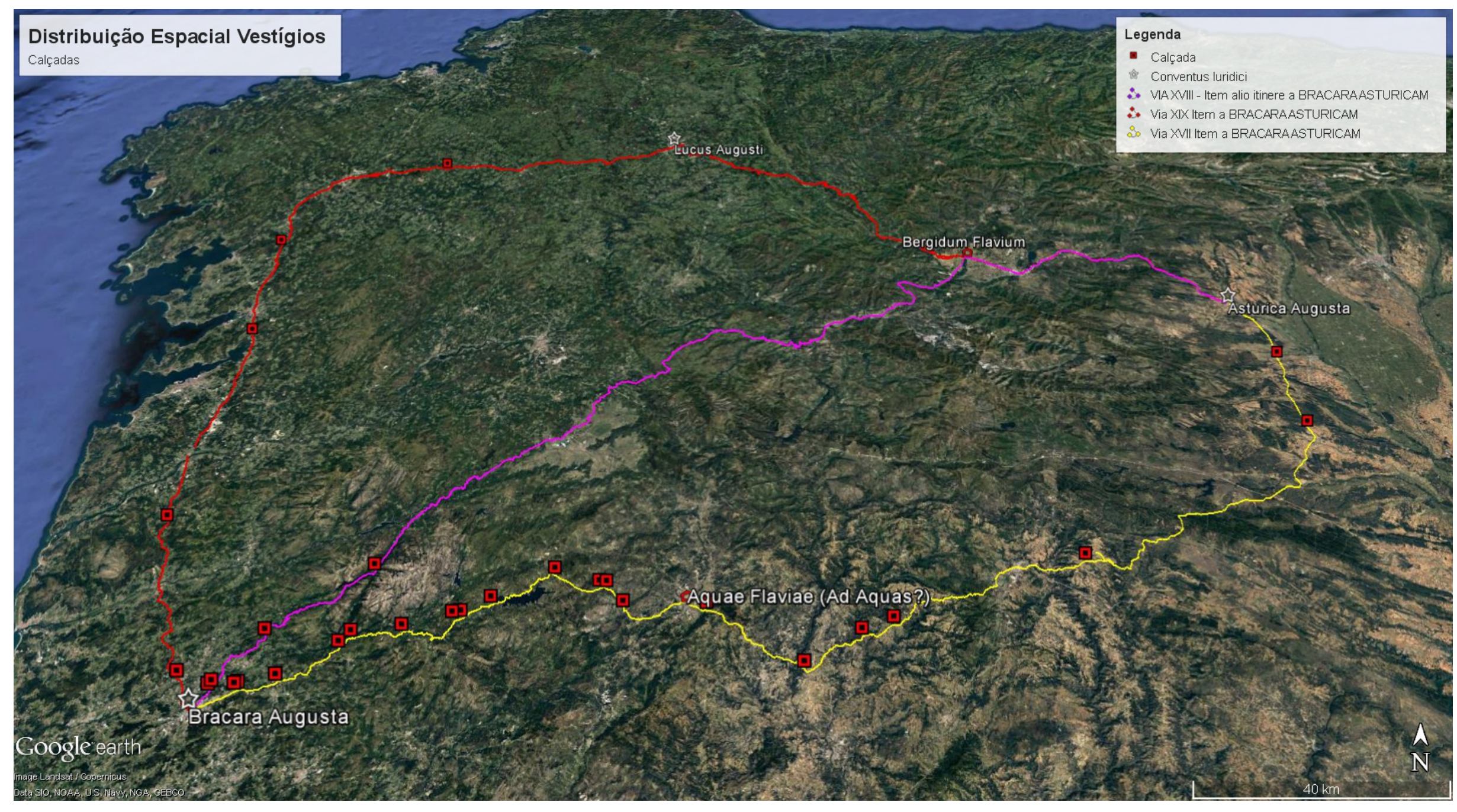


Figura 4.3.b

\section{Miliários}

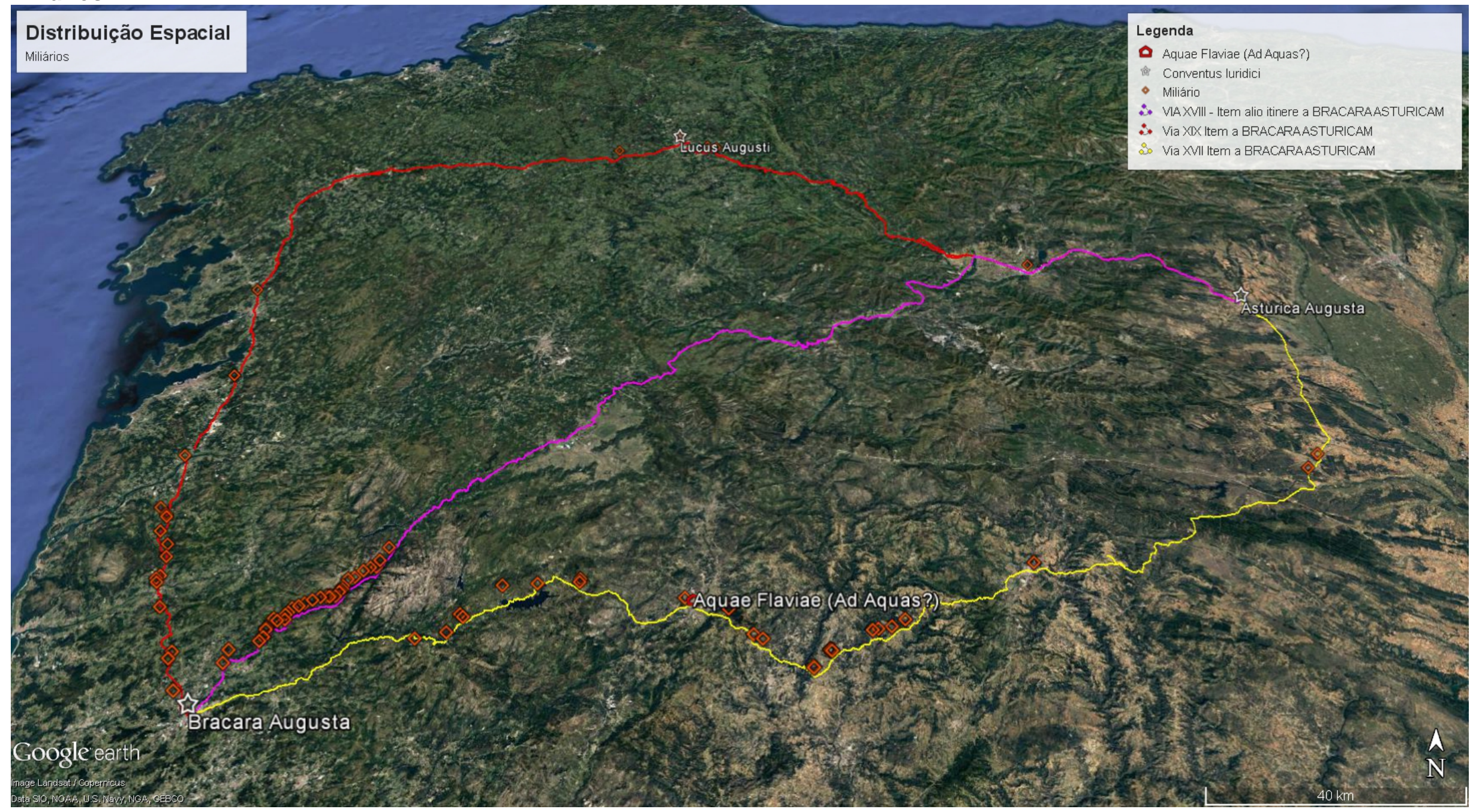




\section{Figura 4.3.c}

\section{Pontes Romanas}

Distribuição Espacial Vestígios Pontes Romanas

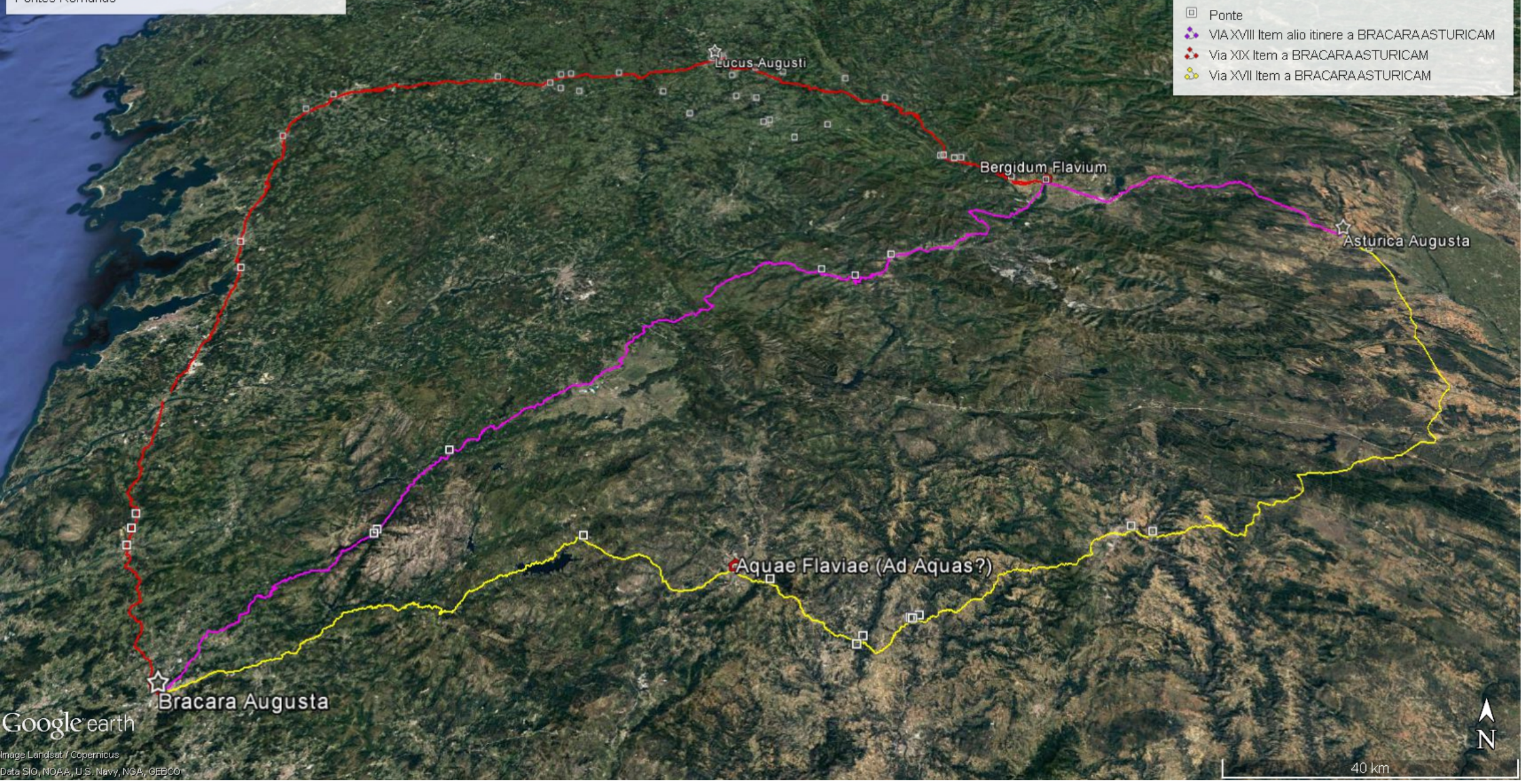


Figura 4.3.d

Minas de ouro

Distribuição Espacial

Minas de ouro

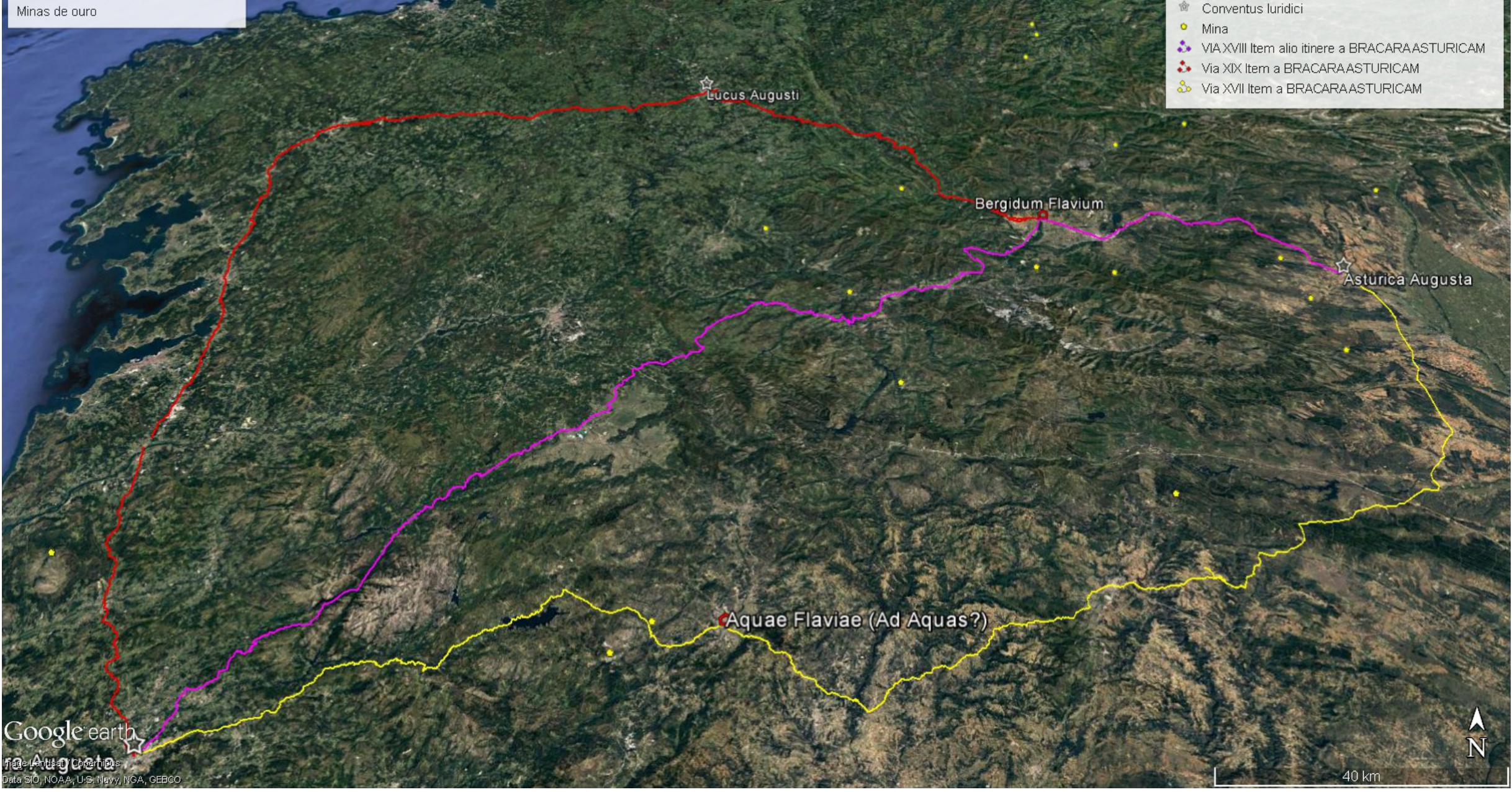




\section{Figura 4.3.e}

Assentamentos pré-romanos

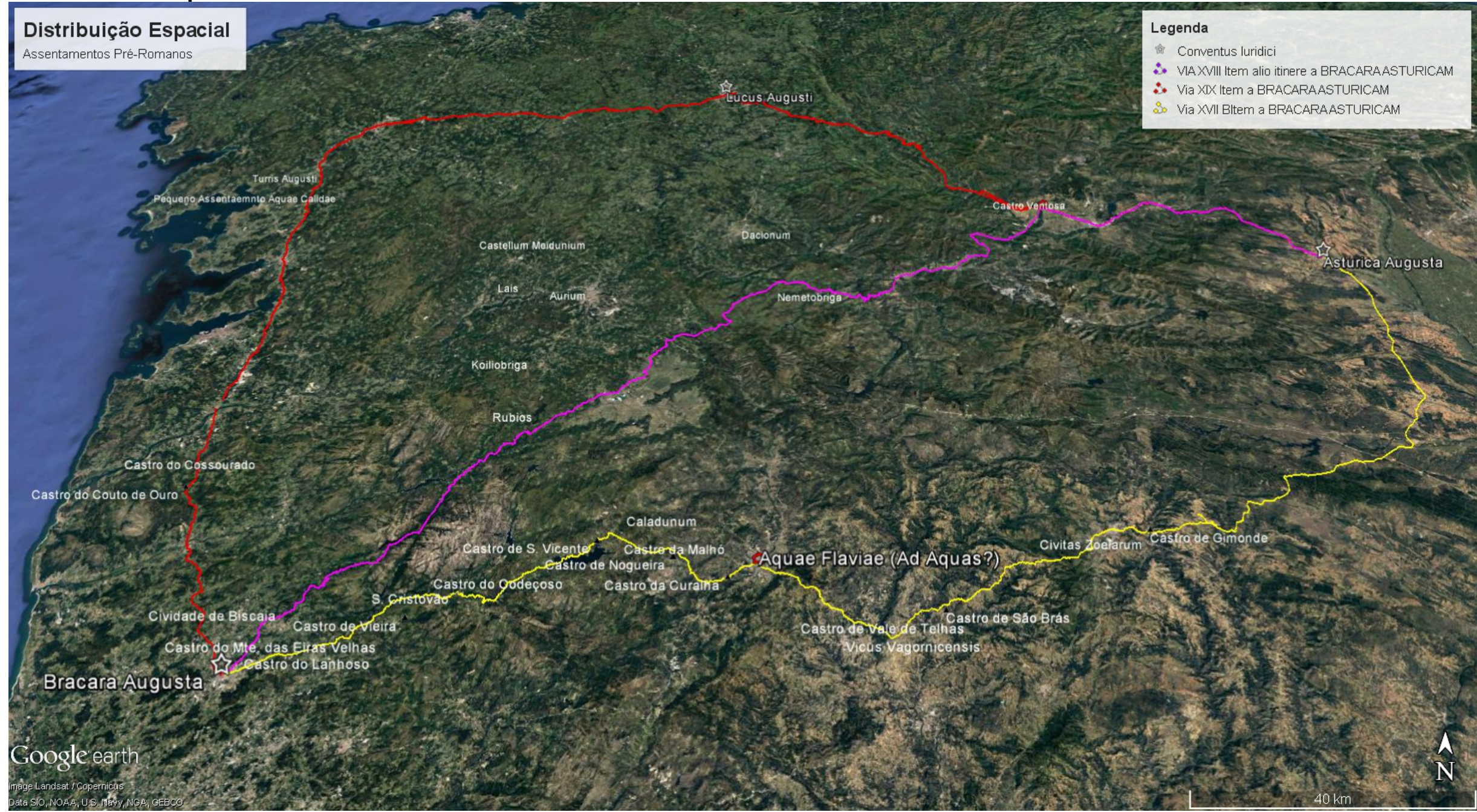


Foi a partir dessa base de evidências coletadas que se pode proceder ao cálculo de caminhos ótimos. Os procedimentos analíticos se basearam na determinação de caminhos ótimos (optmal routes) para cada uma das três vias. O ponto de partida lógico são as três capitais conventuais do Noroeste Peninsular: Bracara Augusta, Lucus Augusti e Asturica Augusta. O objetivo é comparar as análises de caminhos ótimos entre as capitais conventuais e as mansiones. Dessa forma, busca-se comparar os resultados obtidos através do cálculo dos caminhos ótimos com os traçados dos caminhos documentados, buscando convergências e divergências.

A primeira análise de cálculo de caminho ótimo foi realizada entre as mansiones. Foram incorporados os pontos históricos, marcadores culturais, relativos a possível localização das mansiones como "nós". Dessa forma, ao forçar a passagem pelos pontos (nós) dos mansios observa-se que o resultado do traçado do caminho ótimo é muito mais convergente com a via existente e traçada a partir das informações obtidas no Itinerário de Antonino e evidências materiais (entidades) conservadas.

A segunda análise de cálculo de caminho ótimo foi seguindo os pontos referentes as capita viarum, ou seja, as capitais conventuais: Bracara Augusta, Lucus Augusti e Asturica Augusta. Dessa forma, ao forçar a passagem por esses pontos (nós) referentes as capita viarum, observa-se que o resultado do traçado do caminho ótimo é muito mais divergente com a via existente e traçada a partir das informações obtidas no Itinerário de Antonino e evidências materiais.

A seguir, com o objetivo de propiciar inteligibilidade e sentido a essas abordagens experimentais, apresentamos os mapas, por via, com os resultados do cálculo de caminho ótimo. Os mapas seguintes foram convertidos em KMZ para poderem ser visualizados no Google earth pro ${ }^{\circledR}$. Entretanto, os mapas de cada via que foram elaborados a partir da análise do relevo, em MDT, estão anexos no final deste capítulo.

Assim, os mapas seguintes, representados nas Figuras 4.3.f a 4.3.h, ilustram o resultado de cálculo de caminho ótimo as Vias XVII, XVIII e XIX, respectivamente. Os mapas com os resultados de cálculo de caminho ótimo das Vias XVII, XVIII e XIX elaborados com base no Modelo Digital do Terreno, gerado à partir do SRTM, estão no Anexo 2.

As legendas desses mapas correspondem à seguinte análise:

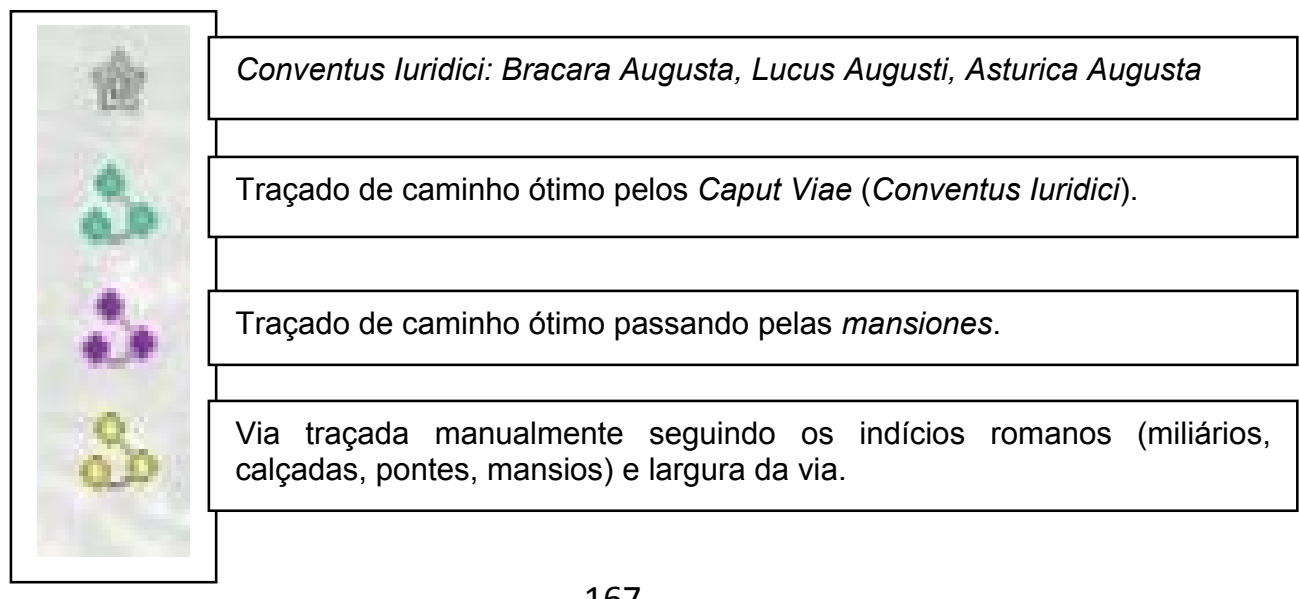




\section{3.f Via XVII - Traçado comparativo}

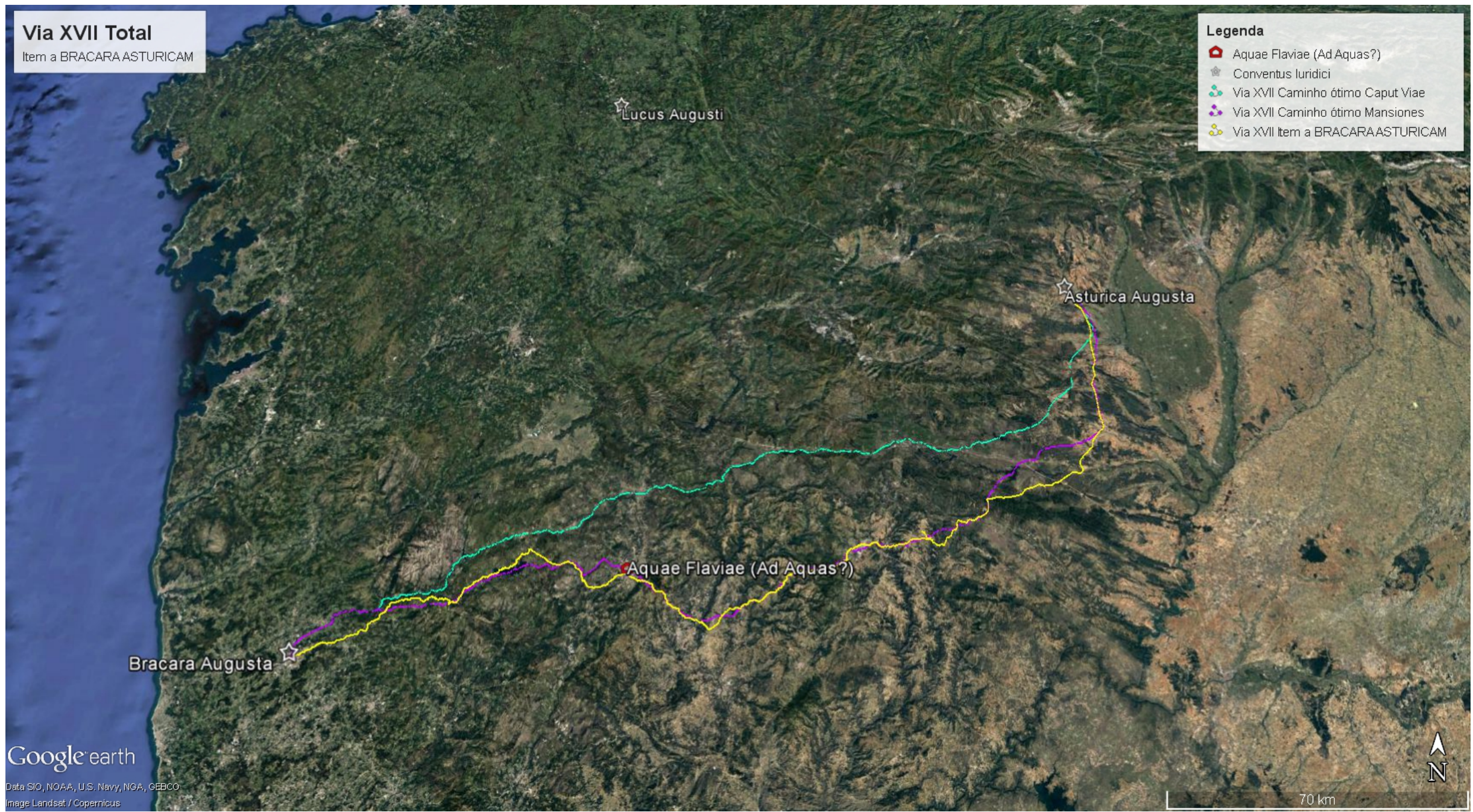




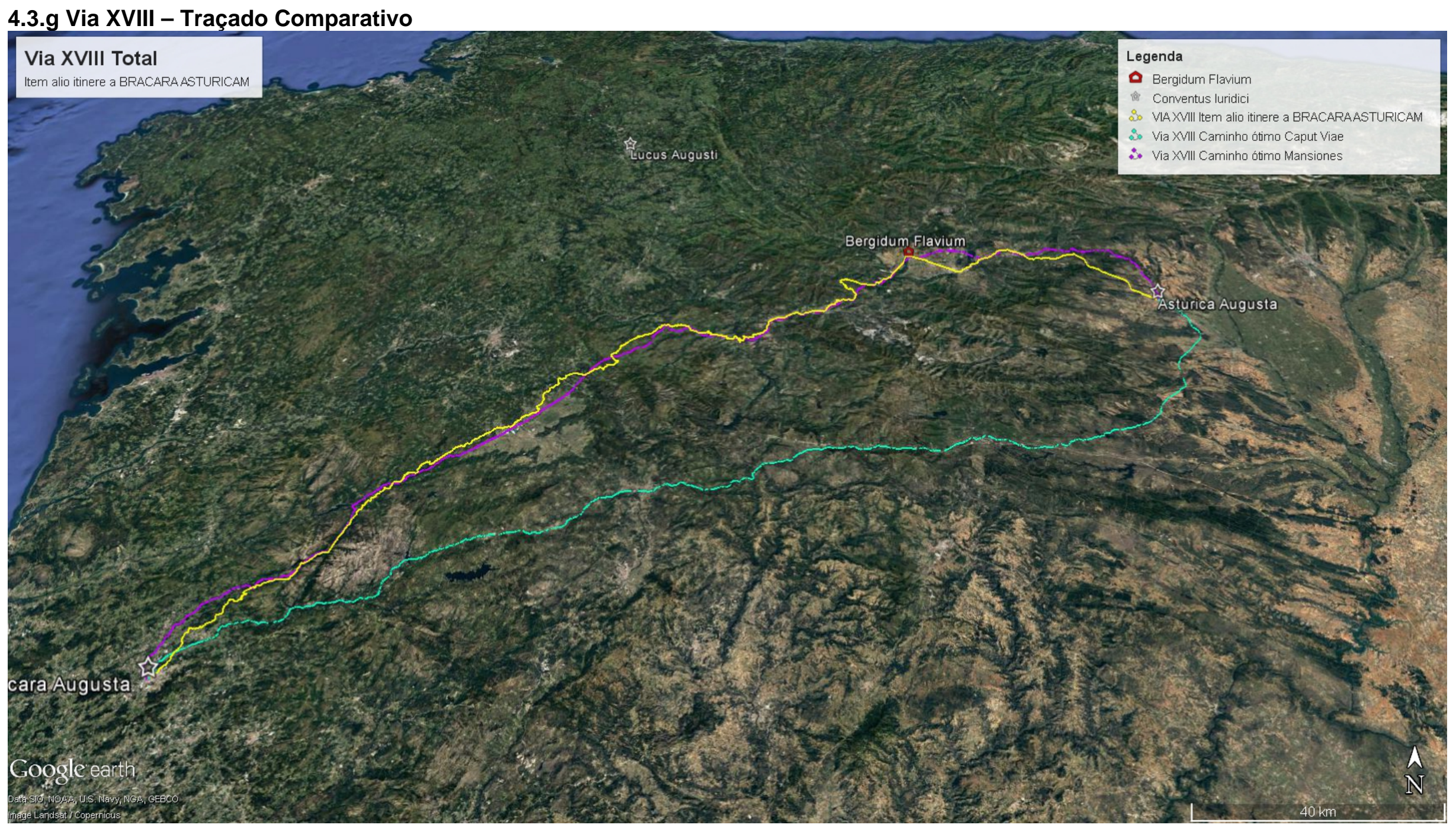




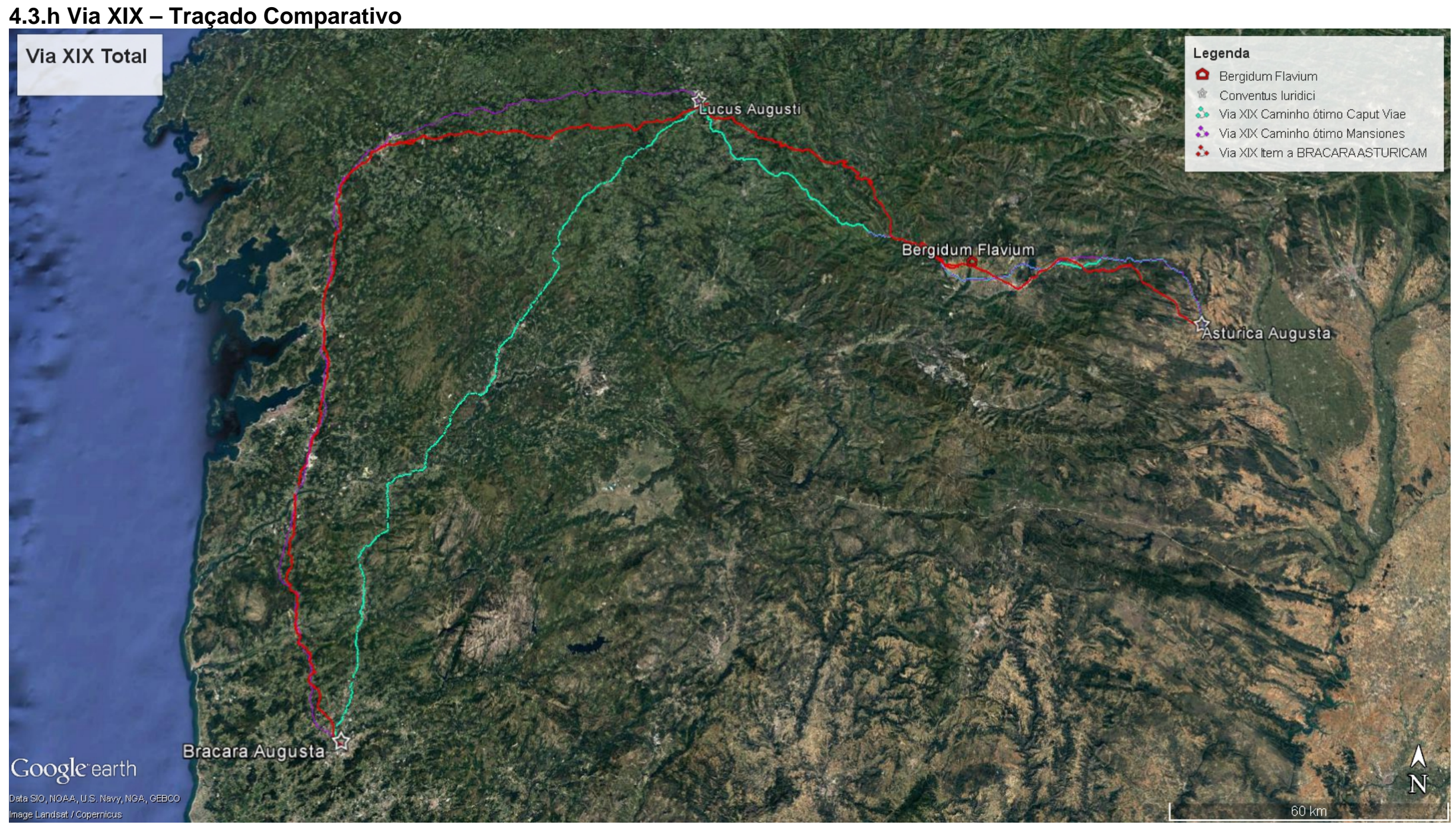




\section{CONSIDERAÇÕES FINAIS}

Em termos metodológicos, a primeira observação relaciona-se com as possibilidades analíticas das tecnologias geoespaciais. As capacidades de modelização, abstração e alteração dos dados de partida são o principal trunfo que essas ferramentas fornecem, além do seu potencial já conhecido para análise de grandes conjuntos de informações.

A próxima observação relaciona-se com a representatividade dos resultados. $O$ que as tecnologias geoespaciais proporcionam, particularmente os SIG, é uma forma de representar a realidade, de modelá-la e adaptá-la ao que devem ser, necessariamente, condições previamente estabelecidas a partir do projeto com as hipóteses que a análise poderá verificar. De toda forma, o significado histórico desses resultados não é evidente por si mesmo, mas pode ser dado a partir de uma leitura que Ihe faça sentido, o que inclui dar inteligibilidade e mentalmente fazer com que os mapas vistos e analisados interajam uns com os outros (RIBEIRO, 1963; LYNCH, 1997).

Em termos interpretativos e de significância histórica, uma das consequências mais relevantes da análise está relacionada com a consideração da mobilidade como fator locacional nas mansiones. A proposta interpretativa é a importância locacional da rede concreta de caminhos que une as diferentes mansios. Portanto, temos que levar em conta a importância dessas localizações das mansios em relação ao itinerário. Assim, via e mansio formam um conjunto estratégico fundamental para a sócioeconomia da época romana. Uma se apoia na outra.

Essa relação divergente entre as mansiones e mobilidade tem correspondência de forma direta com o que podemos caracterizar como modelos locacionais tendentes a conformação de espaços de convergência entre as várias mansiones e/ou assentamentos (Parcero 2000, 2002).

Provavelmente, uma das hipóteses é que o Itinerário de Antonino compilaria os grandes eixos de interesse para a classe dirigente do império, e ignoraria outros itinerários de caráter local ou mesmo provincial. As rotas do Itinerario se assemelhariam com as principais artérias que permitiam a metrópole explorar e exportar para Roma os recursos das províncias, assim como dar suporte a logística necessária para defender as fronteiras de mundo romano.

Portanto, a partir dos estudos realizados em campo, com o levantamento de dados arqueológicos - calçadas, miliários, mânsios etc. -, das fontes históricas disponíveis, especialmente, o Itinerário de Antonino, e da análise utilizando como ferramenta principal o SIG, foram gerados modelos digitais de terreno que demonstraram que a rede viária romana no Noroeste Peninsular não foi implantada com base apenas na lógica de simplesmente unir diretamente as três capitais conventuais fundadas por Augusto (Bracara Augusta, Lucus Augusti e Asturica Augusta). 
Foi possível perceber que os romanos estabeleceram traçados viários baseados na lógica dos "caminhos ótimos de deslocamento" entre os diferentes "nós viários" que precisavam ser comunicados, ou seja, os núcleos estratégicos que acabaram, dessa forma, por se tornar cruzamentos das vias, os pontos nodais para o controle e exploração do território.

Além disso, algumas delas eram vias logísticas para as importantes minas auríferas, localizadas na região de León, Lugo e Orense, caso da Via XVIII. Os imperadores Flávios tiveram diversos motivos para abrir uma nova via em 79 d.C. que ligaria Asturica com a região de El Bierzo, ou seja, para explorar novas áreas auríferas, melhorar a comunicação com as mansiones de Interamnio e Bergidum, localizadas fora do alcance da calçada da conquista, e facilitar a passagem invernal pelos Montes de León.

A partir de Augusto, tendo o exército como agente de integração regional, se produziu uma articulação conjunta do território da Hispânia; com o surgimento do fenômeno urbano; a diversificação e consolidação do povoamento no Noroeste Peninsular; e os fenômenos relacionados com o desenvolvimento da mineiração e as rotas.

O mapa da espacialidade da rede de calçadas romanas no Alto Império nos permite observar a trama viária de umas cidades a outras, tanto de núcleos urbanos quanto de aglomerações secundárias, como os mansios. Isso é indicativo de uma hierarquização padronizada, segundo a qual os núcleos localizados em nós viários foram imprescindíveis para a implementação do projeto de reforma administrativa de caráter totalizador iniciado por Augusto.

A lógica do povoamento romano estava baseada preferentemente em locais de cruzamento de vias terrestres e de rotas fluviais/marítimas, objetivando o controle desses nós viários estratégicos de comunicação. Isso demonstra a capacidade romana de transformar a paisagem, rural e urbana, sendo indicativo de organização, de controle de exploração do território e dos recursos disponíveis.

Finalizamos enfatizando a capacidade dos Sistemas de Informação Geográfica (SIG) para a integração dos conhecimentos geográfico com o arqueológico e histórico. O uso combinado de diversas metodologias produz novas leituras para antigos dados, além de propiciarem o estabelecimento de novas informações anteriormente inacessíveis. Por fim, esses novos dados colocam em debate questões consideradas pré-estabelecidas com relação ao Noroeste Peninsular romano (e também préromano).

O uso dos Sistemas de Informação Geográfica (SIG) para calcular caminhos ótimos permitiu melhorar nossa compreensão qualitativa da articulação da rede viária de uma paisagem em períodos em que normalmente não existe documentação sobre os padrões de mobilidade dessas sociedades pretéritas. Ainda assim, devemos ser sempre críticos com os resultados, principalmente porque os fatores utilizados nesses cálculos, como já observado, vem normalmente a partir de dados atuais e muito gerais, sendo escassas as vezes em que podemos ter a disposição estudos paleoambientais de um território. É, portanto, necessário para acompanhar todo esse 
tipo de cálculos de análise e design crítico e apresentá-los como elementos de orientação da nossa investigação.

O estudo que apresentamos sempre seguiu uma intenção demonstrativa, por isso tem sido direcionado de modo a apresentar uma metodologia de trabalho mais do que resultados conclusivos. Os resultados obtidos só nos permitem conhecer vias hipotéticas de comunicação nas quais o esforço de deslocamento é menor. Entretanto, o resultado nos permite incorporar um novo elemento de avaliação: mostra que os caminhos ótimos apresentados para ligar as capitais conventuais são traçados "naturais", ou seja, espaços pelos quais é natural se locomover; ou forçados, ou seja, espaços através dos quais só podemos esperar para se mover para chegar a locais concretos, caso dos caminhos ótimos relacionados a conexão entre as mansiones.

Dessa forma, para validação, o cálculo de rotas ótimas necessitaria de verificação empírica posterior dos resultados obtidos, assim como uma análise crítica onde se tente avaliar as circunstâncias que levaram à sua formação. 


\section{REFERÊNCIAS BIBLIOGRÁFICAS}

\section{FONTES LITERÁRIAS}

APIANO. Guerras Civiles (Libros I-II): HISTORIA ROMANA, VOL. II. Madrid: Editorial Gredos, 1985.

APIANO. Historia Romana, T.1. Madrid: Editorial Gredos, 1995.

APIANO. Sobre Iberia y Anibal. Madrid: Ed. Alianza, 1993.

AVIENO. Ora marítima. FHA, I, Barcelona, 1955.

CORPUS INSCRIPTIONUM LATINARUM, II (CIL).

DION CASIO. Historia romana. Madrid: Ed. Gredos, 2004.

ESTRABÃO. Geografía de Iberia. Madrid: Ed. Alianza, 2007.

FLORO, Lúcio Aneu. Epítome da história de Tito Lívio. Madrid: Editorial Gredos, 2000.

OROSIO, Paulo. Historias. Obra completa. Madrid: Editorial Gredos, 1982.

PLÍNIO. Naturalis Historia. Madrid: Ed. Cátedra, 2002.

POLIBIO. Historias. Madrid: Akal, 1986.

PTOLOMEU. Claudii Ptolemaei Geographia, v. 1. Paris: Didot, 1883 (K. Müller).

TITO LIVIO. Ab urb condita. Madrid: Editorial Gredos, 1985.

\section{FONTES BIBLIOGRÁFICAS}

ABAD CASAL, L. De Iberia in Hispaniam: La adaptación de las sociedades ibéricas a los modelos romanos. Alicante: Universidad de Alicante, 2003.

ABAD CASAL, L.; ABASCAL, J. Las ciudades y los campos de Alicante en época romana. Alicante: Monográfico de Canelobre, 4, 2003.

ABAD CASAL, L.; BENDALA GALAN, M. Urbanismo y ciudad: de las formaciones ibéricas a la consolidación del modelo romano. Actas del XXIII Congreso Nacional de Arqueologia, (Elche, 1995). Zaragoza, p. 11-20, 1997.

ABASOLO, J. A. El conocimiento de las vías romanas. Un problema arqueológico. Simposio de Tarazona. La Red Viaria en la Hispania Romana, 7-20, 1987.

ACUÑA CASTROVIEJO, F. Actividades do Departamento de Historia 1. Gallaecia, 11, 351-4. Sada: Ediciós do Castro, 1989.

AGUILÓ, M. et al. Guía para la elaboración de estudios del medio físico. Contenido y metodología. Monografias de la Secretaria de Estado para las Políticas del Agua y el Medio Ambiente. Madrid: Secretaría General Técnica del M.O.P.T., 1993. 
ALARCÃO, J. de. O Domínio Romano em Portugal. 4. ed. Mem Martins: Publicações Europa-América, 2002.

ALARCÃO, J. de. As Civitates do Norte de Portugal. Cadernos de Arqueologia, Série II, 12-13, p. 25-30, 1995-96.

ALARCÃO, J. de. A cidade romana em Portugal: a formação de 'lugares centrais' em Portugal, da Idade do Ferro à romanização. In: Cidades e História. Lisboa: Fundação Calouste Gulbenkian, 1992.

ALARCÃO, J. de. Roman Portugal. Vol. I: Introduction. Vol.II: Gazetteer. Warmister: Aris \& Phillips, 1988.

ALBERTOS FIRMAT, M. L. Organizaciones suprafamiliares en la Hispania antigua. Studia Archaeologica, 37, Valladolid, 1975, p. 5-66.

ALFÖLDY, G. História Social de Roma. Lisboa: Presença, 1989.

ALFÖLDY, G. El nuevo edicto de Augusto de El Bierzo en Hispania. In: GRAU, L. HOYAS, J.L. (ed.). El bronce de Bembibre. Un edicto del emperador Augusto. León, 2001, p. 17-28.

ALLEN, K.; GREEN, S.; ZUBROW, E. (Eds.). Interpreting Space: GIS and archaeology. London: Taylor and Francis, 1990.

ALMAGRO, M. Las fuentes antiguas, los restos filológicos y elementos antropológicos sobre la invasión céltica en España. HEMP, I, $2^{\text {a }}$ parte, 1975.

ALMEIDA, C. A. Brochado de. A rede viária do Conventus Bracaraugustanus - via Bracara-Asturicam Quarta, Minia, ${ }^{a}{ }^{\text {série, }} 2$ (3), p. 61-163, 1979.

ALMEIDA, C. A. Ferreira de As vias medievais Entre Douro e Minho, (fotocopiado), Faculdade de Letras do Porto, Porto, 1968.

ALMEIDA, C. A. Ferreira de. Escavações Arqueológicas em Santo Estevão da Facha. Ponte de Lima, 1981.

ALMEIDA, J. P. de. A extinção do arco-íris: ecologia e história. Rio de Janeiro: Centro Edelstein de Pesquisas Sociais, 2008.

ALONSO, V. Primeras etapas en la conquista romana de Gallaecia. MILITARIA. Revista de historia militar, p. 53-66, 1996.

ALONSO-NÚÑES, J. M. Reflexiones sobre el Imperialismo Romano in Hispania. Studia Historica, Historia Antigua, 7. Espanha: Ediciones Universidad de Salamanca, 1989, p. 7-10.

ALONSO TRIGUEROS, J. M. Modelo gráfico para la datación de vías romanas empedradas a partir del estudio de sus estados de frecuentación y del análisis superficial de roderas. Tese (Doutorado). E.T.S.I. Caminos, Canales y Puertos, Universidad Politécnica de Madrid, 2014.

ÁlVAREZ MARTíNEZ, J. M.; BASARRATE, T. Nogales. Calzadas de Lusitania: programación e ideología imperial, Las Comunicaciones en Lusitania Romana. Mérida, p. 255-276, 2003. 
AMOR MEILÁN, M. Historia de la Provincia de Lugo. vol. I: Edad Prehistórica. Lugo: Excma. Diputación Provincial de Lugo, 1918.

ANDRESEN, T. Para a Crítica da Paisagem. Tese (Doutorado). Universidade de Aveiro, Portugal, 1992.

ARAÚJO, A. Teoria e Método em Arqueologia Regional: um estudo de caso no Alto Paranapanema, estado de São Paulo. Tese (Doutorado em Arqueologia). MAE/USP. São Paulo, 2001.

ARCE, J. El 'cursus publicus' en la Hispania Tardorromana. Actas del Simposio sobre la Red Viaria de Hispania Romana. Zaragoza, 1990, p. 35-40.

ARIAS BONET, G. Repertorio de Caminos de la Hispania romana. Madrid, 1987.

ARIAS BONET, G. Los orígenes de Madrid a la luz de la interpretación gramatical del itinerario de Antonino. In: Camineria hispánica: Actas del I Congreso de Caminería Hispánica, Vol. 1, 1993 (Caminería física), p. 69-78.

ARIAS BONET, G. Significado de los casos gramaticales en los itinerarios romanos. In: $3^{\circ}$ Congresso de Arqueología Peninsular. UTAD, Vila Real, Portugal, setembro de 1999, Vol. 6, 2000 (Arqueología da antiguidade na Península Ibérica), p. 267-280.

ARIAS BONET, G. Mansionibus supra scriptis, II: El Itinerario de Antonino, las mansiones y la teoría de los empalmes. El Nuevo Miliario: boletín sobre vías romanas, historia de los caminos y otros temas de geografía histórica, $\mathrm{N}^{\circ}$. 6, 2008, p.78-83

ARIAS VILAS, F. A Romanización de Galicia. Vigo: Promocións Culturais Galegas, 1992.

ARIAS VILAS, F. Tres nuevas piezas de la colección A. Gil Varela en el museo provincial. BCM Lugo, 9, 1976, p. 250-253.

ARIAS VILAS, F.; LE ROUX, P.; TRANOY, A. Inscriptions romaines de la província de Lugo. Paris: Centre Pierre Paris, 1979 (Publicações do Centre Pierre Paris, 3).

ARIÑO GIL, E.; GURT I ESPARRAGUERA, J. M. \& PALET MARTÍNEZ, J. M. EI Pasado Presente. Arqueología de los paisajes em la Hispania Romana. Ediciones Universidad de Salamanca; Publicaciones i Edicions de la Universitat de Barcelona, 2004.

ASHMORE, W. Social Archaeologies of Landscape. In: MESKELL, L.; PREUCEL, R. W. (Ed.). A Companion to Social Archaeology. Oxford: Blackwell, 2004.

ASHMORE, W.; KNAPP, A. B. (Eds). Archaeologies of Landscape: Contemporary Perspectives. New Jersey: Blackwell Publishing, 1999.

AUDI, R. (Ed.). The Cambridge Dictionary of Philosophy. 2. ed. Cambridge: Cambridge University Press, 1999.

AYÁN VILA, X. M. Arquitectura doméstica y construcción del espacio social en la Edad del Hierro del NW. In: BLANCO, A. et al. Bronce Final y Edad del Hierro en la Península Ibérica. Salamanca: Ediciones Universidad, p. 34-54, 2005. 
AYÁN VILA, X. M. Casa, Familia y Comunidad en la Edad del Hierro del NW. Tese. Santiago de Compostela: Universidad de Santiago de Compostela, 2012.

AYÁN VILA, X. M. Os Castros de Neixón, II: de espazo natural a paisaxe cultural. Serie Keltia, 40, Noia: Toxosoutos, 2008.

BALIL, A. De nuevo sobre la Galicia y sus relaciones maritimas durante la época imperial romana. In: III Congresso Nacional de Arqueologia (Porto, 1973). Porto, p. 211-221, 1974.

BALIL, A. Galicia y el comercio atlántico en época romana. In: II Congresso Nacional de Arqueologia (Coimbra, 1970), vol. II. Coimbra, p. 341-346, 1971.

BALIL, A. Nueva Historia de España en sus textos: Prehistoria y Edad Antigua. Santiago de Composterla: Ed. Pico Sacro, 1976.

BANCALARI MOLINA, A. Orbe Romano e Imperio Global. La Romanización desde Augusto a Caracalla. Santiago: Editorial Universitaria, 2007.

BARCELÓ, J. A. Arqueología y Estadística I: Introducción al estudio de la variabilidad de las evidencias arqueológicas. Bellaterra: Servei de Publicacions de la UAB, 2007.

BARCELÓ, J. A. Arqueología, Lógica y Estadística. Bellaterra: Servei de Publicacions de la UAB, 1991.

BARCELÓ, J. A. Computational Intelligence in Archaeology. Hershey, New York: The IGI Group, 2009.

BARCELÓ, J. A. Una interpretación socioeconómica del Bronce Final en el Sudoeste de la Península Ibérica. Trabajos de prehistoria, 49, 1992, p. 259-276.

BARROS SILVELO, R. Antigüedades de Galicia. A Coruña: Imprenta de D. Domingo Puga, 1875.

BELTRÁN LLORIS, F. Nos celtis genitos et ex hiberis. Apuntes sobre las identidades colectivas en Celtiberia. In: CRUZ ANDREOTTI, G.; MORA, B. (Coords.). Identidades étnicas, identidades políticas en el mundo prerromano hispano. Málaga, p. 87-145, 2004.

BELLO GARNELO, F. La toponimia de la zona arqueológica de las Médulas (León): la toponimia del espacio geográfico de los Ayuntamientos de Borrenes, Carucedo y El Puente de Domingo Flórez. León: Universidad de León, 2001.

BELLO DIÉGUES, J. Brigantium y su faro: contextos arqueológicos en la ciudad de A Coruña. Brigantium, 20, p. 41-66, 2009.

BENDALA GALAN, M. La etapa final de la cultura ibero-turdetana y el impacto romanizador. In: La baja época de la cultura ibérica. Actas de la mesa redonda celebrada en conmemoración del décimo aniversario de la Asociación Española de Amigos de la Arqueología, Madrid, (marzo 1979). Madrid: Asociación Española de Amigos de la Arqueología, 1981, p. 30-48. 
BENDALA GALAN, M. La cultura en la Hispania romano-republicana. Cuestiones generales. In: Historia General de España y América, 1.2, Madrid, 1987, p. 569-593.

BENDALA GALAN, M. La genesis de la estructura urbana en la España Antigua. CuPAUAM, 16, 1989, p. 127-147.

BENDALA GALAN, M. La Paz Augustea y la Romanización. In: AA.VV, Hispania el legado de Roma. Zaragoza: Ministerio de Educación y Cultura, 1998, p. 127137.

BENDALA GALAN, M. Los estudios ibéricos ante el reto de un nuevo milênio. In: BLÁNQUEZ PÉREZ, J.; RÓLDAN GÓMEZ, L. (Coords). La Cultura Ibérica a través de la fotografía de principios de siglo: El litoral mediterrâneo. Alicante: Caja de Ahorros del Mediterráneo, 2000, p. 289-302.

BERGGREN, J. L.; JONES, A. (Eds.). Ptolemy's Geography: An annotated translation of the theoretical chapters. Princeton: Princeton University Press, 2000.

BERMÚDEZ SÁNCHEZ, J. Rutinas para el cálculo acumulado de visibilidades y rutas óptimas: algunas reflexiones sobre prospección, SIG, gestión y análisis espacial en arqueología. Arqueología Espacial 24-25, Prospección, Teruel, 2004.

BESSE, J.-M. Ver a Terra: Seis Ensaios sobre a Paisagem e a Geografia. São Paulo: Editora Perspectiva, 2011.

BETTENCOURT, Ana M. S. A Pré-História do Minho. Do Neolítico à Idade do Bronze. In: PEREIRA, P. (Coord.). Minho. Traços de Identidade. Braga: Ed. do Conselho Cultural da Universidade do Minho, p. 70-121, 2009.

BETTENCOURT, Ana M. S. O povoado de S. Julião, Vila Verde, Norte de Portugal, nos Finais da Idade do Bronze e na Transição para a Idade do Ferro, Cadernos de Arqueologia, Monografias n. ${ }^{\circ}$ 10, Universidade do Minho, Braga, 2000.

BLANCO-ROTEA, R.; COTA-GARCÍA, J. M.; FONTE, J.; GAGO-MARIÑO, M.; GONÇALVES, J. A. A Modern Age redoubt in a possible Roman camp. The relationship between two defensive models in Campos (Vila Nova de Cerveira, Minho Valley, Portugal). Journal of Archaeological Science: Reports, 10, p. 293-308, 2016.

BLÁZQUEZ, J. M. Economía de los pueblos prerromanos del área no ibérica hasta la época de Augusto. In: TARRADELL, M. (Ed.). Estudios de Economía Antigua de la Península Ibérica. Ponencias presentadas a la $1^{a}$ Reunión de Historia de la economía antigua de la Península Ibérica. Valencia 1968. Barcelona 1968, p. 191-269.

BLÁZQUEZ, J. M. El impacto de la conquista de Hispania en Roma (218-154 a.C.). Estudios Clásicos, 7, 1962, p. 1-29.

BLÁZQUEZ, J. M. La Romanización I. Madrid: Editorial Istmo, 1995. 
BLÁZQUEZ, J. M. Religiones, ritos y creencias funerarias de la Hispania prerromana. Madrid: Biblioteca Nueva, 2001.

BONAMETTI, J. H. A paisagem urbana como produto do poder. urbe. Revista Brasileira de Gestão Urbana, v. 2, n. 2, p. 259-273, jul./dez. 2010.

BOSCH-GIMPERA, P. Etnología de la Península Ibérica. Barcelona, 1932.

BOSWORTH, A. B. Asinius Pollio and Augustus. Historia, 21, 1972, p. 441 - ss.

BOUHIER, A. La Galice. Essai géographique d'analyse et d'interprétation d'un vieux complexe agraire. La Roche-sur-Yon: Imprimerie Yonnaise, 1979.

BROUGHTON, T. R. S. The romanization of Spain. The problem and the evidence. Proceedings of the American Philosophical Society, 103, p. 645-651, 1959.

BRUNET, R. Le Déchiffrement du Monde. Théorie et pratique de la géographie. Paris: Belin, 2001.

BRUNT, P. A. Laus Imperii. In: CHAMPION, C. B. (Ed.). Roman Imperialism: Readings and Sources. Oxford: Blackwell Publishing, p. 163-185, 2004.

BURILLO MOZOTA, F. Origen y desarrollo de la ciudad en la Celtiberia. In: CRUZ, Pedro M. Santuarios, oppida y ciudades: Arquitectura sacra en el origen y desarrollo urbano del Mediterrábeo Occidental, Anejos de AEspA 45, p. 175194. Mérida: Consejo Superior de Investigaciones Cientificas, Instituto de Arqueologia de Mérida, 2009.

BURILLO MOZOTA, F. Oppida y ciudades estado del norte de Hispania con anterioridad al 153 a.C. In: BURILLO MOZOTA, F. (Ed.). Segeda y su contexto histórico: entre Catón y Nobilior (195 al 153 a.C.): homenaje a Antonio Beltrán Martínez. Zaragoza: Centro de Estudios Celtibéricos de Segeda, 2006, p. 35-70.

BURILLO MOZOTA, F. Segeda, Arqueología y Sinecismo. Archivo Español de Arqueología, 76, p. 193-215, 2003.

BURILLO MOZOTA, F. Excavaciones arqueológicas en Segeda I. Área 3. Salduie, 2, Universidad de Zaragoza, p. 415-430, 2001-2002.

BURILLO MOZOTA, F. Los Celtíberos. Etnias y estados. Barcelona: Editorial Crítica, 1998.

BURÓN ALVAREZ, M. El trazado urbano en las proximidades del foro en Asturica Augusta. La casa del pavimento de opus signinum. Arqueología en Castilla y León, 2, Junta de Castilla y León, Astorga: p. 289-312, 1997.

BUTZER, K. Arqueologia: una ecologia del hombre. Barcelona: Bellaterra, 1989.

CAAMAÑO GESTO, J. M. El campamento bajoimperial romano en Hispania: El campamento de la Cohors I Celtiberorum. Ciudad y Torre. Roma y la Ilustración en A Coruña. A Coruña, p. 19-22, 1991.

CAAMAÑO GESTO, J. M. El trazado de la vía XVIII del Itinerario de Antonino en Galicia. Cadernos de Arqueología, Série II, 12-13, 1995-96, p. 45-87. 
CAAMAÑO GESTO, J. M. Estampillas de la Cohors I Celtiberorum hallada en el campamento romano de Cidadela, Sobrado dos Monxes. Gallaecia, 11, 1989.

CAAMAÑO GESTO, J. M.; MEIJIDE CAMESELLE. El miliario de Friol: aportaciones al conocimiento de la vía XIX. BMPL, 8 (1), Lugo: Deputación Provincial, 1997/98.

CAAMAÑO GESTO, J. M.; NAVEIRO LOPEZ, J. Aportaciones al estudio de la red viaria romana de la provincia de A Coruña. Finisterre, homenaje a Alberto Balil. Santiago de Compostela Universidade de Santiago de Compostela, p. 207224, 1991.

CABALLERO ZOREDA, L.; LATORRE GONZÁLEZ-MORO, P. El faro de La Coruña, llamado La Torre de Hércules. In: AA.VV, Hispania el legado de Roma. Zaragoza: Ministerio de Educación y Cultura, 1998, p. 453-457.

CABERO DIEGUES, V. Evolución y estructura urbana de Astorga. León: Institución "Fray Bernardino de Sahagun" C.S.I.C; Departamento de Geografía, Universidad de Salamanca, 1973.

CALO, F.; SIERRA, J. C.: As orixes do castrexo no Bronce Final. In: PEREIRAMENAUT, G. (Ed.). Estudos de cultura castrexa e de historia antiga de Galicia. Santiago de Compostela, 1983.

CAMBI, F.; TERRENATO, N. Introduzione all'archeologia dei paesaggi. Roma: Nuova Italia Scientifica, 1994.

CAMINO MAYOR, J.; PERALTA LABRADOR, E.; TORRES MARTÍNEZ, J. F. (Coords.). Las Guerras Astur-Cántabras. Oviedo: KRK Ediciones, 2015.

CAMPORESI, C.; PALOMBINI, A.; PESCARIN, S. "Revolution OS" in archeologia: esempi di interfacce web per l'archeologia del paesaggio. In: BAGNARA, R.; MACCHI JANICA, G. (Eds.). Open Source, Free Software e Open Format nei processi di ricerca archeologici. Grosseto, 2007, p. 225-236.

CANO PAN, J. Informe Valorativo 2. Excavación arqueológica en área del castro de Cociñadoiro en Punta Langosteira y Propuesta de liberalización del resto de la superficie ocupada por el yacimiento, 2005.

CAPALVO LIESA, A. Celtiberia. Zaragoza: Institución “Fernando El Católico”, 1996.

CAPELA, M. Miliários do Conventus Bracaraugustanus em Portugal. 3. ed. Concello de Lobios: Câmara Municipal de Terras do Bouro, 1995 (1895).

CARBALLO ARCEO, X. Espacio e povoamento castrexo de Galiza. In: ASOCIACIÓN GALEGA DE HISTORIADORES (Ed.). Concepcións espaciais e estratexias territoriais na Historia de Galicia. Santiago: Tórculo Edicións, 1993, p. 55-82.

CARBALLO ARCEO, X.; FÁBREGAS VALCARCE, R. Variacións rexionais nas sociedades pre e proto-históricas galaicas. In: ÁLVAREZ, R.; DUBERT, F; SOUSA, X. (eds): Lingua e Territorio, 67-91. Santiago de Compostela: ILG, CCG, 2006.

CARDOSO, J. A Geografia da Ibéria segundo Estrabão. Braga: Edições APPACDM Distrital de Braga, 1994. 
CARDOZO, M. Citânia de Briteiros e Castro de Sabroso. Notícia descritiva para servir de guia ao visitante. 11 ed. Guimarães: Sociedade Martins Sarmento, 1990 , p. 58-67.

CARVALHO, Helena Paula Abreu de. A construção do Espaço Ibérico em Época Romana. Conceitos, Escalas e Modelos de Desenvolvimento. Revista de História das Ideias, vol. 31, p. 9-25, 2010.

CARVALHO, Helena Paula Abreu de. O povoamento romano na fachada ocidental do Conventus Bracarensis. Tese (Doutorado em Arqueologia). Braga: Universidade do Minho, 2008.

CASTRO, M. Reconstruyendo un paisaje agrario. La campiña de Jaén en los s. I-II. III Jornadas Históricas del Alto Guadalquivir, Quesada, 1993. P. 175-195, 1999.

CERRILLO MARTÍN DE CÁCERES, E. La reorganización del territorio. Los paisajes de la romanización. In: ABAD CASAL, L. (Ed.). De Iberia in Hispaniam. La adaptación de las sociedades ibéricas a los modelos romanos. Actas del Seminario de Arqueología organizado por la Fundación Duques de Soria. Soria. Convento de la Merced, del 23 al 27 de julio de 2001. Madrid-Alicante, 2003.

CERRILLO MARTÍN DE CÁCERES, E.; FERNÁNDEZ CORRALES, J. M. Contribución al estudio del asentamiento romano en Extremadura. Análisis espacial aplicado al S. de Trujillo. 1980, p. 157-177.

CHAPMAN, H. Landscape Archaeology and GIS. Stroud: Tempus, 2006.

CHEVALLIER, R. Les Voies Romaines. Paris, 1972.

CHIC GARCÍA, G. Roma y el mar: del Mediterráneo al Atlántico. In: ALONSO TRONCOSO, Víctor (coord.). Guerra, exploraciones y navegación: del mundo antiguo a la Edad Moderna. A Coruña: Universidade, 1995, p. 55-90.

CHRISTALLER, W. Central places in Southern Germany. Englewood Cliffs: Prentice-Hall, 1966 [1933].

CLARKE D. L. (Org.). Spatial Archaeology. London, 1977.

CLARKE, D. L. Archaeology: The loss of innocence. Antiquity, 47, Issue 185, March 1973, p. 6-18.

CLAVAL, P. A Geografia Cultural. Florianópolis: UFSC, 1999.

COARELLI, F. II Foro Romano. Periodo arcaico. Roma: Quasar Edizione, 1983.

CONOLLY, J.; LAKE, M. Geographical Information Systems in Archaeology. Cambridge: Cambridge University Press, 2006.

CONOLLY, J.; LAKE, M. Sistemas de Información Geográfica aplicados a la Arqueología. Barcelona: Edicions Bellaterra, 2009.

CONTA, G. La cartografía romana. In: SER, Vol. XII, Valparaíso, 2004, p.41-51.

CORREAA, R. L.; ROZENDAHL, Z. Apresentando leituras sobre paisagem, tempo e cultura. In: CORREAA, R. L.; ROZENDAHL, Z. (Orgs.). Paisagem, Tempo e Cultura. Rio de Janeiro: EDUERJ, p. 7-11, 1998. 
COSTA, J. M. Asentamientos militares romanos en el norte peninsular: aportes de la fotografía aérea histórica, la fotografía digital y el LiDAR aéreo. Férvedes, 8: $p$. 25-44, 2015.

COSTA-GARCÍA, J. M. Las campañas augusteas en el Noroeste peninsular: acción militar y propaganda. Revista Arkeogazte, 5: p. 95-111, 2015.

COSTA-GARCÍA, J. M.; BLANCO-ROTEA, R.; GAGO-MARIÑO, M.; FONTE, J. Novedades sobre la presencia del ejército romano en el occidente galaico. In: CAMINO MAYOR, J.; PERALTA LABRADOR, E.; TORRES MARTÍNEZ, J. F. (Eds.). Las Guerras Astur-Cántabras. Gijón: KRK Ediciones: p. 285-289, 2015a.

COSTA-GARCÍA, J. M.; MENÉNDEZ, A., GONZÁLEZ, D., GAGO-MARIÑO, M., FONTE, J.; BLANCO-ROTEA, R. The presence of the Roman army in NorthWestern Hispania. New archeological data from the ancient Asturian and Galician territories. Comunicação apresentada no 23 Limes Congress 2015 (Ingolstadt, Germany, September 12th-23th), 2015b. Disponível em: http://romanarmy.eu/pt/category/historias/sitios/. Acessado em: 25 set. 2016.

CRESPO MAS, T. Evolución y fundamentos historiográficos del concepto de romanización. Tese (Doutorado). Universidad de Alicante, 2008.

CRIADO-BOADO, F. C. Anteproyecto para el Control del Impacto Arqueológico en Obras Públicas (Oleoducto y Gasificación de Galicia). Grupo de Investigación en Arqueoloxía da Paisaxe. Departamento de Historia I. USC, 1992.

CRIADO-BOADO, F. C. Asentamiento megalítico y asentamiento castreño. Una propuesta de síntesis. Gallaecia, 11: p. 109-37. Sada: Ediciós do Castro, 1989.

CRIADO-BOADO, F. C. Del terreno al espacio: Planteamentos y perspectivas para la Arqueologia del Paisaje. CAPA, 6, GTArPa, USC, 1999.

CRIADO-BOADO, F. C. Límites y posibilidades de la Arqueología del Paisaje. Spal, 2: p. 9-56, 1993.

CRIADO-BOADO, F.; BARREIRO, D. Preâmbulo. In: CRIADO-BOADO, F.; PARCERO OUBIÑA, C.; OTERO VILARIÑO, C.; CABREJAS, E. (Eds.). Atlas Arqueolóxico da Paisaxe Galega. Edicións Xerais de Galicia, 2016, p. 09-18.

CRIADO-BOADO, F.; MAÑANA-BORRAZÁS, P.; GIANOTTI, C. A paisaxe monumental (4500-2500 a. C.). In: CRIADO-BOADO, F.; PARCERO OUBIÑA, C.; OTERO VILARIÑO, C.; CABREJAS, E. (Eds.). Atlas Arqueolóxico da Paisaxe Galega. Edicións Xerais de Galicia, 2016, p. 99-144.

CRIADO-BOADO, F.; PARCERO OUBIÑA, C.; OTERO VILARIÑO, C.; CABREJAS, E. (Eds.). Atlas Arqueolóxico da Paisaxe Galega. Edicións Xerais de Galicia, 2016.

CRUZ, Gonçalo P. C. da. O surgimento do espaço urbano no Noroeste da Ibéria. Uma reflexão sobre os oppida pré-romanos Atas das I Jornadas Internacionais Evolución de los espacios urbanos y sus territórios en el Noroeste de la Península Ibérica. Braga: Universidad de León, Universidade do Minho, 2014. 
CRUZ ANDREOTTI, G. Acerca de Estrabón y la Turdetania-Bética. In: CRUZ ANDREOTTI, G, LE ROUX, P.; MORET P. (Eds.). La invención de una geografía de la Península Ibérica. Vol. 2: La época imperial. Málaga-Madri: CEDMA, 2007, p. 251-270.

CRUZ ANDREOTTI. G. (Coord.). Estrabón e Iberia: Nuevas Perspectivas de Estudio. Málaga: Servicio de Publicaciones de la Universidad de Málaga, 1999.

CULHAM-ERTMAN, P. Curatores Viarum: A Study of the Superintendents of Highways in Ancient Rome. New York: University Microfilms, 1982.

CULLEN, B.; KVAMME, K.; JOHNSON, I; PETRIE, L. (Eds.). GIS in Archaeology. An annotated bibliography. Sydney: 1995 (University Archaeological Methods Series; 1 ).

CUNLIFFE, B. Facing the Ocean. The Atlantic and its Peoples 8000 BC-AD 1500. Oxford: Oxford University Press, 2001.

CUNTZ, O. Itineraria romana. Volumen prius. Itineraria antonini augusti et burdigalense.Studgard: B.G. Teubner, 1929.

CURRÁS-REFOJOS, B.; SASTRE PRATS, I.; OREJAS SACO DEL VALLE, A. Del Castro a la Civitas: Dominación y resistencia en el Noroeste Hispano. In: MORAIS, R.; BANDEIRA, M.; SOUSA, M. J. (Eds.). Celebração do Bimilenário de Augusto: Ad Nationes. Ethnous Kallaikon. Braga: Câmara Municipal de Braga, p. 124-135, 2016.

CURRÁS-REFOJOS, B.; LÓPEZ-GONZÁLEZ, L. Minería romana y poblamiento en la cuenca del Baixo Miño. In: MARTINS, C.; A. BETTENCOURT, A.; MARTINS, J.; CARVALHO, J. (Eds.). Povoamento e Exploração dos Recursos Mineiros na Europa Atlântica Ocidental. Braga: CITCEM/APEQ, p. 179-201, 2011.

DARDEL, E. O Homem e a Terra: Natureza da Realidade Geográfica. São Paulo: Editora Perspectiva, 2011 (1952).

DAVEAU, S. "Comentários e Actualização" (Capítulo "Os recursos do Mar"). In: RIBEIRO, O.; LAUTENSACH, H.; DAVEAU, S. Geografia de Portugal. IV. A vida económica e social. Lisboa: Edições João Sá da Costa, 1991, p. 1133-1154.

DÍAZ SANTANA, B. Los celtas en Galicia. Arqueología y política en la creación de la identidad gallega. Noia: Toxosoutos, 2002.

DOMÍNGUEZ BERENJENO, E. L. Arqueología y Territorio: de la 'interpretación arqueológica' al 'dato histórico'. SPAL, 10, 2001, p. 109-122.

DOPICO CAÍNZOS, D. El proceso de urbanización del Noroeste dentro de la política augústea. In: MORAIS, R.; BANDEIRA, M.; SOUSA, M. J. (Eds.). Celebração do Bimilenário de Augusto: Ad Nationes. Ethnous Kallaikon. Braga: Câmara Municipal de Braga, p. 84-95, 2016.

DOPICO CAÍNZOS, D. As transformacións dos pobos do noroeste hispánico en época de Augusto: a evidência epigráfica. In: DOPICO CAÍNZOS, D.; VILLANUEVA ACUÑA, M.; RODRígueZ ALVAREZ, P. (Eds.). Do Castro á Cidade. A romanización na Gallaecia e na Hispania indoeuropea. Actas do Curso de 
actualización sobre la romanizaciín de Galiza (2008). Lugo: Servizo de Publicacións da Deputación de Lugo, 2009, p. 31-53.

DOPICO CAÍNZOS, D. Política Imperial y Romanización: El papel del emperador Augusto en la Transformación de los pueblos indígenas del Noroeste Hispano. Gallaecia, 25, p. 427-443, 2006.

DOPICO CAÍNZOS, D.; RODRÍGUEZ ALVAREZ, P. Paleoetnografía de Gallaecia. In: ALMAGRO-GORBEA, M.; RUIZ ZAPATERO, G. (Eds.). Complutum, 2-3: Paleoetnología de la Península Ibérica. Madri: Editorial Complutense, 1992. p. 395-398.

DOPICO CAÍNZOS, D.; VILLANUEVA ACUÑA, M.; RODRÍGUEZ ALVAREZ, P. (Eds.). Do Castro á Cidade. A romanización na Gallaecia e na Hispania indoeuropea. Actas do Curso de actualización sobre la romanización de Galiza (2008). Lugo: Servizo de Publicacións da Deputación de Lugo, 2009.

EIROA, J. J. Sobre la Edad del Bronce en el Noroeste de la península hispánica. Caesaraugusta, 37-38, 1973-1974, p. 25-123.

EIROA, J. J. Una fecha radiocarbónica por el noroeste peninsular. Saragoza, 1973.

ELENA, Ana Garrido; MAR, Ricardo; MARTINS, Manuela. A Fonte do Ídolo. Análise, interpretação e reconstituição do santuário. Braga: UAUM - Unidade de Arqueologia da Universidade do Minho, 2008.

ESTEFANÍA ÁLVAREZ, M. Vías romanas de Galicia. Zephyrus, 9, 1960.

FABIÃO, C. et al. Portugal no tempo dos Romanos. Visão Histórica, 17, setembro de 2012.

FABIÃO, C. A dimensão atlântica da Lusitânia: Periferia ou charneira no Império Romano? In: GORGES, J.-G.; ENCARNAÇÃO, J. d'; NOVALES BASARRATE, T.; CARVALHO, A. (Coords.). Lusitânia Romana - Entre o Mito e a Realidade. Cascais: Câmara Municipal de Cascais, 2009, p. 53-74.

FABIÃO, C. A Herança Romana em Portugal. Lisboa: CTT Correios de Portugal, 2006.

FABIÃO, C. Mundo indígena, romanos e sociedade provincial romana: sobre a percepção arqueológica da mudança. (ERA)arqueologia, 3, 2001, p. 108-131.

FÁBREGA-ÁLVAREZ, P. Moving without destination. A theoretical GIS-based determination of movement from a giving origin. Archaeological Computing Newsletter, 64, 2006b, p. 7-11.

FÁBREGA-ÁLVAREZ, P. et al. Los Caminos como Productos Históricos: Análisis de la Movilidad a través de SIG. Lab. De Arqueoloxia da Paisaxe, Instituto Padre Sarmiento. CSIC-Xunta de Galicia, 2006a.

FÁBREGA-ÁlVAREZ, P.; FONTE, J.; GONZÁLEZ GARCÍA, F. J. Mobilidade e materialidade: uma aproximação à análise da localização das estátuas-menir transfronteiriças (Norte de Portugal e Sul da Galiza). Estelas e estátuas-menires 
da Pré à Proto-história. Actas das IV Jornadas Raianas. Sabugal: Câmara Municipal, 2011, p. 245-270.

FÁBREGA-ÁlVAREZ, P.; PARCERO-OUBIÑA, C. Proposals for an archaeological analysis of pathways and movement. Archaeologia e Calcolatori, 18, 2007, p. $121-41$.

FAIRÉN JIMÉNEZ, S. ¿Se hace camino al andar? Influencia de las variables medioambientales y culturales en el cálculo de caminos óptimos mediante SIG, Trabajos de Prehistoria 61, nº 2, p. 25-40, 2004.

FAURE, P.; Ramin, J. Le problème des Cassitérides et les sources de l'étain occidental depuis les temps protohistoriques jusqu'au début de notre ère. Bulletin de l'Association Guillaume Budé, 1, mars 1968. p. 148-149.

FERNÁNDEZ IBÁÑEZ, C. Post vestigium exercitus. Militaria romana en la región septentrional de la Península Ibérica durante la época altoimperial. In: MORILLO CERDÁN, A. (ed.). Arqueología militar romana en Hispania. Producción y abastecimiento en el ámbito militar. León: Universidad de León, 257-308, 2006.

FERNÁNDEZ OCHOA, C. Astures y Roma: la configuración del territorio. In: Astures. Pueblos y culturas en la frontera del Imperio Romano, Gijón, p. 99-111, 1995.

FERNÁNDEZ OCHOA, C. (Ed). Los Finisterres Atlánticos en la Antigüedad. Época Prerromana y Romana (Coloquio Internacional). Madrid: Electa, 1996.

FERNÁNDEZ OCHOA, C.; MORILLO CERDÁN, A. La tierra de los astures. Nuevas perspectivas sobre la implantación romana en la antigua Asturia. Gijón (Asturias): Ediciones TREA, S.L., 1999.

FERNÁNDEZ OCHOA, C.; MORILLO CERDÁN, A.; GIL SENDINO, F. El Itinerario de Barro. Cuestiones de autenticidad y lectura. Zephyrus, 70, p. 151-179, 2012.

FERNÁNDEZ-POSSE, M. D. La investigación protohistórica en la Meseta y Galicia. Madrid: Síntesis, 1998.

FERNÁNDEZ-POSSE, M. D.; SÁNCHEZ-PALENCIA, F. J. La Corona y el Castro de Corporales II. Campaña de 1983 y prospecciones en la Valderia y La Cabrera (León). Excavaciones Arqueológicas en España, 153. Madrid: Ministerio de Cultura, Junta de Castilla y León, 1988.

FERNÁNDEZ-POSSE, M. D.; SÁNCHEZ-PALENCIA, F. J., FERNÁNDEZ MANZANO, J.; OREJAS, A. Estructura social y territorio en la cultura castreña prerromana. Trabalhos de Antropologia e Etnologia, 34 (3-4), Actas del I Congresso de Arqueologia Peninsular, IV. Porto, 1994, p. 191-212.

FERNÁNDEZ-POSSE, M. D.; SÁNCHEZ-PALENCIA, F. J. Ocupación del territorio y estructura social en las poblaciones castreñas astures. In: REDENTOR, A. (Ed.). O $1^{\circ}$ milénio a.C. no noroeste peninsular. A Fachada atlântica e o interior. Actas do Colóquio realizado em Bragança nos dias 24 e 5 de novembro de 1995. Bragança: Parque Natural de Montesinho, 1997, p. 87-106. 
FERNÁNDEZ-POSSE, M. D.; SÁNCHEZ-PALENCIA, F. J. Las comunidades campesinas en la cultura castreña. Trabajos de Prehistoria, 55 (2), Madrid, p. 127-50, 1998.

FERNÁNDEZ-POSSE, M. D.; MENÉNDEZ, E.; SÁNCHEZ-PALENCIA, F. J. El paisaje cultural de Las Médulas. IV Seminari Arqueologia i Ensenyament, Barcelona, 1416 de novembre, 2002; Treballs d'Arqueologia 8, 2002, p. 37-61.

FERNÁNDEZ URIEL, P. Fases de la conquista romana e inícios del asentamiento. In: AA.VV, Hispania el legado de Roma. Zaragoza: Ministerio de Educación y Cultura, 1998, p. 51-64.

FERREIRA DE ALMEIDA, C. A. Influências meridionais na cultura castreja. Revista da Faculdade de Letras, Porto, 4, 1973, p. 199.

FERREIRA DE ALMEIDA, C. A. Minas de Ouro na Gallaecia Portuguesa, Legio VII, Gem. León, 1970.

FERREIRA PRIEGUE, E. Los caminos medievales de Galicia. Ourense: Museo Arqueolóxico Provincial, 1988.

FERRER SIERRA, S. Senalización romana de las vias en el Noroeste de Hispania. In: GALLO, I. M. (Coord.). Nuevos Elementos de ingeniería romana. III Congreso de las obras públicas romanas. Astorga: Junta de Castilla y León - Colegio de Ingenieros, p. 67-81, 2006.

FIGUEIREDO, C. Domus de Santiago. Uma visão do peristilo na sua forma original. Braga: Museu Pio XII, Empresa do Diário do Minho, Lda, 2014.

FLEMING, A. Tombs for the Living. Man New Series, 8 (2), Royal Anthropological Institute of Great Britain and Ireland, p. 177-193, 1973.

FONTE, João Mário Martins da. O "Padrão dos Povos" de Aquae Flaviae. Al-Madan, adenda electrónica, II Série (14), Dezembro 2006, p. 01-07.

FONTE, João Mário Martins da. Sistemas defensivos Proto-Históricos de Trás-OsMontes Ocidental (Norte de Portugal). Cuadernos de Estudios Gallegos, 55 (121), enero-diciembre 2008, p. 9-29.

FONTE, João Mário Martins da. Lesenho e Aquae Flaviae: Dois modelos de assentamento central e duas lógicas locacionais de época pré-romana e romana. Trabalho de Investigação Tutelado para a obtenção do Diploma de Estudos Avançados, Programa de doutoramento "Arqueoloxía, Historia da Antigüidade e Ciencias e Técnicas Historiográficas". Santiago de Compostela: Universidade de Santiago de Compostela, 2009.

FONTE, João Mário Martins da. Novas metodologias não-invasivas de prospecção arqueológica: o contributo das tecnologias geo-espaciais. Forum, 44-45, 2009/2010: p. 97-112, Universidade do Minho, Braga, Portugal.

FONTE, João Mário Martins da. Paisagens em mudança na transição entre a Idade do Ferro e a Época Romana no Alto Tâmega e Cávado. Tese (Doutorado). Departamento de Historia I, Facultade de Xeografía e Historia. Santiago de Compostela: Universidade de Santiago de Compostela, 2015. 
FORNI, G. Dalle difficoltà di assoggetamento agli effetti della romanità: sinossi asturocaleca. Actas del bimilenario de Lugo. Lugo, 1976, p. 52-56

FORTE, M. I Sistemi Informativi Geografici in Archeologia. Roma: MondoGIS, 2002.

FRANCO MASIDE, R. M. Vías naturais e vías romanas na provincia de A Coruña. Gallaecia 19, 1999.

GAGO-MARIÑO, M., MALDE, A. Un posible recinto campamental romano en $\mathrm{O}$ Cornado (Negreira). Nailos, 2: p. 229-251, 2015.

GARCÍA MARCOS, V.; VIDAL ENCINAS, J. M. Asturica Augusta: de asentamiento militar a urbs magnifica. In: RODRÍGUEZ COLMENERO, A. (coord). Los orígenes de la ciudad en el Noroeste hispânico, Actas del Congreso Internacional, Lugo 15-18 de Mayo 1996, Lugo, p. 911-944, 1998.

GARCÍA RIAZA, E. Celtíberos y Lusitanos contra Roma: diplomacia y derecho de guerra. Vitoria: Universidad del País Vasco Servicio Editorial, 2002.

GARCÍA RIAZA, E. La expansión romana en Celtiberia. In: BURILLO, F. (Ed.). Segeda y su contexto histórico: Entre Catón y Nobilior (195 al 153 a.C.): homenaje a Antonio Beltrán Martínez. Zaragoza: Centro de Estudios Celtibéricos de Segeda, p. 81-94, 2006.

GARCÍA SANJUÁN, L. Introducción al reconocimiento y análisis arqueológico del territorio. Barcelona: Ariel Prehistoria, 2005.

GARCÍA VUELTA, O. Orfebrería castreña. Madrid: MAN, 2007.

GILLINGS, M.; MATTINGLY, D. J.; VAN DALEN, J. (Eds.). Geographical Information Systems and Landscape Archaeology. Oxford: Oxbow Books, 1999 (The Archaeology of Mediterranean Landscapes; 3).

GILLINGS, M.; WHEATLEY, D. Seeing is not believing: Unresolved issues in archaeological visibility analysis. In: SLAPŠAK, B. (Ed.). On the Good use of Geographical Information Systems in Archaeological Landscape Studies. Proceedings of the COST G2 Working Group 2 round table Luxembourg. Luxembourg: Office for Official Publications of the European Communities, 2001, p. 25-36.

GIRARDI, E. P. Atlas da questão agrária brasileira. Presidente Pudente: Universidade Estadual Paulista (UNESP), 2008.

GIRARDI, E. P. Subsídios do conceito de espaço geográfico em Milton Santos e em Roger Brunet para uma interpretação sobre a indissociabilidade entre espaço geográfico e território. Revista Mato-Grossense de Geografia, Cuiabá, 17 (1), p. 15-32, jan/jun 2014.

GOLDSWORTHY, A. A Queda de Cartago. As Guerras Púnicas. 265-146 a.C. Lisboa: Edições 70, 2009.

GOMES, P. C. da C. A condição urbana: ensaios de geopolítica da cidade. Rio de Janeiro: Bertrand, 2002. 
GOMES, P. C. da C. Geografia e Modernidade. Rio de Janeiro: Bertrand, 1996.

GÓMEZ ORTIZ, A.; MELÓN ARIAS, M. C. El paisaje como tema transversal en el diseño curricular base (D.C.B.) de la educación obligatoria. La montaña como objeto de estudio. Biblio 3W. Revista Bibliográfica de Geografía y Ciencias Sociales, Universidad de Barcelona, 267, 12 de enero de 2001.

GÓMEZ VILA, J. As vías romanas na actual provincia de Lugo. Achegamento á súa problemática. Historia Nova I, p. 15 -29, 1993.

GÓMEZ VILA, J. Vías romanas de la actual provincia de Lugo. Tese (Doutorado). Programa de Doutoramento en Arqueoloxía e Ciencias da Antigüidade, Universidade de Santiago de Compostela, 2005.

GONZÁLEZ ÁlVAREZ, D.; ÁLVAREZ MARTÍNEZ, V.; JIMÉNEZ CHAPARRO, J. I.; MENÉNDEZ BLANCO, A.; COLLOTO MONTERO, J. ¿Un nuevo establecimiento militar romano en la asturia transmontana? El Picu Viyao (Piloña, Asturias). Férvedes, 7, p. 225-234, 2011.

GONZÁleZ ÁlVAREZ, D.; MENÉdeZ BlANCO, A.; ÁlVAREZ MARTíNEZ, V. El campamento de Moyapán (Ayande, Asturias). Férvedes, 5: p. 363-371, 2008.

GONZÁLEZ BALLESTEROS, I. El estereotipo del bárbaro y la imagen de la civilización en el occidente romano en la Geografía de Estrabón. Espacio, tiempo y forma. Serie II, 22: p. 249-260, 2009.

GONZÁLEZ ECHEGARAY, J. Las Guerras Cántabras en las fuentes. In: ALMAGRO GORBEA, M.; BLÁZQUEZ MARTÍNEZ, J. M. et al. Las guerras cântabras. Santander: Fundación Marcelino Botín, 1999, p. 145-1710.

GONZÁLEZ FERNÁNDEZ, E.; CARREÑO GASCÓN, M.C. La capital del extremo noroeste hispánico: Lucus Augusti y su tejido urbano a la luz de las ultimas intervenciones arqueológicas. In: RODRÍGUEZ COLMENERO, A. (coord). Los orígenes de la ciudad en el Noroeste hispânico, Actas del Congreso Internacional, Lugo 15-18 de Mayo 1996, Lugo, p. 1171-1208, 1998:

GONZÁLEZ GARCÍA, F.J. Los Célticos de Gallaecia: apuntes sobre etnicidad y territorialid ad en la Edad del Hierro del Noroeste de la Península Ibérica. Complutum, 22 (1), Madrid: Publicaciones Universidad Complutense de Madrid, 2011, p. 117-132.

GONZALEZ RODRÍGUEZ, M. C.; SANTOS YANGUAS, J. (Eds.). Las estructuras sociales indígenas del Norte de la Península Ibérica. Vitoria-Gasteiz: Instituto de Ciencias de la Antigüedad, Universidad del Pais Vasco, D.L., 1994.

GONZÁLEZ RUIBAL, A. Camino del Tiempo: Orígenes protohistóricos de la vía XIX. Larouco, 3: p. 157-167, 2001.

GONZÁLEZ RUIBAL, A. Facing two seas: Mediterranean and Atlantic contacts in the north-west of Iberia in the first millennium BC. Oxford Journal of Archaeology, 23 (3), Oxford, p. 287-317, 2004a. 
GONZÁLEZ RUIBAL, A. Galaicos. Poder y Comunidad en el Noroeste de la Península Ibérica (1200 a.C.- 50 d.C.). Brigantium, 18-19. A Coruña: Museo Arqueológico e Histórico da Coruña, 2006-2007.

GONZÁLEZ RUIBAL, A. House societies vs. kinship based societies: an archaeological case from Iron Age Europe. In: O'SHEA, J.M. (Ed.). Journal of Anthropological Archaeology, 25. Stanford: Elsevier, 2006. p. 144-173.

GONZÁLEZ RUIBAL, A.; RODRÍGUEZ MARTÍNEZ, A.; ABOAL FERNÁNDEZ, R.; CASTRO HIERRO, V. Comercio mediterráneo en el castro de Montealegre (Pontevedra, Galicia). Siglo II a.C. - inicios del siglo I d.C. Archivo Español de Arqueología, Madrid, 80, p. 43-74, CSIC, 2007.

GONZÁlEZ RUIBAL, A; AYÁN VILA, X.; RODRÍGUEZ MARTÍNEZ, R. La otra Arqueología Comercial del NW: ciclos de intercambio entre el Atlántico y el Mediterráneo en la Protohistoria y en la Antigüedad. Actas del I Simposio Internacional Gentes del Mar. Historia y Arqueología en el litoral del Arco Atlántico, 16-18 de diciembre de 2009, Luanco (Asturias).

GONZÁLEZ VILLAESCUSA, R. ¿Qué arqueología del paisaje? In: PROSPER, E. G. et al. Catastros, hábitats y vía romana. Proyecto INTERREG III B de la Unión Europea: Las Vías Romanas en el Mediterráneo. Valencia: Generalitat Valenciana, 2006, p. 215-246.

GOODCHILD, M. F. Geographic Information Systems and Spatial Analysis in the Social Sciences. In: ALDENDERFER, M.; MASCHNER, H. D. G. (Eds). Anthropology, Space, and Geographic Information Systems. New York: Oxford University Press, p. 241-250, 1996.

GOTTMANN, J. A evolução do conceito de território. Boletim Campineiro de Geografia, 2 (3), 2012. p. 523-545.

GRANDE RODRÍGUEZ, M. Los castros de la Gallaecia interior: arqueología, poblamiento y sociedad. Herakleion, 1: 85-119, 2008.

GRAU, L. HOYAS, J.L. (ed.). El bronce de Bembibre. Un edicto del emperador Augusto. León, 2001.

GRAU MIRA, I. Dinámica social, paisaje y teoría de la práctica. Propuestas sobre la evolución de la sociedad ibérica en el área central del Oriente Peninsular. Trabajos de Prehistoria, 64 (2), p. 119-142, 2007.

GRAU MIRA, I. La romanización. In: Historia de L' Alcoià, El contat y La foia de Castalla, I, Alicante, 1996, p. 145-156.

GRAU MIRA, I. Transformaciones culturales y modelos espaciales. Aproximación SIG a los paisajes de la romanización. In: GRAU MIRA, I. (Ed.). La aplicación de los SIG en la Arqueología del Paisaje. San Vicente Del Raspeig: Universidad de Alicante, 2006, p. 211-226.

GUÉRIN, P. Introducción. In: GARCÍA-PROSPER, E.; GUÉRIN,P.; MADARIA, J. L.; SÁNCHEZ PÉREZ, P. (Eds.). Catastros, Habitats y Via Romana. Valencia: Generalitat Valenciana, 2006, p. 13-15. 
GUTIERREZ SOLER, L. M.; BELLON RUIZ, J. P. Métodos de investigación y técnicas de análisis arqueológico aplicadas al estudio del territorio. Mundo de Antes. Revista del Instituto de Arqueología y Museo de la Universidad Nacional de Tucumán, 2, Agosto 2001, p. 37-58.

HAESBAERT, R. Concepções de território para entender a desterritorialização. In: Território, Territórios. Programa de Pós-Graduação em Geografia da UFF. Niterói: UFF/ AGB, 2002, p. 17-38.

HAESBAERT, R. O mito da desterritorialização: do "fim dos territórios" à multiterritorialidade. Rio de Janeiro: Bertrand Brasil, 2004.

HÄGERSTRAND, T. The propagation of innovation waves. In: WAGNER, P. L.; MIKESELL, M. W. (Eds.). Readings in Cultural Geography. Chicago: University of Chicago, 1962, p. 355-368.

HARRIS, W. V. War and Imperialism in Republican Rome: 327-70 B.C. Oxford: Clarendon Press, 1979.

HAVERFIELD, F. The Romanization of Britain. Proceedings of the British Academy. Londres: Oxford, 1905-1906.

HAWKES, C. F. C. Escavações no Castro de Sabroso (Abril de 1958). Revista de Guimarães, 68 (3-4), 1958, p. 446-453.

HERNÁNDEZ GUERRA, L.; SAGREDO SAN EUSTAQUIO, L. (Eds.). El processo de municipalización en la Hispania romana. Valladolid: Servicio de Apoyo a la Enseñanza, Universidad de Valladolid, 1998.

HIGGS, E.S. Palaeoeconomy. London: Cambridge University Press, 1975.

HINGLEY, R. Globalizing Roman Culture: Unity, diversity and Empire. London and New York: Routledge, 2005.

HODDER, I. Interpretación en Arqueología. 2 ed. Barcelona: Crítica, 1994.

HODDER, I.; ORTON, C. Spatial Analysis in Archaeology. New York/Cambridge: Cambridge University Press, 1976.

JARMAN, M. R.; VITA FINZI, C.; HIGGS, E. S. Site Catchment Analysis in Archaeology. In: UCKO, P.; TRINGHAM, R.; DIMBLEDY, C. (Eds.). Man, Settlement and Urbanism. Londres: Duckworth, 1972, p. 61-66.

JELLICOE, G.; JELLICOE, S. El paisage del hombre: la conformacion del entorno desde la prehistoria hasta nuestros días. Barcelona: Gustavo Gilli, 1995.

JÍMÉNEZ DÍEZ, A. Imagines Hibridae. Una aproximación postcolonialista al estudio de las necrópolis de la Bética. Anejos del Archivo Español de Arqueología, 43, CSIC, Madrid, 2008.

JIMENO, A. et al. Numancia. Guía del yacimiento. Soria: Asociación de Amigos del Museo Numantino, 1990.

JOHNSON, A. Aspects of regional analysis in archaeology. Annual Review of Anthropology, 6, p. 479-508, 1977. 
KEAY, S. J. La romanización en el Levanter y el sur de España hasta la época de Augusto. In: BLAZQUEZ, J.; ALVAR, J. (Eds.). La romanización en Ocidente. Madrid, 1996, p. 147-177.

KEAY, S. J. Processes in the development of the coastal communities of Hispania Citerior in the Republican Period. In: BLAGG, T.; MILLET, M. (Eds.). The early Roman Empire in the West. Oxford, 1990, p. 120-150.

KEAY, S. J. The Romanization of Hispanies. In: KEAY, S.; TERRENATO, N. Italy and the West. Comparative Issues in Romanization. Oxford, 2001.

KEAY, S. J. Urban Transformation and Cultural Change. In: DIAZ-ANDREU, M.; KEAY, S. J. (Eds). The Archaeology of Iberia: the Dynamics of Change. London, New York: Routledge, 1997, p. 192-209 (Theoretical Archaeology Group-TAG).

KENT, S. Understanding the use of space: an ethnoarchaeological approach. In: Method and theory for activity area research: an ethnoarchaeological approach. New York: Columbia University Press, p.1-60, 1987.

KLEINER, F. S. The trophy on the bridge and the Roman triumph over nature, L'Antiquité Classique, 60: 182-192, 1991.

KOLB, A. Communications and Mobility in the Roman Empire. In: BRUUN, C.; EDMONDSON, J. (Eds.). The Oxford Handbook of Roman Epigraphy. Oxford: Oxford University Press, 2014.

KORZYBSKI, A. Science and Sanity. New York: Science Pess, 1941.

KVAMME, K. L. Geographic Information Systems and Archaeology. In: LOCK, G.; MOFFETT, J. (Eds.). Computer Applications and Quantitative Methods in Archaeology. Oxford: Tempus Reparatum, 1991, p. 77-89 (BAR International Series; 577).

KVAMME, K. L. Recent directions and developments in Geographical Information Systems. Journal of Archaeological Research, 7 (2), 1999, p. 153-201.

LAMAS, José Manuel Ressano Garcia. Morfologia urbana e desenho da cidade. Lisboa: Fundação Calouste Gulbenkian, 1993.

LE ROUX, P. Os Territórios romanos de Portugal no Alto Império. Revista do Museu de Arqueologia, Suplemento, $\mathrm{n}^{\circ}$ 19. São Paulo: Museu de Arqueologia e Etnologia, Universidade de São Paulo, 2014.

LE ROUX, P. Romanos en España. Ciudades y política en las provincias (siglo II a. C.-siglo III d. C.). Barcelona: Edicions Bellaterra, 2006.

LE ROUX, P. Vicus et Castellum en Lusitanie sous l'Empire. In: GORGES, J.-G.; SALINAS DE FRÍAS, M. (Eds.). Les campagnes de Lusitanie romaine. MadridSalamanca, 1994, p. 151-160.

LEFEBVRE. H. A Reprodução das Relações de Produção. Tradução: Antonio Ribeiro e M. do Amaral. Porto: Publicações Escorpião, 1973 (Cadernos O Homem e a Sociedade).

LEFEBVRE. H. The Production of Space. Blackwell Publishing, 2001. 
LEMOS, F. S. A Cultura Castreja no Minho. Espaço Nuclear dos grandes povoados do Noroeste peninsular. In: PEREIRA, P. (Coord.). Minho. Traços de Identidade. Braga: Ed. do Conselho Cultural da Universidade do Minho, p. 122-213, 2009a.

LEMOS, F. S. A transformação do habitat e da paisagem castreja no contexto da romanização: o exemplo dos grandes castros. In: DOPICO CAÍNZOS, D.; VILLANUEVA ACUÑA, M.; RODRÍGUEZ ALVAREZ, P. (Eds.). Do Castro á Cidade. A romanización na Gallaecia e na Hispania indoeuropea. Actas do Curso de actualización sobre la romanizaciín de Galiza (2008). Lugo: Servizo de Publicacións da Deputación de Lugo, p. 143-177, 2009b.

LEMOS, F. Fonte do Ídolo: História e contexto arqueológico do monumento, Mínia, $2^{\mathrm{a}}$ Série, 10, Braga, p. 5 - 23, 2002.

LEMOS, F. S. A via romana entre Bracara Augusta e Asturica Augusta, por Aquae Flaviae (Contributo para o seu estudo), Revista de Guimarães, 110, p. 15-52, 2000.

LEMOS, F. S. Caminhos e Muralhas de Braga, Forum, 18, p. 49-62, 1995.

LEMOS, F. S. Povoamento Romano de Trás-os-Montes Oriental. Tese (Doutorado em Arqueologia). Braga: Universidade do Minho, 1993.

LEMOS, F. S. et al. A Via Nova (Geira) na Serra do Gerês. Trajecto entre as milhas XII e XXXVIII (Bracara Augusta - Aquis Originis). Concello de Lobios: Câmara Municipal de Terras de Bouro, 2008.

LEMOS, F. S.; MEIRELES, C. A. P. Mineração aurífera no conventus de Bracara Augusta. In: $3^{\circ}$ Simpósio sobre mineração e metalurgia históricas no Sudoeste europeu. Porto: SEDPGYM e IPPAR, p.169-183, 2006.

LEMOS, F. S.; MORAIS, P. Vias Augustas e Mineração Aurífera, Forum, 36, p. 15-56, 2004.

LEVEAU, P. L'Archeologie du Paysage et l'Antiquité Classique. Agri Centuriati, 2, Pisa-Roma: Istituti Editoriale e Poligrafici Internazionali, 2006.

LLOBERA, M. Landscapes of experiences in stone: notes on a humanistic use of a Geographic Information System (GIS) to study ancient landscapes. University of Oxford, 1999.

LLOBERA, M. Building past landscape perception with GIS: Understanding topographic prominence. Journal of Archaeological Science, 28, 2001, p. 1005-1014.

LLOBERA, M. Extending GIS-based visual analysis: The concept of visualscapes. International Journal of Geographical Information Science, 17(1), 2003, p. 25-48.

LLOBERA, M. Understanding Movement: a pilot model towards the sociology of movement. In: LOCK, G. R. (Ed.). Beyond the Map: Archaeology and Spatial Technologies. Amsterdam: IOS Press, 2000, p. 65-84 (NATO Science Series A: Life Sciences; 321 ). 
LLOBERA, M., FÁBREGA-ÁLVAREZ, P.; PARCERO-OUBIÑA, C. Order in Movement: A GIS approach to accessibility. Journal of Archaeological Science, 38, 2011, p. 843-51.

LLOBERA, M., WHEATLEY, D., STEELE, J., COX, S.; PARCHMENT, O. Calculating the inherent visual structure of a landscape (inherent viewshed) using highthroughput computing. In: NICCOLUCCI, F.; HERMON, S. Beyond the Artefact: Digital Interpretation of the Past. Proceedings of CAA2004, Prato, 13-17 April 2004. Budapest: Archaeolingua, 2010, p. 146-51.

LOCK, G. R.; STANČIČ, Z. Archaeology and Geographic Information Systems: A European Perspective. London: Taylor and Francis, 1995.

LOESCH, A. The Economics of Location. Revue de Géographie de Lyon, 30 (3), 1955 [1940].

LÓPEZ CUEVILLAS, F. Civilización Céltica en Galicia. Porto, 1953.

LÓPEZ CUEVILLAS, F. La Edad del Hierro en el Noroeste (la cultura dos Castros). Madrid, 1956

LÓPEZ CUEVILLAS, F. Historia de Galiza. Buenos Aires, 1973 (Vol. III).

LÓPEZ ROMERO, R. Cálculo de rutas óptimas mediante SIG en el território de la ciudad celtibérica de Segeda. Propuesta metodológica. SALDVIE, 5, 2005, p. 95111.

LÓPEZ SÁEZ, J. A.; LÓPEZ MERINO, L.; PÉREZ DÍAZ, S. Neolitización, Megalitismo y Antropización del paisaje en Galicia entre el VII y el IV milenio cal. BC. MUNIBE Suplemento - Gehigarria, 32. Donostia/San Sebastián: S.C. Aranzadi. Z.E., p. 488-496, 2010.

LÓPEZ-BARJA DE QUIROGA, P. Sobre la guerra justa. Sémata, 23, p. 61-75, 2011.

LORRIO, A. J. Los Celtíberos. Alicante, 1997.

LYNCH, K. A imagem da cidade. São Paulo: Martins Fontes, 1997.

MAGNIN, L. et al. GIS Modelo of Topographic Accessibility to South America. Late Pleistocene Peopling of Latin America, Southbound, 2012.

MALUQUER DE MOTES; NICOLAU, J. El mundo indígena del Noroeste hispánico antes de la llegada romana. Actas del Coloquio Internacional sobre el Bimilenario de Lugo, 1977.

MALUQUER DE MOTES; NICOLAU, J. La Edad del Bronce en el Occidente Atlántico. $1^{\text {as }}$ Jornadas de Metodología, 1, 1975.

MALUQUER DE MOTES; NICOLAU, J. La España de la Edad de Hierro. In: GÓMEZTABANERA, J. M. (Ed.). Las Raíces de España. Madrid, p. 109-130, 1967.

MANGAS, J. Hispania Romana. In: TUÑÓN DE LARA, M. (Dir.). Historia de España, Vol. I, Barcelona: Labor, 1992.

MANGAS, J. Leyes coloniales y municipales de la Hispania romana. Madrid: Arco Libros, 2001. 
MANTAS, V. Gil. Bracara Augusta e a rede viária augustana do Noroeste Peninsular. In: MORAIS, R.; BANDEIRA, M.; SOUSA, M. J. (Eds.). Celebração do Bimilenário de Augusto: Ad Nationes. Ethnous Kallaikon. Braga: Câmara Municipal de Braga, p. 136-150, 2016.

MANTAS, V. Gil. As estações viárias lusitanas nas fontes itinerárias da antiguidade. Humanitas, 66, p. 231-256, 2014.

MANTAS, V. Gil. Império, Cultura e Romanidade. Romanística - UM, $n^{\circ} 1$, Centro de Estudos Clássicos e Humanísticos da Universidade de Coimbra, p. 9-38, 2013.

MANTAS, V. Gil. Os miliários como fontes históricas e arqueológica. Humanitas, 64, p. 139-169, 2012.

MANTAS, V. Gil. As relações europeias do território português na época romana. In: Estudos Arqueológicos de Oeiras, 15, Oeiras: Câmara Municipal, 2007, p. 183-208.

MARÍN SUÁREZ, C. Astures y Asturianos. Historiografía de la Edad del Hierro en Asturias. Noia: Toxosoutos, 2005 (Serie Keltia; 27).

MARÍN SUÁREZ, C. De nómadas a castreños. Los orígenes de la Edad del Hierro en Asturias. In: MARÍN SUÁREZ, C.; JORDÁ PARDO, J. (eds.). Arqueología castreña en Asturias. Entemu, 16: 19-44, 2009.

MARÍN SUÁREZ, C. De nómadas a castreños: el primer milenio antes de la era en el sector centro-occidental de la cordillera cantábrica. Tesis de la Universidad Complutense de Madrid, Facultad de Geografía e Historia, Departamento de Prehistoria (Doutorado), 2012.

MARTÍNEZ PADILLA, C. Algunas reflexiones sobre espacio y tiempo en Arqueología del Territorio. In: SÁNCHEZ-PALENCIA, F.J. et al. (Eds.). Arqueología, Sociedad, Territorio y Paisaje. Estudios sobre Prehistoria Reciente, Protohistoria y Transición al Mundo Romano. Madrid: Consejo Superior de Investigaciones Científicas Instituto de Historia, p. 11-24, 2010.

MARTINS, C. M. B. A exploração mineira romana e a metalurgia do ouro em Portugal. Dissertação (Doutorado). Porto: Faculdade de Letras da Universidade do Porto, 2005.

MARTINS, C. M. B. A mineração romana no conjunto mineiro Chaves/Boticas/ Montalegre. Revista Aquae Flaviae, 41, Chaves, p. 303-309, 2009.

MARTINS, Manuela. A Arqueologia dos castros no Norte de Portugal: Balanço e perspectivas de investigação. Trabalhos de Antropologia e Etnologia, 28 (34), p. 11-35. Porto: Sociedade Portuguesa de Antropologia e Etnologia, 1988a.

MARTINS, Manuela. A citânia de S.Julião, em Vila Verde: memória dos trabalhos realizados entre 1981-1985. Braga, (Cadernos de Arqueologia, Monografias; 2), $1988 b$

MARTINS, Manuela. O povoamento proto-histórico e a romanização da bacia do curso médio do Cávado. Braga, (Cadernos de Arqueologia, Monografias; 5), 1990. 
MARTINS, Manuela. Continuidade e mudança no I $^{\circ}$ milénio a.C. no Noroeste português: os diferentes cenários de representação do discurso arqueológico. Cadernos de Arqueologia, Série II, 10-11, p. 41-64, 1993.

MARTINS, Manuela. Povoamento e habitat no Noroeste português durante o $1^{\circ}$ milénio a. C. In: De Ulisses a Viriato. O primeiro milénio a.C. Lisboa: Museu Nacional de Arqueologia, p. 118-133, 1996.

MARTINS, Manuela. A urbanização do Noroeste peninsular: o caso de Bracara Augusta. In: Actas da Mesa Redonda. Emergência e desenvolvimento das cidades romanas no Norte da Península Ibérica, Porto: Escola Profissional de Arqueologia, 1999.

MARTINS, Manuela. Urbanismo e arquitectura de Bracara Augusta. Balanço dos contributos da arqueologia urbana. In: Simulacra Romae. Roma y las capitales provinciales del ocidente europeu. Estudios arqueológicos, p. 149-173, 2004.

MARTINS, Manuela. As termas romanas do Alto da Cividade. Um exemplo de arquitectura pública de Bracara Augusta. Braga: UAUM - Unidade de Arqueologia da Universidade do Minho; NARQ - Núcleo de Arqueologia da Universidade do Minho, 2005.

MARTINS, Manuela. A Romanização. In: PEREIRA, P. (Coord). Minho. Traços de Identidade. Braga: Ed. do Conselho Cultural da Universidade do Minho, p. 191269, 2009a.

MARTINS, Manuela. Bracara Augusta: panorama e estado da questão sobre o seu urbanismo. In: DOPICO CAÍNZOS, D.; VILLANUEVA ACUÑA, M.; RODRÍGUEZ ALVAREZ, P. (Eds.). Do Castro á Cidade. A romanización na Gallaecia e na Hispania indoeuropea. Actas do Curso de actualización sobre la romanizaciín de Galiza (2008). Lugo: Servizo de Publicacións da Deputación de Lugo, p. 181211, 2009b.

MARTINS, Manuela; CARVALHO, Helena P. As transformações do território: Bracara Augusta e o seu cadastro. Revista de Historiografía, 25, p. 219-243, 2016.

MARTINS, Manuela; MAR, R.; RIBEIRO, J.; e MAGALHÃES, F. "A Construção do Teatro Romano de Bracara Augusta". In: MELO, A. Sousa e RIBEIRO, M. do Carmo (coord.). História da Construção - Arquitetura e Técnicas Construtivas, Braga: CITCEM - Centro de Investigação Transdisciplinar "Cultura, Espaço e Memória»; LAMOP - Laboratoire de Médiévistique Occidentale de Paris (Université de Paris 1 et CNRS), p. 41-74, 2013.

MARTINS, Manuela; LEMOS, F. S.; PÉREZ LOSADA, F. O povoamento romano no território dos galaicos bracarenses. III Coloquio Internacional de Arqueología en Gijón, Unidad y diversidade en el Arco Atlántico em época romana. Gijón, p. 279-296, 2005.

MARTINS, Manuela; BERNARDES, P. A multi-disciplinary approach for research and presentation of Bracara Augusta's Archaeological Heritage. Archeologia e Calcolatori, 11, p. 347-357, 2000. 
MARTINS, Manuela; DELGADO, M. História e Arqueologia de uma cidade em devir: Bracara Augusta. Cadernos de Arqueologia, 6/7, p. 11-38, 1989-90.

MASSEY, D. Pelo espaço - uma nova política da espacialidade. Rio de Janeiro: Bertrand Brasil, 2008.

MATTINGLY, D. J. (Ed.) Dialogues in Roman imperialism: Power, discourse, and discrepant experience in the Roman Empire. Journal of Roman Archaeology, Supplement 23. London: mar, 1997.

MATTINGLY, D.J. Being Roman: expressing identity in a provincial setting. Journal of Roman Archaeology. Portsmouth RI: The Journal of Roman Archaeology, 17, 2004, p. 5-25.

MATTINGLY, D.J. Imperialism, power and identity: Experiencing the Roman Empire. Princeton: Princeton University Press, 2011.

MCCORMICK, M.; HUANG, G.; GIBSON, K. et al. (ed.), Digital Atlas of Roman and Medieval Civilizations, Harvard University Center for Geographic Analysis. Disponível em: http://darmc.harvard.edu/

MENDES CORREAA, A. Os povos primitivos da Lusitania. Porto, 1974.

MENDES, N. M. Império e Romanização: "estratégias", dominação e colapso. Brathair, São Luís, 7 (1), p. 25-48, 2007b.

MENDES, N. M. O espaço urbano da cidade de Balsa: Uma reflexão sobre o conceito de Romanização. Fênix, Revista de História e Estudos Culturais, 4 (1), Ano IV, Jan./Fev./Mar. 2007a, p. 1-20.

MENDES, N. M. Romanização e a construção da paisagem imperial no sul da Lusitânia. Phoînix, Laboratório de História Antiga/UFRJ, Ano XII, 2006, p. 231256.

MENÉNDEZ BLANCO, A., GONZÁlEZ ÁlVAREZ, D., ÁlVAREZ MARTíNEZ, V.; JIMÉNEZ CHAPARRO, J. I. Nuevas evidencias de la presencia militar romana en el extremo occidental de la Cordillera Cantábrica. Gallaecia, 30, p. 145-165, 2011.

MENÉNDEZ BLANCO, A., GONZÁLEZ, D., COSTA, J. M. A Serra da Casiña (Valboa, León): un campamento romano en las montañas bercianas. Revista Arkeogazte, 5: p. 239-251, 2016.

MENÉNDEZ BLANCO, A., JIMÉNEZ CHAPARRO, J.I., GONZÁLEZ ÁLVAREZ, D.; ÁLVAREZ MARTÍNEZ, V. La conquista romana del Occidente Cantábrico: novedades arqueológicas. In: CASCALHEIRA, J.; GONÇALVES, C. (Eds.). Actas das IV Jornadas de Jovens em Investigação Arqueológica - JIA 2011, Vol. II. Faro: Universidade do Algarve, p. 339-346, 2012 (Promontoria Monográfica; 16).

MENÉNDEZ BLANCO, A.; GONZÁLEZ ÁLVAREZ, D.; ÁLVAREZ MARTÍNEZ, V.; JIMÉNEZ CHAPARRO, J. I. Propuestas de prospección de bajo coste para la detección de campamentos romanos de campaña. El área occidental de la 
Cordillera Cantábrica como caso de estudio. Munibe. Antropologia-Arkeologia, 64, p. 175-197, 2013.

MENÉNDEZ BLANCO, A.; GONZÁLEZ ÁlVAREZ, D.; ÁlVAREZ MARTÍNEZ, V.; JIMÉNEZ CHAPARRO, J. I. Campamentos romanos de campaña en el Occidente de Asturias. In: Excavaciones Arqueológicas en Asturias 20072012. En el centenario del descubrimiento de la caverna de La Peña de Candamo. Oviedo: Consejería de Educación, Cultura y Deporte del Principado de Asturias. Dirección General de Patrimonio Cultural, p. 245-251, 2013.

MENĖNDEZ DE LUARCA, J. R.; SORIA Y PUIG, A. El territorio como artificio cultural. Corografia histórica del Norte de la Península Ibérica. In: Ciudad y Territorio, $\mathrm{n}^{\circ}$ 99, 1994, p. 67-86.

MENĖNDEZ DE LUARCA, J. R.; SORIA Y PUIG, A. (Eds.). A Construção do território: mapa histórico do noroeste da Península Ibérica. Madrid: Lunwerg Editores, 2000.

MIERSE, W. E. Temples and towns in Roman Iberia: the social and architectural dynamics of sanctuary designs from the third century B.C. to the third century A.D. University of California Press, 1999.

MILLET, M. Romanization: historical issues and archaeological interpretation. In: BLAGG, T.; MILLET, M. (Eds.). The Early Roman Empire in the West. Oxford, 1990, p. 33-41.

MOLINA MARÍN, A. I. Geographica: ciencia del espacio y tradición narrativa de Homero a Cosmas Indicopleustes. Antig. crist., Murcia, 27, 2010.

MOMMSEN, Th., Römische Geschichte IV, Berlin: [s.n], 1874.

MORAES, A. C. R. Historicidade, consciência e construção do espaço: notas para um debate. In: AA.VV. A construção do espaço. São Paulo: Ed. Nobel, 1986.

MORAES, A. C. R. Ideologias Geográficas. Espaço, Cultura e Política no Brasil. São Paulo: Annablume, 2005.

MORAIS, J. L. de; MOURÃO, H. A. Inserções do direito na esfera do Patrimônio Arqueológico e Histórico-Cultural. In: WERNECCK et al. (Coords.). Direito ambiental: Temas atuais visto por nós advogados. Belo Horizonte: Del Rey, 2005, p. 341-393.

MORAIS, R.; BANDEIRA, M.; SOUSA, M. J. (Eds.). Celebração do Bimilenário de Augusto: Ad Nationes. Ethnous Kallaikon. Braga: Câmara Municipal de Braga, 2016.

MORALEJO, J. J. Toponimia de las vías romanas de Galicia. Acta Palaeohispanica X, Palaeohispanica, 9, 2009, p. 189-202.

MORENO GALLO, I. Vías romanas de Astorga. In: MORENO GALLO, I. (Coord.) Nuevos Elementos de ingeniería romana. III Congreso de las obras públicas romanas. Astorga: Junta de Castilla y León - Colegio de Ingenieros, p. 23-65, 2006. 
MORENO GALLO, I. Vías Romanas. Ingeniería y técnica constructiva. CEHOPU, Ministerio de Fomento, 2004.

MORENO GALLO, I. Vías Romanas, Ingeniería y Técnica Constructiva. Ministerio de Fomento, Centro de Estudios Históricos de Obras Públicas (CEHOPU), $2^{\mathrm{a}}$ edicíon 2006.

MORILLO CERDÁN, A. Conquista y defensa del territorio en la Hispania republicana: los establecimientos militares temporales. In: MORILLO CERDÁN, A.; CADIOU, F.; HOURCADE, D. (eds.). Defensa y territorio en Hispania de los Escipiones a Augusto (espacios urbanos y rurales, municipales y provinciales). MadridLeón, 2003a, p. 41-80.

MORILLO CERDÁN, Á. Los campamentos romanos de Astorga y León. Espacio, tiempo y forma. Serie II, Historia antigua, $\mathrm{n}^{\circ}$ 16, 2003b, p. 81-112.

MORILLO CERDÁN, Á. Arqueología de la conquista del Norte Peninsular. Nuevas interpretaciones sobre las campañas del 26-25 a.C. In: CADIOU, F.; NAVARRO, M. (Eds.). La Guerre et ses Traces. Conflicts et Sociétés en Hispanie à l'époque de la conquête romaine (III ${ }^{\mathrm{e}} \mathrm{I}^{\mathrm{er}}$ siècle av. J.-C.). Bordeaux: Ausonius, p. 133-148, 2014 (Mémoires; 37).

MORILLO CERDÁN, Á. El territorio galaico durante las Guerras Cántabras: Nuevas perspectivas, In: MORAIS, R.; BANDEIRA, M.; SOUSA, M. J. (Eds.). Celebração do Bimilenário de Augusto: Ad Nationes. Ethnous Kallaikon. Braga: Câmara Municipal de Braga, p. 54-72, 2016.

MOURAZOS GONZÁLEZ, M. J. Mini-Atlas Xeobotánico de Galicia. Xunta de Galicia, Consellería de Educación e Ordenación Universitaria, 2010. Disponível em:

https://www.edu.xunta.es/espazoAbalar/sites/espazoAbalar/files/datos/12876469 65/contido/Miniatlas/xer-relevo.html. Acesso em: 25 set. 2016.

MURGUÍA, M. Galicia. Col. España. Sus monumentos y artes. Su naturaleza é Historia. Barcelona: Establecimiento Tipográfico; Editorial de Daniel Cortezo y C., 1888.

MURRIETA-FLORES, P. Understanding human movement through spatial technologies. The role of natural areas of transit in the Late Prehistory of Southwestern Iberia. Trabajos de Prehistoria, 69 (1), enero-junio 2012, p. 103122.

NÁRDIZ ORTIZ, C. El territorio y los caminos de Galicia. Planos históricos de la red viária. Madrid, 1992.

NÁRDIZ ORTIZ, C. Los puentes romanos de Galicia. Revista de Obras Publicas. Septiembre, 1991, p. 35-62.

NAVEIRO LÓPEZ, J. L. El comercio antiguo en el N.W. peninsular. A Coruña: Museu Arqueológico, 1991 (Monografías Urxentes do Museu n 5). 
NAVEIRO LÓPEZ, J. L. El Golfo Ártabro. Arqueología e Historia del gran puerto de los galaicos lucenses. A Coruña: Asociación Amigos do Museo Arqueolóxico da Coruña, 1994.

NOCETE, F. La formación del estado en las campiñas del alto Guadalquivir (3000-1500 a.n.e.). Servicio de Publicaciones de la Uiniversidad de Granada, 1994.

NOCETE, F. Territorio de coerción: el paradigma de las jefaturas. In: ADÁNEZ, J; HERAS, C M.; VARELA, C. (Eds.). Espacio y organización social. Madrid: Universidad Complutense, 1990, p. 57-90.

NORBERG-SCHULZ, C. Genius Loci, Towards a Phenomenology of Architecture. New York: Rizzoli, 1980.

ÑACO, T. Vectigal incertum. Economía de guerra y fiscalidad republicana en el Occidente romano: su impacto histórico en el territorio (218-133 a.C.). BAR International series, 1158, 2003.

NUNES, J.; FABIÃO, C.; GUERRA, A. O acampamento militar romano da Lomba do Canho (Arganil). Arganil: Museu Regional de Arqueologia, 1988. Disponível em: http://hdl.handle.net/10451/10035

OREJAS SACO DEL VALLE, A. Arqueología del paisaje: de la reflexión a la planificación. Archivo Español de Arqueología, 68 (171-172), 1995, p. 215224.

OREJAS SACO DEL VALLE, A. Arqueología del paisaje: historia, problemas e perspectivas. AEspA, 64, 1991.

OREJAS SACO DEL VALLE, A. El estudio del paisaje: visiones desde la arqueología. Arqueología espacial, 19-20, 1998, p. 9-20.

OREJAS SACO DEL VALLE, A. Investigando el paisaje. A distancia, 1, 2008, p. 7985.

OREJAS SACO DEL VALLE, A. Territorio, análisis territorial y Arqueología del Paisaje. In: Congreso Internacional sobre La Península Ibérica en la Antiguedad. La Imagen de un territorio (Toledo, 1993), 13-14, p. 61-68, 1995-96.

OREJAS SACO DEL VALLE, A.; ÁRBOL MORO, M. R. del; LÓPEZ JIMÉNEZ, O. Los registros del paisaje en la investigación arqueológica. Archivo Español de Arqueología, 75 (185-186), 2002, p. 287-312.

OREJAS SACO DEL VALLE, A.; SÁNCHEZ-PALENCIA, F. J. Mines, Territorial Organization and Social Structure in Roman Iberia: Carthago Nova and the Peninsular Northwest. American Journal of Archaeology, 106, p. 581-599, 2002.

PACHECO RUIZ, R. Re-evaluating Iron Age maritime societies: the North West Iberian Peninsula. Southampton: University of Southampton, 2009. 
PALET MARTÍNEZ, J. P. L'estructuració dels espais agraris en època romana a Catalunya: aportacions de l'estudi arqueomorfològic del territori. Cota Zero, 20, 2005. Vic, p. 53-66. DOSSIER.

PARCERO OUBIÑA, C. Aproximación al espacio social en el mundo castreño. Actas del XXII Congreso Nacional de Arqueología (Vigo, 1993), Vigo, 1995a, p. 185188.

PARCERO OUBIÑA, C. Elementos para el estudio de los paisajes castreños del Noroeste peninsular. Trabajos de Prehistoria, Madrid, 52(1), p. 127-144, 1995b.

PARCERO OUBIÑA, C. Tres para dos. Las formas del poblamiento en la Edad del Hierro del Noroeste Ibérico. Trabajos de Prehistoria, 57-1: 75-95, 2000.

PARCERO OUBIÑA, C. La construcción del paisaje social en la Edad del Hierro del noroeste ibérico. Col. Monografías Ortegalia, $\mathrm{n}^{\circ}$ 1. Ortigueira: Fundación Federico Maciñeira e Instituto de Estudios Galegos Padre Sarmiento, 2002.

PARCERO-OUBIÑA, C.; AYÁN VILA, X.; FÁBREGA ÁlVAREZ, P.; TEIRA BRIÓN, A. Arqueología, paisaje y sociedad. In: GONZÁLEZ GARCÍA, F. J. (Coord.). Los pueblos de la Galicia céltica. Madrid: Akal, p.131-258, 2007.

PARCERO OUBIÑA, C.; CRIADO BOADO, F. \& SANTOS ESTÉVEZ, M. Rewriting landscape: incorporating sacred landscapes into cultural traditions. World Archaeology, 30 (1): p. 159-116, 1998.

PARCERO-OUBIÑA, C.; AYÁN VILA, X. A paisaxe fortificada (800 a.C.-0). In: CRIADO-BOADO, F.; PARCERO OUBIÑA, C.; OTERO VILARIÑO, C.; CABREJAS, E. (Eds.). Atlas Arqueolóxico da Paisaxe Galega. Edicións Xerais de Galicia, p. 189-221, 2016.

PARCERO-OUBIÑA, C.; AYÁN VILA, X.; CRIADO-BOADO, F.; BALLESTEROSARIAS, P. Os cimentos da paisaxe tradicional (cara a nós). In: CRIADO-BOADO, F.; PARCERO OUBIÑA, C.; OTERO VILARIÑO, C.; CABREJAS, E. (Eds.). Atlas Arqueolóxico da Paisaxe Galega. Edicións Xerais de Galicia, p. 225-273, 2016.

PARKER, H. D. The unique qualities of a Geographic Information System: a commentary. Photogrammetic engineering and Remote Sensing, 54 (11), 1988, p. 1547-1549.

PARSONS, J. R. Archaeological Settlement Patterns. Annual Review of Anthropology, 1, p. 127-150, October 1972.

PASSOS, M. M. dos. A Raia divisória: geossistema, paisagem e eco-história. Maringá: Eduem, 2006.

PELEGRÍN CAMPO, J. Polibio, Fabio Píctor y el origen del etnónimo "celtíberos". Gerión 23 (1), p. 115-136, 2005.

PEÑA SANTOS, A. de la. Galicia. Prehistoria, castrexo e primeira romanización. Vigo: A Nosa Terra, 2003. 
PERALTA LABRADOR, E. Los campamentos romanos de campaña ('castra aestiva'): evidencias científicas y carencias académicas. Nivel Cero, 10, Santander, 2002, p. 49-87.

PEREIRA-MENAUT, G. O moderno debate sobre a romanización. In: DOPICO CAÍNZOS, D.; VILLANUEVA ACUÑA, M.; RODRÍGUEZ ALVAREZ, P. (Eds.). Do Castro á Cidade. A romanización na Gallaecia e na Hispania indoeuropea. Actas do Curso de actualización sobre la romanizaciín de Galiza (2008). Lugo: Servizo de Publicacións da Deputación de Lugo, 2009, p. 15-29.

PEREIRA-MENAUT, G. Nueva tabula patronatus del NW de Hispania. Studia Paleohispanica. Actas del IV Coloquio Internacional de Linguas y Culturas Paleohispánicas. Vitoria, 1984, p. 299-303.

PEREIRA-MENAUT, G. (Ed.). Estudos de cultura castrexa e de historia antiga de Galicia. Santiago de Compostela, 1983.

PÉREZ RUBIO, A. Alianzas y coaliciones en la Hispania prerromana. Madrid: Universidad Autónoma de Madrid, 2013.

PÉREZ-ALBERTI, A. et. al. Metodología y clasificación de tipos de paisaje en Galicia. Revista de Geografia e Ordenamento do Território (GOT), 6 (dezembro). Centro de Estudos de Geografia e Ordenamento do Território, p. 259-282, 2014.

PÉREZ LOSADA, F. Os asentamentos na Galicia romana. In: Historia de Galicia (Prehistoria e Historia Antigua), p. 403-41. A Coruña: Ed. Hércules, 1991.

PÉREZ LOSADA, F. Entre a cidade e a aldea. Estudio arqueohistórico dos "aglomerados secundários" romanos en Galicia, (supl. Brigantium, vol. 13). A Coruña, 2002.

PÉREZ losAdA, F.; ACUÑA PIÑEIRO, A. Tude (Tui, Pontevedra): un núcleo secundario na Galicia romana. In: RODRÍGUEZ COLMENERO, A. (coord). Los orígenes de la ciudad en el Noroeste Hispânico, Actas del Congreso Internacional, Lugo, p. 871-890, 1998.

PINA POLO, F. Imperialismo y estrategia militar en la conquista de la Hispania Citerior (218-154 a. C.). In: BURILLO MOZOTA, F. (Ed.). Segeda y su contexto histórico: Entre Catón y Nobilior (195 al 153 a.C.): homenaje a Antonio Beltrán Martínez. Zaragoza: Centro de Estudios Celtibéricos de Segeda, p. 71-80, 2006.

PITILLAS SALAÑER, E. Incidencia de la explotación minera romana sobre tierras del Noroeste Hispánico. Una lectura técnico-económica. Hispania Antigua, Valladolid; Universidad de Valladolid, 24, p. 85-99, 2000.

PITILLAS SALAÑER, E. Integración y promoción social de las poblaciones indígenas del Noroeste Hispánico dentro del esquema organizativo romano: ejército y minería. Memorias de Historia Antiqva, Oviedo, 19-20, p. 225-244, 1998-99.

PRONTERA, F. (Coord.). Tabula Peutingeriana: le antiche vie del mondo. Firenze, 2003.

QUEIROGA, F. M. V. R. War and Castros. Oxford: University of Oxford, 1992. 
RAFFESTIN, C. Por uma Geografia do Poder. São Paulo: Ática, 1993.

RENFREW, C. Before Civilization. The Radiocarbon Revolution and Prehistoric Europe. London: Jonathan Cape, 1975.

RENFREW, C. Megaliths, Territories and Populations. In: LAET, S. J. de (Ed.). Acculturation and Continuity in Atlantic Europe. Brugge: DeTempel, p. 298320, 1976 (Dissertationes Archaeologicae Gandenses; XVI).

RENFREW, C. The Megalithic Builders of Western Europe. In: RENFREW, C. (Ed.). The Megalithic Monuments of Western Europe. Londres: Thames and Hudson, p. 8-17, 1983.

RENFREW, C.; BAHN, P. Arqueología: Teorías, métodos y prácticas. Madrid: Ed. Akal, 1993.

RENFREW, C.; BAHN, P. L'essenziale di archeologia. Teoria, metodi, pratiche. Bologna: Zanichelli Editore, 2009.

REVELL, Louise. Roman Imperialism and Local Identities. Cambridge: Cambridge University Press, 2009.

RIBEIRO, M. do C. A Arqueologia e as Tecnologias de Informação. Uma Proposta para o Tratamento Normalizado do Registo Arqueológico. Dissertação (Mestrado). Universidade do Minho, 2001.

RIBEIRO, O.; LAUTENSACH, H.; DAVEAU, S. A vida económica e social. Lisboa: Edições João Sá da Costa, 1991 (Geografia de Portugal; IV).

RICKLEFS, R. E. A economia da natureza. Rio de Janeiro: Guanabara Koogan, 2003.

RODRÍGueZ ALVAREZ, P. Do Castro á Cidade. Do extrapolítico ao político. In: DOPICO CAÍNZOS, D.; VILLANUEVA ACUÑA, M.; RODRÍGUEZ ALVAREZ, P. (Eds.). Do Castro á Cidade. A romanización na Gallaecia e na Hispania indoeuropea. Actas do Curso de actualización sobre la romanizaciín de Galiza (2008). Lugo: Servizo de Publicacións da Deputación de Lugo, 2009, p. 55-63.

RODRÍGUEZ COLMENERO, A. La red viaria romana del sudeste de Galicia. Valladolid: Secretariado de Publicaciones, Departamento de Historia Antigua, Universidad de Valladolid, 1976.

RODRÍGUEZ COLMENERO, A. Galicia Meridional Romana. Bilbao: Publicaciones de la Universidad de Deusto, 1977.

RODRÍGUEZ COLMENERO, A. Conquista y organización. In: RAMÓN VILLARES (Dir.). Historia de Galicia, Tomo I. Vigo: Editorial Faro de Vigo, 1991.

RODRÍGUEZ COLMENERO, A. et al. Lucus Augusti: Urbs romana. Lugo, 1995a.

RODRÍGUEZ COLMENERO, A. La intervención de la flota romana en la conquista de Gallaecia. In: ALONSO TRONCOSO, Víctor (coord.). Guerra, exploraciones y navegación: del mundo antiguo a la Edad Moderna. A Coruña: Universidade, 1995b, p. 91-99. 
RODRÍGUEZ COLMENERO, A. Mansiones e mutationes en la Via Nova (XVIII del Itinerario de Antonino). Cadernos de Arqueología, Série II, 12-13, 1995-96, p. 89-112.

RODRÍGUEZ COLMENERO, A. La nueva tabula hospitalitatis de la civitas lougeiorum. Problematica y contexto historico. Zeitschrift für Papyrologie und Epigraphik 117, p. 213-226, 1997.

RODRÍGUEZ COLMENERO, A. (Coord.). Lucus Augusti. I. El amañecer de uma ciudad. A Coruña: Fundación Pedro Barrié de la Maza, 1996.

RODRÍGUEZ COLMENERO, A.; FERRER SIERRA, S.; ÁLVAREZ ASOREY, R.D. Miliarios e outras inscricións viarias romanas do noroeste hispânico. Lugo: Consello da Cultura Galega, 2004.

RODRÍGUEZ COLMENERO, A.; ÁLVAREZ ASOREY, R.D. Vía romana XIX. Unha viaxe dende Lugo aos Ancares, seguindo a pegada de Roma Lugo: Deputación Provincial - INLUDES - Concello, 2008.

RODRÍGUEZ MARTÍNEZ, R. M.; ABOAL FERNÁNDEZ, R.; CASTRO HIERRO, V.; CANCELA CEREIJO, C.; AYÁN VILA, X. M. Una posible factoría prerromana en el Noroeste. Primeras valoraciones de la intervención en el Campo de A Lanzada (Sanxenxo, Pontevedra). Férvedes, 6, 2010, p. 159-168.

RODRÍGUEZ MORALES, J. et al. Los clavi caligarii o tachuelas de cáliga: elementos identificadores de las calzadas romanas. Lucentum, 31: 147-164, 2012.

ROLDÁN HERVÁS, J. M. Sobre los acusativos con "ad" en el Itinerario de Antonio. In: Zephyrus: Revista de prehistoria y arqueología, Nº17, p. 109-120, 1966.

ROLDÁN HERVÁS, J. M. Hispania y el ejército romano. Salamanca, 1974.

ROLDÁN HERVÁS, J. M. Itineraria Hispania. Fuentes antiguas para el estudio de las vías romanas de la Península Ibérica. Universidad de Valladolid/ Universidad de Granada, 1975.

ROLDÁN HERVÁS, J. M. Zamora: conquista y integración administrativa. In: De los orígenes al final del medievo. Zamora: Diputación, p. 193-265, 1995 (Historia de Zamora; 1).

ROLDÁN HERVÁS, J. M.; CABALLERO CASADO, C. J. Itinera Hispana: Estudio de las vías romanas en Hispania a partir del Itinerario de Antonio, el Anónimo de Ravena y los Vasos de Vicarello. In: El Nuevo Miliario: boletín sobre vías romanas, historia de los caminos y otros temas de geografía histórica, $\mathrm{N}^{\circ}$. 17, p. 10-253, 2014.

ROMERO MASIÁ, A. A Torre de Hércules dende as súas orixes ata a actualidade. A Coruña: Ayuntamiento de A Coruña; Servicio Municipal de Educación, 1997.

ROMERO MASIÁ, A.; POSE MESURA, X. M. Galicia nos textos clásicos. A Coruña: Museu Arqueológico, 1987 (Monografías Urxentes do Museu n³ 3). 
RUIZ ZAPATERO, G. Historiografía y "Uso Público" de los celtas en la España Franquista. In: WULFF ALONSO, F.; ÁLVAREZ MARTÍ-AGUILAR, M. (Eds.). Antigüedad y Franquismo (1936-1975). Málaga: CEDMA, p. 217-240, 2003.

RUIZ ZAPATERO, G.; BURILLO MOZOTA, F. Metodología para la investigación en arqueología territorial. Munibe, Supl. 6: p. 54-64, 1988.

RUIZ ZAPATERO, G.; LORRIO, A. The prehistoric roots of the Celtiberian World. In: KARL, R.; STIFNER, D. (Eds.). The Celtic World: Celtic Archaeology. Vol. II. London-New York: Routledge, p. 45-67, 2007.

RUIZ, A.; MOLINOS, M. Desde los cazadores-recolectores a los agricultores. In: VV.AA. Historia de Jaén y su provincia. Granada: Ideal, 1996.

RUIZ, A.; MOLINOS, M.; RISQUEZ, C. Paisaje y territorio mundo: dos dimensiones de una misma teoría arqueológica. Arqueología Espacial, 19-20, 1998, p. 21-32.

RUIZ-GÁLVEZ PRIEGO, M. L. Ancient routes and modern motorways: A lasting tradition of communications in the Iberian Peninsula from the Bronze Age onwards. In: ORRLING, C. (Ed.). Symposium Communication in Bronze Age Europe. Transactions of the Bronze Age. Tanumstrand, Bohuslän (Sweden 1995). Sweden: Statens Historiska Museum, p. 81-92, 1999.

SÁEZ TABOADA, B. Aportaciones al trazado de la vía 19 del Itinerario de Antonino a su paso por Galicia. SPAL, 11, p. 389-408, 2002.

SÁEZ TABOADA, B. As vías romanas na Provincia de Lugo. Santiago de Compostela: Lea, 2004.

SÁEZ TABOADA, B. El tramo marítimo de la vía 20 del Itinerario de Antonino. Gallaecia, 20, 2001, p. 249-267.

SALGADO, T. Georeferenciação da Carta Arqueológica do Concelho do Sabugal. Dissertação (Mestrado em Sistemas de Informação Geográfica e Metodologias para a Aquisição de Informação). Universidade Atlântica, Oeiras, 2005.

SALINAS DE FRÍAS, M. Los pueblos prerromanos de la Península lbérica. Madrid: Ediciones Akal S.A, 2007.

SALINAS DE FRÍAS, M. La guerra de los cántabros y astures, la etnografía de España y la propaganda de Augusto. In: HIDALGO DE LA VEGA, M. J.; PÉREZ SÁNCHEZ, D. R.; GERVÁS, M. J. (Eds.). «Romanización» y «Reconquista» en la Península Ibérica: nuevas perspectivas. Salamanca: Universidad de Salamanca, p. 155-170, 1998.

SAMPAIO, A. As vilas do norte de Portugal. Lisboa: Editorial Vega, 1979 (1923).

SAN VICENTE, J. I. La victoria de Décimo Junio Bruto sobre los Galaicos y la retirada de Emilio Lépido de Pallantia: Algunas consideraciones sobre su cronología. Hispania Antiqva, 37-38 (2013-2014), Universidad de Valladolid, p. 41-68, 2014.

SÁNCHEZ MORENO, A.; AGUILERA DURÁN, T. Bárbaros y vencidos, los otros en la conquista romana de Hispania. Notas para una deconstrucción historiográfica. In: CID LÓPEZ, R. M.; GARCÍA FERNÁNDEZ, E. (Eds.). Debita Verba. Estudios en 
homenaje al profesor Julio Mangas Manjarrés. Oviedo: Universidad de Oviedo, 1 , p. 225-244, 2013.

SÁNCHEZ PARDO, J. C. Castros y aldeas galaicorromanas: Sobre la evolución y la transformación del poblamiento indígena en la Galicia romana. Zephyrus, 65, p. 129-148, 2010.

SÁNCHEZ-PALENCIA, F. J. (Ed.). Las Médulas (León). Un paisaje cultural en la Asturia Augustana. León: Instituto Leonés de Cultura, 2001.

SÁNCHEZ-PALENCIA, F. J.; OREJAS SACO DEL VALLE, A. Las Médulas, un paisaje cultural minero. In: AA.VV, Hispania el legado de Roma. Zaragoza: Ministerio de Educación y Cultura, p. 459-461, 1998.

SÁNCHEZ-PALENCIA, F. J.; FERNÁNDEZ-POSSE, M. D., FERNÁNDEZ-MANZANO, J.; OREJAS, A. La Zona Arqueológica de Las Médulas. León. Guía Arqueológica. Ponferrada: Instituto de Estudios Bercianos, 1999.

SÁNCHEZ-PALENCIA, F. J. e MANGAS, J., (coords.) El Edicto del Bierzo. Augusto y el Noroeste de Hispania. Ponferrada, 2000.

SÁNCHEZ-PALENCIA, F. J.; CURRÁS-REFOJOS, B. Campamentos romanos en zonas mineras del cuadrante noroeste de la Península lbérica. In: CAMINOMAYOR, J.; PERALTA-LABRADOR, E.; TORRES-MARTÍNEZ, J. F. (Eds.). Las Guerras Astur-Cántabras. Gijón: KRK Ediciones, p. 273-283, 2015.

SANCHO ROYO, A. En torno al Tratado del Ebro entre Roma y Asdrúbal. Revista Habis, 7, p. 75-110, 1976.

SANTA-OLALLA, M. Esquema paletnológico de la Península. Madri, 1947.

SANTOS YANGUAS, N. Augusto: Conquista y administración del territorio de asturias. Stud. hist., H. ${ }^{a}$ antig., 32, Ediciones Universidad de Salamanca, 2014, p. 153177.

SANTOS YANGUAS, N. De nuevo sobre los Castella: naturaleza, territorio e integración en la Civitas. In: KREMER, D. (Coord.). Onomástica galega II: Onimia e onomástica romana e a situación lingüística do Noroeste Peninsular (17-18 de octubre de 2008). Santiago de Compostela: Servizo de Publicacións e Intercambio Científico da USC, 2009.

SANTOS YANGUAS, N. El final de las guerras asturo-cántabras y la desmilitarización del ejército romano en el territorio de los Astures. Espacio, Tiempo y Forma, 17-18, p. 237-250, 2004.

SANTOS, D. A reinvenção do espaço: Diálogos em torno da construção do significado de uma categoria. São Paulo: Editora UNESP, 2002.

SANTOS, I. D. A Basilica como elemento de urbanização na Gallia Comata no período de dominação romana. Dissertação (Mestrado em Arqueologia). Programa de Pós-Graduação em Arqueologia; Museu de Arqueologia e Etnologia-USP, 2006. 
SANTOS, M. A natureza do espaço: técnica e tempo - razão e emoção. São Paulo: EDUSP, 2002.

SANTOS, M. O dinheiro e o território. GEOgraphia. Revista da Pós-Graduação em Geografia, UFF. Rio de Janeiro, 1, Ano 1, Junho de 1999b, p. 7-13.

SANTOS, M. O Território e o Saber local: algumas categorias de análise. Cadernos IPPUR, Rio de Janeiro, 13 (2), 1999a, p. 15-26.

SANTOS, M. Técnica, espaço, tempo: globalização e meio técnico-científico informacional. 5. ed. São Paulo: EDUSP, 2008.

SAQUET, M. A. A abordagem territorial: considerações sobre a dialética do pensamento e do território. Anais do I Seminário Nacional sobre Múltiplas Territorialidades. ULBRA/UFRGS, Canoas/Rio Grande do Sul, 2004.

SAQUET, M. A. Abordagens e concepções de território. São Paulo: Expressão Popular, 2007.

SASTRE PRATS, I. Formaciones Sociales y Organización Territorial en el Conventus Asturum. Tese. Madrid: Universidad Complutense de Madrid, 1999.

SAUER, O. A morfologia da paisagem. In: CORREAA, R. L.; ROZENDAHL, Z. (Orgs.). Paisagem, Tempo e Cultura. Rio de Janeiro: EDUERJ, p. 12-74, 1998 [1925].

SAVORY, H. Spain and Portugal. Londres, 1968.

SCOPACASA, R. Repensando a romanização: a expansão romana na Itália a partir das fontes historiográficas. In: Revista de História, São Paulo, 172, p. 113-161, jan.-jun., 2015.

SCHAMA, S. Paisagem e Memória. São Paulo: Companhia das Letras, 1996.

SCHIER, R. A. Trajetórias do conceito de paisagem na Geografia. In: R. RA'E GA, Curitiba, 7, p. 79-85, Editora UFPR, 2003.

SEBASTIAN, L.; JUDGE, W. J. Predicting the Past: Correlation, Explanation, and the Use of Archaeological Models. In: SEBASTIAN, L.; JUDGE, W. J. (Eds.). Quantifying the Present and Predicting the Past: Theory, Method and Application of Archaeological Predictive Modelling. Denver: U.S. Department of the Interior, Bureau of Land Management, 1988, p. 1-18.

SEITSONEN, O.; HOULE, J.-L.; BRODERICK, L.G. GIS approaches to past mobility and accessibility. An example from the Bronze Age Khanuy valley, Mongolia. In: LEARY, J. (Ed.). Past Mobilities: Archaeological Approaches to Movement and Mobility. Ashgate Publishing, 2014.

SEVILLANO FUERTES, M. Á. Asturica Augusta. La recuperación del patrimônio arqueológico en un conjunto histórico. In: DOPICO CAÍNZOS, D.; VILLANUEVA ACUÑA, M.; RODRÍGUEZ ALVAREZ, P. (Eds.). Do Castro á Cidade. A romanización na Gallaecia e na Hispania indoeuropea. Actas do Curso de actualización sobre la romanizaciín de Galiza (2008). Lugo: Servizo de Publicacións da Deputación de Lugo, 2009, p. 235-254. 
SEVILLANO FUERTES, A.; VIDAL ENCINAS, J. M. Urbs Magnífica. Una aproximación a la Arqueología de Astúrica Augusta (Astorga, León). Museo Romano (Guía-Catálogo), Astorga, 2002.

SHANKS, M.; TILLEY, C. Archaeology into the 1990s. Norwegian Archaeology Review, 22(1), p. 1-54, 1989.

SIDEBOTTOM, H. Ancient Warfare. Oxford: Oxford University Press, 2004.

SIDEBOTTOM, H. Roman Imperialism: The Changed Outward Trajectory of the Roman Empire. Historia, 54 (3): p. 315-330, 2005.

SILLIĖRES, P. Les Voies de Communication de I'Hispanie Meridionale. Paris, 1990.

SILVA, A. C. F. da. A Cultura Castreja do Noroeste de Portugal. Paços de Ferreira: Câmara Municipal de Paços de Ferreira, 1986.

SILVA, A. F. da. Estratégias materiais e espacialidade: uma Arqueologia da Paisagem do Tropeirismo nos Campos de Cima da Serra/RS. Dissertação (Mestrado). Porto Alegre, Departamento de História da Faculdade de Filosofia e Ciências Humanas da Pontifícia Universidade Católica do Rio Grande do Sul, 2006.

SILVA, B. dos S. Estrabão e as Províncias da Gália e da Ibéria: um estudo sobre $\boldsymbol{A}$ Geografia e o Império Romano. Dissertação (Mestrado em História). São Paulo, Departamento de História da Faculdade de Filosofia, Letras e Ciências Humanas da Universidade de São Paulo, 2013.

SILVA, B. dos S. Romanização e os séculos XX e XXI: A dissolução de um conceito. Mare Nostrum, 2, 2011, p. 57-75.

SILVA, E. C. C. da. O Lácio Proto-Histórico (Séculos X-VI a.c.): Um estudo de mudança cultural. Dissertação (Mestrado em Arqueologia). Programa de PósGraduação em Arqueologia; Museu de Arqueologia e Etnologia-USP, 2003.

SILVA, E. C. C. da. Aplicações de Geotecnologias em Arqueologia: uma revisão bibliográfica. Trabalho de Conclusão de Curso da Pós-graduação em Geoprocessamento, Centro Universitário Senac - Campus Santo Amaro, São Paulo, 2009.

SILVA, E. C. C. da. Transformações culturais e modelos espaciais no estudo da paisagem da romanização em terras valencianas. Anais do XXI Encontro Estadual de História - ANPUH-SP. Campinas, setembro 2012. Disponível em: <http://www.encontro2012.sp.anpuh.org/resources/anais/17/1351523912_ARQUI VO_1342642533_ARQUIVO_ANPUH_TEXTO_FINAL.pdf>. Acesso em: 09 mar. 2014.

SIMÕES, F. L. R. Arqueologia da Paisagem nas dunas holocênicas: 0 estudo de caso do Sítio Cardoso (Lagoa Redonda, Pirambu, SE). Dissertação (Mestrado em Arqueologia). Laranjeiras, Programa de Pós-graduação em Arqueologia da Universidade Federal de Sergipe, 2014. 
SOEIRO, T. Monte Mozinho. Apontamentos sobre a ocupação entre Sousa e Tâmega em época romana. Penafiel, 1984.

SOLANA SÁINZ, J. M.; SAGREDO SAN EUSTAQUIO, L. La red viaria romana en Hispania, siglos I-IV d. C. Valladolid: Universidad de Valladolid, Secretariado de Publicaciones e Intercambio Editorial, 2006.

SOUSA SOARES, T. de. Reflexões sobre a origem e a formação de Portugal. Coimbra: Faculdade de Letras da Universidade de Coimbra, Instituto de Estudos Históricos Doutor António de Vasconcelos, 1962.

STEVENS, C. E. Crassus. In: HAMMOND, N. G. L. \& SCULLARD, H. H. (Ed.). The Oxford Classical Dictionary. Oxford: Oxford University Press, 1970, p. 295.

SYME, R. The conquest of the North-West Spain, Legio VII Gemina. León, 1970.

TEIXEIRA, R. J. C. M. A. De Aquae Flaviae a Chaves. Povoamento e organização do território entre a Antiguidade e a idade Média. Porto: Faculdade de Letras da Universidade do Porto, 1996.

TERRENATO, N. The romanization of Italy: global acculturation or cultural bricolage? In: FORCEY, C.; HAWTHORNE, J.; WITCHER, R. (Eds). Proceedings of the seventh annual Theoretical Roman Archaeology Conference which formed part of the Second International Roman Archaeological Conference, TRAC 97, University of Nottingham. Oxford: Oxbow, p. 20-27, 1998.

THÜNEN, J. H. Von. Der isolirte Staat in Beziehung auf Landwirthschaft und Nationalökonomie. Hamburg: Perthes, 1826 (Disponível em: http://www.deutschestextarchiv.de/book/show/thuenen_staat_1826).

TILLEY, C. A Phenomenology of Landscape. Places, Paths and Monuments. Oxford: Berg Publishers, 1994.

TILLEY, C. The Materiality of Stone: Explorations in Landscape Phenomenology. Oxford: Berg Publishers, 2004.

TORRES LUNA, M. P. de. Recorriendo la depresión meridiana, arteria vital de Galicia. Outeiro, 20, (Ejemplar dedicado a: Ramón María del Valle Inclán. Asamblea General de Caixa Galicia), p. 69-71, 1986.

TORRES LUNA, M. P. de; PAZO LABRADOR, A. J.; SANTOS SOLLA, J. M. Galicia, rexión de contrastes xeográficos. Santiago: Universidad de Compostela, 1990.

TORRES RODRIGUEZ, C. Conquista de Galicia Romana por los romanos antes de las guerras cántabras. Boletín de la Universidad de Santiago de Compostela. Santiago de Compostela, p. 79-112, 1951-1952.

TORRES RODRIGUEZ, C. La Galicia romana. Colección Galicia Histórica, Volume 4. A Coruña: Fundación "Pedro Barrie de la Maza", conde de Fenosa"-IEGPS, 1982.

TOVAR, A. Consideraciones sobre geografía y historia de la España antigua, Cuadernos de la Fundación Pastor, 17, p. 11-50, 1971. 
TOVAR, A. L'inscription du Cabeço das Fráguas (Guarda, Portugal) et la langue des Lusitaniens. Études Celtiques, 9, p. 235-268, 1966-1967.

TOVAR, A. Lingüística y arqueología sobre los pueblos primitivos de España. In: GÓMEZ-TABANERA, J. M. (Ed.) Las raíces de España. Madrid: Instituto Español de Antropología Aplicada, p. 213-251, 1967.

TRANOY, A. La Galice Romaine. Recherches sur le nord-ouest de la Péninsule Ibérique dans l'Antiquité. Paris: Diffusion de Boccard. (Publications du Centre Pierre Paris [E.R.A. 522], 7; Collection de la Maison des Pays Ibériques [G.I.S. 15], 7), 1981.

TRANOY, A. A “Fonte do Ídolo”. Religiões da Lusitânia. Loquuntur Saxa. Lisboa, p. $31-32,2002$.

TRANOY, A.; LE ROUX, P. As necrópoles romanas de Bracara Augusta - Les inscriptions funéraires. Cadernos de Arqueologia, 6-7, p. 183-230, 1989/90.

TRIGGER, B. G. História do Pensamento Arqueológico. São Paulo: Odysseus Editora, 2004.

UNTERMANN, J. Elementos de un atlas antroponímico de la Hispania Antigua. Madri, 1965.

URUEÑA ALONSO, J. Algunos criterios para el análisis del espacio en Hispania durante el Alto Imperio. Hispania Antiqva, 33-34 (2009-2010), 2010, p. 25-42.

VAN LEUSEN, M. Cartographic modelling in a cell-based GIS. In: ANDRESEN, J.; MADSEN, T.; SCOLLAR, I. (Eds.). Computing the Past. Computer Applications and Quantitative Methods in Archaeology. Aarhus: Aarhus University Press, 1993, p. 105-124 (CAA 92).

VAN LEUSEN, M. Line-of-sight and Cost Surface Analysis Using GIS (Chapter 6). In: Pattern to Process: Methodological Investigations into the Formation and Interpretation of Spatial Patterns in Archaeological Landscapes. Unpublished PhD dissertation, Faculty of Arts, University of Groningen, 2002. Disponível em: <http://dissertations.ub.rug.nl/FILES/faculties/arts/2002/p.m.van.leusen/ch6.pdf>. Acesso em 25 set. 2016.

VÁZQUEZ SEIJAS, M. Lugo bajo el Imperio Romano. Lugo: Imp. de la Diputación Provincial, 1939.

VEGA AVELAIRA, T. La participación del ejército romano en la construcción viaria. In: Larouco $n^{\circ} 3$, p. 177-192, 2001.

VEYNE, P. Como se escreve a História. Lisboa: Edições 70, 1971.

VICENTE GONZÁLEZ, J. L. Estudio de la red viaria romana de Hispania mediante tecnologías SIG: Las planimetrías de la $1^{\text {a }}$ edición del mtn 1/50.000 de España, una capa de información imprescindible para el investigador. V ENCUENTRO DE IBERCARTO. Santander (España), 4 y 5 de Octubre de 2012, p. 1-26. 
VICENTE GONZÁLEZ, J. L. Vias romanas del Noroeste Hispano: Génesis, trazado y una nueva metodología para su estudio. Revista Mapping, 22, 160, p. 48-67, julio-agosto 2013.

VITA-FINZI, C.; HIGGS, E. S. Prehistoric economy in the Mount Carmel area of Palestine: Site catchment analysis. Proceedings of the Prehistoric Society, 36, 1970, p. 1-37.

VOORIPS, A. Electronic Information Systems in Archaeology. Some notes and comments. Archeologia e Calcolatori, 9, 1986, p. 251-267.

WALDMAN, M. Todos os caminhos levam a Roma: a Cartografia dos Césares, Tábua Peutinger e os limites do espaço. Geografia, Londrina, 22 (1), p. 59-77, jan/abr, 2013.

WARREN, R. E. Predictive Modelling in Archaeology: a Primer. In: ALLEN, K. M. S.; GREEN, S. W.; ZUBROW, E. B. W (Eds.). Interpreting Space: GIS and Archaeology. London: Taylor \& Francis, 1990, p. 90-111.

WEBER, A. Alfred Weber's Theory of Location of Industries. Chicago: University of Chicago Press, 1957 [1909].

WHEATLEY, D. Cumulative viewshed analysis: A GIS-based method for investigating intervisibility, and its archaeological application. In: LOCK, G. R.; STANČIČ, Z. Archaeology and Geographic Information Systems: A European Perspective. London: Taylor and Francis, 1995, p. 171-185.

WHEATLEY, D. Going over old ground: GIS, archaeological theory and the act of perception. In: ANDRESEN, J.; MADSEN, T.; SCOLLAR, I. (Eds.). Computing the Past: Computer Applications and Quantitative Methods in Archaeology. Aarhus: Aarhus University Press, 1993, p. 133-138 (CAA 92).

WHEATLEY, D.; GILLINGS, M. Spatial Technology and Archaeology: The Archaeological Applications of GIS. London: Taylor and Francis, 2002.

WHEATLEY, D.; GILLINGS, M. Vision, perception and GIS: Developing enriched approaches to the study of archaeological visibility. In: LOCK, G. R. (Ed.). Beyond the Map: Archaeology and Spatial Technologies. Amsterdam: IOS Press, 2000, 1-27 (NATO Science Series A: Life Sciences; 321).

WHITLEY, T. G.; BURNS, G. 2008. Conditional GIS surfaces and their potential for archaeological predictive modelling. In: POSLUSCHNY, A.; LAMBERS, K.; HERZOG, I. (Eds.). Layers of Perception. Proceedings of the $35^{\text {th }}$ International Conference on Computer Applications and Quantitative Methods in Archaeology (CAA). Berlin, Germany, April 2-6, 2007. Bonn: Dr. Rudolf Habelt GmbH (Kolloquien zur Vor- und Frühgeschichte), 10, 2008, p. 292298.

WILLEY, G. R. Prehistoric settlement patterns in the Virù Valley, Peru. Bureau of American Ethnology Bulletin, 155. Washington, DC: Smithsonian Institution, 1953. 
WOOLF, G. Becoming Roman: the origins of provincial civilization in Gaul. Cambridge, 1998.

XAVIER DA SILVA, J. O que é Geoprocessamento? Revista do CREA-RJ, 79, out./nov. 2009.

XUSTO RODRÍGUEZ, M. Territorialidade castrexa e galaico-romana na Galicia suroriental: A Terra de Viana de Bolo. Ourense: Museo Arqueolóxico Provincial, 1993.

YANGUAS, J. S. Las organizaciones indígenas en el norte peninsular y la romanización. In: DOPICO CAÍNZOS, D.; VILLANUEVA ACUÑA, M.; RODRÍGUEZ ALVAREZ, P. (Eds.). Do Castro á Cidade. A romanización na Gallaecia e na Hispania indoeuropea. Actas do Curso de actualización sobre la romanización de Galiza (2008). Lugo: Servizo de Publicacións da Deputación de Lugo, 2009, p. 65-83.

ZARANKIN, A. Paredes que domesticam: Arqueologia da Arquitetura Escolar Capitalista. $O$ caso de Buenos Aires. Campinas: Centro da Arte e Arqueologia - IFCH-UNICAMP, 2002.

ZEDEÑO, M. N. The Archaeology of Territory and Territoriality. In: DAVID, B.; THOMAS, J. (Eds.). The Handbook of Landscape Archaeology. Walnut Creek, California: Left Coast Press, p. 210-217, 2008. 
ANEXOS 
Anexo 1 - Modelo Digital do Terreno: Vias XVII, XVIII e XIX do Itinerário de Antonino 
Anexo 2 - Modelo Digital do Terreno: Cálculo de caminho ótimo das Vias XVII, XVIII e XIX 


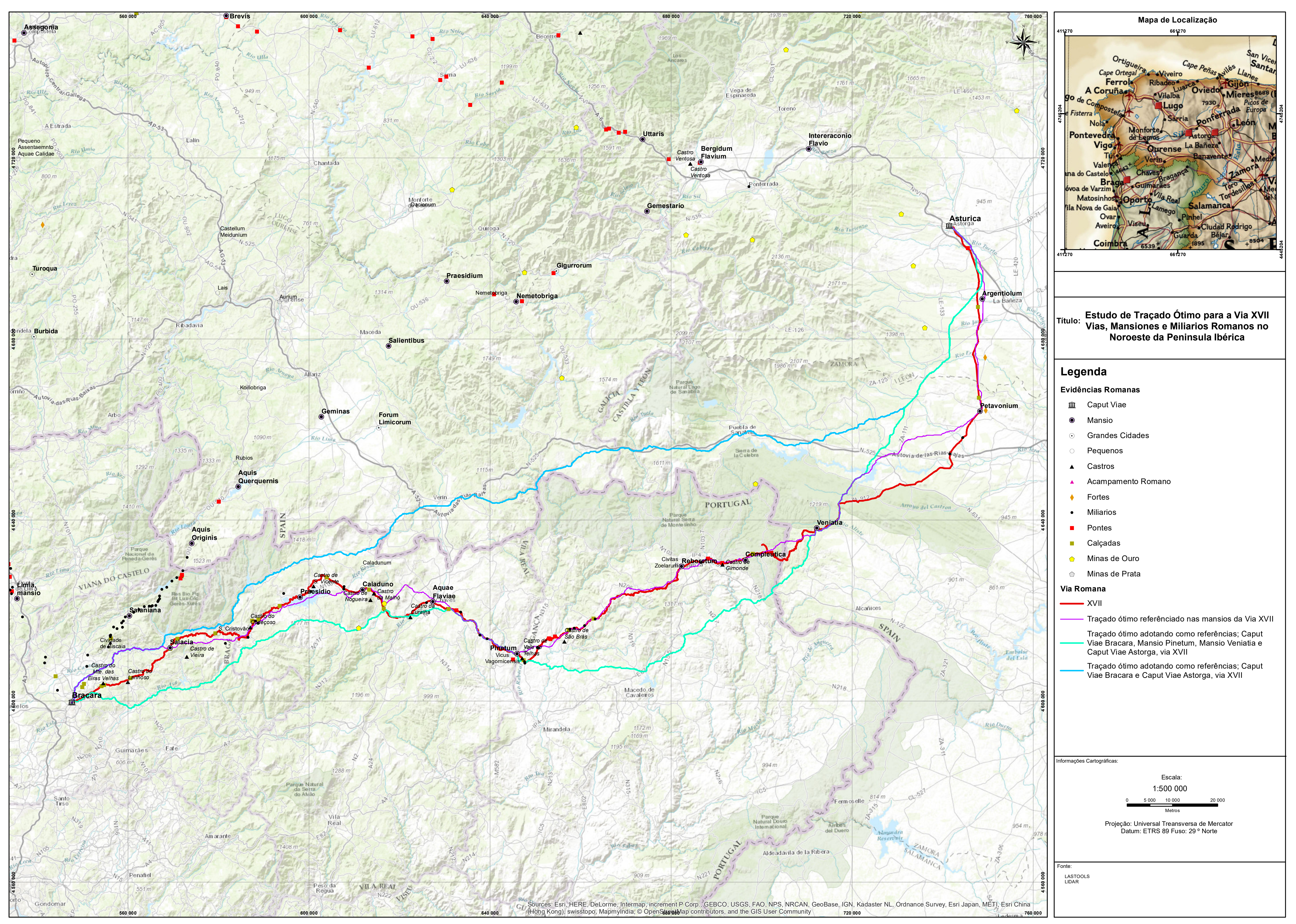




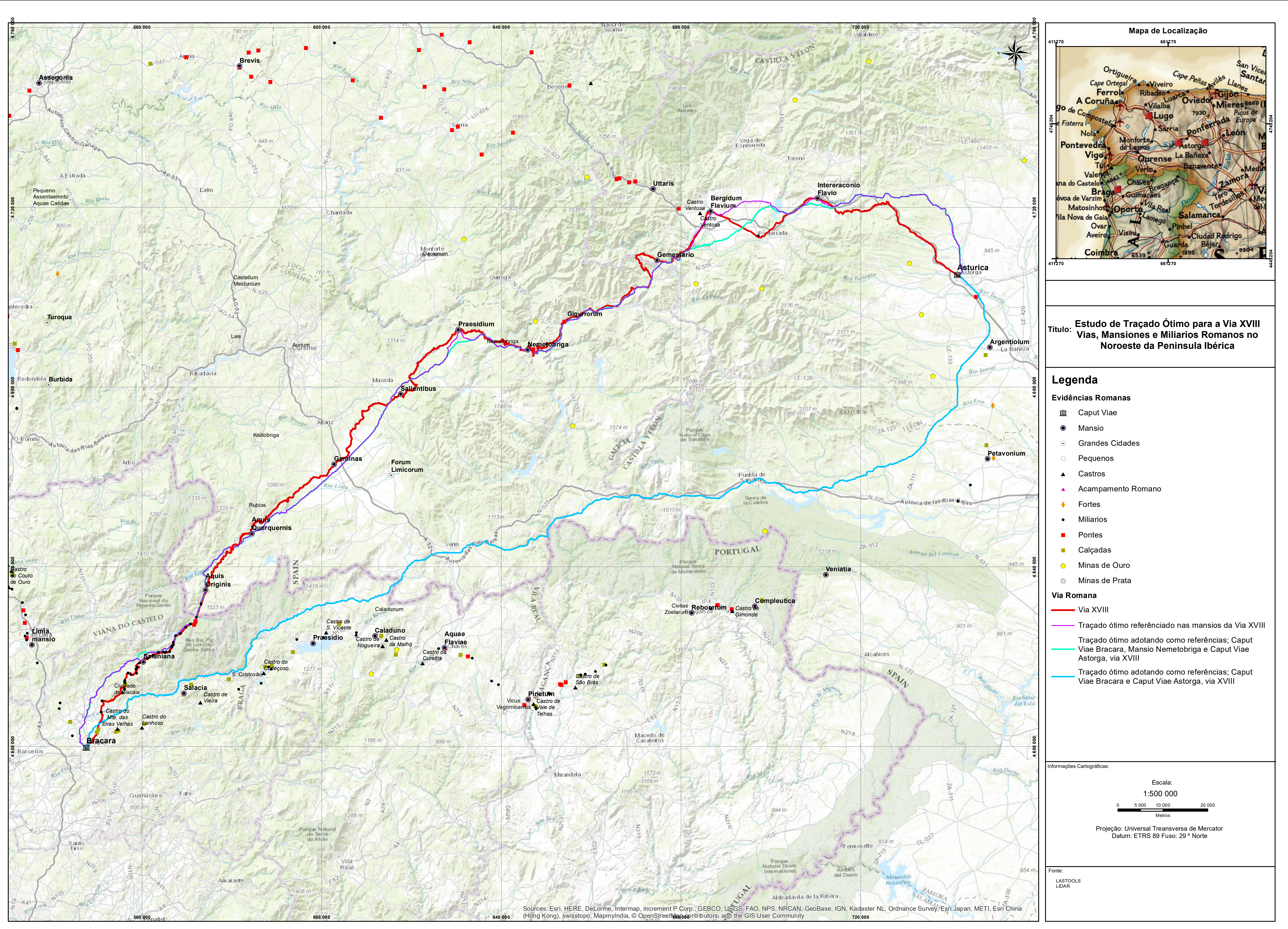




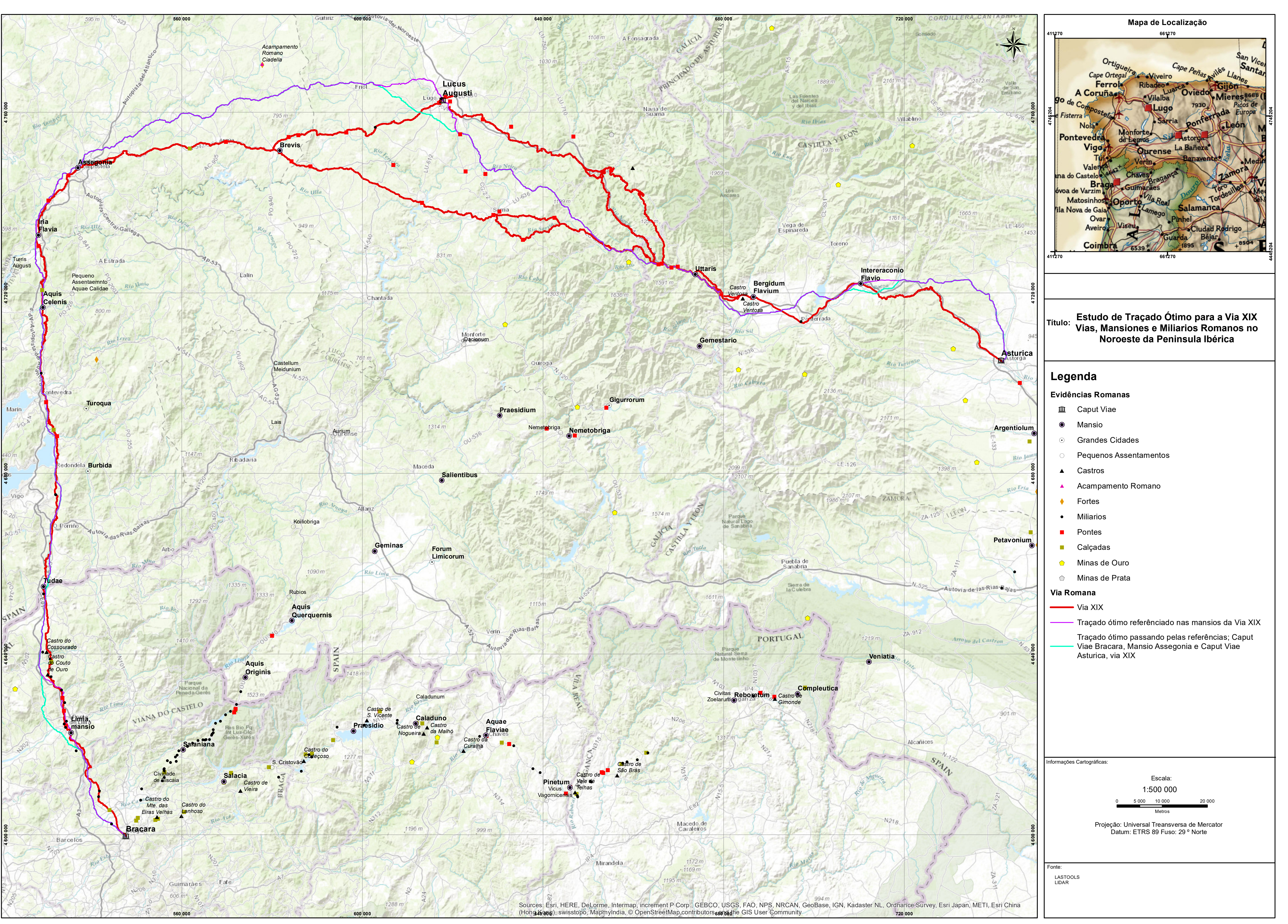

